\title{
Hurricane Sandy Impacts on Coastal Wetland Resilience
}

Open-Fille Report 2018-1142

U.S. Department of the Interior U.S. Geological Survey

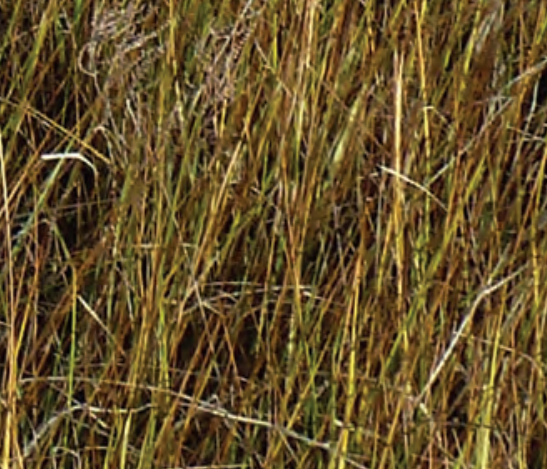


Cover. Salt marsh dominated by Spartina alterniflora at Fire Island National Seashore, Long Island, New York, about two weeks after passage of Hurricane Sandy. Photograph by James Lynch, National Park Service, Northeast Coastal and Barrier Network, Washington, D.C., November 13, 2012. 


\title{
Hurricane Sandy Impacts on Coastal Wetland Resilience
}

By Donald R. Cahoon, Jennifer H. Olker, Alice G. Yeates, Glenn R. Guntenspergen, James B. Grace, Susan C. Adamowicz, Shimon Anisfeld, Andrew H. Baldwin, Nels Barrett, Leah Beckett, Alice Benzecry, Linda K. Blum, David M. Burdick, William Crouch, Marci Cole Ekberg, Sarah Fernald, Kristin Wilson Grimes, Joseph Grzyb, Ellen Kracauer Hartig, Danielle A. Kreeger, Marit Larson, Scott Lerberg, James C. Lynch, Nicole Maher, Martha Maxwell-Doyle, Laura R. Mitchell, Jordan Mora, Victoria O'Neill, Angela Padeletti, Diann Prosser, Tracy Quirk, Kenneth B. Raposa, William G. Reay, Drexel Siok, Christopher Snow, Adam Starke, Lorie Staver, J. Court Stevenson, and Vincent Turner

Open-File Report 2018-1142

\author{
U.S. Department of the Interior \\ U.S. Geological Survey
}




\title{
U.S. Department of the Interior DAVID BERNHARDT, Acting Secretary \\ U.S. Geological Survey James F. Reilly II, Director
}

\author{
U.S. Geological Survey, Reston, Virginia: 2019
}

For more information on the USGS - the Federal source for science about the Earth, its natural and living resources, natural hazards, and the environment-visit https://www.usgs.gov or call 1-888-ASK-USGS (1-888-275-8747).

For an overview of USGS information products, including maps, imagery, and publications, visit https://store.usgs.gov.

Any use of trade, firm, or product names is for descriptive purposes only and does not imply endorsement by the U.S. Government.

Although this information product, for the most part, is in the public domain, it also may contain copyrighted materials as noted in the text. Permission to reproduce copyrighted items must be secured from the copyright owner.

Suggested citation:

Cahoon, D.R., Olker, J.H., Yeates, A.G., Guntenspergen, G.R., Grace, J.B., Adamowicz, S.C., Anisfeld, S., Baldwin, A.H., Barrett, N., Beckett, L., Benzecry, A., Blum, L.K., Burdick, D.M., Crouch, W., Ekberg, M.C., Fernald, S., Grimes, K.W., Grzyb, J., Hartig, E.K., Kreeger, D.A., Larson, M., Lerberg, S., Lynch, J.C., Maher, N., Maxwell-Doyle, M., Mitchell, L.R., Mora, J., O’Neill, V., Padeletti, A., Prosser, D., Quirk, T., Raposa, K.B., Reay, W.G., Siok, D., Snow, C., Starke, A., Staver, L., Stevenson, J.C., and Turner, V., 2019, Hurricane Sandy impacts on coastal wetland resilience: U.S. Geological Survey Open-File Report 2018-1142, 117 p., https://doi.org/10.3133/ofr20181142.

ISSN 2331-1258 (online) 


\section{Acknowledgments}

Requests for individual SET - MH datasets, and associated metadata, used in this report should be made to the authors and their institutions provided in the authors' list [see below] and the people listed in the acknowledgements that provided data but opted not to be an author [see below]. USGS datasets will be available in late 2019 in Science Base https://www.sciencebase.gov/catalog/.

We wish to acknowledge the following people and institutions that provided data in support of this project (names presented alphabetically):

Robert R. Christian, East Carolina University, Greenville, North Carolina

Patricia Delgado, Jug Bay Wetlands Sanctuary, Anne Arundel County, Maryland

Lyndie Dice-Hunton, Delaware Department of Natural Resources and Environmental Control, Delaware Coastal Programs, Dover, Delaware

R. Michael Erwin, U.S. Geological Survey (USGS), Emeritus

Anne Giblin, Hap Garritt, Karen Sundberg, and Samantha Bond of the Plum Island Estuary LongTerm Ecological Research site, Massachusetts (funded by National Science Foundation [NSF] Plum Island Ecosystems - Long Term Ecological Research [PIE-LTER] 1637630 and 1238212)

Lora Harris, University of Maryland Center for Environmental Science, Chesapeake Biological Laboratory, Solomons, Maryland

Kelly Hines Leo, New York Habitat Restoration Coordinator, New England and Interstate Water Pollution Control Commission, New York State Department of Environmental Conservation, Long Island Sound Study, East Setauket, New York

Patrick Megonigal, Adam Langley, and Thomas Mozdzer of the Smithsonian Global Change Research Wetland [funded by the NSF- Long Term Research in Environmental Biology [LTREB] Program (DEB-1557009), Department of Energy-Terrestrial Ecosystem Science [TES] Program (DE-FG02-97ER62458), USGS (G10AC00675), and the Smithsonian Institution].

Geoffrey Sanders, National Park Service, Washington, D.C.

R. Scott Warren, Connecticut College, New London, Connecticut

Patricia Wiberg, University of Virginia, Charlottesville, Virginia

U.S. Fish and Wildlife Service staff in the northeast United States, including

Nathan Bush, U.S. Fish and Wildlife Service, Northeast Regional Office, Hadley, Massachusetts Paul Castelli, Edwin B. Forsythe National Wildlife Refuge, Oceanville, New Jersey John Gallegos and Geralynn Mireles, Back Bay National Wildlife Refuge, Virginia Beach, Virginia Ben Gaspar, Rhode Island National Wildlife Refuge Complex, Charlestown, Rhode Island

Curt Kessler and Monica Williams, Long Island National Wildlife Refuge Complex, Shirley, New York 
We wish to acknowledge the following organizations for their funding and logistical support:

Shimon Anisfeld thanks the U.S. Environmental Protection Agency and Connecticut Sea Grant for funding to install and monitor surface elevation table (SET) stations.

Andrew Baldwin — Work was funded by a grant from the Department of Energy's National Institute for Climatic Change Research awarded to Andrew Baldwin (P.I.), Michael Kearney, David Tilley, and Jeffrey Cornwell; award number TUL-543-06/07.

Alice Benzecry gratefully acknowledges the support of Fairleigh Dickinson University and Meadowlands Environmental Research Institute (MERI) for funding to install and monitor SET stations. http://meri.njmeadowlands.gov/projects/sea-level-rise-measurements/.

Linda Blum - SET and marker horizon (MH) data collection is based upon work supported by the NSF under Grants No. BSR-8702333-06, DEB-9211772, DEB-9411974, DEB-0080381, DEB0621014 and DEB-1237733. The Virginia Coast Reserve of the Nature Conservancy provided access to study sites. Database citation for this dataset is Blum and others (2017).

David Burdick gratefully acknowledges the support of Great Bay National Estuarine Research Reserve (NERR) and Wells NERR, the New Hampshire Coastal Program of the New Hampshire Department of Environmental Services, and National Oceanic and Atmospheric Administration (NOAA), Coastal Zone Management (CZM).

Marci Cole Ekberg - The Save the Bay SET stations in Rhode Island were funded by a grant from the NOAA Restoration Center.

Sarah Fernald - SET stations in the Tivoli Bays were installed with NOAA funding from the Hudson River National Estuarine Research Reserve Operations Grant \#16, NOAA grant NA07NOS4200118.

Kristin Grimes - SET stations at Wells NERR funded by NOAA NA14NOS4200036.

Nicole Maher - The Nature Conservancy in New York acknowledges the generous financial support for this work from the Zegar Family Foundation and the Pritchard Charitable Trust.

Angela Padeletti-Partnership for the Delaware Estuary (http://www.delawareestuary.org/ science-and-research/wetlands/): Mid-Atlantic Coastal Wetland Assessment, Site Specific Intensive Monitoring Database: Surface Elevation Tables \& Marker Horizons [2011-16]. Previous and continued data collection supported by U.S. EPA Region 2; U.S. EPA Region 3; U.S. EPA HQ; DNREC Wetland Assessment; Barnegat Bay Partnership; New Jersey Coastal Zone. Kenneth Raposa - Financial support was provided in part by a grant under the Federal Coastal Zone Management Act, administered by the Office of Ocean and Coastal Management, NOAA, Silver Spring, Maryland.

William Reay-Maintenance and monitoring of Chesapeake Bay National Estuarine Research Reserve (CBNERR) SET-MH stations are supported, in part, by NERR operational awards from the Office of Ocean and Coastal Management, NOAA.

Lorie Staver-Financial support was provided by the Maryland Port Authority, Port of Baltimore; and the Maryland Environmental Service.

We wish to acknowledge the following people for assistance in field data collection and management, and in report preparation:

Jessie Buckner, Barnegat Bay Partnership, Toms River, N.J., assisted in data management and collection. Melanie Mills, Academy of Natural Sciences, Philadelphia, Pa., assisted in data collection and management. We thank Kristi Nixon, Natural Resources Research Institute, University of Minnesota Duluth, for GIS assistance. Ellen Kracauer Hartig thanks New York City Parks 
partners Rebecca Boger of Brooklyn College, City University of New York (CUNY), for providing funding for installing additional stations and Alice Benzecry of Fairleigh Dickinson University and her students who assisted with monitoring. Jenny Allen and Amanda Garzio-Hadzick assisted in the field at the Chesapeake Bay National Estuarine Research Reserve in Maryland. We thank Toni Mikula and Kate O'Brien at Rachel Carson National Wildlife Refuge (NWR), and Curtis George at Bombay Hook NWR for their support. Shimon Anisfeld thanks Troy Hill for assistance in monitoring SET-MH stations. In New England, Roelof Boumans, Larry Ward, and Chris Peter assisted in field work. Shannon Beliew, U.S. Geological Survey, Patuxent Wildlife Research Center, updated the map figures for publication. 


\section{Contents}

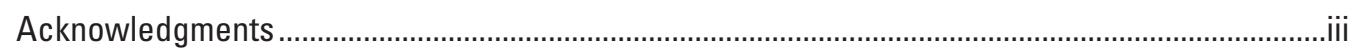

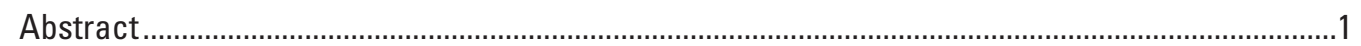

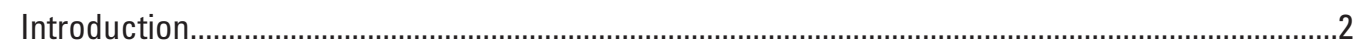

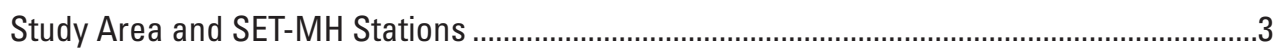

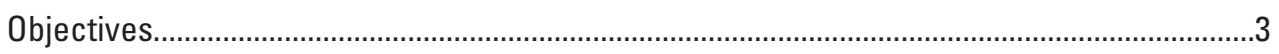

Inventory and Distribution of SET-MH Stations Along the Atlantic Coast........................................

Data Formatting and Analyses...............................................................................................

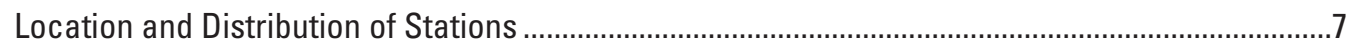

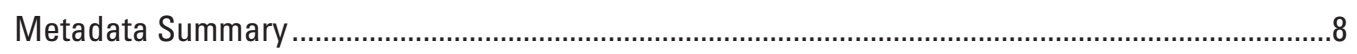

Hurricane Sandy Effects on Coastal Marsh Elevation Change .........................................................

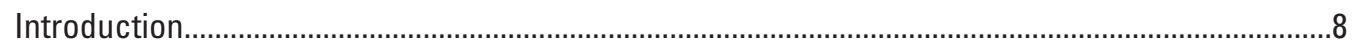

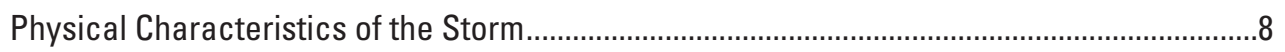

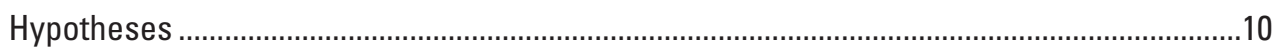

Methods

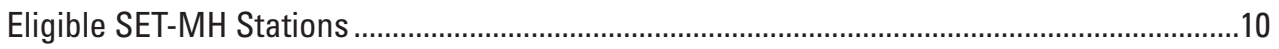

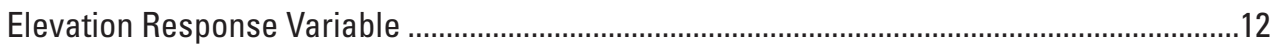

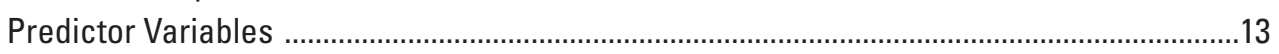

Variables Representing Storm Exposure and Intensity ......................................................13

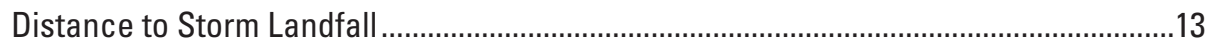

Exposure to Storm Surge (Within or Outside Surge Zone) ............................................13

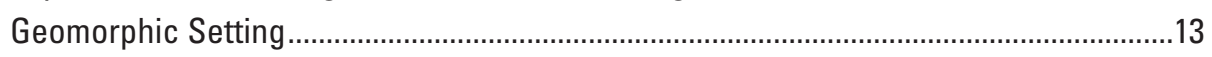

Position Relative to Storm Landfall .........................................................................13

Additional Variables to Account for Unexplained Variance .....................................................14

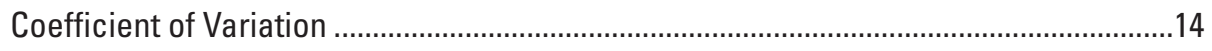

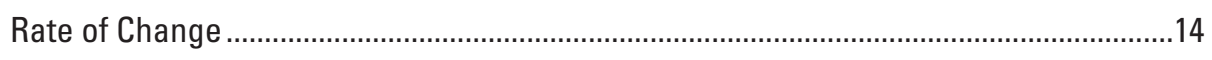

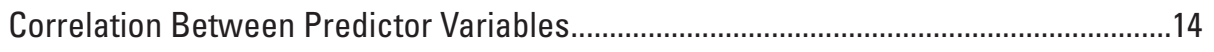

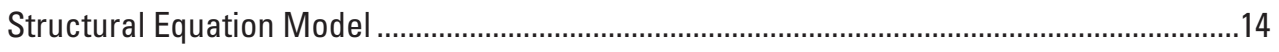

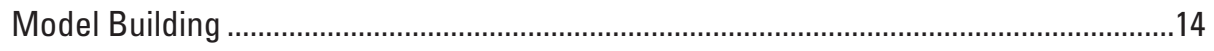

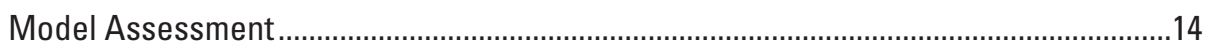

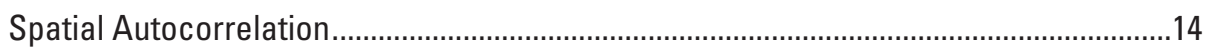

Statistical Programs and Packages Used .........................................................................16

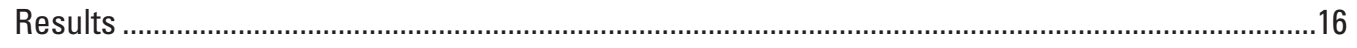

Correlation Between Predictor Variables.......................................................................16

Distribution of SET-MH Stations Used in Effects Analysis.....................................................16

Deviation from Expected Surface Elevation Change Model ...................................................16

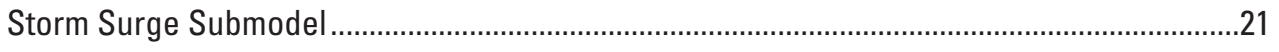

Structural Equation Model Selected for Interpretation ........................................................24

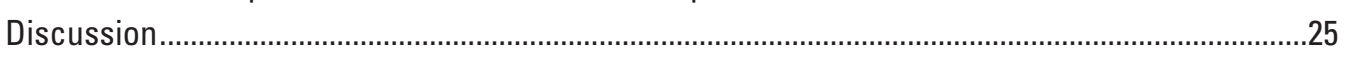

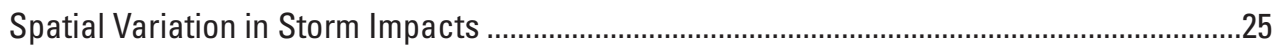

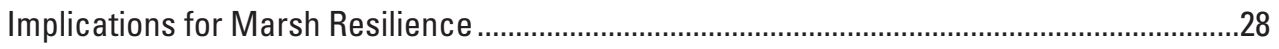

Factors to Consider in Development of a Strategic Monitoring Framework ..................................29

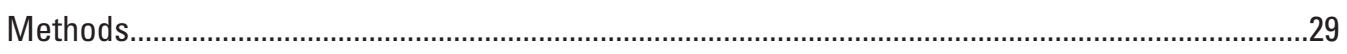

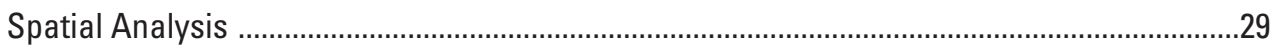


Incorporating Risk—Data Sources and Application ....................................................................30

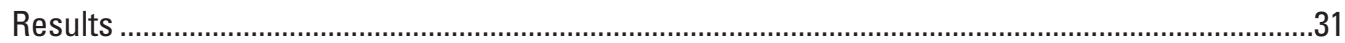

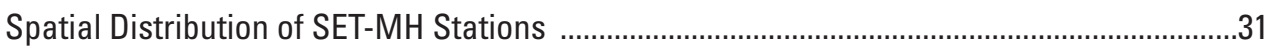

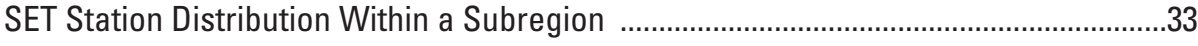

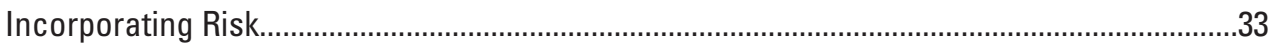

Risk of Hurricane Strikes and Storm Surge by Subregion .............................................34

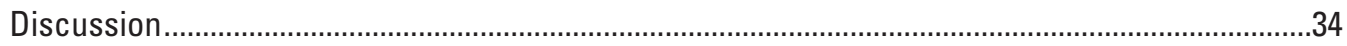

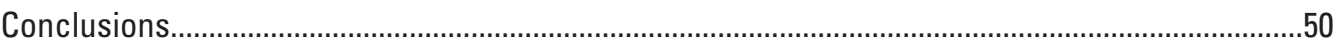

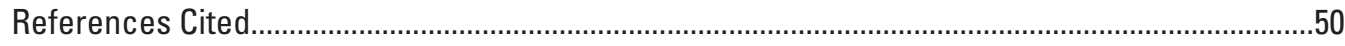

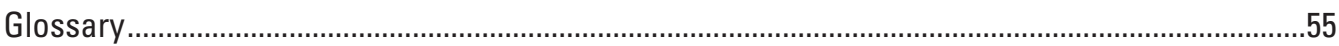

Appendix 1. The Surface Elevation Table-Marker Horizon Method ............................................59

Appendix 2. SET-MH Metadata Spreadsheet.......................................................................63

Appendix 3. Best Model Summaries ..........................................................................................117

\section{Figures}

1. A, Map showing Hurricane Sandy track and intensity, as well as locations of moored National Oceanic and Atmospheric Administration (NOAA) National Data Buoy Center buoys recording wave height and period. $B$, Nighttime image of Hurricane Sandy captured 16-18 hours before landfall by the Visible Infrared Imaging Radiometer Suite on the National Aeronautics and Space Administration (NASA)/NOAA Suomi National Polar-orbiting Partnership satellite, a composite of several satellite passes. C, NASA Aqua satellite image of Hurricane Sandy, October 29, 2012, 2:20 p.m. EDT

2. Map of study region between Maine and Virginia (inclusive) indicating 10 subregions and the general locations of surface elevation table-marker horizon station clusters.

3. Preferred Reporting Items for Systemic Reviews and Meta-Analyses flow diagram detailing the omission of surface elevation table-marker horizon records from the inventory and the Hurricane Sandy effects analysis.

4. Schematic diagram of initial structural equation model illustrating the hypothetical pathways between predictor variables and response variables

5. Graph showing mean surface elevation change from July 2005 to September 2013 at the U.S. Geological Survey Blackwater 7D.1 surface elevation table (Cambridge, $\mathrm{Md})$.

6. Graph showing frequency distribution of number of days between Hurricane Sandy (October 30, 2012) and the poststorm surface elevation table measurement for each eligible station

7. Graphs showing bivariate relations between predictor variables in the eligible total surface elevation dataset.

8. Maps of study region showing storm track, wind swaths, and stations with eligible surface elevation table data in each category: $A$, position relative to landfall, $B$, geomorphic setting, and $C$, storm surge.

9. Graph of model prediction versus response for the best deviation from expected surface elevation model (15e)

10. Graph of poststorm deviation from expected surface elevation change along the distance to storm landfall gradient 
11. Graphs showing frequency distribution of $A$, poststorm residual distance from expected and $B$, prestorm mean residual distance using all eligible surface elevation table data

12. Graphs showing frequency distribution of poststorm residual distance from expected for eligible surface elevation table stations to the $A$, left and $B$, right of landfall

13. Graph showing storm surge presence or absence along the distance from landfall gradient.

14. Graphs showing frequency distribution of poststorm residual distance from expected for eligible surface elevation table stations with storm surge $A$, present and $B$, absent.

15. Schematic diagram of revised surface elevation model ...........................................27

16. Map of study region between Maine and Virginia (inclusive) indicating area of estuarine emergent marsh per hexagon (40 square kilometers or 4,000 hectares)........30

17. Maps of study region between Maine and Virginia (inclusive) indicating $A$, number of surface elevation table-marker horizon (SET-MH) stations per hexagon (40 square kilometers or 4,000 hectares [ha]), and $B$, number of SETs per 1,000 ha estuarine emergent marsh in each hexagon.

18. Map of dominant broad geomorphic setting of marsh patches (estuarine emergent marsh) in each hexagon (40 square kilometers) across the study region (Virginia to Maine, inclusive).

19. Maps showing percent of estuarine emergent marsh patch area by broad geomorphic settings in each hexagon (40 square kilometers) across several subregions with mixed geomorphic settings (Long Island, southern New England, and Cape Cod/Casco Bay), with $A$, percent estuarine marsh, and $B$, percent back-barrier lagoon.

20. Maps of study region between Maine and Virginia (inclusive) indicating $A$, the number of surface elevation table-marker horizon (SET-MH) stations owned by Federal agencies per hexagon (40 square kilometers), 664 SETs in 107 hexagons; and $B$, hexagons with publicly owned marsh (by states, National Park Service, or U.S. Fish and Wildlife Service).

21. Map showing hurricane return period (based on National Hurricane Center hurricane strike dataset from 1900-2009 for U.S. coastal counties) for the study region (Virginia to Maine, inclusive) with hexagon (40 square kilometers) sampling grid and hexagons with surface elevation table-marker horizon stations indicated......38

22. Map showing predicted worst-case scenario storm surge footprints by hurricane storm strength, from the Federal Emergency Management Agency Coastal Flood Loss Atlas SLOSH (Sea, Lake, and Overland Surges from Hurricanes) model maximum of maximums for the study region (Virginia to Maine, inclusive) with hexagon (40 square kilometers) sampling grid and hexagons with surface elevation table-marker horizon stations indicated.

23. Map showing northern portion of study area predicted worst-case scenario storm surge footprints by hurricane storm strength, from the Federal Emergency Management Agency Coastal Flood Loss Atlas SLOSH (Sea, Lake, and Overland Surges from Hurricanes) model maximum of maximums for Cape Cod/Casco Bay and coastal Maine subregions with hexagon (40 square kilometers) sampling grid and hexagons with surface elevation table-marker horizon stations indicated. 
24. Map showing central portion of study area predicted worst-case scenario storm surge footprints by hurricane storm strength, from the Federal Emergency Management Agency Coastal Flood Loss Atlas SLOSH (Sea, Lake, and Overland Surges from Hurricanes) model maximum of maximums for Cape Cod/Casco Bay, southern New England, Long Island, and part of coastal New Jersey subregions with hexagon (40 square kilometers) sampling grid and hexagons with surface elevation table-marker horizon stations indicated

25. Map showing southern portion of study area predicted worst-case scenario storm surge footprints by hurricane storm strength, from the Federal Emergency Management Agency Coastal Flood Loss Atlas SLOSH (Sea, Lake, and Overland Surges from Hurricanes) model maximum of maximums for coastal Virginia, eastern and western Chesapeake Bay, coastal Delmarva, Delaware Bay, and coastal New Jersey subregions with hexagon (40 square kilometers) sampling grid and hexagons with surface elevation table-marker horizon stations indic ated...

26. Map showing coastal Maine subregion predicted worst-case scenario storm surge footprints by hurricane storm strength, from the Federal Emergency Management Agency Coastal Flood Loss Atlas SLOSH (Sea, Lake, and Overland Surges from Hurricanes) model maximum of maximums with hexagon (40 square kilometers) sampling grid and hexagons with surface elevation table-marker horizon stations indicated...

27. Map showing Cape Cod/Casco Bay subregion (and neighboring areas) predicted worst-case scenario storm surge footprints by hurricane storm strength, from the Federal Emergency Management Agency Coastal Flood Loss Atlas SLOSH (Sea, Lake, and Overland Surges from Hurricanes) model maximum of maximums with hexagon (40 square kilometers) sampling grid and hexagons with surface elevation table-marker horizon stations indicated.

28. Map showing southern New England subregion (and neighboring areas) predicted worst-case scenario storm surge footprints by hurricane storm strength, from the Federal Emergency Management Agency Coastal Flood Loss Atlas SLOSH (Sea, Lake, and Overland Surges from Hurricanes) model maximum of maximums with hexagon (40 square kilometers) sampling grid and hexagons with surface elevation table-marker horizon stations indicated.

29. Map showing Long Island subregion (and neighboring areas) predicted worst-case scenario storm surge footprints by hurricane storm strength, from the Federal Emergency Management Agency Coastal Flood Loss Atlas SLOSH (Sea, Lake, and Overland Surges from Hurricanes) model maximum of maximums with hexagon (40 square kilometers) sampling grid and hexagons with surface elevation table-marker horizon stations indicated

30. Map showing coastal New Jersey subregion (and neighboring areas) predicted worst-case scenario storm surge footprints by hurricane storm strength, from the Federal Emergency Management Agency Coastal Flood Loss Atlas SLOSH (Sea, Lake, and Overland Surges from Hurricanes) model maximum of maximums with hexagon (40 square kilometers) sampling grid and hexagons with surface elevation table-marker horizon stations indicated.

31. Map showing Delaware Bay subregion (and neighboring areas) predicted worst-case scenario storm surge footprints by hurricane storm strength, from the Federal Emergency Management Agency Coastal Flood Loss Atlas SLOSH (Sea, Lake, and Overland Surges from Hurricanes) model maximum of maximums with hexagon (40 square kilometers) sampling grid and hexagons with surface elevation table-marker horizon stations indicated. 
32. Map showing coastal Virginia and eastern/western Chesapeake Bay subregions (and neighboring areas) predicted worst-case scenario storm surge footprints by hurricane storm strength, from the Federal Emergency Management Agency Coastal Flood Loss Atlas SLOSH (Sea, Lake, and Overland Surges from Hurricanes) model maximum of maximums with hexagon (40 square kilometers) sampling grid and hexagons with surface elevation table-marker horizon stations indicated

\section{Tables}

1. Geomorphic settings of coastal wetlands in the mid-Atlantic coast of the United States

2. Subregion names and boundaries.

3. Five hypothetical examples of surface elevation table survey times and exclusion of data from analyses based on season of prestorm and poststorm measurements.

4. Number of surface elevation table stations used in analyses and distance to storm landfall (minimum, maximum, and range) for each unique geomorphic and geographic location category

5. Models used to determine deviation from expected surface elevation change, measured as the residual distance of poststorm elevation change

6. Storm surge submodels

7. Results from variance inflation factor analysis assessing the colinearity between predictor variables in the deviation from expected surface elevation model and the storm surge submodel

8. Comparing distance from storm landfall curves (linear and quadratic) in the deviation from expected surface elevation model and storm surge submodel using Akaike's Information Criterion, AICc

9. Deviation from expected surface elevation change models ranked by corrected Akaike's Information Criteria (AICc)

10. Effective sample sizes for all top models.

11. Summary information for stations with a deviation from expected elevation change greater than \pm 5 millimeters

12. Storm surge models ranked by corrected Akaike's Information Criteria (AICC)

13. Summary of the spatial distribution of surface elevation table-marker horizon (SET-MH) stations, hexagons (with estuarine emergent marsh [E2EM]), hexagons (with E2EM marsh) with SET-MH stations, mean minimum distance between hexagons with SETs, and Global Moran's I (measure of clustering) across 10 subregions between Maine and Virginia (inclusive)

14. Summary of the spatial distribution of estuarine emergent marsh patches and surface elevation table-marker horizon stations within marsh patches among 10 subregions between Maine and Virginia (inclusive)

15. Summary of the spatial distribution of surface elevation table-marker horizon stations, estuarine emergent marsh patches, and geomorphic settings among 10 subregions between Maine and Virginia (inclusive) 


\section{Conversion Factors}

U.S. customary units to International System of Units

\begin{tabular}{|c|c|c|}
\hline Multiply & By & To obtain \\
\hline \multicolumn{3}{|c|}{ Length } \\
\hline inch (in.) & 2.54 & centimeter $(\mathrm{cm})$ \\
\hline inch (in.) & 25.4 & millimeter (mm) \\
\hline foot $(\mathrm{ft})$ & 0.3048 & $\operatorname{meter}(\mathrm{m})$ \\
\hline mile (mi) & 1.609 & kilometer $(\mathrm{km})$ \\
\hline yard $(y d)$ & 0.9144 & meter $(\mathrm{m})$ \\
\hline \multicolumn{3}{|c|}{ Area } \\
\hline acre & 4,047 & square meter $\left(\mathrm{m}^{2}\right)$ \\
\hline acre & 0.4047 & hectare (ha) \\
\hline acre & 0.4047 & square hectometer $\left(\mathrm{hm}^{2}\right)$ \\
\hline acre & 0.004047 & square kilometer $\left(\mathrm{km}^{2}\right)$ \\
\hline square foot $\left(\mathrm{ft}^{2}\right)$ & 929.0 & square centimeter $\left(\mathrm{cm}^{2}\right)$ \\
\hline square foot $\left(\mathrm{ft}^{2}\right)$ & 0.09290 & square meter $\left(\mathrm{m}^{2}\right)$ \\
\hline square inch $\left(\mathrm{in}^{2}\right)$ & 6.452 & square centimeter $\left(\mathrm{cm}^{2}\right)$ \\
\hline $\begin{array}{l}\text { section (640 acres or } \\
1 \text { square mile) }\end{array}$ & 259.0 & square hectometer $\left(\mathrm{hm}^{2}\right)$ \\
\hline square mile $\left(\mathrm{mi}^{2}\right)$ & 259.0 & hectare (ha) \\
\hline square mile $\left(\mathrm{mi}^{2}\right)$ & 2.590 & square kilometer $\left(\mathrm{km}^{2}\right)$ \\
\hline \multicolumn{3}{|c|}{ Flow rate } \\
\hline foot per second $(\mathrm{ft} / \mathrm{s})$ & 0.3048 & meter per second $(\mathrm{m} / \mathrm{s})$ \\
\hline foot per minute $(\mathrm{ft} / \mathrm{min})$ & 0.3048 & meter per minute $(\mathrm{m} / \mathrm{min})$ \\
\hline foot per hour $(\mathrm{ft} / \mathrm{h})$ & 0.3048 & meter per hour $(\mathrm{m} / \mathrm{h})$ \\
\hline foot per day (ft/d) & 0.3048 & meter per day $(\mathrm{m} / \mathrm{d})$ \\
\hline foot per year (ft/yr) & 0.3048 & meter per year $(\mathrm{m} / \mathrm{yr})$ \\
\hline cubic foot per second $\left(\mathrm{ft}^{3} / \mathrm{s}\right)$ & 0.02832 & cubic meter per second $\left(\mathrm{m}^{3} / \mathrm{s}\right)$ \\
\hline $\begin{array}{l}\text { cubic foot per second } \\
\text { per square mile } \\
\left(\left[\mathrm{ft}^{3} / \mathrm{s}\right] / \mathrm{mi}^{2}\right)\end{array}$ & 0.01093 & $\begin{array}{l}\text { cubic meter per second } \\
\text { per square kilometer } \\
\left(\left[\mathrm{m}^{3} / \mathrm{s}\right] / \mathrm{km}^{2}\right)\end{array}$ \\
\hline cubic foot per day $\left(\mathrm{ft}^{3} / \mathrm{d}\right)$ & 0.02832 & cubic meter per day $\left(\mathrm{m}^{3} / \mathrm{d}\right)$ \\
\hline inch per hour (in/h) & 0.0254 & meter per hour $(\mathrm{m} / \mathrm{h})$ \\
\hline inch per year (in/yr) & 25.4 & millimeter per year $(\mathrm{mm} / \mathrm{yr})$ \\
\hline mile per hour (mi/h) & 1.609 & kilometer per hour $(\mathrm{km} / \mathrm{h})$ \\
\hline knot (1 nautical mi/h) & 1.151 & mile per hour $(\mathrm{mi} / \mathrm{h})$ \\
\hline \multicolumn{3}{|c|}{ Pressure } \\
\hline atmosphere, standard (atm) & 101.3 & kilopascal (kPa) \\
\hline bar & 100 & kilopascal (kPa) \\
\hline
\end{tabular}

Temperature in degrees Celsius $\left({ }^{\circ} \mathrm{C}\right)$ may be converted to degrees Fahrenheit $\left({ }^{\circ} \mathrm{F}\right)$ as follows: ${ }^{\circ} \mathrm{F}=\left(1.8 \times{ }^{\circ} \mathrm{C}\right)+32$.

Temperature in degrees Fahrenheit $\left({ }^{\circ} \mathrm{F}\right)$ may be converted to degrees Celsius $\left({ }^{\circ} \mathrm{C}\right)$ as follows: ${ }^{\circ} \mathrm{C}=\left({ }^{\circ} \mathrm{F}-32\right) / 1.8$. 


\section{Abbreviations}

$\begin{array}{ll}\text { AIC } & \text { Akaike's Information Criterion } \\ \text { FEMA } & \text { Federal Emergency Management Agency } \\ \text { NOAA } & \text { National Oceanic and Atmospheric Administration } \\ \text { NWI } & \text { National Wetlands Inventory } \\ \text { NWR } & \text { National Wildlife Refuge } \\ \text { SET-MH } & \text { surface elevation table-marker horizon } \\ \text { USGS } & \text { U.S. Geological Survey }\end{array}$




\title{
Hurricane Sandy Impacts on Coastal Wetland Resilience
}

\author{
By Donald R. Cahoon', Jennifer H. Olker², Alice G. Yeates², Glenn R. Guntenspergen', James B. Grace', Susan \\ C. Adamowicz ${ }^{3}$, Shimon Anisfeld ${ }^{4}$, Andrew H. Baldwin ${ }^{5}$, Nels Barrett ${ }^{6}$, Leah Beckett ${ }^{5}$, Alice Benzecry ${ }^{7}$, Linda \\ K. Blum ${ }^{8}$, David M. Burdick ${ }^{9}$, William Crouch ${ }^{10}$, Marci Cole Ekberg ${ }^{11}$, Sarah Fernald ${ }^{12}$, Kristin Wilson Grimes ${ }^{13}$, \\ Joseph Grzyb ${ }^{14}$, Ellen Kracauer Hartig ${ }^{15}$, Danielle A. Kreeger ${ }^{16}$, Marit Larson ${ }^{15}$, Scott Lerberg ${ }^{17}$, James C. \\ Lynch $^{18}$, Nicole Maher ${ }^{19}$, Martha Maxwell-Doyle ${ }^{20}$, Laura R. Mitchell ${ }^{21}$, Jordan Mora ${ }^{22}$, Victoria O'Neill ${ }^{23}$, \\ Angela Padeletti ${ }^{16}$, Diann Prosser ${ }^{1}$, Tracy Quirk ${ }^{24}$, Kenneth B. Raposa ${ }^{25}$, William G. Reay ${ }^{17}$, Drexel Siok ${ }^{26}$, \\ Christopher Snow ${ }^{27}$, Adam Starke ${ }^{19}$, Lorie Staver ${ }^{28}$, J. Court Stevenson ${ }^{28}$, and Vincent Turner ${ }^{29}$
}

\section{Abstract}

The goal of this research was to evaluate the impacts of Hurricane Sandy on surface elevation trends in estuarine marshes located across the northeast region of the United States from Virginia to Maine using data from an opportunistic (in other words, not strategic) and collaborative network (from here on, an opportunistic network) of surface elevation tablemarker horizon (SET-MH) stations. First, we built a database of metadata for 965 individual stations from 96 unique geographical locations that included the location, geomorphic setting, and wetland type for each SET-MH station. The dominant estuarine settings included in the analyses were

\footnotetext{
${ }^{1}$ U.S. Geological Survey.

${ }^{2}$ University of Minnesota, Duluth, Minn.

${ }^{3}$ U.S. Fish \& Wildlife Service, Rachel Carson National Wildlife Refuge, Wells, Maine.

${ }^{4}$ Yale University, School of Forestry \& Environmental Studies, New Haven, Conn.

${ }^{5}$ University of Maryland, College Park, Md.

${ }^{6}$ Natural Resources Conservation Service, Amherst, Mass.

${ }^{7}$ Fairleigh Dickinson University, Teaneck, N.J.

${ }^{8}$ University of Virginia, Charlottesville, Va.

${ }^{9}$ Jackson Estuarine Laboratory, University of New Hampshire, Durham, N.H.

${ }^{10}$ U.S. Fish and Wildlife Service, Eastern Virginia Rivers National Wildlife Refuge Complex, Warsaw, Va.

${ }^{11}$ Save the Bay, Narragansett, R.I.

${ }^{12} \mathrm{New}$ York State, Department of Environmental Conservation, Hudson River National Estuarine Research Reserve, Staatsburg, N.Y.

${ }^{13}$ Wells National Estuarine Research Reserve, Wells, Maine; Center for Marine and Environmental Studies, University of the Virgin Islands, St. Thomas, V.I

${ }^{14}$ Meadowlands Environmental Research Institute, Lyndhurst, N.J.

${ }^{15}$ New York City Department of Parks \& Recreation, New York, N.Y.
}

back-barrier lagoonal marshes and emergent marshes along embayments and tidal tributaries. We then calculated prestorm elevation trends to compare to poststorm elevation measurements to determine the storm impact on each station trend. We hypothesized that the effect of Hurricane Sandy on marsh elevation trends would differ by position relative to landfall (right or left) and distance from landfall in southern New Jersey, as both of these variables influence the presence or absence of storm surge as a result of the physical characteristics of tropical cyclones (in other words, strongest winds typically occur to the right of landfall). Storm surge was spatially less extensive and less deep $(\sim 1$ meter $[\mathrm{m}])$ in marshes located to the left (in other words, south) of landfall compared to marshes

\footnotetext{
${ }^{16}$ Partnership for the Delaware Estuary, Wilmington, Del.

${ }^{17}$ Chesapeake Bay National Estuarine Research Reserve, Gloucester Point, Va.

${ }^{18}$ National Park Service, Northeast Coastal and Barrier Network, Washington, D.C.

${ }^{19}$ The Nature Conservancy, Cold Spring Harbor, N.Y.

${ }^{20}$ Barnegat Bay Partnership, Toms River, N.J.

${ }^{21}$ U.S. Fish and Wildlife Service Northeast Region, Bombay Hook National Wildlife Refuge, Smyrna, Del.

${ }^{22}$ Waquoit Bay National Estuarine Research Reserve, Waquoit, Mass.

${ }^{23}$ New England and Interstate Water Pollution Control Commission, New York State Department of Environmental Conservation, Long Island Sound Study, East Setauket, N.Y.

${ }^{24}$ Academy of Natural Sciences of Drexel University, Philadelphia, Pa.

${ }^{25}$ Narragansett Bay National Estuarine Research Reserve, Prudence Island, R.I.

${ }^{26}$ Delaware Department of Natural Resources and Environmental Control, Delaware Coastal Programs, Dover, Del.

${ }^{27}$ Chesapeake Bay National Estuarine Research Reserve in Maryland, Maryland Department of Natural Resources, Annapolis, Md.

${ }^{28}$ University of Maryland Center for Environmental Science, Horn Point Laboratory, Cambridge, Md.

${ }^{29}$ Edwin B. Forsythe National Wildlife Refuge, Oceanville, N.J.
} 
located to the right (in other words, north) of landfall where storm surge covered a larger area and was deeper (3-4 m). About 63 percent of 223 eligible stations had a poststorm trend that was similar to the prestorm trend (in other words, less than \pm 5 millimeters [mm]), indicating little storm impact on elevation trends at those sites. The remaining 37 percent of stations exhibited significant poststorm deviations from the prestorm trend (in other words, greater than $\pm 5 \mathrm{~mm}$ ). Of these, stations located to the left of landfall had a significant and greater deviation in their elevation trend, and the deviation was more likely to be positive (elevation gain) compared to marshes located to the right of landfall, which had a significant deviation in their elevation trend that was more likely to be negative (elevation loss). This finding is directly related to storm surge impacts on marsh sediment deposition, where deep storm surge (3-4 m) results in sediment deposition in habitats inland of coastal marshes but less so in the marshes themselves. Substrate compaction by the storm surge overburden may have contributed to elevation loss, but this was not measured because sufficient marker horizon data were not available for analysis. In contrast, to the left of landfall the wind-driven flooding of sediment laden water pushed into the headwaters of rivers and small bays with an $\sim 1 \mathrm{~m}$ surge, and resulted in more prevalent sediment deposition on the marsh surfaces and elevation gain. In general, the findings support previous research showing that the physical characteristics of the storm (for example, wind speed, storm surge height, impact angle of landfall) combined with the local wetland conditions (for example, marsh productivity, groundwater level, tide height) are important factors determining a storm's impact on soil elevation, and that the soil elevation response can vary widely among multiple wetland sites impacted by the same storm and among different storms for the same wetland site.

The final objective of this project was to create a framework using metadata from the opportunistic network of SETMH stations that could be used to develop a strategic monitoring network designed to address specific climate change impacts and related phenomena identified by land managers and stakeholders. We evaluated the spatial distribution and density of SET-MH stations in relation to geographic coverage, marsh setting, availability of public land, and historical storm surge footprints and hurricane return intervals in order to identify gaps in our understanding of risk and our ability to assess it. Analyses revealed that the general geographic coverage of SET-MH stations is limited given the low percentage of marsh patches with stations, low density of stations, the clumped distribution of stations, and the often limited and uneven distribution of stations in wetlands with a high historical frequency of hurricane strikes and storm surge impacts. These findings can be used by managers and planners to inform the creation of a strategic monitoring network that can, in turn, inform management and adaptation plans for coastal resources in the region. Final plan designs will need to consider financial and infrastructural support required for station maintenance, as well as data collection and management over the long term.

\section{Introduction}

On October 29, 2012, Hurricane Sandy made landfall as a large $(1,611$ kilometers $[\mathrm{km}]$ diameter) post-tropical cyclone near Brigantine, New Jersey, with maximum sustained winds of 130 kilometers per hour $(\mathrm{km} / \mathrm{h})(70$ knots $[\mathrm{kn}])$ and minimum pressure of 94.5 kilopascals $(\mathrm{kPa})$ (945 millibars $[\mathrm{mb}]$; Blake and others, 2013). The storm affected, in varying degrees, the entire Atlantic seaboard of the United States from Florida to Maine (Blake and others, 2013; Valle-Levinson and others, 2013). Understanding the ecological and physical impacts of hurricanes on coastal wetlands and their interaction with local conditions is important for identifying resilience of these marsh communities. In light of the projected increase in the frequency of intense storms and in storm intensity (Knutson and others, 2010; Bender and others, 2010; Peduzzi and others, 2012; Emanuel, 2013; Horton and others, 2011, 2014), the physical (for example, storm surge, sediment deposition) and chemical (for example, salinity, pollutants) impacts associated with hurricanes need to be understood to efficiently and effectively protect and restore these critical habitats. Some of the potential long-term impacts of low-frequency, highmagnitude storm events such as Hurricane Sandy on marsh surface elevation include sediment deposition and erosion, storm surge-related soil compaction, and altered community dynamics, which includes mortality of existing vegetation or promotion of growth through increased availability of nutrients from newly deposited sediment (Cahoon and others, 1995a; Cahoon, 2006). Death of wetland vegetation can lead to loss of elevation by increased root zone decomposition and erosion, whereas increased root growth can lead to elevation gain by root zone expansion (Cahoon and others, 2003). The goal of this study was to evaluate Hurricane Sandy's shortterm impacts on marsh surface elevations within 1 year after the storm.

To assess the impacts of Hurricane Sandy on marsh surface elevation dynamics, we evaluated elevation and accretion data collected with the surface elevation table-marker horizon (SET-MH) method (Cahoon and others, 1995a) throughout marshes of the northeastern region of the United States both before and after the storm. The SET-MH method directly measures both surface elevation change (SET) and vertical accretion $(\mathrm{MH})$. These two measurements can be used to calculate subsurface process influences on elevation change, namely shallow subsidence or shallow expansion (for example, root zone expansion from enhanced root growth; Cahoon and others, 1995b, 2002a,b; Callaway and others, 2013). A more detailed description of the SET device and the marker horizon method, including photographs and a diagram, is provided in appendix 1. Previous research using the SETMH method has shown that hurricanes are powerful agents of geomorphic change (Cahoon, 2006), resulting in both positive and negative changes in elevation trajectories through impacts on both the surface and subsurface soil processes controlling marsh surface elevation. The physical characteristics of the storm (for example, wind speed, storm surge height, impact 
angle of landfall) combined with the local wetland conditions (for example, marsh productivity, groundwater level, elevation relative to the tide, tide height) are important factors determining a storm's impact on marsh soil elevation. In addition, the soil elevation response can vary widely among multiple wetland sites impacted by the same storm and among different storms for the same wetland site (Cahoon, 2006). Thus, findings should not be extrapolated from one wetland to another for any given storm, or from one storm to another for any given wetland. However, using a large number of SET-MH stations across a large geographic area that spans a variety of wetland settings, as well as storm exposures, and intensities can improve our understanding of wetland vulnerability to severe storm effects on marsh surface elevation change.

\section{Study Area and SET-MH Stations}

The study area includes estuarine tidal wetlands along the northeastern coast of the United States from Virginia to Maine, an area that spans the track of the storm as it turned north towards the U.S. coast (fig. 1) and includes the areas of greatest storm surge impacts. High-resolution wetland surface elevation change and accretion data were collected from Virginia to Maine (fig. 2), both before and after the storm, using the SET-MH method. These SET-MH stations were installed during the past two decades independently by the U.S. Geological Survey (USGS), a number of other Federal and nonFederal agencies, nongovernmental organizations (NGOs), and academic institutions to investigate or monitor elevation dynamics in coastal wetlands. The SET-MH method originally consisted of an SET device attached to a pipe benchmark driven 3-6 meters (m) into the substrate (appendix 1, fig. 1.1; Cahoon and others, 2002a) and typically was used to address hypothesis-driven research questions. Later, the Rod SET with deep and shallow benchmarks (10-25 $\mathrm{m}$ and $<1 \mathrm{~m}$, respectively) was developed to provide greater flexibility in addressing research questions (appendix 1, fig. 1.1; Cahoon and others, 2002b). Although the SET-MH method continues to be used to address research questions, over time it has been used increasingly to monitor long-term elevation change relative to local sea-level trends, especially in National parks and wildlife refuges. Overall, 60 percent of SET stations in the northeastregion inventory were located on Federal lands. Hence, SET stations are located in wetlands best suited to address specific research questions or monitor the habitat sustainability at a specific wetland. Thus, the collection of stations represents an opportunistic regional network, not a strategically planned regional network, to assess storm impacts. Nevertheless, data from this opportunistic network enabled large spatial-scale assessments of storm impacts and wetland responses along a gradient of impact intensity by quantifying the overall change in marsh surface elevation.

\section{Objectives}

The objectives of this project were to

1. Build a database of metadata for SET-MH stations in the coastal wetlands of the northeastern United States, including location, geomorphic setting, and wetland type;

2. Analyze elevation and accretion data and related environmental data collected from within the path of Hurricane Sandy to assess coastal wetland responses to this storm;

3. Use assessments of coastal wetland responses to estimate the impact of Hurricane Sandy on marsh sustainability and the potential impact of similar future storms; and

4. Use the database to develop a framework that could support the development of a strategic monitoring network of SET-MH stations in the northeastern United States to assess impacts of storms on coastal wetlands.

\section{Inventory and Distribution of SET-MH Stations Along the Atlantic Coast}

The initial step in this project was to collate known surface elevation table-marker horizon (SET-MH) stations in the northeastern United States by contacting and requesting information from organizations and scientists working in the area. Important activities included (1) contacting all investigators to collect poststorm elevation (SET) and accretion (MH) data, which were gathered in marshes throughout the northeastern region in the weeks and months immediately following the storm; and (2) developing a preliminary spreadsheet to collect metadata (for example, location, setting, wetland type, and so forth) and sending it to each network investigator to fill out.

In the first months of this project, the SET-MH metadata spreadsheet developed immediately following the storm was updated to match a similar SET-MH spreadsheet developed by the National Oceanic and Atmospheric Administration (NOAA) for its Sentinel Site Cooperatives and the North- and South Atlantic Landscape Conservation Cooperatives. In this way, SET-MH metadata will be available in the same format for the entire east coast of the United States, parts of the U.S. gulf coast, and the five pilot sites in NOAA's Sentinel Site Cooperative to assist in development of plans for a strategic SET-MH network for these parts of the country. The updated spreadsheet was distributed to SET colleagues in the northeastern United States. Significant efforts were made to ensure that all known SET practitioners and SET-MH stations were included in the requests for information. These data were collated into an inventory of SET-MH stations along the Atlantic coast from Virginia to Maine inclusive (objective 1). Additionally, metadata were submitted for several stations from NOAA 
$\boldsymbol{A}$

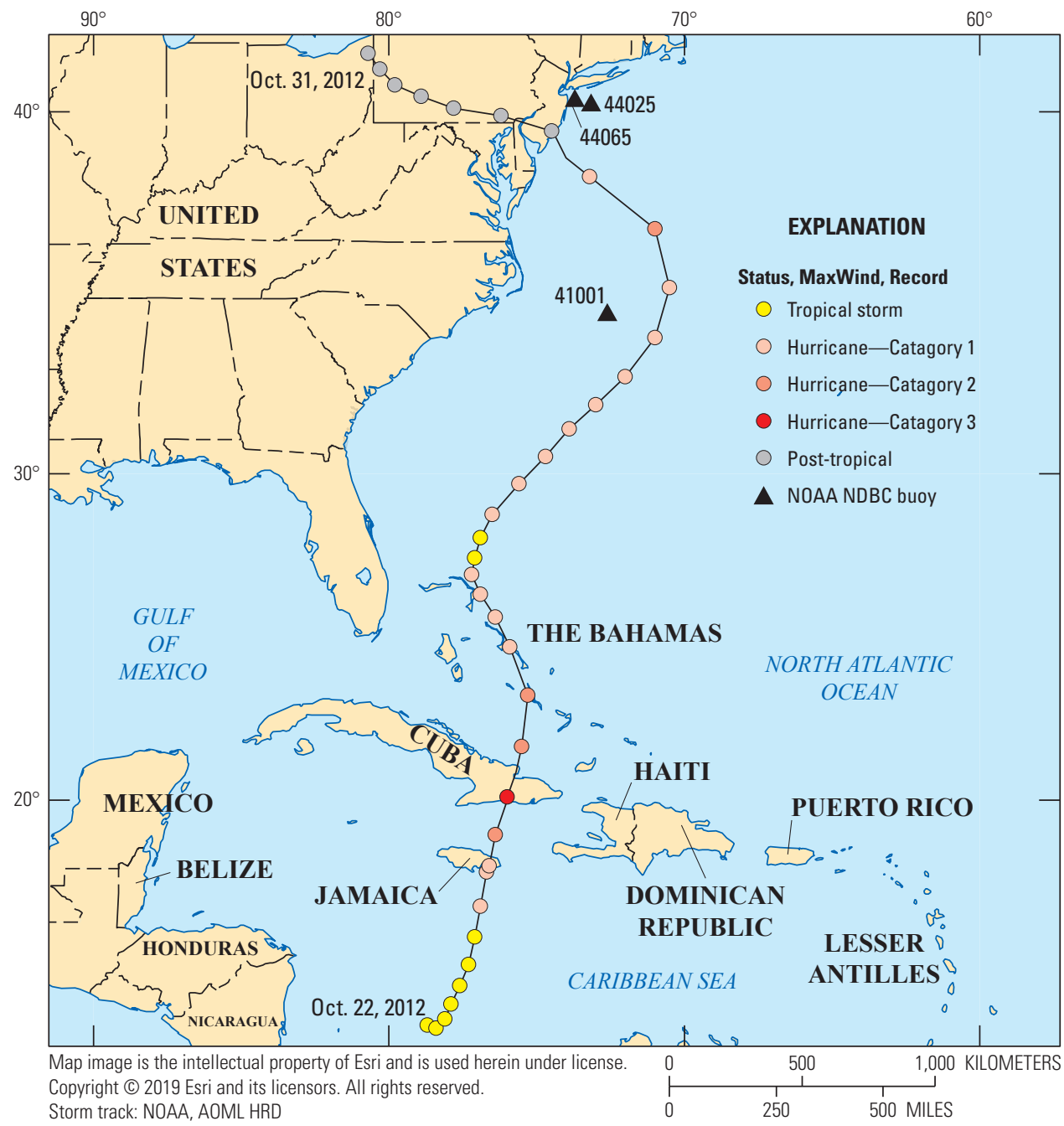

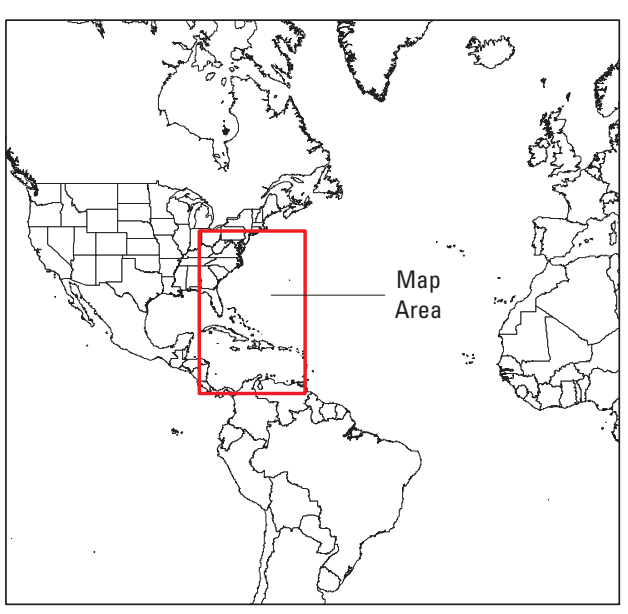

Figure 1. A, Hurricane Sandy track and intensity, as well as locations of moored National Oceanic and Atmospheric Administration (NOAA) National Data Buoy Center (NDBC) buoys recording wave height and period (adapted from Sopkin and others, 2014). B, Nighttime image of Hurricane Sandy captured 16-18 hours before landfall by the Visible Infrared Imaging Radiometer Suite (VIIRS) on the National Aeronautics and Space Administration (NASA)/NOAA Suomi National Polar-orbiting Partnership satellite, a composite of several satellite passes (image provided by University of Wisconsin-Madison). C, NASA Aqua satellite image of Hurricane Sandy, 0ctober 29, 2012, 2:20 p.m. EDT (NASA, 2013; both images accessed at https://www.nasa.gov/mission_pages/hurricanes/archives/2012/h2012_Sandy.html\#11). 

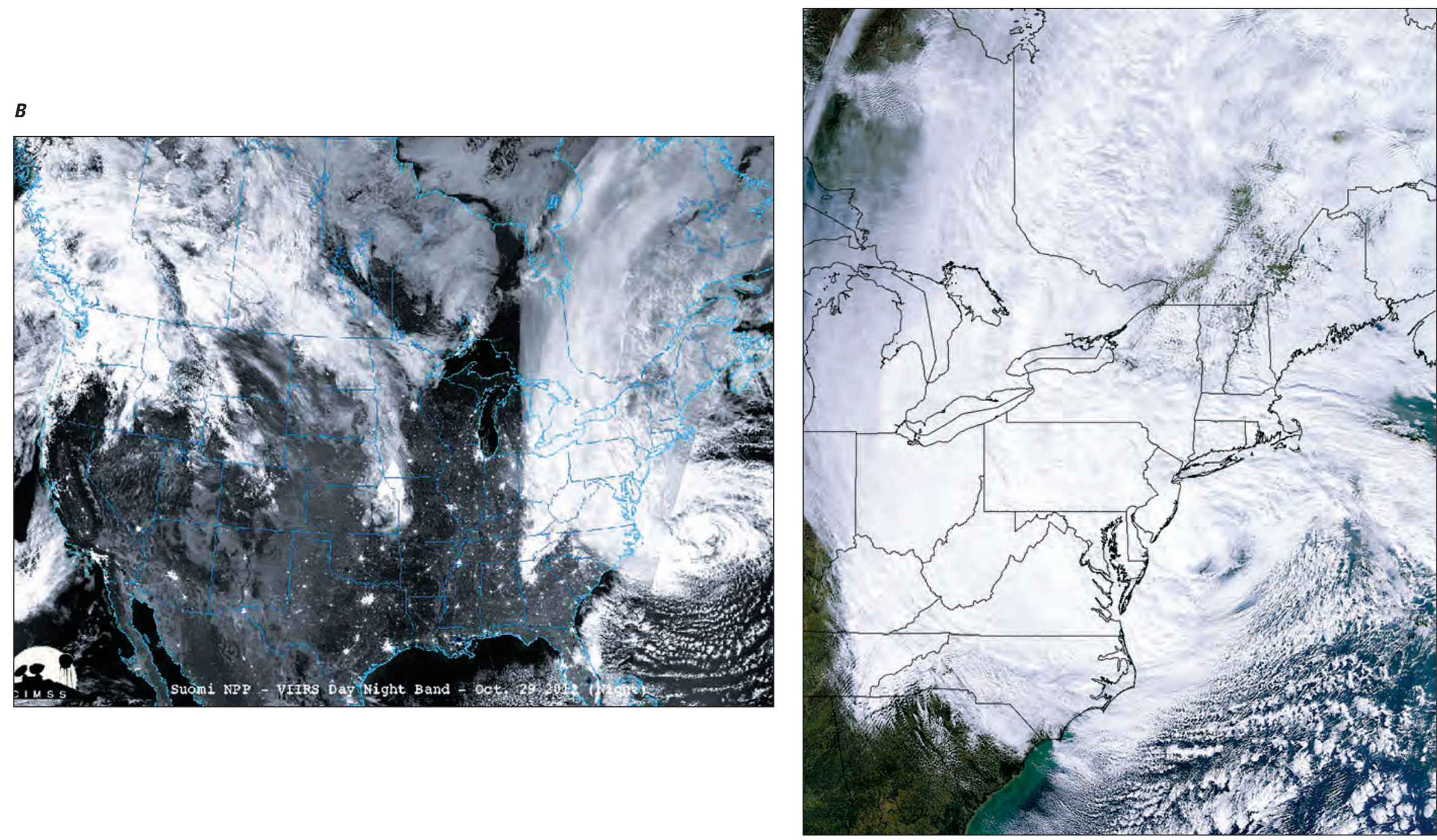

Figure 1. A, Hurricane Sandy track and intensity, as well as locations of moored National Oceanic and Atmospheric Administration (NOAA) National Data Buoy Center (NDBC) buoys recording wave height and period (adapted from Sopkin and others, 2014). B, Nighttime image of Hurricane Sandy captured 16-18 hours before landfall by the Visible Infrared Imaging Radiometer Suite (VIIRS) on the National Aeronautics and Space Administration (NASA)/NOAA Suomi National Polar-orbiting Partnership satellite, a composite of several satellite passes (image provided by University of Wisconsin-Madison). C, NASA Aqua satellite image of Hurricane Sandy, 0ctober 29, 2012, 2:20 p.m. EDT (NASA, 2013; both images accessed at https://www.nasa.gov/mission_pages/hurricanes/archives/2012/h2012_Sandy.htm|\#11)._Continued 


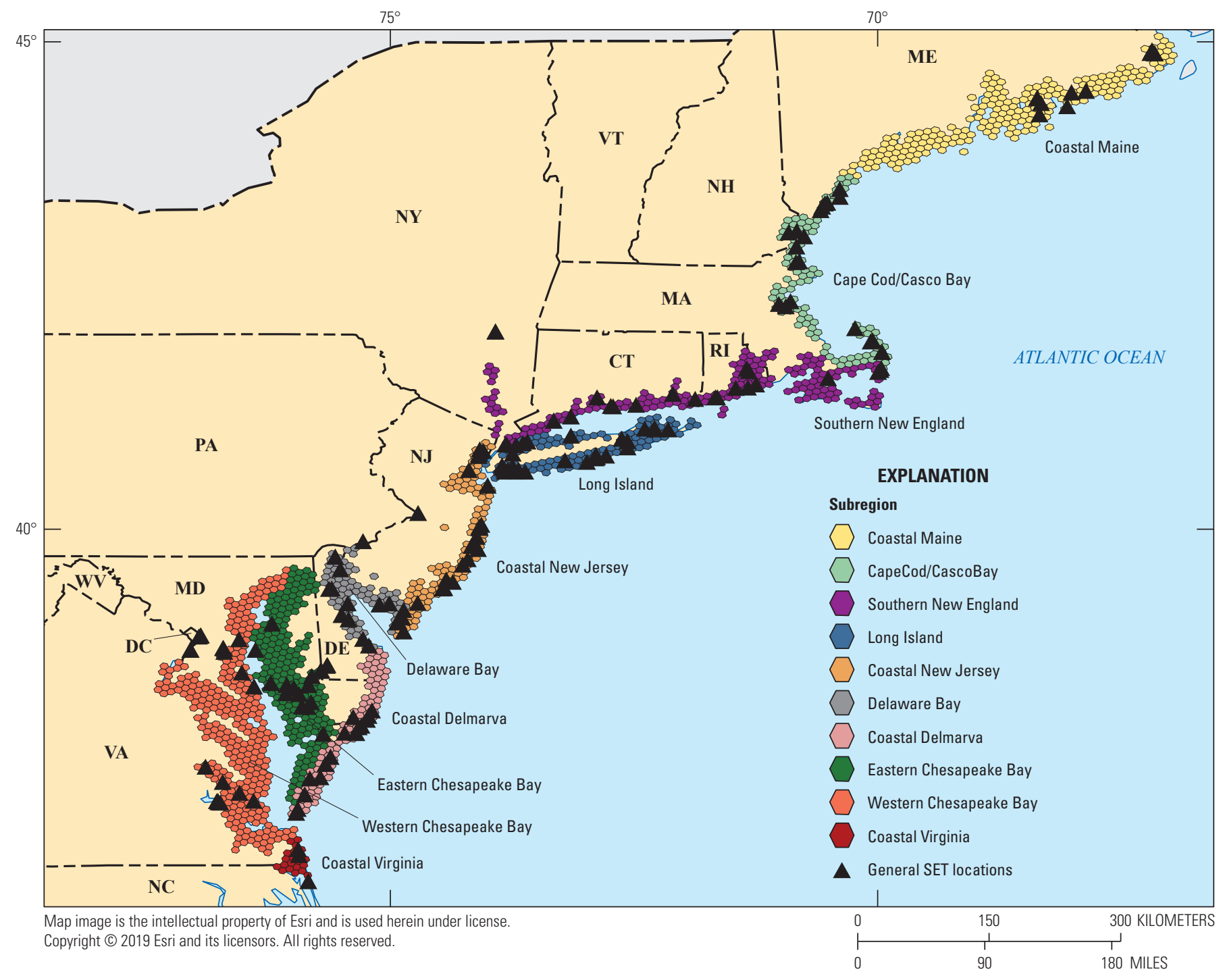

Figure 2. Study region between Maine and Virginia (inclusive) indicating 10 subregions and the general locations of surface elevation table-marker horizon (SET-MH) station clusters (965 stations in total).

sites in North Carolina and USGS sites in Canada that are outside the prescribed study area and were subsequently removed from the inventory.

\section{Data Formatting and Analyses}

All metadata received were subjected to a quality control/ quality assurance process. These practices included contacting SET practitioners with follow-up questions and identification of potential errors in datasets (for example, incorrect coordinates, outliers in data, labelling errors, to name only a few). Once formatted, SET-MH stations were identified as appropriate for inclusion in the inventory (objective 1). The Preferred Reporting Items for Systematic Reviews and Meta-Analyses (PRISMA) approach (Moher and others, 2009) was used for identifying, screening, and determining eligibility of sites based on the following criteria:
1. Within study area for monitoring network (Virginia to Maine),

2. The original pipe SET or deep rod SET method was used (shallow SET benchmark method was excluded),

3. Estuarine emergent marsh habitats (freshwater tidal marshes, forested, and highly managed sites excluded), and

4. SET-MH station was functional (not damaged).

An explanation of the criteria and the exclusions are provided below. 


\section{Location and Distribution of Stations}

For all SET-MH stations included in the inventory, we verified geographic location and assessed geomorphic setting with high resolution aerial photography following the broad setting and subsetting classification scheme in Cahoon and others (2009). See table 1 for more details. Furthermore, the study area between Maine and Virginia (inclusive) was partitioned into ten subregions (fig. 2): (1) coastal Maine, (2) Cape Cod and Casco Bay, (3) southern New England, (4) Long Island, (5) coastal New Jersey, (6) Delaware Bay, (7) Coastal Delmarva, (8) eastern Chesapeake Bay, (9) western Chesapeake Bay, and (10) coastal Virginia. These subregions were based on major tidal systems as defined in Conway and Droege (2006). The boundaries of the subregions are described in table 2. A hexagon sampling grid (40 square kilometers $\left[\mathrm{km}^{2}\right]$ ) was used to partition the subregions into smaller

Table 1. Geomorphic settings of coastal wetlands in the mid-Atlantic coast of the United States (Cahoon and others, 2009).

\begin{tabular}{ll}
\hline \multicolumn{1}{c|}{ Geomorphic setting } & \multicolumn{1}{c}{ Description } \\
\hline Open coast & Areas sheltered from waves and \\
& currents as a result of coastal \\
& topography or bathymetry \\
Back-barrier lagoon marsh & Occupies fill within transgressive \\
& back-barrier lagoons \\
& Back-barrier: lagoonal side of a \\
& marine barrier \\
& Lagoonal fill: occupies fill in a back- \\
& barrier lagoon \\
& Transgressive marsh: transgressive \\
& marshes bordering uplands in a \\
& back-barrier lagoon \\
Shallow coastal embayment with \\
some river discharge, frequently a \\
drowned river valley \\
Saline fringe marsh: transgressive \\
marshes bordering uplands at the \\
lower end of estuaries \\
Stream channel wetlands: occupy \\
estuarine-alluvial channels rather \\
than open coast
\end{tabular}

units, to aid assessment, and to graphically represent marsh and SET-MH information at a scale appropriate for the large study area (Weist and others, 2016). This tessellated hexagon sampling design (Stevens and Olsen, 2004) can be used for comparison across subregions with uniform-sized sample units (fig. 2).

A preliminary evaluation of the database revealed a majority of stations occurred in estuarine emergent marsh settings. Thus, hexagons were limited to locations that contained the estuarine emergent marsh setting identified using National Wetlands Inventory (NWI) estuarine emergent marsh data (NWI code E2EM) acquired in 2010 from the U.S. Fish and Wildlife Service (http://www.fws.gov/Wetlands/NWI/). NWI emergent marsh polygons were assigned unique marsh patch identification, and adjacent polygons within a 50-m buffer were considered the same patch (Wiest and others, 2016) and given a single identification. We assigned the estuarine emergent marsh identified by NWI to one of two possible geomorphic settings: estuarine marsh or back-barrier lagoonal marsh (Cahoon and others, 2009). For each marsh patch, marsh area (in hectares [ha]) was calculated (ArcMap 10.1) and the primary broad geomorphic setting assigned using high resolution aerial photography. When a patch included two or more broad geomorphic settings, the dominant broad setting was used.

Table 2. Subregion names and boundaries (see fig. 2 for map).

\begin{tabular}{|c|c|}
\hline Subregion & Boundaries \\
\hline Coastal Maine & $\begin{array}{l}\text { Lubec, Maine, to north of Casco Bay, } \\
\text { Maine }\end{array}$ \\
\hline Cape Cod, Casco Bay & $\begin{array}{l}\text { Casco Bay, Maine, to Cape Cod, Mas- } \\
\text { sachusetts-including north side of } \\
\text { U.S. Route } 6 \text { Mid-Cape Highway }\end{array}$ \\
\hline Southern New England & $\begin{array}{l}\text { South of Cape Cod, Massachusetts- } \\
\text { including south side of U.S. Route } 6 \\
\text { Mid-Cape Highway, Nantucket } \\
\text { Island, Martha's Vineyard Island to } \\
\text { Hudson River, New York, including } \\
\text { Bronx, New York }\end{array}$ \\
\hline Long Island & $\begin{array}{l}\text { Long Island, New York, including } \\
\text { Queens, New York }\end{array}$ \\
\hline Coastal New Jersey & $\begin{array}{l}\text { New Jersey Meadowlands to Cape } \\
\text { May, New Jersey (oceanside), } \\
\text { including Staten Island, New York }\end{array}$ \\
\hline Delaware Bay & $\begin{array}{l}\text { Cape May, New Jersey (bayside), to } \\
\text { Lewes, Delaware (bayside) }\end{array}$ \\
\hline Coastal Delmarva & $\begin{array}{l}\text { Delmarva Peninsula oceanside from } \\
\text { Lewes, Delaware, to Fisherman's } \\
\text { Island National Wildlife Refuge, } \\
\text { Virginia }\end{array}$ \\
\hline Eastern Chesapeake Bay & $\begin{array}{l}\text { Chesapeake Bay coastline east of } \\
\text { Susquehanna River mouth }\end{array}$ \\
\hline Western Chesapeake Bay & $\begin{array}{l}\text { Chesapeake Bay coastline west of } \\
\text { Susquehanna River mouth }\end{array}$ \\
\hline Coastal Virginia & $\begin{array}{l}\text { Virginia Beach, Virginia, oceanside to } \\
\text { North Carolina border }\end{array}$ \\
\hline
\end{tabular}




\section{Metadata Summary}

Metadata were received for 1,230 SET-MH stations. These metadata were collected from colleagues across 10 states (from Virginia to Maine) from NOAA National Estuarine Research Reserves; U.S. Fish and Wildlife Service national wildlife refuges; National Park Service parks, seashores, and recreation areas; State Wildlife Management Areas; National Science Foundation Long Term Ecological Research Network sites; the Long Island Sound Study; Partnership for the Delaware Estuary/Barnegat Bay Partnership-Mid-Atlantic Coastal Wetlands Assessment; the New York City Department of Parks and Recreation; The Nature Conservancy; Save the Bay-Narragansett Bay; and private and academic organizations. This SET-MH inventory (appendix 2) resides at the University of Minnesota Duluth. Of the 1,230 SET-MH records, 85 were duplicates, and 180 did not meet the criteria described above and were removed from the inventory (fig. 3). Shallow SET stations were excluded because they were not commonly used in the region and not well represented in the dataset, limiting their value for testing regional hypotheses. But more importantly, they measure elevation change relative only to the depth of the root zone. In contrast, both the pipe SET and the Rod SET were used commonly throughout the region. They measure elevation change to a depth of several tens of meters, thereby measuring both root zone and deeper compaction processes in the substrate. Excluding shallow SET stations reduced confounding effects related to their methodological difference in elevation measurements and their limited spatial coverage. Freshwater tidal marsh settings were excluded because they contained only 30 stations within four geographical locations and all the locations were skewed geographically to the left of Hurricane Sandy landfall. Forested wetland settings were less represented with SET-MH stations than tidal freshwater marsh. Thus, data from these two habitats were not well suited for testing regional hypotheses of storm impacts. SET-MH records were excluded if they were established for experiments: fertilization, exclusion fences, burn, restoration, saltwater addition, elevated carbon dioxide, marsh plugging, and vegetation removal treatments. The inventory of SET-MH stations used in this study presently includes 965 individual stations (fig. 3) in 96 unique geographical locations, based on general area descriptions provided by SET practitioners.

\section{Hurricane Sandy Effects on Coastal Marsh Elevation Change}

\section{Introduction}

The next step in the project was to evaluate the impact of Hurricane Sandy on the elevation trajectories of coastal marshes located across the northeast United States within the area of storm influence (for example, wind field and storm surge). This analysis requires an understanding of both the physical characteristics of the storm and the nature of coastal landforms in the northeast United States it impacted. Some fundamental physical characteristics of tropical cyclones in the northern hemisphere include elevated wind speeds that push and pile up seawater as the storm advances over the ocean and counterclockwise winds. The latter characteristic means that a storm's physical impacts are typically greater in the northeast quadrant (in other words, the upper right quadrant relative to storm direction) caused by winds blowing onshore when the storm makes landfall. In contrast, winds in the northwest quadrant are blowing offshore at the time of landfall. Yet, every storm is unique in terms of its wind speed, size (storm diameter), rate of forward motion, amount of rainfall, timing of landfall relative to tide height, angle of approach to the shore, and the local nearshore bathymetry and coastal geomorphology at the point of landfall (Resio and Westerink, 2008). This unique set of physical characteristics determines the intensity and duration of a storm's impact on coastal landforms it encounters.

\section{Physical Characteristics of the Storm}

On October 28, 2012, Hurricane Sandy travelled north on a track parallel to the Atlantic coast of the United States, with the strongest winds on its western side (fig. $1 B$; and see fig. 7 in Blake and others, 2013). When the hurricane reached the mid-Atlantic region (National Aeronautics and Space Administration, 2013; fig. $1 A, B$ ) it combined with a cold front moving from the northwest. The storm turned to the northwest and made landfall on October 29, 2012, as a post-tropical cyclone near Brigantine, New Jersey, (fig. 1A) with maximum sustained winds of $130 \mathrm{~km} / \mathrm{h}$ (70 kn; Blake and others, 2013). As a result of this turn, coastal habitats located to the right of the landfall point continued to be inundated by winds of the northeast quadrant pushing water ashore. In contrast, coastal habitats located to the left of the landfall point experienced strong winds out of the northwest shifting to out of the southwest during storm passage (fig. $1 B, C$ ), thereby limiting the extent and depth of storm surge in this region (Dennison and others, 2012).

The major impacts of Hurricane Sandy on coastal environments were related to the effects of storm surge and 

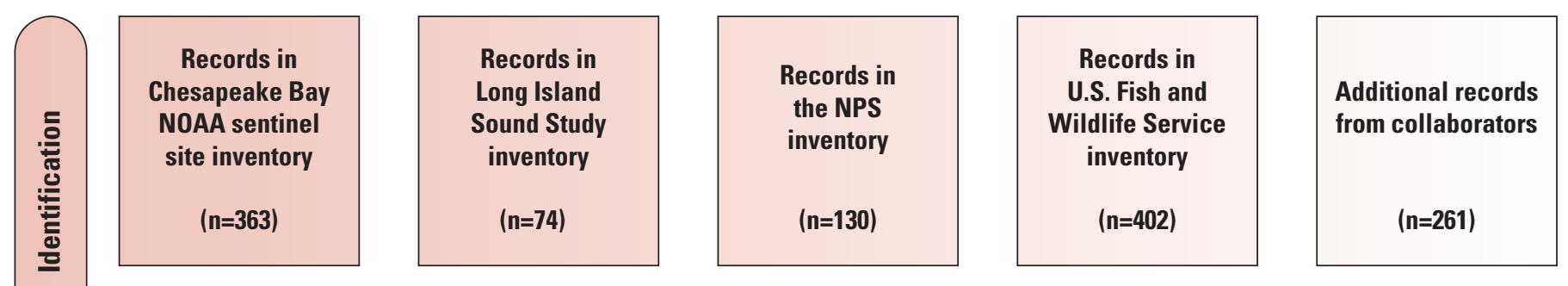

Total $(n=1,230)$
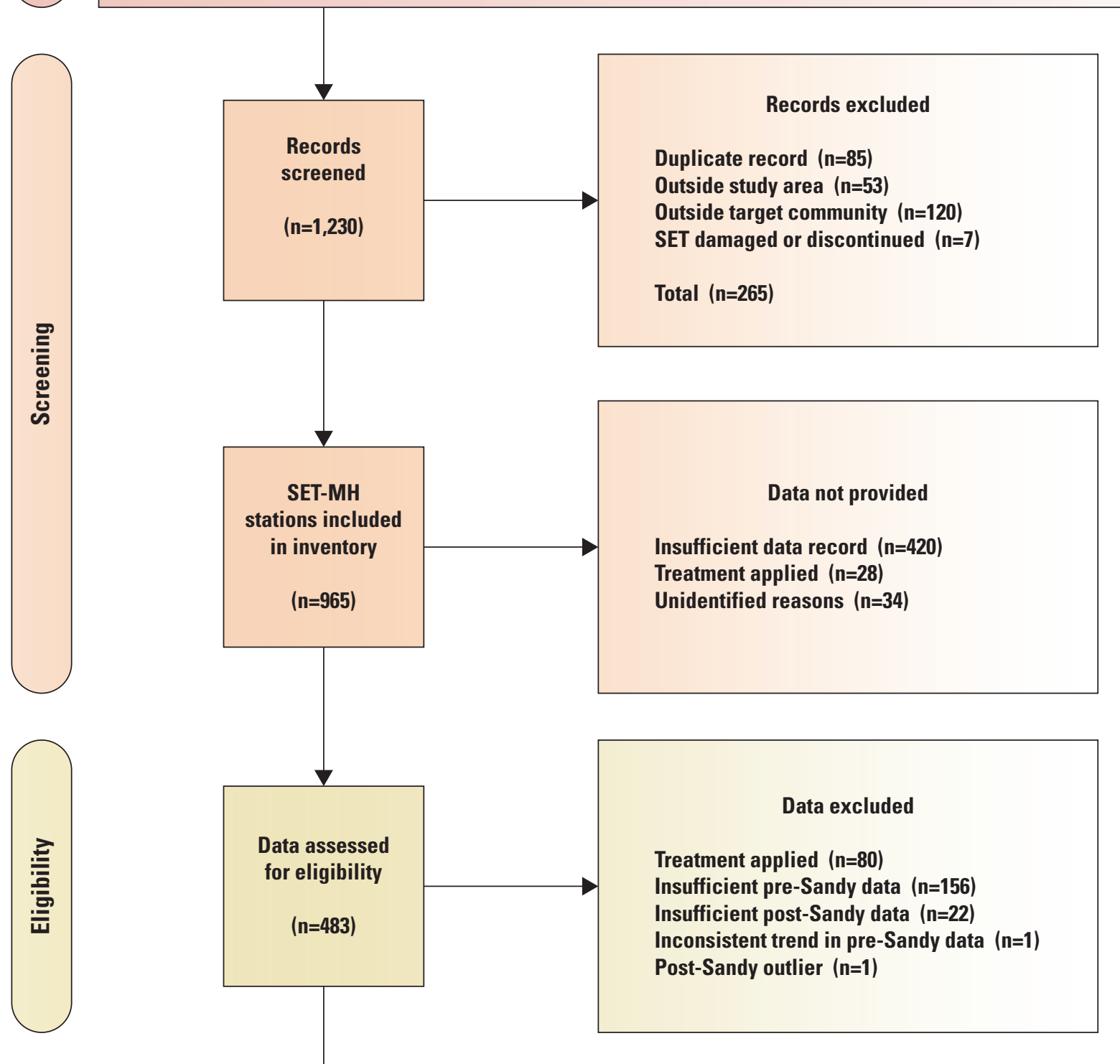

Figure 3. Preferred Reporting Items for Systemic Reviews and MetaAnalyses flow diagram detailing the omission of surface elevation tablemarker horizon (SET-MH) records from the inventory and the Hurricane Sandy effects analysis. Records are removed from the tally as you move down the flow diagram and the list within each box.

(NOAA, National Oceanic and Atmospheric Administration; NPS, National Park Service; $\mathrm{n}=$ number of SET-MH stations) 
associated coastal flooding (Blake and others, 2013; ValleLevinson and others, 2013). Several factors contributed to the creation of record high storm surge and coastal inundations in the New Jersey, New York, and Connecticut region north of landfall. The storm was very large with the extent (diameter) of tropical-storm-force winds growing to about $1,611 \mathrm{~km}$ prior to landfall (Blake and others, 2013). In addition, Hurricane Sandy made landfall at high tide and at an angle closer to perpendicular to the New Jersey shore than any hurricane in the historical record (Hall and Sobel, 2013). The return period for a storm of Hurricane Sandy's intensity with this angle of approach is 714 years (Hall and Sobel, 2013). These factors, combined with the configuration of the New Jersey-New York-Connecticut shoreline and New York Bight bathymetry, caused the storm surge to rise up to $3.86 \mathrm{~m}$ in the vicinity of New York City (Blake and others, 2013). A record storm tide (the combination of the storm surge and astronomical tide) of $4.28 \mathrm{~m}$ was recorded at the Battery in New York City (Blake and others, 2013). Historical increases in sea level and mean flood heights contributed to the record high storm surge and storm tide heights at New York City generated by Hurricane Sandy (Kemp and Horton, 2013; Talke and others, 2014; Kemp and others, 2017; Reed and others, 2015). Another contributing factor was the three-fold decrease in the return period for a storm of Hurricane Sandy's flood height during the past two centuries (Lin and others, 2016). Consequently, the inundations above ground level (in other words, upland surfaces) for parts of this region of the coast were as much as $3 \mathrm{~m}$ (Blake and others, 2013) during Hurricane Sandy. In contrast, the peak in storm surge height to the left of landfall in the coastal bays of the Delmarva Peninsula behind Fenwick and Assateague barrier islands was only $\sim 1.2 \mathrm{~m}$ (Dennison and others, 2012).

\section{Hypotheses}

We hypothesized that differences in physical drivers of storm surge extent and duration on either side of a storm's point of landfall could differentially influence the coastal marsh processes related to sediment deposition, sediment erosion, soil compaction (from storm surge water overburden), and ultimately marsh elevation change (Cahoon, 2006). Based on our understanding of the physical characteristics of Hurricane Sandy, we used existing knowledge to develop a hypothetical structural equation model (SEM) describing the processes driving post-storm deviation from expected surface elevation change in millimeters (fig. 4). Structural equation modeling is a methodology to address questions about complex systems; it is best understood as a framework for quantitative analysis that uses statistical techniques, rather than a statistical method itself, and permits the evaluation of networks of direct and indirect effects (Grace and others, 2012). The SEM approach used in this study examines both direct and indirect influences on deviation from expected change. Variables representing storm exposure and intensity (for example, distance from landfall and position relative to storm landfall [left or right]), and geomorphic setting are predicted to directly influence both presence of storm surge and deviation from expected change. Additional variables that may account for unexplained variance (for example, the rate and variation in prestorm surface elevation change) are not predicted to influence storm surge exposure and are therefore included only as possible direct effects on deviation from expected change.

\section{Methods}

\section{Eligible SET-MH Stations}

Although the SET-MH inventory contains 965 stations (fig. 2), after determining eligibility for inclusion in our analyses (see description below; eligible stations include $\mathrm{SET}=223$ and $\mathrm{MH}=107$ ), only the SET elevation data were included in our analysis of Hurricane Sandy effects. Accretion data had an inadequate level of replication for inclusion because a large number of stations with eligible SET data were missing marker-horizon data (55) or had insufficient prestorm (160) or poststorm data (93). Without including the accretion data, it was not possible to calculate shallow subsidence at the stations, so this variable is not addressed in this report.

Of the 965 stations eligible for inclusion in the SET-MH inventory, data were not provided for 482 stations owing to insufficient data record (420), experimental treatment applied (28), or unidentified reasons (34). Eligibility for analysis of the remaining 483 stations was determined using a stepwise exclusion process. Station data (fig. 3) were excluded by criteria in the following order: experimental treatment applied (80), insufficient prestorm data (156), insufficient poststorm data (22), inconsistent trend in prestorm data (1), and a poststorm residual distance outlier (1). In some cases, data were not provided if the provider knew a site was ineligible for assessment; however, a reason was not always given. In order to minimize seasonal variation, we chose one eligible season per SET (either winter/spring or summer/autumn) and only included data from within that season in an analysis. A season was eligible if it had at least one measurement within 1 year poststorm and had $\geq 3$ years of prestorm data (table 3 ). Poststorm data were ineligible if there was no poststorm measurement in an eligible season ( $\geq 3$ years in prestorm record) within 1 year following Hurricane Sandy (October 2012-October 2013). Measurement season was consistent within a specific station but varied among stations. 


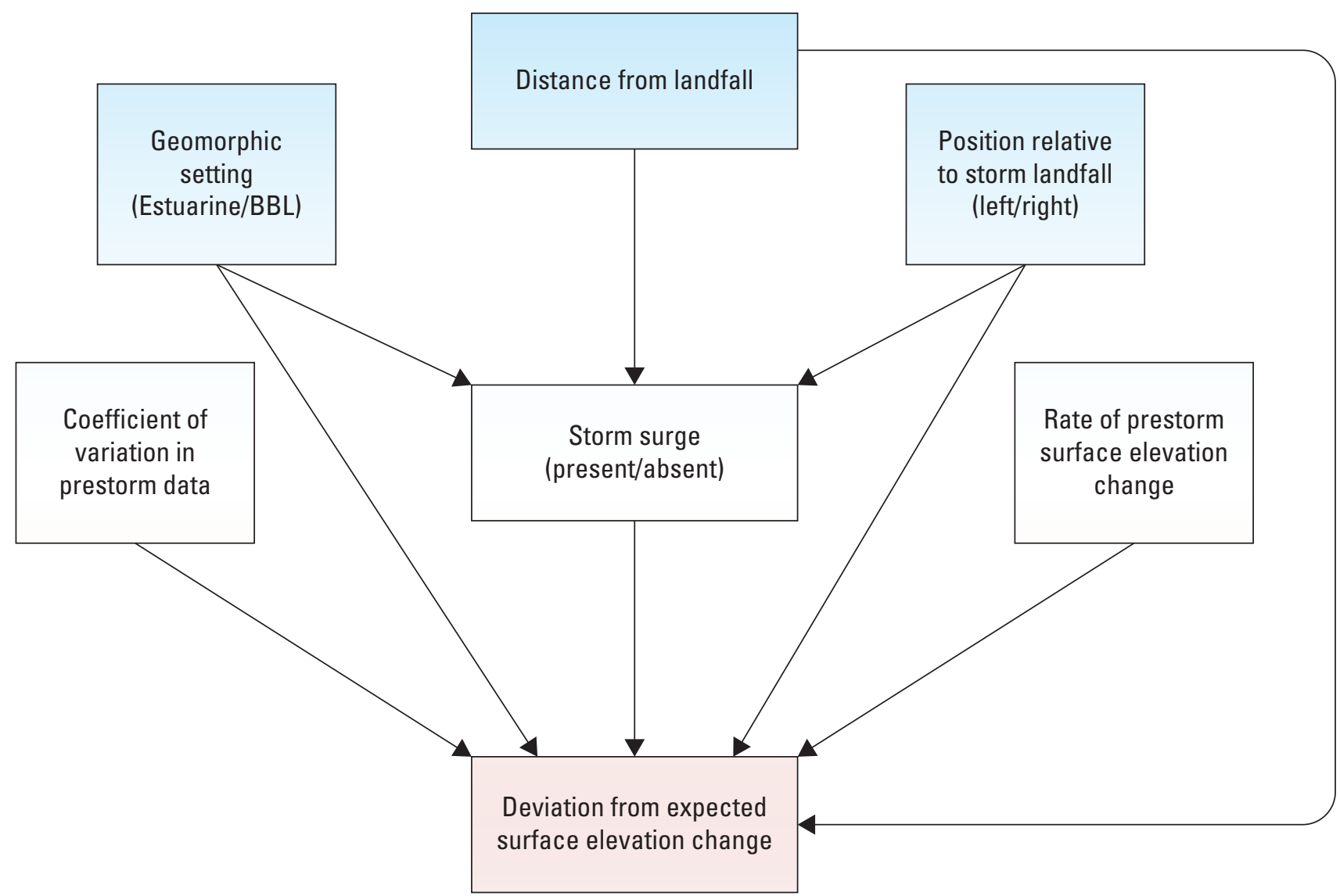

Figure 4. Initial structural equation model illustrating the hypothetical pathways between predictor variables and response variables. Predictors include distance to landfall, geomorphic setting (estuarine or back-barrier lagoon [BBL]), position relative to landfall (left or right), coefficient of variation in prestorm data, and rate of prestorm elevation change. Exposure to storm surge is both a predictor and a response variable.

Table 3. Five hypothetical examples of surface elevation table (SET) survey times and exclusion of data from analyses based on season of prestorm and poststorm measurements. All data were included when the prestorm and poststorm measurements were recorded in the same season and there was a minimum of 3 years prestorm data (a). A subset of the data was included when prestorm measurements were recorded in multiple seasons and at least one season had $\geq 3$ years of prestorm data and a poststorm record $(b-c)$. A SET was excluded from analysis when prestorm and poststorm measurements were recorded in different seasons (d) or when prestorm and poststorm measurements were recorded in the same season, yet the number of years in the prestorm record was $<3$ (e).

$[\geq$, greater than or equal to; $<$, less than; - , no data $]$

\begin{tabular}{|c|c|c|c|c|c|}
\hline \multirow{2}{*}{$\begin{array}{l}\text { Data used } \\
\text { in analyses }\end{array}$} & \multicolumn{2}{|c|}{$\begin{array}{l}\text { Number of years with } \\
\text { prestorm measurements }\end{array}$} & \multicolumn{2}{|c|}{$\begin{array}{c}\text { Poststorm } \\
\text { measurement season }(x)\end{array}$} & \multirow{2}{*}{$\begin{array}{l}\text { Season used } \\
\text { in analyses }\end{array}$} \\
\hline & Winter/Spring & Summer/Autumn & Winter/Spring & Summer/Autumn & \\
\hline (a) All data & 0 & $\geq 3$ & - & $\mathrm{x}$ & Summer/Autumn \\
\hline (b) Subset & $\geq 3$ & $\geq 1$ & $\mathrm{x}$ & - & Winter/Spring \\
\hline (d) Excluded & $\geq 3$ & 0 & - & $\mathrm{x}$ & Neither \\
\hline (e) Excluded & 0 & $<3$ & - & $\mathrm{x}$ & Neither \\
\hline
\end{tabular}




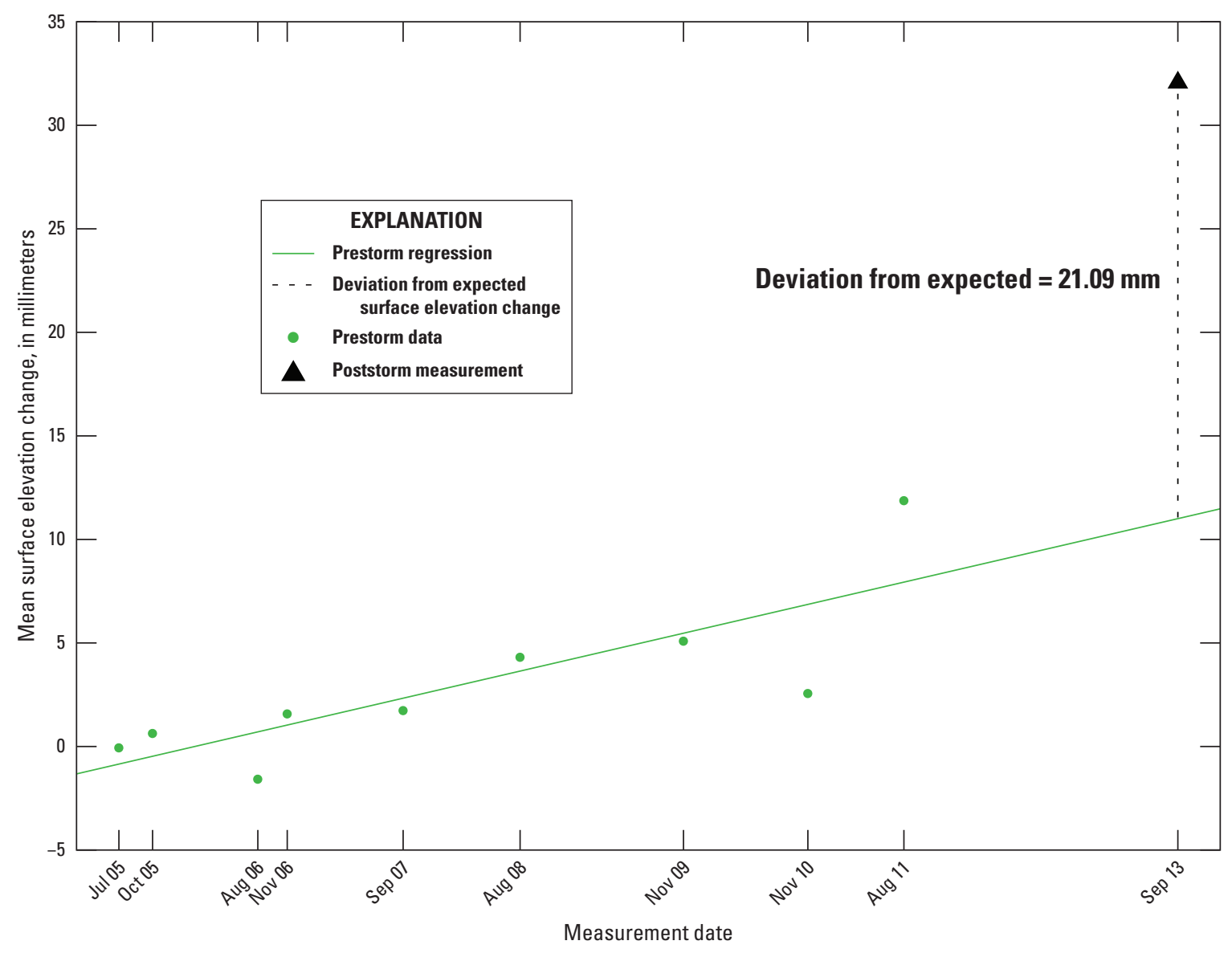

Figure 5. Mean surface elevation change from July 2005 to September 2013 at the U.S. Geological Survey Blackwater 7D.1 surface elevation table (Cambridge, Md). Regression was calculated from prestorm data. The poststorm measurement had a deviation from expected surface elevation change of 21.09 millimeters $(\mathrm{mm})$.

\section{Elevation Response Variable}

Deviation from the expected surface elevation change trend poststorm was used as the measure of Hurricane Sandy effect on marsh surface elevation. We measured the deviation from expected change at each station as the residual distance of the poststorm mean from the regression line predicted by the prestorm means (fig. 5) using a distance to line $\mathrm{R}$ function developed by Bourke (2015). Prestorm trends were calculated from measurements made within the same season as the poststorm measurement (fig. 5, table 3 ) and poststorm measurements were made within the year following storm passage (between November 6, 2012, and October 30, 2013, fig. 6). Total surface elevation change is the mean change in pin height since baseline for each SET, in order to accommodate different numbers of pins among some SETs.

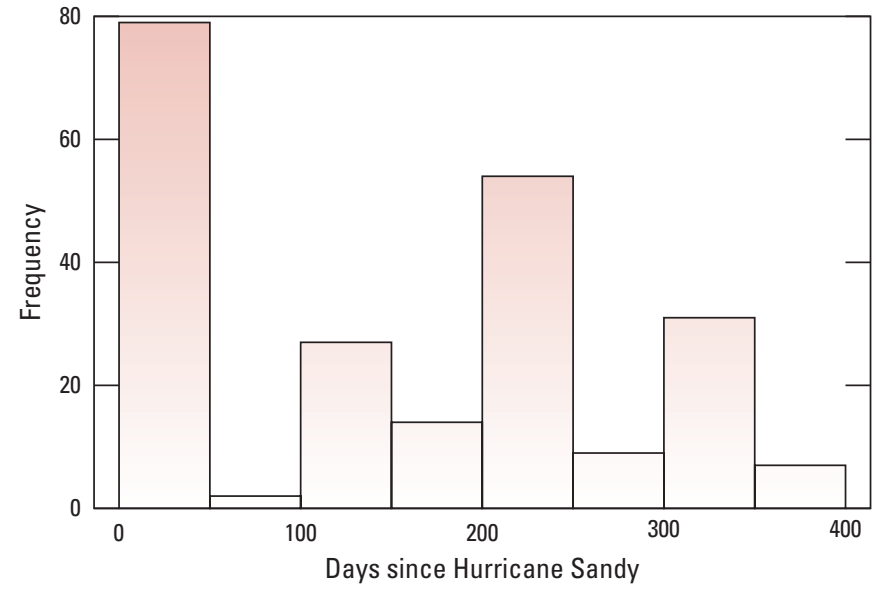

Figure 6. Frequency distribution of number of days between Hurricane Sandy (October 30, 2012) and the poststorm surface elevation table measurement for each eligible station. 


\section{Predictor Variables}

The predictor variables fall into two categories: (1) variables representing storm exposure and intensity, and (2) variables that may account for additional variance in the deviation from expected surface elevation change poststorm.

\section{Variables Representing Storm Exposure and Intensity}

\section{Distance to Storm Landfall}

We calculated the distance from SET station to storm landfall $\left(39.4^{\circ} \mathrm{N}, 74.4^{\circ} \mathrm{W}\right.$; Blake and others, 2013) using the sp package in $\mathrm{R}$ version 3.3.1 (Pebesma and Bivand, 2005; Bivand and others, 2013; R Core Team, 2016). Distance was calculated in kilometers and was scaled prior to analysis to increase similarity with the magnitude of other predictors $($ dist. $=$ distance to landfall/1,000).

\section{Exposure to Storm Surge (Within or Outside Surge Zone)}

Storm surge area was obtained from the Hurricane Sandy Impact Analysis-Federal Emergency Management Agency (FEMA) Modeling Task Force (MOTF; 2015a). As highresolution data did not cover the entire study region, we used the Medium and Low Resolution Storm Surge Extent (Interim 30-meter Storm Surge Extent 110112) in ArcGIS 10.1 to assign a storm surge category (present/absent). Stations that were assigned to the storm-surge-absent category were visually examined and were reassigned if they met at least one of the following criteria. If the station was

1. on the open water side of the storm surge boundary $(n=4$ SET $)$;

2. within $1 \mathrm{~m}$ of the storm surge boundary ( $\mathrm{n}=2 \mathrm{SET})$;
3. within a small pocket of absent space within the storm surge boundary, artifacts derived from a minimum mapping unit of $30 \mathrm{~m}(\mathrm{n}=6$ SET);

4. on a small island where the adjacent mainland was within the storm surge boundary $(\mathrm{n}=12 \mathrm{SET})$; or

5. within the high-resolution storm surge boundary $(\mathrm{n}=12 \mathrm{SET})$.

Stations exposed to (present) and those not exposed to (absent) the storm surge were assigned a 1 or 0 , respectively, during analysis.

\section{Geomorphic Setting}

Stations were assigned to one of two potential geomorphic settings: (1) estuarine marsh and (2) back-barrier lagoonal marsh (Cahoon and others, 2009). Stations within estuaries that flowed into back-barrier lagoons were included in the latter category, as the barrier island was likely to influence storm surge timing and severity. Stations within estuaries and those within back-barrier lagoons were assigned a 1 or 0 , respectively, during analysis.

\section{Position Relative to Storm Landfall}

Position relative to landfall was assigned as those to the left (south) or those to the right (north) of storm landfall $\left(39.4^{\circ} \mathrm{N}, 74.4^{\circ} \mathrm{W}\right.$; Blake and others, 2013). Stations to the left or right were assigned a 1 or 0 , respectively, during analysis. This variable represents a complex array of processes. Different physical characteristics between the two positions include, but are not restricted to, wind intensity and direction, movement of water and surge retention time, geomorphic setting, and differences in underlying parent material which may have implications for sediment transport and trapping (table 4; Stevenson and others, 1988).

Table 4. Number of surface elevation table (SET) stations used in analyses and distance to storm landfall (minimum, maximum, and range) for each unique geomorphic and geographic location category. Categories based on geomorphic setting (back-barrier lagoon, estuarine) and position relative to landfall (left or right).

[na, not applicable]

\begin{tabular}{|c|c|c|c|c|c|c|}
\hline \multirow{2}{*}{ Data } & \multirow{2}{*}{ Descriptor } & \multicolumn{2}{|c|}{ Back-barrier lagoon } & \multicolumn{2}{|c|}{ Estuarine } & \multirow{2}{*}{ Tota } \\
\hline & & Left of landfall & Right of landfall & Left of landfall & Right of landfall & \\
\hline SET & Number of SET stations & 26 & 90 & 78 & 29 & 223 \\
\hline SET & Minimum distance (kilometers) & 154.47 & 8.04 & 89.97 & 152.34 & na \\
\hline SET & Maximum distance (kilometers) & 249.03 & 557.14 & 298.90 & 303.91 & na \\
\hline
\end{tabular}


Additional Variables to Account for Unexplained Variance

\section{Coefficient of Variation}

Coefficient of variation (CV) of the residual distance from the prestorm elevation trend line was calculated using the formula $\mathrm{CV}=($ Standard deviation*100)/mean residual distance of prestorm measurements per SET. This metric indicates the natural long-term variation at the site.

\section{Rate of Change}

Rate of change in the prestorm record (millimeters per year $[\mathrm{mm} /$ year $]$ ) was calculated for elevation data. To calculate rate of change, we used mean difference in pin height from the first pin measurement (28-36 pin measurements) to fit a regression line through multi-year surveys ( $\geq 3$ years) within the same season using R version 3.3.1 (R Core Team, 2016). This metric was used to calculate the deviation from expected poststorm measurement for each SET station and as an indication of long-term trends in marsh elevation change.

\section{Correlation Between Predictor Variables}

We used generalized variance inflation factor analysis (VIF) to assess the co-linearity between predictor variables using the car package in R version 3.3.1 (Zuur and others, 2009; Fox and Weisberg, 2011; R Core Team, 2016). Variables with a VIF $>3$ are generally considered to have high co-linearity. Additionally, we generated bivariate plots to visualize correlations between predictor variables.

\section{Structural Equation Model}

The deviation from expected elevation change model and storm surge submodel in figure 4 (hypothetical model) were analyzed separately. We used a piecewise approach to model estimation and evaluation rather than relying on an assessment of covariance relations (Grace and others, 2012). This approach allowed us to choose from a broader array of tools for evaluating each endogenous (response) node. Corrected Akaike's Information Criterion (Burnham and Anderson, 2002) was used for comparing candidate models chosen for interpretation.

\section{Model Building}

We hypothesized there would be a nonlinear positive response between distance to storm landfall and both response variables (deviation from expected and presence of storm surge) where the effect would plateau beyond the region of influence. We therefore allowed for base models to accommodate a quadratic distance curve.

To determine the best model of deviation from the expected elevation change, a logical subset of all possible models was assessed. All candidate models included distance to storm landfall, and predictor variables were added to this base model in a stepwise fashion. Model complexity increased with each additional predictor until all main effects were included in a full model. Variable addition was based on the degree of correlation between the residuals from the previous model and the remaining predictor variables. Interactions between distance to storm landfall and all other variables, and between geomorphic setting and all other variables were then considered and added to the full model. For simplicity, models included only one interaction, and the interaction terms were always retained as a main effect. The main effects were examined in each interaction model, and the variable with the greatest $P$ value was removed from the subsequent model. This process was repeated on the simplified model and continued until all main effects were either present in an interaction or had a $P$ value of $<0.05$. A total of 46 models were included in the deviation from expected surface elevation list (table 5).

All storm surge submodels included distance to storm landfall. Position relative to landfall and geomorphic setting were included as main effects and in interaction with the distance variable. No models included both categorical predictor variables. A total of five models were included in the storm surge submodel list (table 6).

\section{Model Assessment}

Model assessment ensured a consideration of all possible linkages, with evaluations based on Akaike's Information Criterion with a correction for finite sample sizes (AICc; Burnham and Anderson, 2002). Candidate models for each response variable were ranked using their AICc value. The difference in $\mathrm{AICc}$ from the lowest $\mathrm{AICc}$ value $\left(\mathrm{AICc}_{\min }\right)$ was calculated for each candidate model $\left(\triangle \mathrm{AICc}=\mathrm{AICc}-\mathrm{AICc}_{\min }\right)$ and models with $\triangle \mathrm{AICc}<2$ were considered equivalent (Burnham and Anderson, 2002). The simplest model with the lowest AICc within this top model list was considered the best model, and its parameter estimates were examined and interpreted. Models were compared using the AICcmodavg package in R version 3.3.1 (Mazerolle, 2016; R Core Team, 2016).

\section{Spatial Autocorrelation}

Spatial autocorrelation occurs when the residuals of data points that are spatially close together are not independent (Bivand and others, 2013). We used Moran's I to statistically test for residual spatial autocorrelation in the deviation from expected response variable using the spdep package in R version 3.3.1 (Bivand and Piras, 2015; R Core Team, 2016). Spatial autocorrelation was assessed on links between seven neighboring pairs $(\mathrm{k}=7)$. Weights 
Table 5. Models used to determine deviation from expected surface elevation change, measured as the residual distance of poststorm elevation change. Number of models $=46$. Predictors include distance to storm landfall (kilometers/1,000; distance) as a quadratic curve, rate of prestorm elevation change (millimeters/year), position relative to landfall, exposure to storm surge, coefficient of variation (millimeters), and geomorphic setting. Models with the same number include the same interaction term, indicated by an asterisk.

[-, no data $]$

\begin{tabular}{|c|c|c|c|c|c|c|}
\hline Model & $\begin{array}{c}\text { Distance } \\
+ \text { distance }^{2}\end{array}$ & $\begin{array}{c}\text { Rate of } \\
\text { prestorm change }\end{array}$ & $\begin{array}{l}\text { Position relative } \\
\text { to landfall }\end{array}$ & $\begin{array}{l}\text { Storm } \\
\text { surge }\end{array}$ & $\begin{array}{l}\text { Coefficient } \\
\text { of variation }\end{array}$ & $\begin{array}{c}\text { Geomorphic } \\
\text { setting }\end{array}$ \\
\hline $1 \mathrm{~b}$ & $\mathrm{x}$ & - & - & - & - & - \\
\hline 2 & $\mathrm{x}$ & $\mathrm{x}$ & - & - & - & - \\
\hline 3 & $\mathrm{x}$ & $\mathrm{x}$ & $\mathrm{x}$ & - & - & - \\
\hline 4 & $\mathrm{x}$ & $\mathrm{x}$ & $\mathrm{x}$ & $\mathrm{x}$ & - & - \\
\hline 5 & $\mathrm{x}$ & $\mathrm{x}$ & $\mathrm{x}$ & $\mathrm{x}$ & $\mathrm{x}$ & - \\
\hline 6 & $\mathrm{x}$ & $\mathrm{x}$ & $\mathrm{x}$ & $\mathrm{x}$ & $\mathrm{x}$ & $\mathrm{x}$ \\
\hline $7 a$ & $\mathrm{x}$ & $\mathrm{x}^{*}$ & $\mathrm{x}$ & $\mathrm{x}$ & $\mathrm{x}$ & $\mathrm{x}^{*}$ \\
\hline $7 \mathrm{~b}$ & $\mathrm{x}$ & $\mathrm{x}^{*}$ & $\mathrm{x}$ & $\mathrm{x}$ & - & $\mathrm{x}^{*}$ \\
\hline $7 \mathrm{c}$ & $\mathrm{x}$ & $\mathrm{x}^{*}$ & - & - & - & $\mathrm{x}^{*}$ \\
\hline $7 \mathrm{~d}$ & $\mathrm{x}$ & $\mathrm{x}^{*}$ & $\mathrm{x}$ & - & - & $\mathrm{x}^{*}$ \\
\hline $8 \mathrm{a}$ & $\mathrm{x}$ & $\mathrm{x}$ & $\mathrm{x}$ & $\mathrm{x}^{*}$ & $\mathrm{x}$ & $\mathrm{x}^{*}$ \\
\hline $8 \mathrm{~b}$ & $\mathrm{x}$ & $\mathrm{x}$ & $\mathrm{x}$ & $\mathrm{x}^{*}$ & - & $\mathrm{x}^{*}$ \\
\hline $8 \mathrm{c}$ & $\mathrm{x}$ & - & $\mathrm{x}$ & $\mathrm{x}^{*}$ & - & $\mathrm{x}^{*}$ \\
\hline $8 \mathrm{~d}$ & $\mathrm{x}$ & - & - & $\mathrm{x}^{*}$ & - & $\mathrm{x}^{*}$ \\
\hline $9 \mathrm{a}$ & $\mathrm{x}$ & $\mathrm{x}$ & $\mathrm{x}$ & $\mathrm{x}$ & $\mathrm{x}^{*}$ & $\mathrm{x}^{*}$ \\
\hline $9 \mathrm{~b}$ & $\mathrm{x}$ & - & $\mathrm{x}$ & $\mathrm{x}$ & $\mathrm{x}^{*}$ & $\mathrm{x}^{*}$ \\
\hline $9 \mathrm{c}$ & $\mathrm{x}$ & - & $\mathrm{x}$ & - & $\mathrm{x}^{*}$ & $\mathrm{x}^{*}$ \\
\hline $9 \mathrm{~d}$ & $\mathrm{x}$ & - & - & - & $\mathrm{x}^{*}$ & $\mathrm{x}^{*}$ \\
\hline 10a & $x^{*}$ & $\mathrm{x}$ & $\mathrm{x}$ & $\mathrm{x}$ & $\mathrm{x}$ & $\mathrm{x}^{*}$ \\
\hline $10 \mathrm{~b}$ & $\mathrm{x}^{*}$ & $\mathrm{x}$ & $\mathrm{x}$ & $\mathrm{x}$ & - & $\mathrm{x}^{*}$ \\
\hline $10 \mathrm{c}$ & $\mathrm{x}^{*}$ & $\mathrm{x}$ & - & $\mathrm{x}$ & - & $\mathrm{x}^{*}$ \\
\hline $10 \mathrm{~d}$ & $\mathrm{x}^{*}$ & $\mathrm{x}$ & - & - & - & $\mathrm{x}^{*}$ \\
\hline 10e & $\mathrm{x}^{*}$ & - & - & - & - & $\mathrm{x}^{*}$ \\
\hline $11 \mathrm{a}$ & $\mathrm{x}$ & $\mathrm{x}$ & $\mathrm{x}^{*}$ & $\mathrm{x}$ & $\mathrm{x}$ & $\mathrm{x}^{*}$ \\
\hline $11 \mathrm{~b}$ & $x$ & $\mathrm{x}$ & $\mathrm{x}^{*}$ & $\mathrm{x}$ & - & $\mathrm{x}^{*}$ \\
\hline $11 \mathrm{c}$ & $\mathrm{x}$ & $\mathrm{x}$ & $\mathrm{x}^{*}$ & - & - & $\mathrm{x}^{*}$ \\
\hline $11 \mathrm{~d}$ & $\mathrm{x}$ & - & $x^{*}$ & - & - & $\mathrm{x}^{*}$ \\
\hline $12 \mathrm{a}$ & $\mathrm{x}^{*}$ & $\mathrm{x}$ & $\mathrm{x}$ & $\mathrm{x}$ & $x^{*}$ & $\mathrm{x}$ \\
\hline $12 b$ & $\mathrm{x}^{*}$ & $\mathrm{x}$ & $\mathrm{x}$ & $\mathrm{x}$ & $\mathrm{x}^{*}$ & - \\
\hline $12 \mathrm{c}$ & $\mathrm{x}^{*}$ & - & $x$ & $x$ & $x^{*}$ & - \\
\hline $12 \mathrm{~d}$ & $\mathrm{x}^{*}$ & - & $\mathrm{x}$ & - & $\mathrm{x}^{*}$ & - \\
\hline $12 \mathrm{e}$ & $\mathrm{x}^{*}$ & - & - & - & $x^{*}$ & - \\
\hline $13 a$ & $\mathrm{x}^{*}$ & $\mathrm{x}^{*}$ & $\mathrm{x}$ & $\mathrm{x}$ & $\mathrm{x}$ & $x$ \\
\hline $13 b$ & $\mathrm{x}^{*}$ & $\mathrm{x}^{*}$ & $\mathrm{x}$ & $\mathrm{x}$ & $\mathrm{x}$ & - \\
\hline $13 \mathrm{c}$ & $\mathrm{x}^{*}$ & $\mathrm{x}^{*}$ & $\mathrm{x}$ & $\mathrm{x}$ & - & - \\
\hline $13 \mathrm{~d}$ & $\mathrm{x}^{*}$ & $\mathrm{x}^{*}$ & $\mathrm{x}$ & - & - & - \\
\hline $13 \mathrm{e}$ & $\mathrm{x}^{*}$ & $\mathrm{x}^{*}$ & - & - & - & - \\
\hline $14 a$ & $\mathrm{x}^{*}$ & $x$ & $\mathrm{x}$ & $\mathrm{x}^{*}$ & $\mathrm{x}$ & $\mathrm{x}$ \\
\hline $14 b$ & $\mathrm{x}^{*}$ & $\mathrm{x}$ & $\mathrm{x}$ & $\mathrm{x}^{*}$ & $\mathrm{x}$ & \\
\hline $14 \mathrm{c}$ & $\mathrm{x}^{*}$ & $\mathrm{x}$ & $x$ & $\mathrm{x}^{*}$ & - & - \\
\hline $14 \mathrm{~d}$ & $\mathrm{x}^{*}$ & - & $\mathrm{x}$ & $\mathrm{x}^{*}$ & - & - \\
\hline $15 \mathrm{a}$ & $\mathrm{x}^{*}$ & $\mathrm{x}$ & $\mathrm{x}^{*}$ & $x$ & $\mathrm{x}$ & $\mathrm{x}$ \\
\hline $15 b$ & $\mathrm{x}^{*}$ & $x$ & $\mathrm{x}^{*}$ & - & $\mathrm{x}$ & $\mathrm{x}$ \\
\hline $15 \mathrm{c}$ & $\mathrm{x}^{*}$ & $\mathrm{x}$ & $\mathrm{x}^{*}$ & - & $x$ & - \\
\hline $15 \mathrm{~d}$ & $\mathrm{x}^{*}$ & $\mathrm{x}$ & $\mathrm{x}^{*}$ & - & - & - \\
\hline $15 \mathrm{e}$ & $x^{*}$ & - & $x^{*}$ & - & - & - \\
\hline
\end{tabular}


were standardized by row, where weights were divided by the row sum (style=W). Since spatial autocorrelation was detected, we calculated the effective sample size $\left(\mathrm{n}_{\mathrm{eff}}=\mathrm{n} /(1+\right.$ absolute Moran's I statistic estimate $\left.)\right)$ and adjusted the AICc values for all top models, adjusted AICc values $\mathrm{AICc}_{\mathrm{adj}}=\left(\mathrm{AIC}+\left((2 \mathrm{~K}(\mathrm{~K}+1)) / \mathrm{n}_{\text {eff }}-\mathrm{K}-1\right)\right)$ and adjusted summary statistics for predictors in the best deviation from expected model and storm surge submodel.

\section{Statistical Programs and Packages Used}

All analyses were conducted and graphics were created using R version 3.3.1 (R Core Team, 2016) and ArcGIS 10.4. The following $\mathrm{R}$ packages were used during data formatting: reshape 2 (Wickham, 2007), plyr (Wickham, 2014), and data.table (Dowle and others, 2015).

\section{Results}

\section{Correlation Between Predictor Variables}

The VIF values, using eligible SET data, were less than three for all predictors in both the deviation from expected and storm surge models (table 7). SETs with eligible surface elevation data were graphed in bivariate plots showing the relations between pairs of predictor variables (fig. 7): distance to storm landfall (fig. $7 A-C$ ), geomorphic setting (fig. $7 C, E, F$ ), position relative to storm landfall (fig. $7 C$ ), rate of prestorm elevation change (fig. 7A, D,E), and coefficient of variation $(\mathrm{CV})$ in prestorm data (fig. $7 B, D, F$ ). SET stations within back-barrier lagoonal settings to the right of landfall had a much greater range in distance from landfall, where this category contained both the closest and furthest away SET stations, compared to stations to the left of landfall and in estuarine settings (fig. 7C). Similarly, the range in $\mathrm{CV}$ in the prestorm elevation change trend was greater in the back-barrier lagoonal setting

Table 6. Storm surge submodels. Predictors include distance to storm landfall (kilometers/1,000; distance), geomorphic setting, and position relative to landfall.

[-, no data; *, indicates a two-way interaction between variables]

\begin{tabular}{cccc}
\hline Model & Distance & $\begin{array}{c}\text { Geomorphic } \\
\text { setting }\end{array}$ & $\begin{array}{c}\text { Position } \\
\text { relative to } \\
\text { landfall }\end{array}$ \\
\hline $1 \mathrm{a}$ & $\mathrm{x}$ & - & - \\
\hline 2 & $\mathrm{x}$ & $\mathrm{x}$ & - \\
\hline 3 & $\mathrm{x}$ & - & $\mathrm{x}$ \\
\hline 4 & $\mathrm{x}^{*}$ & $\mathrm{x}^{*}$ & - \\
\hline 5 & $\mathrm{x}^{*}$ & - & $\mathrm{x}^{*}$ \\
\hline
\end{tabular}

compared to the estuarine setting (fig. $7 F$ ). The other bivariate comparisons revealed no important relations (fig. $7 A, B, D, E$ ).

\section{Distribution of SET-MH Stations Used in Effects Analysis}

A number of factors contribute to the distribution of sampling in large spatial datasets, resulting in uneven dispersion of replicates among geographic and geomorphic settings. In this study some of these spatial factors include the opportunistic nature of the SET-MH network, the distribution of geomorphic settings along the east coast from Virginia to Maine, and the location of Hurricane Sandy landfall (fig. 8). The distribution of eligible SET stations between geomorphic settings, position relative to storm landfall, and distance from storm landfall (table 4 and fig. $8 C$ ) show that the majority of stations within back-barrier lagoonal marsh (BBL) were located to the right of landfall (78 percent), and the majority of stations within estuarine marsh were located to the left of landfall (73 percent). SET stations occur from $8 \mathrm{~km}$ to as much as $557 \mathrm{~km}$ from the storm landfall (table 4).

\section{Deviation from Expected Surface Elevation Change Model}

The model with a quadratic curve had the lowest AICc value $(1,758.71)$ for predicting the relation between deviation from expected surface elevation change and distance from storm landfall. The model with a linear curve was greater than two points from this $\mathrm{AICc}_{\min }$ model $(\triangle \mathrm{AICc}=21.34$; table 8$)$. Therefore, the quadratic distance curve was included in all deviation from expected elevation models.

Three of 46 models had a $\triangle \mathrm{AICc}$ less than 2 from the $\mathrm{AICc}_{\text {min }}$ model (table 9) for predicting the deviation from expected surface elevation change. The simplest model was

Table 7. Results from variance inflation factor (VIF) analysis assessing the colinearity between predictor variables in the deviation from expected surface elevation model and the storm surge submodel. VIF $>3$ indicates high colinearity.

[>, greater than; na, not applicable]

\begin{tabular}{lcc}
\hline \multicolumn{1}{c}{ Predictor } & \multicolumn{2}{c}{$\begin{array}{c}\text { Variance inflation } \\
\text { factor values }\end{array}$} \\
\cline { 2 - 3 } & $\begin{array}{c}\text { Surface } \\
\text { elevation } \\
\text { model }\end{array}$ & $\begin{array}{c}\text { Storm } \\
\text { surge } \\
\text { submodel }\end{array}$ \\
\hline Distance from storm landfall & 2.16 & 2.02 \\
\hline Geomorphic setting & 1.66 & 2.21 \\
\hline Position relative to storm landfall & 1.75 & 2.13 \\
Exposure to storm surge & 2.18 & na \\
\hline Rate of pre-Sandy elevation change & 1.09 & na \\
\hline Coefficient of variation in pre-Sandy record & 1.04 & na \\
\hline
\end{tabular}



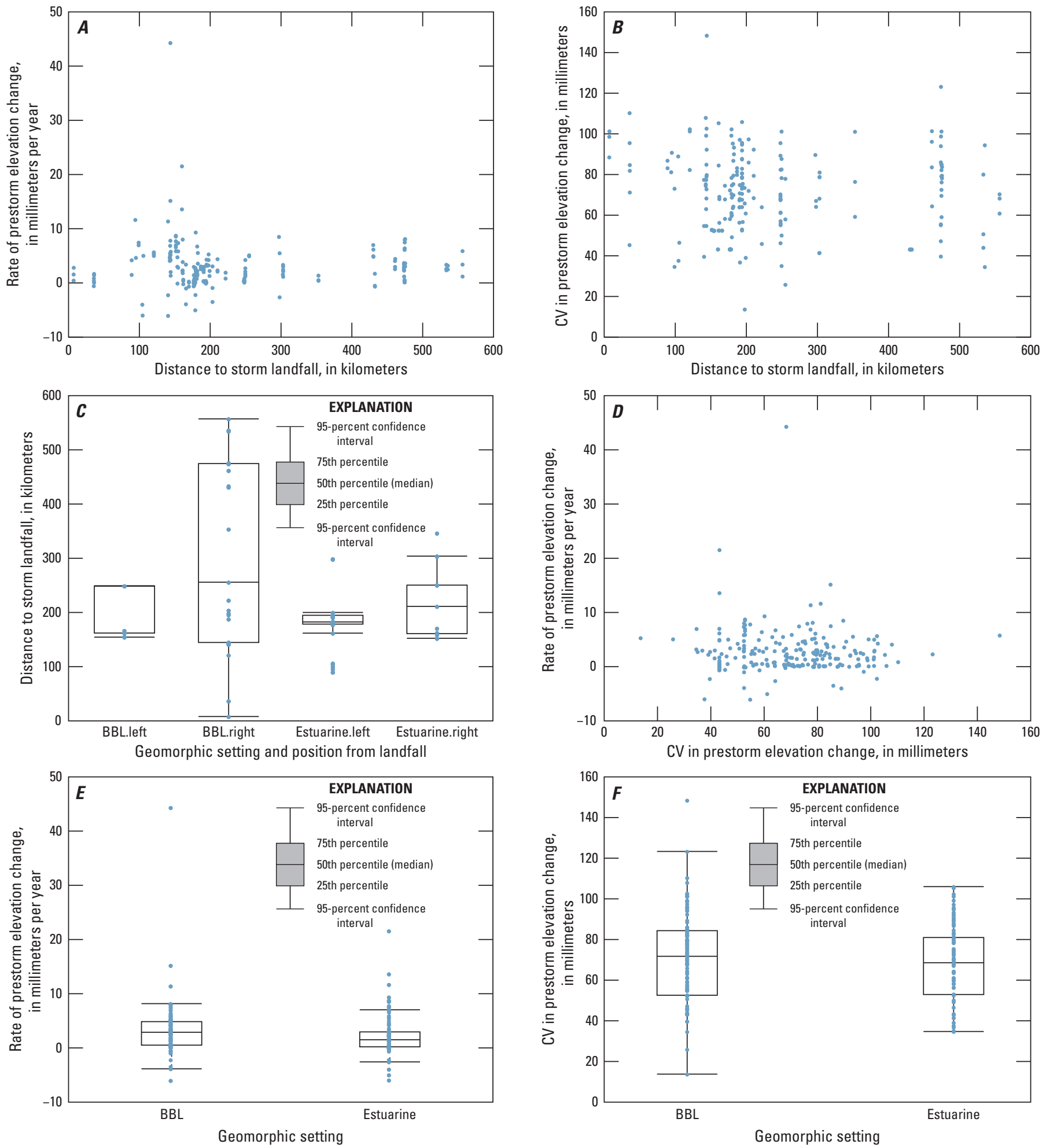

Figure 7. Bivariate relations between predictor variables in the eligible total surface elevation dataset. Relations between distance from storm landfall and $A$, rate of prestorm surface elevation change, $B$, coefficient of variation (CV) in prestorm surface elevation change, and $C$, geomorphic setting and position relative to landfall categories. Relations between $D, C V$ in prestorm surface elevation change and rate of prestorm surface elevation change, and between geomorphic setting and $E$, rate of prestorm surface elevation change, and $F, C V$ in prestorm surface elevation change. Geomorphic setting categories include back-barrier lagoonal marsh (BBL) and estuarine marsh (Estuarine). Position categories include left and right of landfall. 
$\boldsymbol{A}$

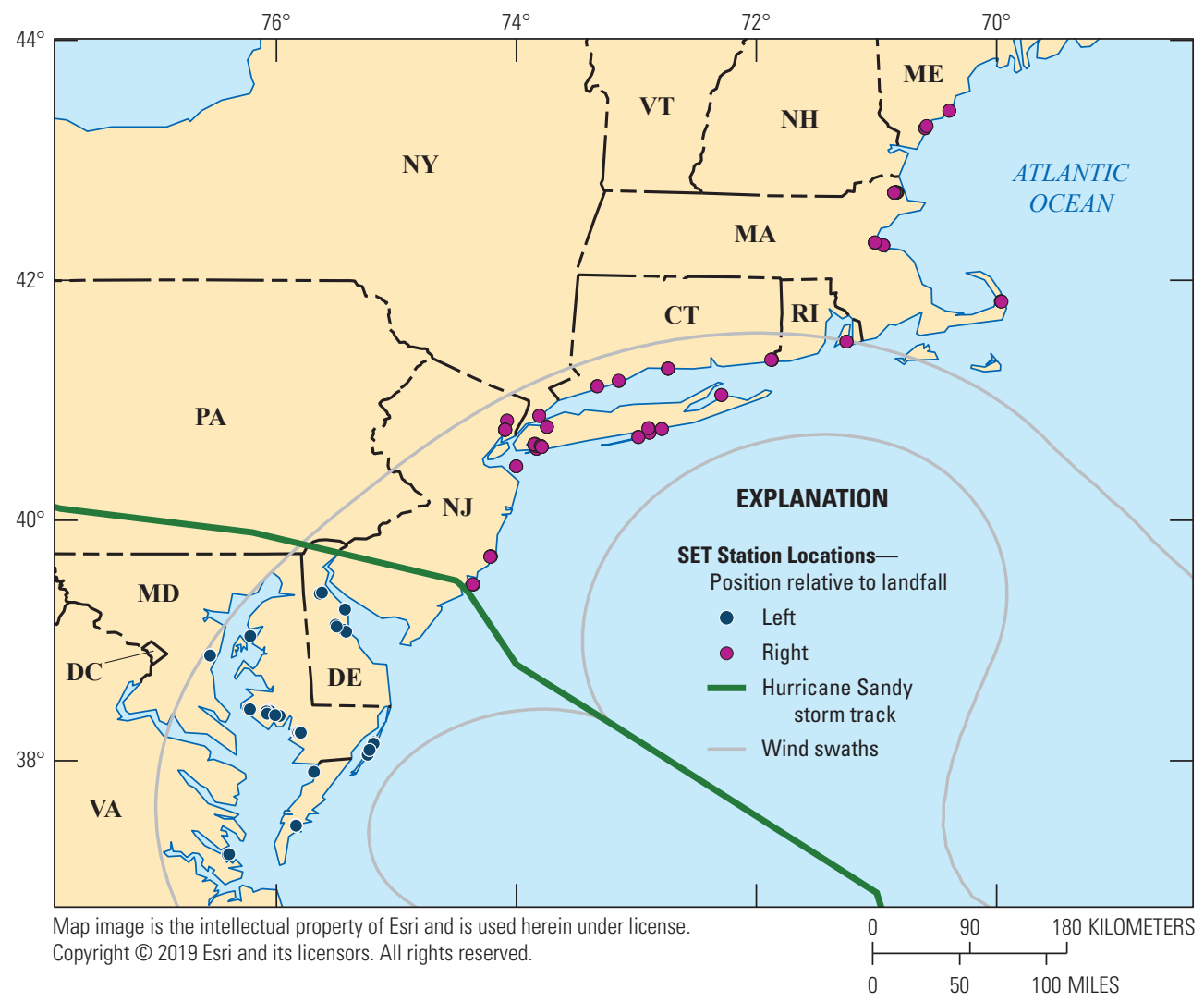

$\boldsymbol{B}$

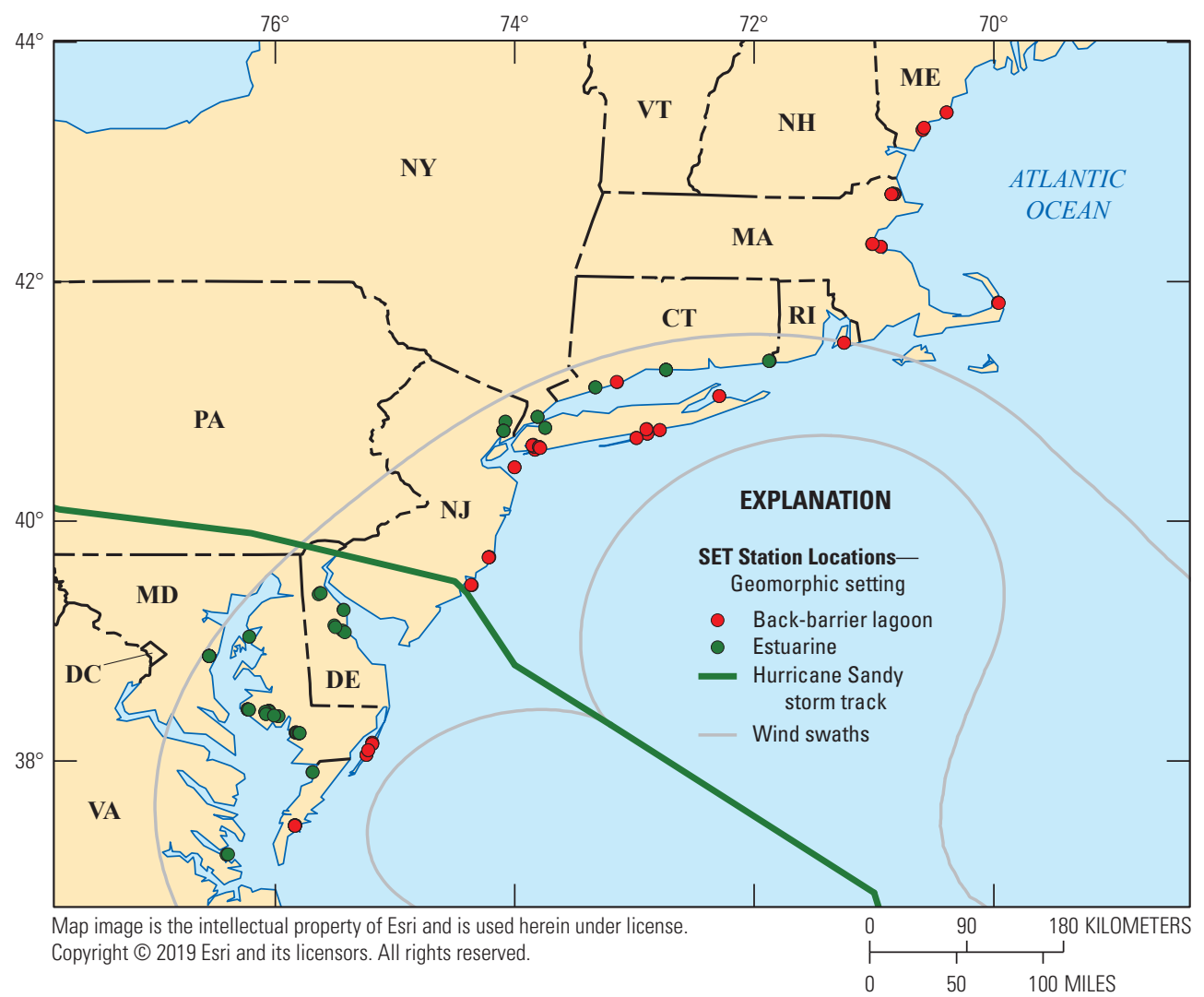

Figure 8. Study region showing storm track, wind swaths (34 and 64 knots), and stations with eligible surface elevation table (SET) data in each category: $A$, position relative to landfall (left or right), $B$, geomorphic setting, and $C$, storm surge. Storm track and wind swath shapefiles from the National Oceanic and Atmospheric Administration (2014). 
C

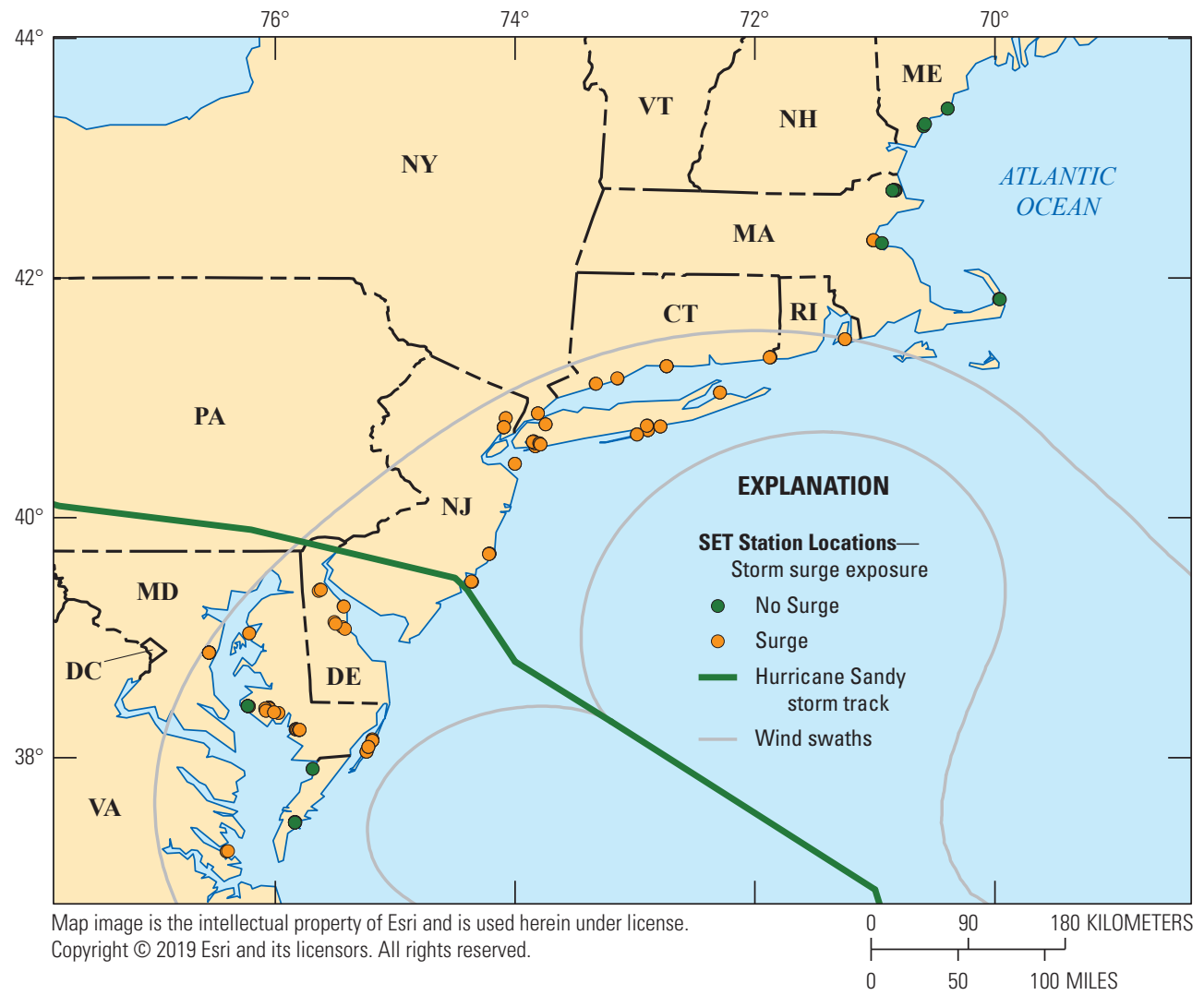

Figure 8. Study region showing storm track, wind swaths ( 34 and 64 knots), and stations with eligible surface elevation table (SET) data in each category: $A$, position relative to landfall (left or right), $B$, geomorphic setting, and $C$, storm surge. Storm track and wind swath shapefiles from the National Oceanic and Atmospheric Administration (2014).-Continued

Table 8. Comparing distance from storm landfall curves (linear and quadratic) in the deviation from expected surface elevation model and storm surge submodel using Akaike's Information Criterion, AICc.

$[\Delta$, change in]

\begin{tabular}{|c|c|c|c|c|}
\hline Response & Predictor & AICc & $\triangle \mathrm{AICC}$ & Weight \\
\hline \multirow{2}{*}{ Deviation from expected elevation change } & Distance + distance $^{2}$ & $1,758.71$ & 0 & 1 \\
\hline & Distance & $1,780.05$ & 21.34 & 0 \\
\hline Storm surge & Distance & 145.04 & 0 & 0.62 \\
\hline
\end{tabular}

model 15e, which consisted of an interaction between distance from and position relative to landfall with no other predictors (table 5). See table 3.1 in appendix 3 for model summary information and figure 9 for model predicted versus response plot. Model 15e was determined to be the best model available for predicting deviation from expected surface elevation change following Hurricane Sandy.

As deviation from the expected surface elevation change trend was spatially autocorrelated $(P<0.001, \mathrm{SD}=7.89)$, we calculated effective sample size and used this to calculate an adjusted AICc value for the three top models (table 10). Although the $\triangle \mathrm{AICc}$ based on the adjusted values ( $\triangle \mathrm{AICc}$ for model $15 \mathrm{c}=0.625$ and model $15 \mathrm{e}=0.633$ ) differed from the unadjusted values ( $\triangle \mathrm{AICc}=0.67$ and 0.681 , respectively), the order did not change.

Parameter estimates from model 15e (best model) indicate that within $200 \mathrm{~km}$ from storm landfall there was a greater negative deviation from the expected elevation change trend (elevation loss) and a greater effect of distance to landfall in stations to the right of landfall than to the left (fig. 10; table 3.1 in appendix 3).

Owing to yearly variation among surveys, we expected that poststorm measurements would exhibit some deviation from the expected change trend, irrespective of hurricane influence. Prestorm mean residual distance and poststorm residual distance from the prestorm trend line were less than or equal to $\pm 5 \mathrm{~mm}$ for 89.7 percent and 62.8 percent of eligible SET stations, respectively, indicating greater variation in the residual distance (in other words, exceeding $\pm 5 \mathrm{~mm}$ ) poststorm (fig. 11). Of the 223 eligible SET stations, there were 125 stations (56.1 percent) with a deviation greater than expected (elevation gain) and 98 stations (43.9 percent) with a deviation less than expected (elevation loss; fig. 11A). Based on these distributions, we suggest that a deviation of greater 
Table 9. Deviation from expected surface elevation change models ranked by corrected Akaike's Information Criteria (AICc). Models with small AICc values are considered higher quality, and models with an AICc difference of less than 2 ( $\triangle \mathrm{AIC} C<2$ ) are considered equivalent (shaded blue). Of these equivalent models, the simplest model is indicated by an * and considered the best (model 15e). Model details are listed in table 4. The number of estimated parameters $(\mathrm{K})$ indicates model complexity and is used to calculate AICc. Weights indicate the normalized model likelihoods (sum to 1).

$[\Delta$, change in $]$

\begin{tabular}{|c|c|c|c|c|c|c|}
\hline Model & $\mathbf{K}$ & AICc & $\triangle \mathrm{AICC}$ & AICc weight & Cumulative weight & Log Likelihood \\
\hline $15 \mathrm{~d}$ & 7 & $1,749.13$ & 0 & 0.27 & 0.27 & -867.3 \\
\hline $15 \mathrm{c}$ & 8 & $1,749.65$ & 0.52 & 0.21 & 0.48 & -866.49 \\
\hline * $15 \mathrm{e}$ & 6 & $1,749.78$ & 0.65 & 0.19 & 0.67 & -868.69 \\
\hline $7 \mathrm{~d}$ & 7 & $1,751.33$ & 2.2 & 0.09 & 0.76 & -868.4 \\
\hline $15 b$ & 9 & $1,751.41$ & 2.28 & 0.09 & 0.85 & -866.28 \\
\hline $7 \mathrm{c}$ & 8 & $1,752.78$ & 3.65 & 0.04 & 0.89 & -868.06 \\
\hline $15 \mathrm{a}$ & 10 & $1,753.54$ & 4.41 & 0.03 & 0.92 & -866.25 \\
\hline $7 b$ & 9 & $1,754.04$ & 4.91 & 0.02 & 0.94 & -867.6 \\
\hline $7 \mathrm{a}$ & 10 & $1,755.86$ & 6.73 & 0.01 & 0.95 & -867.41 \\
\hline $14 \mathrm{c}$ & 8 & $1,757.5$ & 8.37 & 0 & 0.96 & -870.41 \\
\hline $14 d$ & 7 & $1,757.79$ & 8.66 & 0 & 0.96 & -871.63 \\
\hline $10 \mathrm{~d}$ & 7 & $1,757.88$ & 8.75 & 0 & 0.96 & -871.68 \\
\hline 2 & 5 & $1,758.2$ & 9.07 & 0 & 0.96 & -873.96 \\
\hline 3 & 6 & $1,758.5$ & 9.37 & 0 & 0.97 & -873.05 \\
\hline $12 \mathrm{c}$ & 8 & $1,758.63$ & 9.5 & 0 & 0.97 & -870.98 \\
\hline $10 \mathrm{c}$ & 8 & $1,758.68$ & 9.55 & 0 & 0.97 & -871 \\
\hline $12 \mathrm{~d}$ & 7 & $1,758.72$ & 9.59 & 0 & 0.97 & -872.1 \\
\hline $14 \mathrm{~b}$ & 9 & $1,758.79$ & 9.66 & 0 & 0.98 & -869.97 \\
\hline 4 & 7 & $1,758.86$ & 9.73 & 0 & 0.98 & -872.17 \\
\hline $10 \mathrm{e}$ & 6 & $1,758.87$ & 9.74 & 0 & 0.98 & -873.24 \\
\hline $12 \mathrm{~b}$ & 9 & $1,758.94$ & 9.81 & 0 & 0.98 & -870.05 \\
\hline $1 b$ & 4 & $1,759.17$ & 10.04 & 0 & 0.98 & -875.49 \\
\hline $13 \mathrm{e}$ & 6 & $1,759.38$ & 10.25 & 0 & 0.99 & -873.5 \\
\hline $12 \mathrm{e}$ & 6 & $1,759.38$ & 10.25 & 0 & 0.99 & -873.5 \\
\hline $13 d$ & 7 & $1,759.67$ & 10.54 & 0 & 0.99 & -872.57 \\
\hline $10 \mathrm{~b}$ & 9 & $1,759.8$ & 10.67 & 0 & 0.99 & -870.48 \\
\hline $13 \mathrm{c}$ & 8 & $1,760.04$ & 10.91 & 0 & 0.99 & -871.68 \\
\hline 5 & 8 & $1,760.14$ & 11.01 & 0 & 0.99 & -871.73 \\
\hline $11 \mathrm{~d}$ & 7 & $1,760.42$ & 11.29 & 0 & 0.99 & -872.95 \\
\hline $10 \mathrm{a}$ & 10 & $1,760.59$ & 11.46 & 0 & 0.99 & -869.77 \\
\hline $14 a$ & 10 & $1,760.6$ & 11.47 & 0 & 0.99 & -869.78 \\
\hline $11 \mathrm{c}$ & 8 & $1,760.78$ & 11.65 & 0 & 1 & -872.05 \\
\hline $12 \mathrm{a}$ & 10 & $1,761.06$ & 11.93 & 0 & 1 & -870.01 \\
\hline $13 b$ & 9 & $1,761.18$ & 12.05 & 0 & 1 & -871.17 \\
\hline $11 \mathrm{~b}$ & 9 & $1,762.09$ & 12.96 & 0 & 1 & -871.62 \\
\hline $8 \mathrm{c}$ & 8 & $1,762.19$ & 13.06 & 0 & 1 & -872.76 \\
\hline 6 & 9 & $1,762.28$ & 13.15 & 0 & 1 & -871.72 \\
\hline $8 \mathrm{~b}$ & 9 & $1,762.5$ & 13.37 & 0 & 1 & -871.83 \\
\hline $13 a$ & 10 & $1,763.33$ & 14.2 & 0 & 1 & -871.14 \\
\hline $9 \mathrm{c}$ & 8 & $1,763.68$ & 14.55 & 0 & 1 & -873.5 \\
\hline $11 \mathrm{a}$ & 10 & $1,763.77$ & 14.64 & 0 & 1 & -871.37 \\
\hline $8 \mathrm{a}$ & 10 & $1,763.85$ & 14.72 & 0 & 1 & -871.41 \\
\hline $8 d$ & 7 & $1,763.87$ & 14.74 & 0 & 1 & -874.68 \\
\hline $9 \mathrm{~b}$ & 9 & $1,763.89$ & 14.76 & 0 & 1 & -872.52 \\
\hline $9 d$ & 7 & $1,763.95$ & 14.82 & 0 & 1 & -874.71 \\
\hline $9 \mathrm{a}$ & 10 & $1,764.4$ & 15.27 & 0 & 1 & -871.68 \\
\hline
\end{tabular}




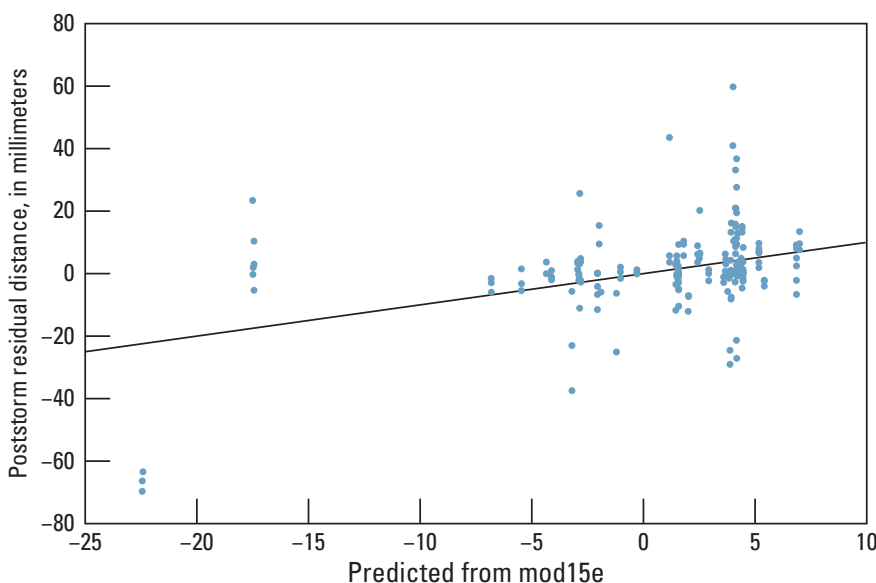

Figure 9. Model prediction versus response for the best deviation from expected surface elevation model (15e).

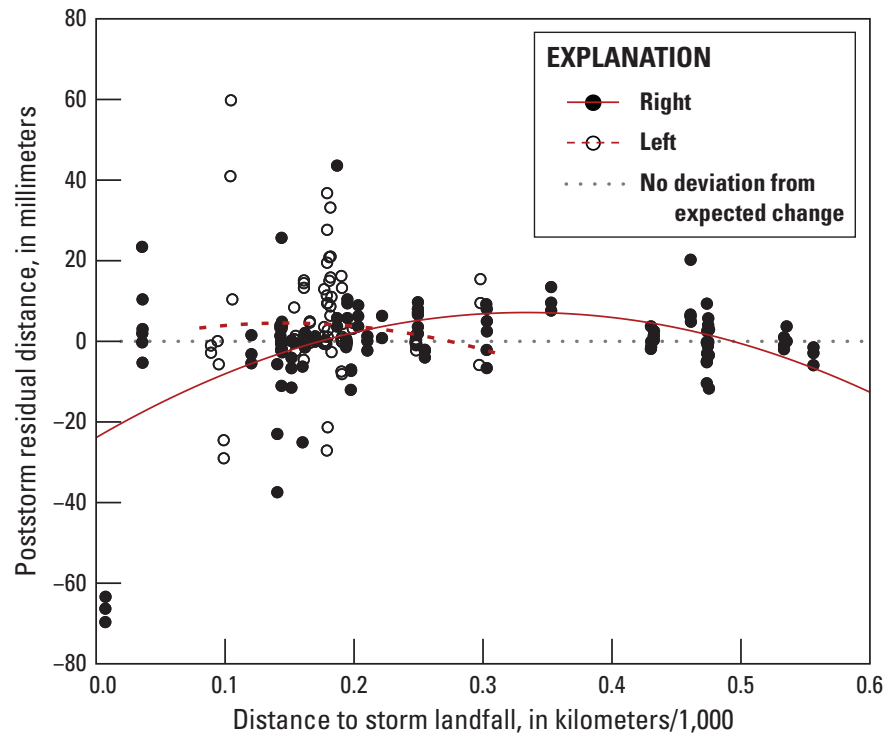

Figure 10. Poststorm deviation from expected surface elevation change along the distance to storm landfall gradient (kilometers/1,000). Lines are parameter estimates, from the best model (model 15e), for stations to the right (closed circle, solid line) and left (open circle, dashed line) of storm landfall. Dotted grey line indicates no deviation from expected change. Only eligible surface elevation data are displayed and used in analysis (223 surface elevation table stations).

than $5 \mathrm{~mm}$ from expected is more likely to indicate an effect of Hurricane Sandy on the rate of elevation change than a deviation of less than $5 \mathrm{~mm}$. If we look at the stations with a greater than $5 \mathrm{~mm}$ deviation from expected, we find that stations to the left of landfall were more likely to experience a greater than expected elevation change (27 stations; 77.1 percent) than a less than expected change (8 stations; 22.9 percent; fig. $12 \mathrm{~A}$; table 11). This trend was also evident in the range and mean deviation from expected values exhibited to the left of landfall (range $=-28.8$ to $60.0 \mathrm{~mm}$; mean loss $=-15.9 \pm 3.6 \mathrm{~mm}$; mean gain $=18.0 \pm 2.4 \mathrm{~mm}$; table 11 ). This suggests elevation gain was more prevalent than elevation loss in stations located to
Table 10. Effective sample sizes $\left(\mathrm{n}_{\text {eff }}\right)$ for all top models. Of these equivalent models the simplest model is indicated by an * and considered the best (model 15e). Model details are listed in table $4 . K=$ number of estimated parameters, and $n=223$ surface elevation tables stations.

[AICc ${ }_{\text {adj }}$, corrected Akaike's Information Criteria; $\Delta$, change in]

\begin{tabular}{rcccl}
\hline Model & $\mathbf{K}$ & $\mathbf{n}_{\text {eff }}$ & AICc $_{\text {adj }}$ & $\Delta \mathbf{A I C c}_{\text {adj }}$ \\
\hline \multicolumn{5}{c}{ Deviation from expected surface elevation } \\
\hline $15 \mathrm{~d}$ & 7 & 169 & $1,749.31$ & 0 \\
$15 \mathrm{c}$ & 8 & 170 & $1,749.89$ & 0.58 \\
$* 15 \mathrm{e}$ & 6 & 170 & $1,749.90$ & 0.60 \\
\hline \multicolumn{5}{c}{ Storm surge submodel } \\
\hline 3 & 3 & 156 & 95.41 & 0 \\
5 & 4 & 156 & 96.71 & 1.31 \\
\hline
\end{tabular}

the left of landfall. To the right of landfall, the proportion of stations with greater than expected change was similar to those with less than expected change ( 28 stations ( 58.3 percent) and 20 stations (41.7 percent), respectively; fig. $12 B$; table 11 ). Stations to the right tended to experience greater elevation loss (range $=-69.4$ to $43.8 \mathrm{~mm}$; mean loss $=-19.7 \pm 4.8 \mathrm{~mm}$; mean gain $=10.9 \pm 1.6 \mathrm{~mm}$; table 11 ).

Stations with the greatest elevation loss were located to the right of landfall, whereas stations that experienced the greatest elevation gain were to the left of landfall (fig. 12, table 11). The range in deviation from the expected elevation change trend was greater to the right of landfall than to the left (113.2 and $88.8 \mathrm{~mm}$, respectively; table 11). To the right of landfall there were greater negative values (elevation loss) than to the left (minimum $=-69.4$ and $-28.8 \mathrm{~mm}$, respectively), and the maximum positive value (elevation gain) was lower to the right than to the left of landfall (maximum $=43.8$ and $60.0 \mathrm{~mm}$, respectively; fig. 12).

\section{Storm Surge Submodel}

To predict the relation between storm surge and distance from storm landfall, the model that assumed a linear relation between response and predictor variables had the lowest AICc value (145.04). Even though the model containing the quadratic relation had a $\triangle \mathrm{AICc}$ less than two $(\triangle \mathrm{AICc}=0.94$; table 8 ), the linear relation was included in all storm surge submodels.

Two of five models had a $\triangle A I C c$ less than two from the $\mathrm{AICc}_{\min }$ model (table 12) for predicting presence of storm surge. The simplest model was submodel 3 , which consisted of distance from, and position relative to, landfall with no interaction (table 6). See table 3.2 in appendix 3 for model summary information. Submodel 3 was therefore considered the best model available for predicting storm surge presence during Hurricane Sandy.

We calculated effective sample size and used this to calculate an adjusted AICc value for the two models with 

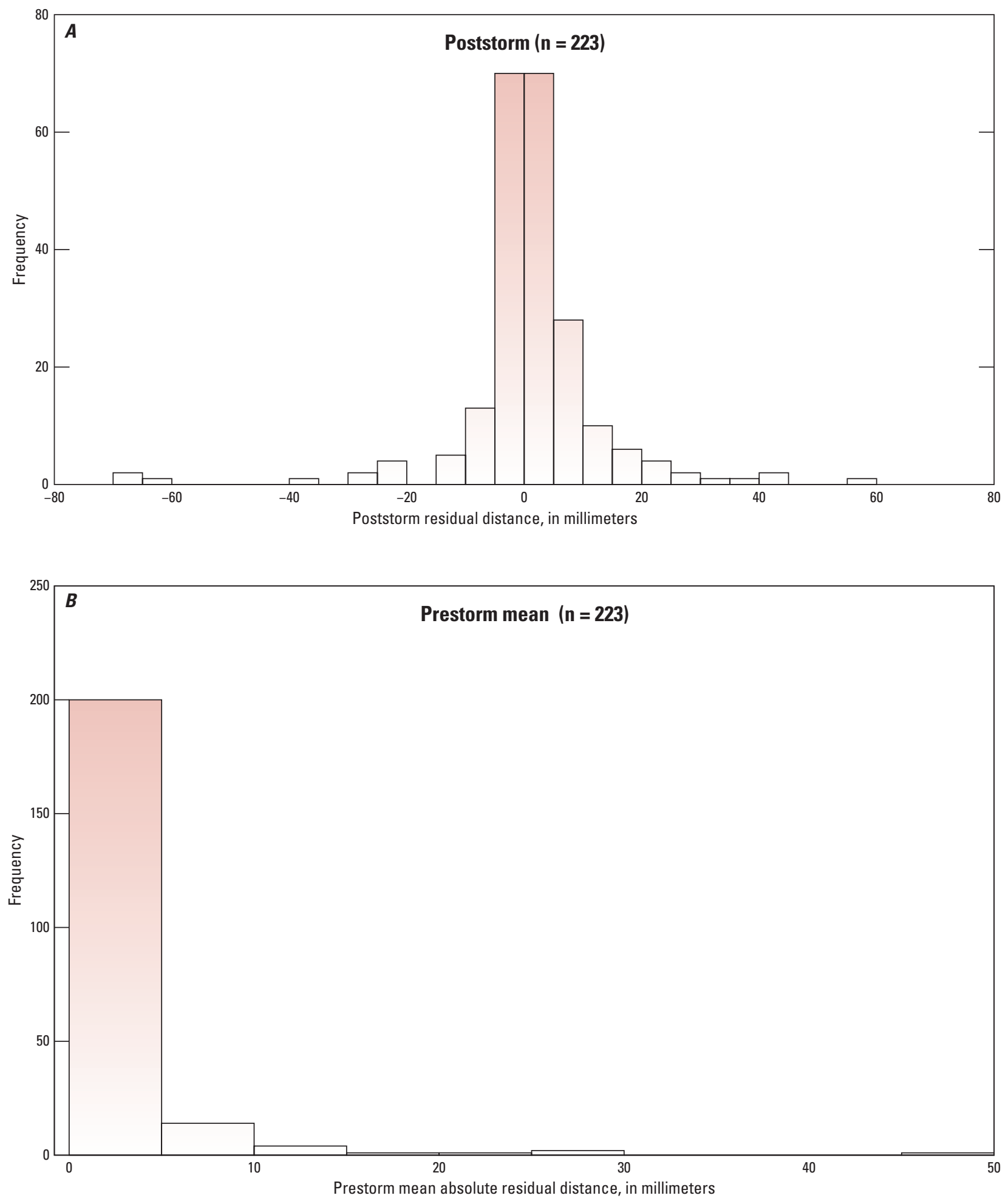

Figure 11. Frequency distribution of $A$, poststorm residual distance from expected (millimeters, \pm ) and $B$, prestorm mean residual distance (millimeters, absolute) using all eligible surface elevation table data.

(n, number of surface elevation table-marker horizon stations) 

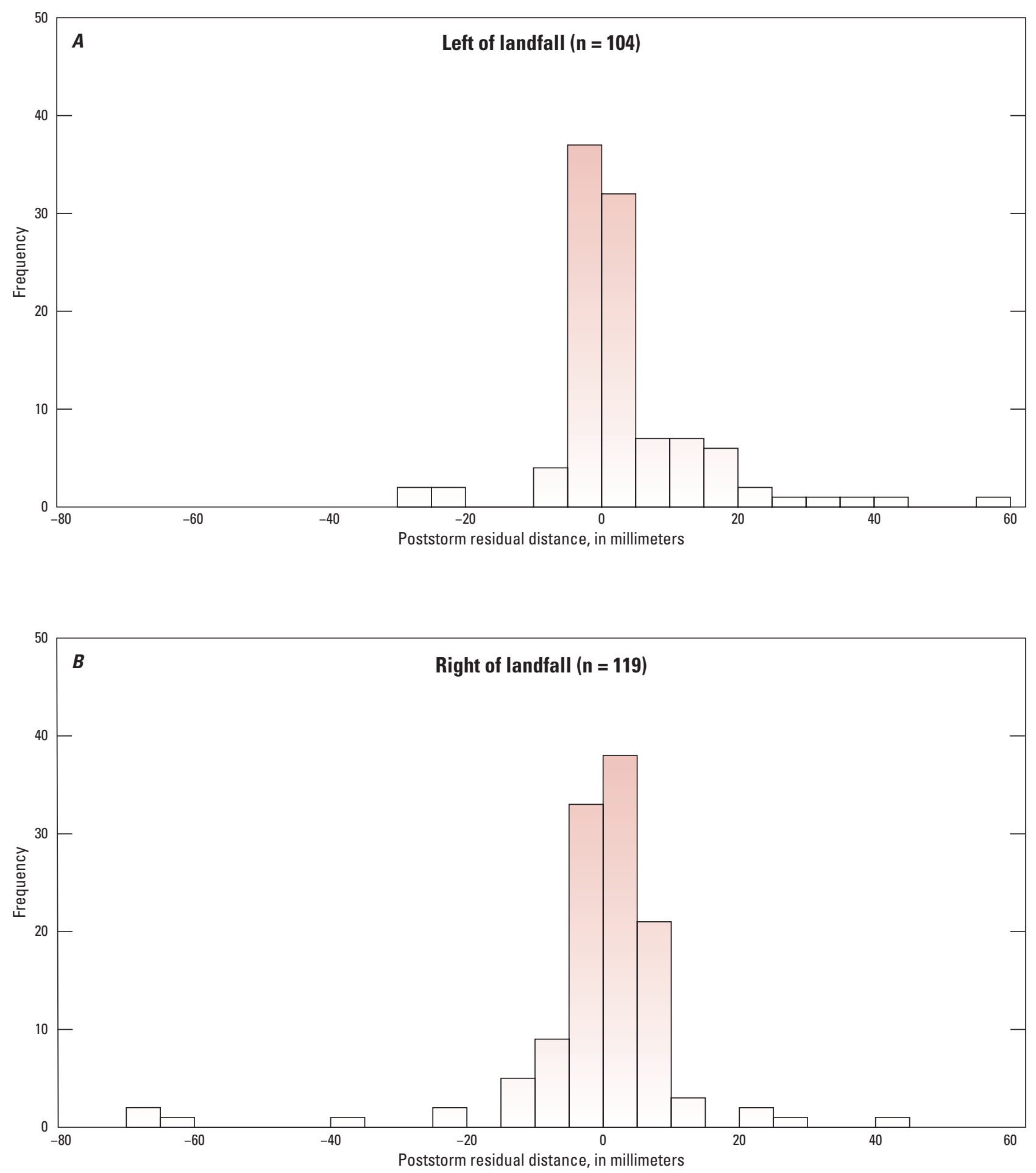

Figure 12. Frequency distribution of poststorm residual distance from expected for eligible surface elevation table stations to the $A$, left and $B$, right of landfall.

(n, number of surface elevation table-marker horizon stations) 
Table 11. Summary information for stations with a deviation from expected elevation change greater than \pm 5 millimeters. Number of stations (n) with elevation gain and loss in each position relative to landfall category (all stations, left, right) and presence or absence of storm surge, along with the maximum value, mean, and standard error (SE) are included.

\begin{tabular}{ccccc}
\hline \multirow{2}{*}{ Position } & $\begin{array}{c}\text { Direction of } \\
\text { elevation effect }\end{array}$ & $\begin{array}{c}\mathbf{n} \\
\text { (percent) }\end{array}$ & $\begin{array}{c}\text { Maximum deviation } \\
\text { (in millimeters) }\end{array}$ & $\begin{array}{c}\text { Mean } \pm \text { SE } \\
\text { (in millimeters) }\end{array}$ \\
\cline { 2 - 5 } All & Gain & $55(66.3)$ & 60.0 & $14.4 \pm 1.5$ \\
& Loss & $28(33.7)$ & -69.4 & $-18.6 \pm 3.6$ \\
\cline { 2 - 5 } Left & Gain & $27(77.1)$ & 60.0 & $18.0 \pm 2.4$ \\
\cline { 2 - 5 } & Loss & $8(22.9)$ & -28.8 & $-15.9 \pm 3.6$ \\
\multirow{2}{*}{ Right } & Gain & $28(58.3)$ & 43.8 & $10.9 \pm 1.6$ \\
\cline { 2 - 5 } Storm surge & Loss & $20(41.7)$ & -69.4 & $-19.7 \pm 4.8$ \\
& Gain & $103(58.9)$ & 60.0 & $-7.9 \pm 1.0$ \\
\hline \multirow{2}{*}{ No storm surge } & Loss & $72(41.1)$ & -69.4 & $4.3 \pm 1.7$ \\
\cline { 2 - 5 } & Gain & $22(45.8)$ & -11.5 & $-2.5 \pm 0.6$ \\
\hline
\end{tabular}

Table 12. Storm surge models ranked by corrected Akaike's Information Criteria (AICc). Models with small AICc values are considered higher quality, and models with an AICc difference of less than 2 ( $\triangle \mathrm{AIC}<<2$ ) are considered equivalent (shaded). Of these equivalent models the simplest model is indicated by an * and considered the best (model 3). Model details are listed in table 5. Number of estimated parameters $(\mathrm{K})$ indicates model complexity. Weights indicate the normalized model likelihoods (sum to 1 ).

$[\Delta$, change in $]$

\begin{tabular}{ccccccc}
\hline Model & K & AICc & $\Delta$ AICc & AICc weight & Cumulative weight & Log likelihood \\
\hline $3^{*}$ & 3 & 95.36 & 0 & 0.65 & 0.65 & -44.62 \\
5 & 4 & 96.63 & 1.27 & 0.35 & -44.22 & 1 \\
2 & 3 & 138.21 & 42.86 & 0 & -66.05 & 1 \\
4 & 4 & 139.65 & 44.29 & 0 & -65.73 & -70.49 \\
\hline
\end{tabular}

the lowest AICc value (table 10). The $\triangle \mathrm{AICc}$ based on the adjusted sample size $(\triangle \mathrm{AICc}=1.31)$ was greater than the unadjusted value $(\triangle \mathrm{AICc}=1.27)$; however, the order did not change (tables 10 and 12).

Based on submodel 3 (best model), the probability that a station was exposed to the storm surge was predicted to decrease with increasing distance from landfall (fig. 13; table 3.2 in appendix 3). Submodel 3 also predicted a shorter distance of influence to the left of landfall than to the right (fig. 13; table 3.2 in appendix 3).

The omission of storm surge from the best deviationfrom-expected-change model may reflect the variation in direction (loss or gain) more than the magnitude of the effect. There were a greater number of eligible SET stations with storm surge present than absent (175 and 48 respectively; fig. 14). The deviation from the expected elevation change trend had both greater positive (elevation gain) and negative (elevation loss) values and greater mean values at stations exposed to the Hurricane Sandy storm surge (range $=-69.4$ to $60.0 \mathrm{~mm}$, mean gain $=7.9 \pm 1.0 \mathrm{~mm}$, mean loss $=-7.5 \pm 1.7 \mathrm{~mm}$ ) than those outside storm surge influence (range $=-11.5$ to $20.4 \mathrm{~mm}$, mean gain $=4.3 \pm 1.1 \mathrm{~mm}$, mean loss $=-2.5 \pm 0.6 \mathrm{~mm}$, table 11). There were a greater percentage of stations within the $\pm 5 \mathrm{~mm}$ deviation from the expected change trend in areas that storm surge was absent from than present (77.1 percent and 58.9 percent, respectively; fig. 14). This suggests that even though storm surge tended to increase the magnitude of deviation from expected it had a complex influence on marsh surface elevation change, resulting in both loss and gain, which may explain the absence of this effect in model selection.

\section{Structural Equation Model Selected for Interpretation}

We used the best deviation-from-expected surface elevation change model and storm surge submodel to create a revised SEM (fig. 15; compare to initial model in fig. 4). Distance from landfall $(-0.71)$ and position relative to landfall $(-0.16)$ were found to explain the likelihood of storm surge presence in the SET data. Observed storm surge presence or absence, however, did not help explain deviation from the expected surface elevation change trend. Rather, deviation from expected elevation change was explained by the interaction between distance from landfall and position relative to landfall (see for example, figs. 10 and 12). Furthermore, geomorphic setting, coefficient of variation in prestorm elevation 
trend, and rate of prestorm elevation trend had no significant effect on the deviation from the expected elevation change.

\section{Discussion}

\section{Spatial Variation in Storm Impacts}

Understanding the impact of Hurricane Sandy on coastal wetland elevation change requires knowledge of both the physical characteristics of the storm and its interaction with coastal landforms it encounters. Our analyses indicate there are important landform differences in coastal geomorphology and wetland setting on either side of the point of landfall at Brigantine, New Jersey. To the right of landfall the predominant wetland type is back-barrier marsh, whereas to the left of it is predominantly estuarine marsh along tidal tributaries of Delaware Bay and Chesapeake Bay. Hurricane Sandy's physical characteristics meant that storm surge area was more extensive right of the landfall in the northeast quadrant of the storm than left of the landfall where winds switched from out of the northwest to out of the southwest during storm approach and passage (Dennison and others, 2012; Middleton, 2016; see fig. 1). This difference in surge dynamics resulted in important differences in wetland impacts to the right and left of the landfall point. The smaller surge area to the left of landfall indicates a shorter distance of surge influence there compared to the right of landfall (fig. 13). To the left of landfall, elevation gain was more prevalent than elevation loss, and the greatest elevation gains for the northeast region were found in these stations. To the right of landfall, stations were located closer to landfall. These stations experienced the greatest elevation loss and range in deviation from expected, and the maximum elevation gains were lower than stations to the left. These effects appear to be the result of the interaction between distance from, and position relative to, landfall as shown in the causal model (fig. 15). This finding is supported by a remotesensing study of Hurricane Sandy's storm surge impact on salt marsh condition (Rangoonwala and others, 2016), where salt marshes located within $20 \mathrm{~km}$ right (north) of landfall experienced high surge persistence and high salt marsh condition change compared to marshes further north of the storm track.

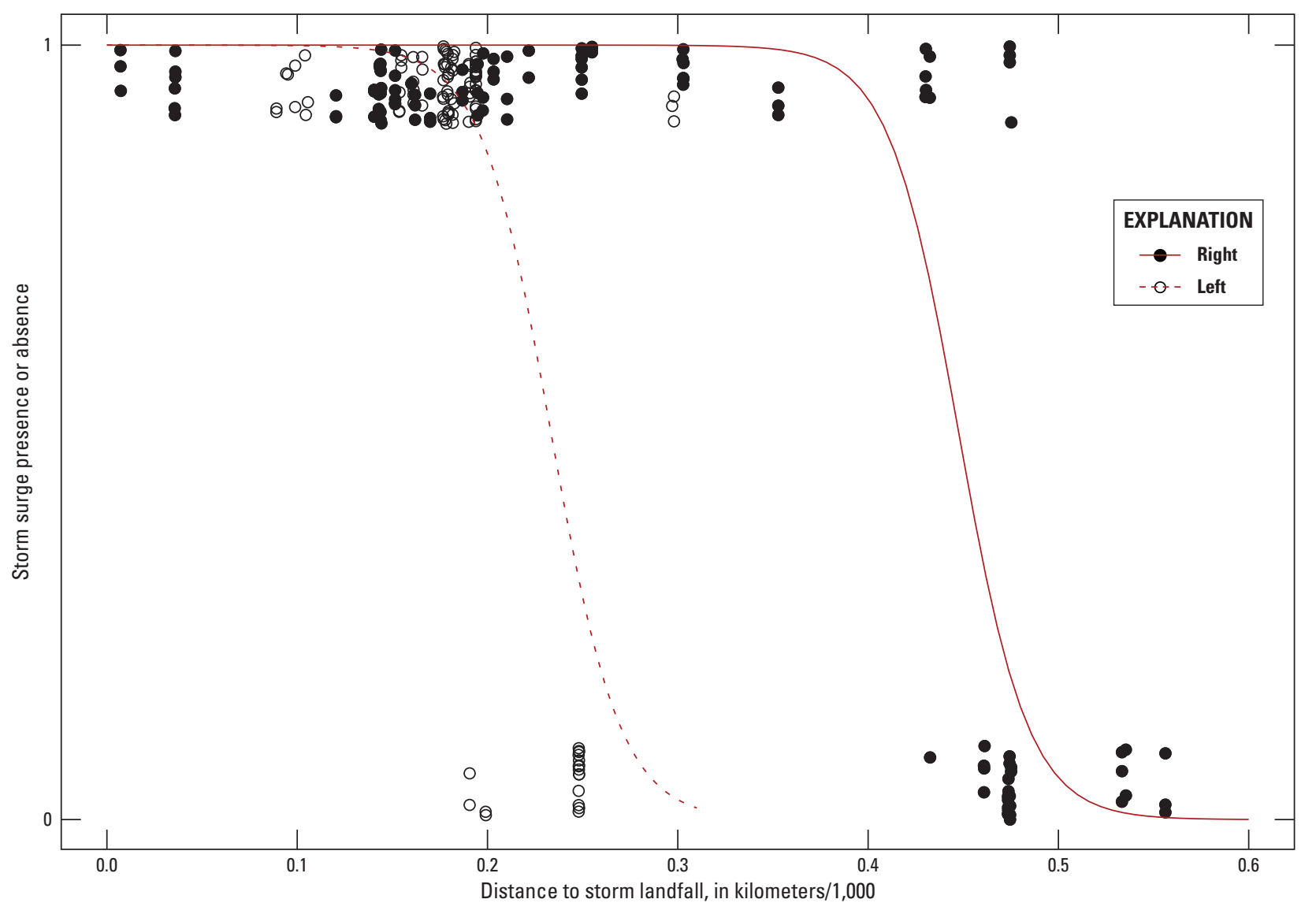

Figure 13. Storm surge presence (1) or absence (0) along the distance from landfall gradient. Lines are parameter estimates, from the best submodel (submodel 3), for stations to the right (closed circle, solid line) and left (open circle, dashed line) of storm landfall. Data and models are based on eligible surface elevation data (223 surface elevation table stations). Points are randomly placed along the vertical axis for visibility of overlapping points. 

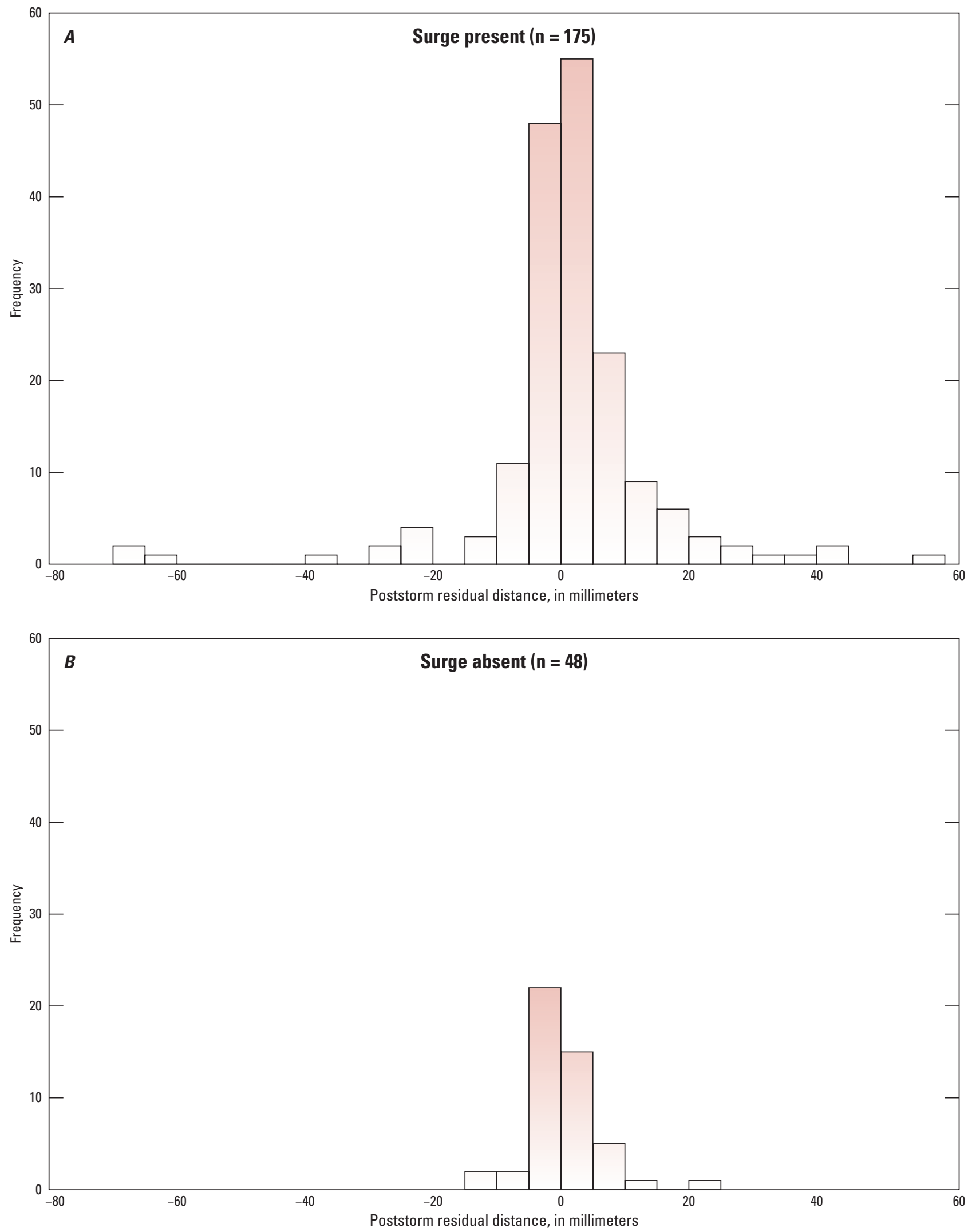

Figure 14. Frequency distribution of poststorm residual distance from expected for eligible surface elevation table stations with storm surge $A$, present and $B$, absent.

(n, number of surface elevation table-marker horizon stations) 


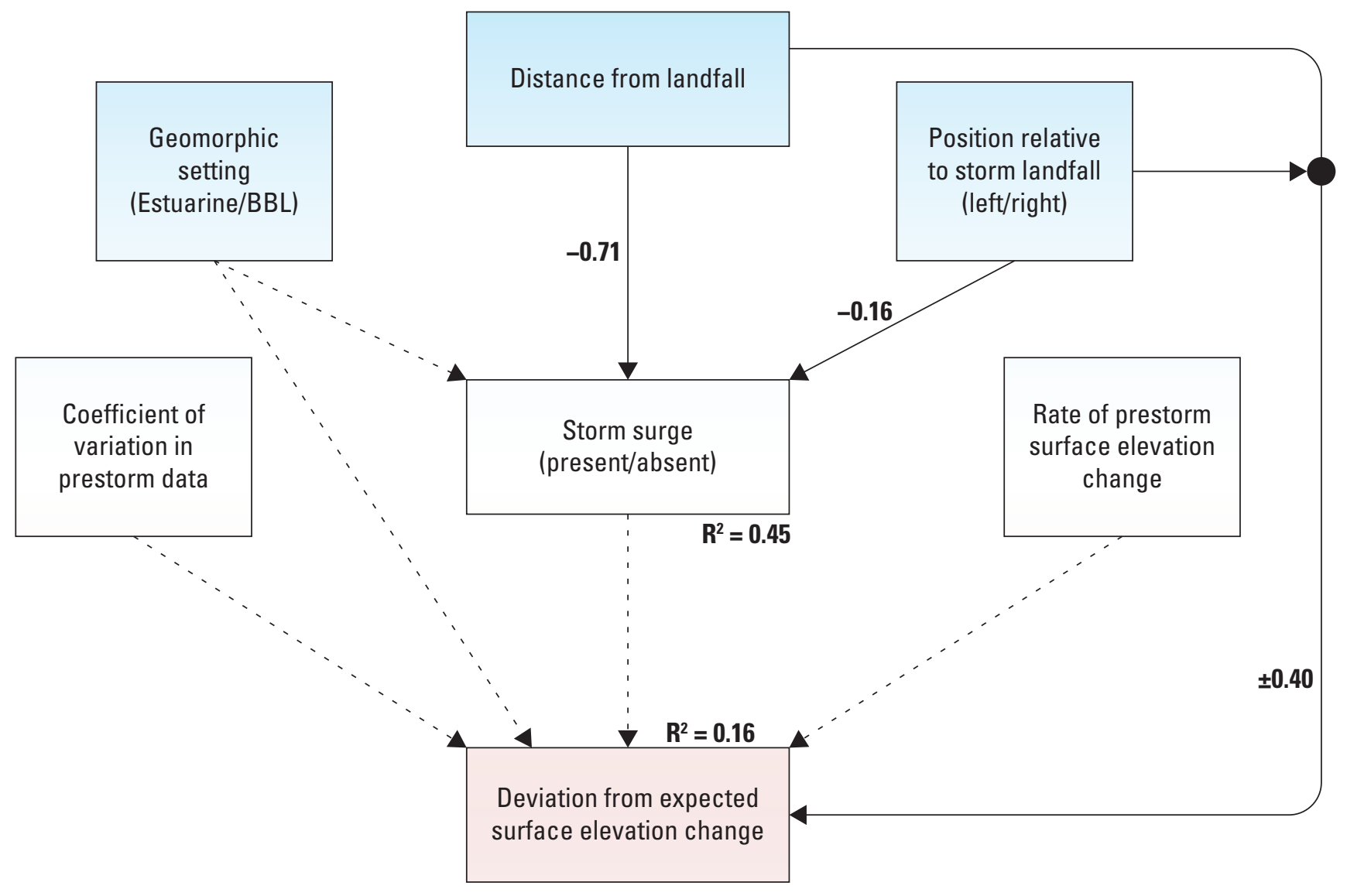

Figure 15. Revised surface elevation model. Solid lines represent pathways among predictors present in the best deviation from expected model (model 15e) and storm surge submodel (submodel 3). Dashed lines represent hypothesized pathways that were not present in the best models. The standardized regression coefficients are reported for noninteracting predictors, and the combined effect is reported for the interaction between predictors.

(R, residual; BBL, back-barrier lagoon)

Rapid assessment of Hurricane Sandy impacts based on qualitative visual observations made in the weeks immediately following the storm revealed low levels of impacts to coastal marshes in general across the northeast region (American Littoral Society, 2012; Grubel and others, 2012; Dennison and others, 2012). For example, along the shores of New Jersey, Long Island Sound, and New York Harbor-Raritan-Jamaica Bays, 14-17 percent of marshes experienced moderate levels of damage, whereas 54-64 percent of marshes experienced low levels of damage (American Littoral Society, 2012). Only a few marshes exhibited high levels of impacts (for example, Little Egg Harbor). Typically, wrack deposits were visible at the marsh upland edge in many back-bay marsh areas but not in the marsh itself. Marsh-edge erosion was observed in some locations (for example, Barnegat Bay marshes located at the point of landfall; Martha Maxwell-Doyle, Barnegat Bay Partnership, oral commun., May 18, 2017), but no quantitative data were available to evaluate its extent across the region. A geographic information system (GIS) analysis of Hurricane Sandy impacts to coastal wetlands of New Jersey revealed that salt marshes were impacted by either erosion or sediment deposition (Hauser and others, 2015). Although such visual observations can be useful, they also can be misleading because they do not account for the storm's influence on subsurface processes such as shallow subsidence or shallow expansion (for example, root zone expansion from enhanced root growth or dilation water storage), which can vary widely among sites and storms and are often the dominant control on elevation change (Cahoon, 2006). For example, compaction by storm surge, when it occurred, ranged from 3 to $33 \mathrm{~mm}$ in a recent review of major storm impacts (Cahoon, 2006).

In an empirical, quantitative evaluation of three marshes in Delaware Bay left of landfall and three marshes in Barnegat Bay right of landfall where SET-MH sampling stations had been established 1.5 years prior to Hurricane Sandy, Quirk (2016) found little evidence of widespread wrack, sediment deposition, or vegetation removal on the marsh surface. Over the poststorm period, surface accretion/erosion was within the range of variability prior to the storm in all six marshes. Surface elevation change over the poststorm period was within the range of variability of prestorm trends for four of the six marshes, with one of the remaining marshes exhibiting significant shallow expansion and the other significant shallow subsidence. Similar storm surge effects on sediment deposition 
processes were observed in 1989 by Gardner and others (1991, 1992) in a South Carolina salt marsh impacted by Hurricane Hugo, a category 4 storm whose approach was perpendicular to the shore. Mud was deposited in the forest located inland of the salt marsh, but not in the marsh itself (Gardner and others, 1991). They hypothesized that the 3- to 4-m-deep surge protected the marsh surface from wind, wave action, and currents. Quirk (2016) also hypothesized that much of the material carried by Hurricane Sandy flood waters passed over the marsh and was deposited along areas of taller structure than marsh grass, such as the upland-forest edge. Indeed, recent investigations using large-scale experimental flumes demonstrate that vegetated marsh surfaces effectively attenuated waves and prevented erosion of the marsh surface during storm surge flooding (Moller and others, 2014; Rupprecht and others, 2017). See Leonardi and others (2018) for a review of the interaction between storm surge and salt marsh vegetation as it relates to surface sedimentation and erosion.

These observations may explain why surface elevation gain was lower and surface elevation loss more likely in marshes located right of landfall, where storm surge was more extensive and strongest during Hurricane Sandy. It is likely there were fewer opportunities for sediment deposition on the marsh surface and more opportunities for compaction of the marsh substrate by the overburden of the 3- to 4-m storm surge compared to marshes located left of landfall. It may also provide insight into why marsh surface elevation gain was more prevalent in the marshes to the left of landfall, where the surge was less extensive and less deep, such as Chesapeake Bay. In Chesapeake Bay, Dennison and others (2012) reported that winds during Hurricane Sandy started from the northwest as the storm approached the mid-Atlantic (blowing water to the south, out of the bay) and transitioned to the southwest as the eye of the storm passed inland north of Chesapeake Bay (fig. 1). The wind shift to the southwest blew water from the west side to the east side of Chesapeake Bay, causing winddriven flooding on the east shore. Thus, deviation from the expected poststorm elevation trend was greater on the east side than the west side of the Chesapeake Bay $(5.4 \pm 1.7 \mathrm{~mm}$ versus $0.7 \pm 0.9 \mathrm{~mm}$ ). Poststorm field observations by Cahoon at Blackwater National Wildlife Refuge (NWR; east side) revealed storm-related sediment deposits on some brackish marsh surfaces along the Blackwater River that flows into Fishing Bay on the east shore of Chesapeake Bay. Apparently, sediment-laden water pushed up into the headwaters of rivers and small bays along the east shore of the bay associated with the $\sim 1 \mathrm{~m}$ surge resulted in more prevalent sediment deposition and elevation gain in those marshes.

These results are consistent with the physical characteristics of Hurricane Sandy, but the range of variation in poststorm residual distance from predicted surface elevation change both left and right of the storm (fig. 12), and in the presence and absence of storm surge (fig. 14), indicates that a combination of factors beyond just the physics of the storm influenced wetland responses. Some of these factors likely include sediment supply, wetland productivity and integrity, wetland elevation relative to mean sea level, and the degree of hydrologic alterations by human activities.

\section{Implications for Marsh Resilience}

The long-term impacts on marsh resilience of a highmagnitude, low-frequency event like Hurricane Sandy are variable and may appear incongruous with such a physically powerful event. For example, although we do not know the impact of Hurricane Hugo on marsh surface elevation change throughout the entire coastline it affected, that storm had no long-term impact on salt marsh integrity at North Inlet in South Carolina (Gardner and others, 1991, 1992). Similarly, Rachlin and others (2017) report that species composition of vascular flora of salt marshes in New Jersey, New York, and Connecticut showed a high degree of stability (in other words, little change) following Hurricane Sandy. Longenecker and others (2018) report that vegetation cover and composition were similar before and after Hurricane Sandy in tidal marsh at Edwin B. Forsythe NWR in New Jersey, which is located at the point of landfall. In addition, Wang and others (2017) report a very complex pattern of accretion and erosion of marsh surfaces for salt marshes across Jamaica Bay, but eroded marsh surfaces recovered from the sediment loss after 1 year. Quirk (2016) hypothesized that Hurricane Sandy impacts on marsh surface accretion and elevation change will have little influence on longer-term elevation trends as well. Given the degree of spatial variation we found in Hurricane Sandy surge effects on marsh elevation change, the implications for marsh resilience to future storms also will vary spatially across the northeastern United States.

Our analyses provide inferences for storm impacts in the short-term (1-year poststorm). Namely, those stations located left of landfall, compared to those on the right, experienced a greater deviation from expected elevation change, and the deviation was more likely to be positive (elevation gain). Stations to the right of landfall experienced smaller maximum deviations from expected, and the deviations were more likely to be negative (elevation loss). Although long-term inferences $(>1$ year poststorm) cannot be drawn from our analyses, it is clear that the more prevalent gain in elevation in the marshes located left of storm landfall more likely resulted in gains in elevation capital (marsh elevation in relation to mean sea level; Reed, 2002; Cahoon and Guntenspergen, 2010) for those marshes. In contrast, the predominance of elevation loss in marshes to the right of landfall in the barrier island systems of northern New Jersey, New York, and Connecticut likely indicates those marshes lost elevation capital. Another potential factor contributing to elevation loss in the northern marshes to the right of landfall is that they are all built on underlying coarse-grained parent materials deposited during and immediately after the last glaciation. This has implications for sediment transport and trapping, with northern marshes often considered sediment starved and more dependent on organic matter accumulation, which ultimately impacts 
long-term marsh stability (Stevenson and others, 1988). Hurricane Sandy came ashore just south of the glacial deposit line, which adds another confounding factor in understanding the geomorphic setting along this coastline.

Future coastal flood risk for the east coast of the United States will be strongly influenced by sea-level rise and changes in the frequency and intensity of tropical cyclones (Tebaldi and others, 2012; Woodruff and others, 2013; Little and others, 2015). The return period for Hurricane Sandy's flood height is predicted to decrease during the next century by a factor of as much as 17-fold, owing to both sea-level rise and changes in storm climatology (Lin and others, 2016). The frequency of tropical cyclones is projected to decrease, although the frequency of more intense storms (category 4 and 5) is projected to increase, as is overall tropical cyclone intensity (Knutson and others, 2010; Bender and others, 2010; Peduzzi and others, 2012). For the northeastern U.S. coast (Virginia and northward), relative sea-level rise is projected to be greater than the global average for most future Global Mean Sea Level rise scenarios (for example, 0.3 to $0.5 \mathrm{~m}$ or more by the year 2100 under the Intermediate Scenario [Sweet and others, 2017]), and the mid-Atlantic coast of the United States is considered a hotspot of accelerated sea-level rise (Sallenger and others, 2012). Furthermore, acceleration in flooding, including minor flooding, is predicted to occur for the northeast region (Ezer and Atkinson, 2014), although the existence of coastal wetlands is known to reduce flood damage to human infrastructure on the coast (Narayan and others, 2017). Thus, gains in marsh elevation capital are needed to offset the projected increases in sea level and coastal flooding frequency (Cahoon, 2015), and to sustain existing marshes. Notably, as a result of Hurricane Sandy, more marshes in the Delaware Bay and Chesapeake Bay region gained short-term resilience than marshes in the New Jersey to Connecticut region. Yet, each future major storm to make landfall in the northeastern United States will have its own unique characteristics and storm surge impacts on coastal marsh elevation that will have a cumulative effect on future marsh elevation capital and resilience. The impact of each high-magnitude, low frequency storm event (in other words, hurricanes) will be additive to the impacts of the low-magnitude, high-frequency storm events (in other words, northeaster storms) that typically occur in the northeast region of the United States each year and can generate substantial storm surges during the winter and spring (Davis and Dolan, 1993; Booth and others, 2016).

\section{Factors to Consider in Development of a Strategic Monitoring Framework}

Objective 4 of this project is to develop a framework for a strategic monitoring network of SET-MH (from here on SET) stations in the northeastern United States to improve assessments of climate change impacts and related phenomena on coastal wetlands. The 965 eligible SET stations located in the northeastern United States (fig. 3), including both geomorphic settings of estuarine marsh and back-barrier lagoonal marsh, are classified as estuarine emergent marsh (NWI classification: E2EM) habitat. We provide information on the spatial distribution of SET stations and compare this with the amount and distribution of estuarine emergent marsh across the region (fig. 16). We also incorporated two risk factors into this analysis: hurricane return interval and storm surge footprint. These analyses will highlight geographical areas that are under-represented by SET stations and can be used to guide future installation and improve our assessment of coastal marsh resilience to the impact of climate change and stormrelated phenomena on coastal wetlands.

\section{Methods}

\section{Spatial Analysis}

The number of hexagons (each 4,000 ha or $40 \mathrm{~km}^{2}$ in area; Weist and others, 2016), amount of marsh area, number of marsh patches, dominant geomorphic settings, and number of SET stations per predefined subregion were determined. The spatial distribution and density of SET stations in the study area was summarized in ArcMap 10.1 to show the number of stations per subregion, number of marsh patches with stations present, number of stations per hexagon, and the number of stations with federally owned data, indicating there is a long-term commitment to data collection. The spatial distribution of estuarine emergent marsh was determined for each subregion as the total marsh area, number of marsh patches and broad geomorphic settings of marsh patches, total marsh area per hexagon, and the presence of publicly owned estuarine emergent marsh within each hexagon, indicating potential locations for future SET station installations. From these analyses we calculated the percent of hexagons containing SET stations, the density of stations per marsh area for each subregion expressed as the number of stations per 1,000 ha of marsh area, the percentage of marsh patches per subregion containing stations, and the broad geomorphic settings of station locations. 


\section{Incorporating Risk-Data Sources and Application}

There are a multitude of additional factors that could be considered when identifying spatial gaps in an opportunistic assemblage of stations. We identified two additional risk factors with data available for the entire study area: hurricane return interval and storm surge footprint. The return interval of hurricanes (100 years/number of hurricane strikes) was calculated for the coastal counties on the basis of data from the National Hurricane Center (NHC), which maintains a list of all direct and indirect strikes from all hurricane categories from 1900-2009, and was last updated in February 2010 (National Oceanic and Atmospheric Administration, 2010). For this project, direct and indirect strikes of all hurricane categories were included in the number of hurricane strikes over the length of record.
The potential storm surge footprint was acquired from the Sea, Lake, and Overland Surges from a Hurricane (SLOSH) model (Forbes and others, 2014) that is used by the National Weather Service and NHC to compute storm surge and create management and planning products based on hypothetical hurricane tracks. We used the potential storm surge footprints for the maximum of maximums (MOM) for hurricane categories $1-5$, which represent the worst case scenario based on model results from more than 10,000 simulated storms (Federal Emergency Management Agency, 2015b). See also Longenecker (2011).

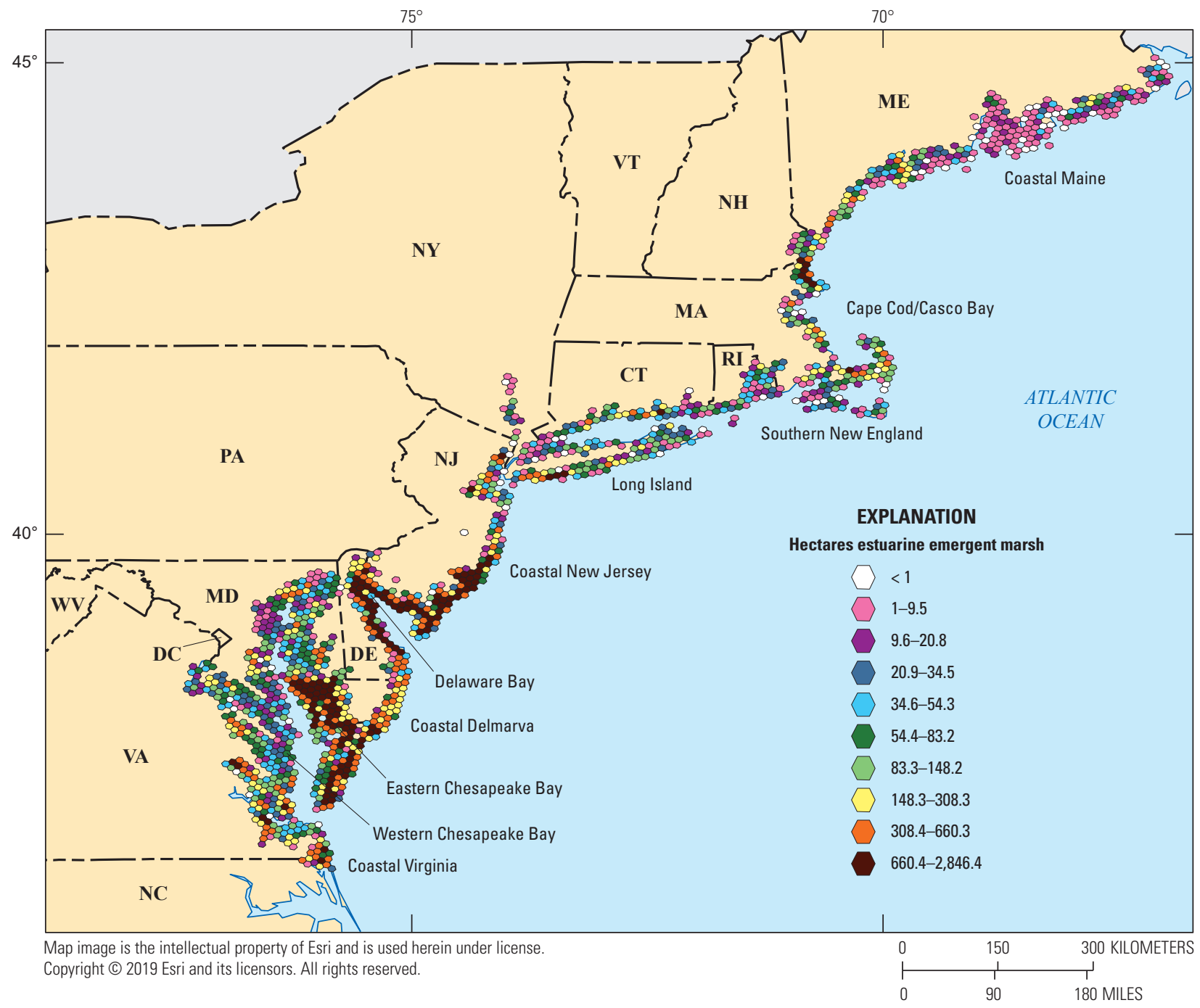

Figure 16. Study region between Maine and Virginia (inclusive) indicating area of estuarine emergent marsh per hexagon (40 square kilometers or 4,000 hectares). Note the hexagon grid is restricted to areas where estuarine emergent marsh is present in the National Wetlands Inventory acquired in 2010. 


\section{Results}

\section{Spatial Distribution of SET-MH Stations}

Spatial distribution of SET stations across the Atlantic coast from Virginia to Maine can be evaluated for the entire region or by subregion. SET stations are not evenly distributed across the region, as installations were based on agency and project priorities. We then calculated the percent of hexagons in each subregion that contain SET stations (table 13). With this approach, five of the subregions (Cape Cod-Casco Bay, Long Island, coastal New Jersey, Delaware Bay, and coastal Delmarva) are fairly evenly represented with 18-22 percent of hexagons containing some SET stations. However, southern New England and coastal Virginia have few hexagons with stations (approximately 9.5 percent), and coastal Maine, as well as both western and eastern Chesapeake Bay, are much less represented with less than 8 percent of the hexagons in those regions containing stations. SET stations are also unevenly distributed within each subregion (fig. 17). For example, most of the SET stations in the coastal Maine subregion are in the northern portion (fig. 2).

Subregions are not equivalent with respect to marsh area, marsh patch size, and geomorphic settings. Therefore, we summarized the number and size of marsh patches per subregion and the density of SET stations relative to existing estuarine emergent marsh (table 14). Two of the four subregions with the greatest number of SET stations (coastal New
Jersey $=141$ and eastern Chesapeake Bay $=102$ ) have large areas of marsh ( $>50,000 \mathrm{ha})$ and consequently low densities of stations per marsh area (2.8 and 1.51 stations per 1,000 ha of marsh, respectively; table 14). Coastal Maine, eastern Chesapeake Bay, and western Chesapeake Bay are underrepresented by percent of marsh patches with SET stations (less than 1 percent of marsh patches containing stations), and the density of SET stations was low in the southern portion of the region (fewer than 3 stations per 1,000 ha of marsh) and in coastal Maine (4.8 stations per 1,000 ha of marsh) compared to the midregion from Long Island to Cape Cod/Casco Bay (>9 stations per 1,000 ha of marsh; table 14).

The percent of hexagons with SETs per subregion was not evenly distributed $\left(\chi^{2}=42.5, \mathrm{df}=9, P<0.001\right)$, and the density of SETs (number of stations per 1,000 ha estuarine emergent marsh) was strongly clustered (Global Moran's $\mathrm{I}=0.157, P<0.001$ ), confirming that SET stations are not evenly distributed.

Within each subregion, SET stations were generally clustered on the basis of Global Moran's I, a measure of spatial autocorrelation, calculated for number of stations per 1,000 ha of estuarine emergent marsh in each hexagon (table 13). Southern New England and coastal New Jersey subregions were exceptions, in that distribution of SET station density was not significantly different from random (Global Moran's I $P$-values $>0.1)$. Each subregion also had at least one pair of adjacent hexagons that both contained some SET stations. Therefore, the overall minimum distance between hexagons with SET stations was $0 \mathrm{~km}$. However, the mean minimum distance (or the mean distance to the nearest hexagon with

Table 13. Summary of the spatial distribution of surface elevation table-marker horizon (SET-MH) stations, hexagons (with estuarine emergent marsh [E2EM]), hexagons (with E2EM marsh) with SET-MH stations, mean minimum distance between hexagons with SETs, and Global Moran's I (measure of clustering) across 10 subregions between Maine and Virginia (inclusive).

[ $\mathrm{km}^{2}$, square kilometer; $\mathrm{m}$, meter; ha, hectare; $<$, less than]

\begin{tabular}{|c|c|c|c|c|c|c|c|}
\hline Subregion & $\begin{array}{l}\text { Number of } \\
\text { SET-MH } \\
\text { stations }\end{array}$ & $\begin{array}{l}\text { Percent of } \\
\text { SET-MH } \\
\text { stations }\end{array}$ & $\begin{array}{c}\text { Total number } \\
\text { of hexagons } \\
\left(40 \mathrm{~km}^{2}\right)\end{array}$ & $\begin{array}{l}\text { Number of } \\
\text { hexagons } \\
\text { with SETs }\end{array}$ & $\begin{array}{l}\text { Percent of } \\
\text { hexagons } \\
\text { with SETs }\end{array}$ & $\begin{array}{c}\text { Mean minimum } \\
\text { distance }(\mathrm{m}) \\
\text { between hexagons } \\
\text { with SETs }\end{array}$ & $\begin{array}{c}\text { Global Moran's I } \\
\text { (for number of } \\
\text { SETs } / 1,000 \text { ha } \\
\text { marsh) }\end{array}$ \\
\hline Cape Cod, Casco Bay & 189 & 19.6 & 113 & 25 & 22.1 & 271 & $0.215 * * *$ \\
\hline Southern New England & 124 & 12.8 & 180 & 17 & 9.4 & 6,898 & 0.983 \\
\hline Coastal New Jersey & 141 & 14.6 & 109 & 24 & 22.0 & 1,533 & 0.087 \\
\hline Delaware Bay & 88 & 9.1 & 88 & 19 & 21.6 & 715 & $0.229 * * *$ \\
\hline Coastal Delmarva & 90 & 9.3 & 93 & 17 & 18.3 & 1,323 & $0.202 * *$ \\
\hline Eastern Chesapeake Bay & 120 & 12.4 & 212 & 16 & 7.1 & 3,410 & $0.149 * * *$ \\
\hline
\end{tabular}

*Significantly different from random (clustered) with $\mathrm{P}$ value $<0.1$.

**Significantly different from random (clustered) with $\mathrm{P}$ value $<0.01$.

$* * *$ Significantly different from random (clustered) with $\mathrm{P}$ value $<0.001$. 
A

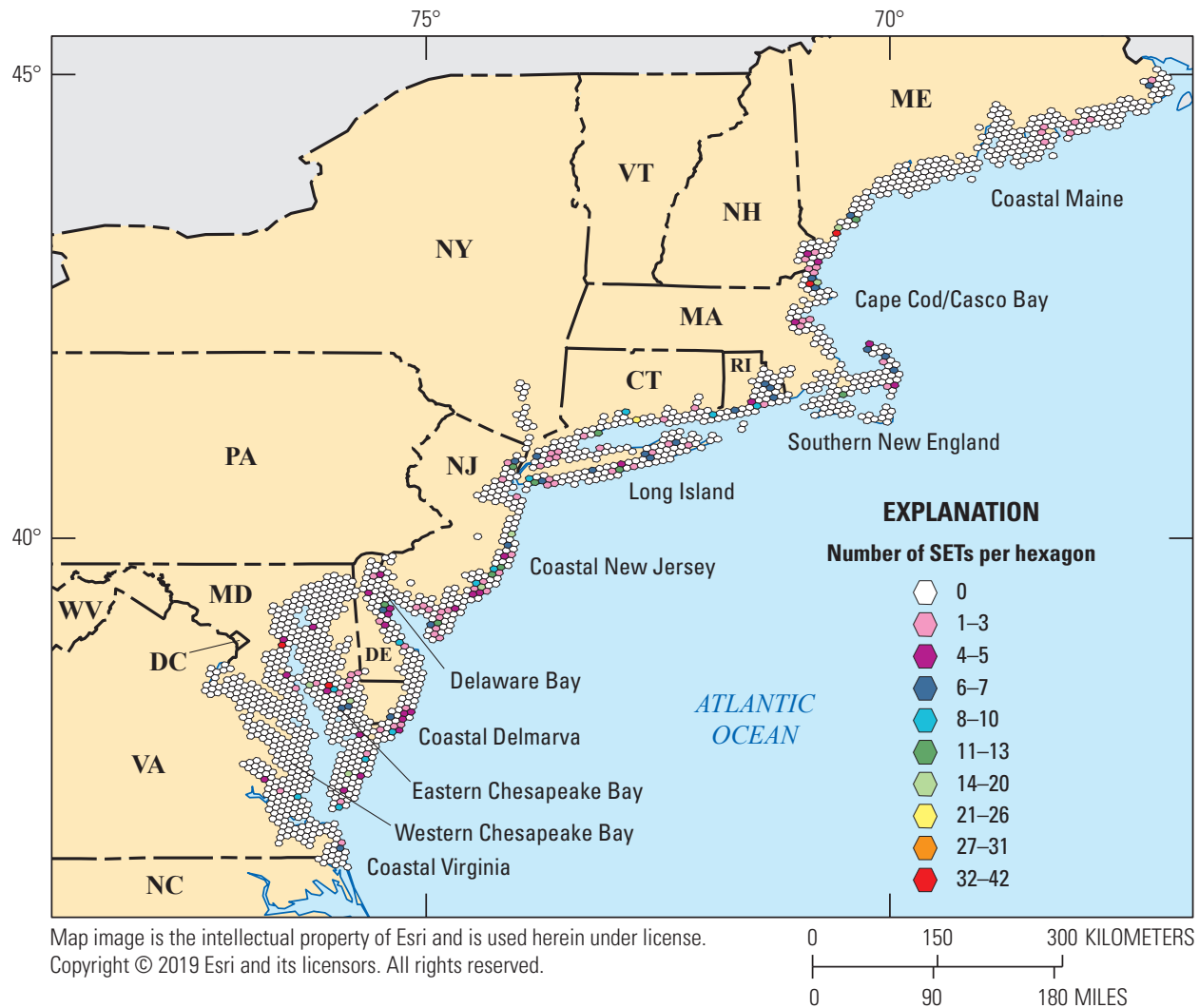

$B$

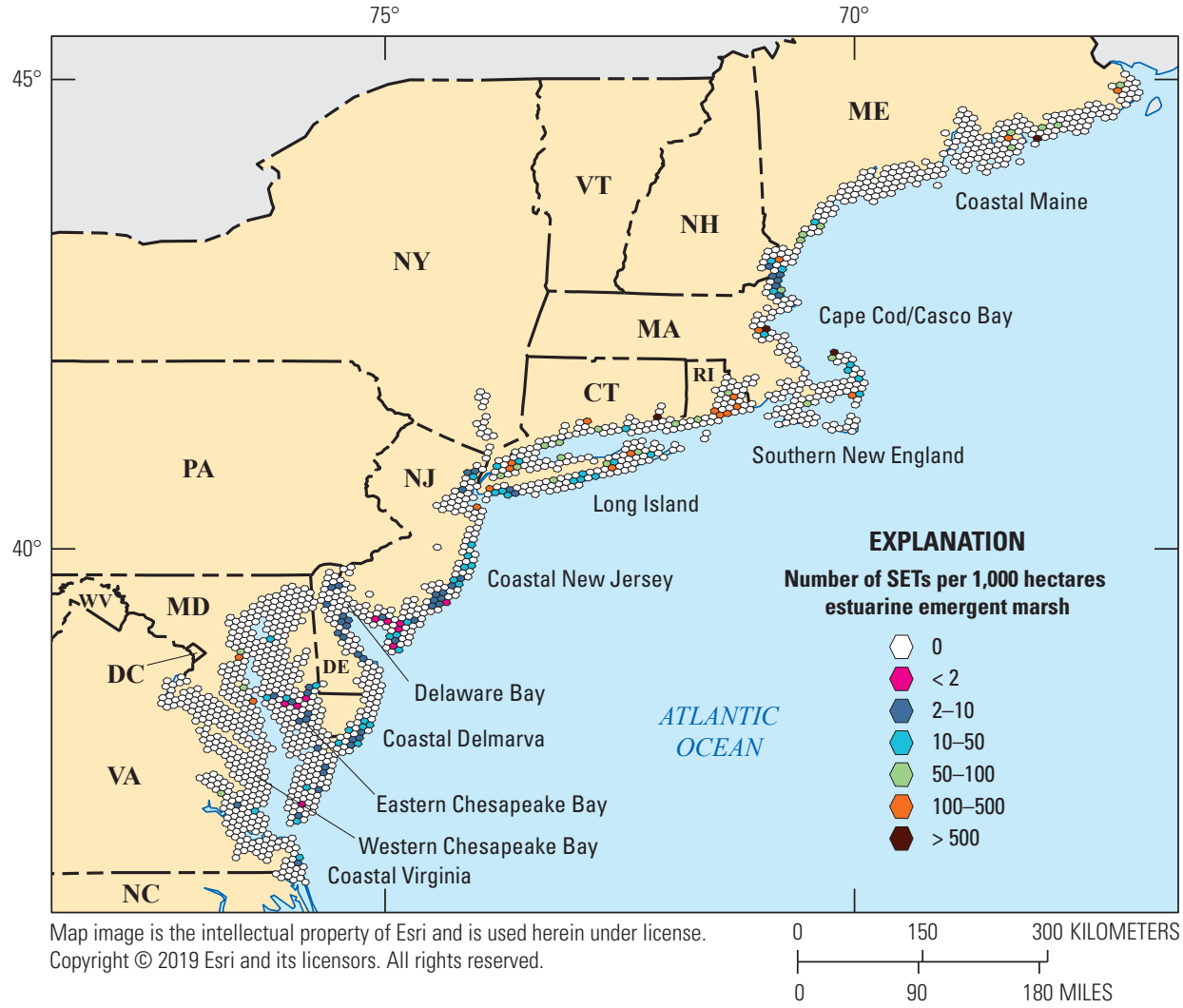

Figure 17. Study region between Maine and Virginia (inclusive) indicating $A$, number of surface elevation table-marker horizon (SET-MH) stations per hexagon (40 square kilometers or 4,000 hectares [ha]), and $B$, number of SETs per 1,000 ha estuarine emergent marsh (E2EM) in each hexagon. Note that the hexagon grid is restricted to areas where E2EM is present in the National Wetlands Inventory acquired in 2010. 
SET stations) ranged from $0 \mathrm{~km}$ in coastal Virginia (where there are only two hexagons with SET stations) to $7.4 \mathrm{~km}$ in western Chesapeake Bay (table 13). The maximum distance to the nearest hexagon with SET stations ranged from 0 (coastal Virginia) to $34 \mathrm{~km}$ (southern New England).

\section{SET Station Distribution Within a Subregion}

Within a subregion, additional detail can be incorporated to identify gaps in SET station coverage of geomorphic settings present. For example, we quantified the broad geomorphic settings present in the marsh patches of each subregion and then compared the broad geomorphic settings of the existing SET stations (table 15, figs. 18 and 19). This comparison is not relevant for subregions where there is only one broad geomorphic setting present, such as eastern and western Chesapeake Bay, and Delaware Bay. For several subregions, however, this comparison highlights existing gaps. In coastal Virginia, all stations are located in back-barrier lagoon settings, even though the percentage of total marsh area in this geomorphic setting is only 29.1 percent (table 15). In the Cape Cod/Casco Bay subregion, most stations (by count, number of marsh patches, and number of hexagons) are located in backbarrier lagoon settings, even though there is a mix of estuarine and back-barrier lagoon marsh patches in the subregion (26.2 percent and 73.8 percent of marsh area, respectively; table 15). The inverse is true in southern New England, where most stations (by count, number of marsh patches, and number of hexagons) are located in estuarine settings, even though there is a fairly even mix of estuarine and back-barrier lagoon marsh patches in the subregion (37.7 percent and 61.8 percent of marsh area, respectively; table 15).
At the subregion level, the amount of marsh area (fig. 16) can be used to identify areas/hexagons in which multiple SET stations would be recommended (a greater number of replicate stations for those hexagons with more marsh area). At a local level (within a hexagon), there are other details to be considered, including marsh patch ownership (for example, Federal lands, fig. 20A) and availability of observers. Additionally, the presence of publicly owned marsh (fig. 20B) could be used within an area identified as a spatial gap to highlight candidate hexagons for future installations. Additional information about SET station distribution within a marsh or study area is presented in the SET-MH protocol manual (Lynch and others, 2015).

\section{Incorporating Risk}

This report includes spatial representation of two risk factors associated with hurricanes that could be considered when identifying spatial gaps in an opportunistic network: the return interval of hurricanes by county (fig. 21) and the potential storm surge footprint (fig. 22-25). These risk factors are shown in relation to the hexagon sampling grid with current SET locations highlighted. Note that the color coding of the storm strength categories is cumulative, where red indicates flooded by hurricanes of category 1 and above, orange by category 2 and above, yellow by category 3 and above, and green by category 4 and above. FEMA SLOSH modeling for category 5 hurricanes was not completed for areas north of North Carolina, and thus this category was not included in the analyses. Note that some hexagons appear to have no data for the hurricane return period and storm surge footprint. This is due to the fact that some marsh areas (and therefore hexagons)

Table 14. Summary of the spatial distribution of estuarine emergent marsh patches (E2EM) and surface elevation table-marker horizon (SET-MH) stations within marsh patches among 10 subregions between Maine and Virginia (inclusive).

[ha, hectare]

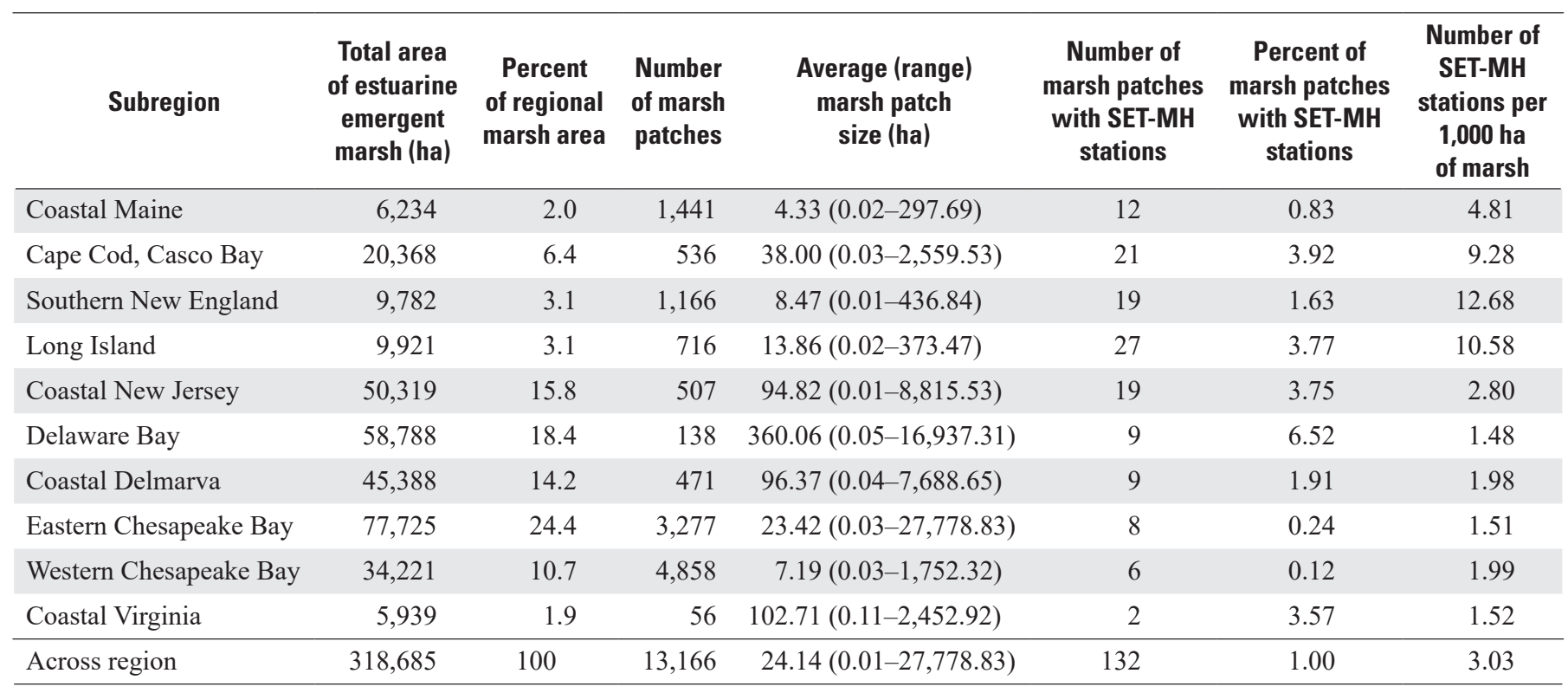


are not included in the terrestrial boundaries of counties and modeling efforts. It can be assumed that hexagons to the open water side of counties have the same hurricane return interval as the adjacent county and that these hexagons are flooded by all storm surges.

\section{Risk of Hurricane Strikes and Storm Surge by Subregion}

The subregion with the highest hurricane return interval ( $<10$ years) is coastal Virginia, which represents a small portion of the entire study area (fig. 21). However, this subregion has among the lowest number of SET stations per 1,000 ha of marsh (1.52) in the entire study area (table 14). A much greater portion of the study area, in particular the central portion, experiences a 10-30 year return interval, including parts of western Chesapeake Bay, coastal Delmarva, Delaware Bay, coastal New Jersey, Long Island, southern New England, Cape Cod/Casco Bay, and coastal Maine (fig. 21). The Long Island, southern New England, Cape Cod/Casco Bay and coastal Maine subregions have the highest number of SET stations per 1,000 ha of marsh in the study area (table 14). Yet the percent of marsh patches with SET stations is low in many of these subregions, especially western Chesapeake Bay, coastal Delmarva, southern New England, and coastal Maine (table 14), such that many areas of these subregions do not have any SET stations. A smaller portion of the study area that includes western Chesapeake Bay, coastal Delmarva, and coastal New Jersey experiences a 30-50 year return interval, and there are only about 2 SET stations per 1,000 ha of marsh in these subregions. The longest hurricane return intervals (50-100 years and $>100$ years) occur primarily in the eastern Chesapeake Bay, Cape Cod/Casco Bay, and coastal Maine subregions.

The predicted worst-case scenario storm surge footprints acquired from the SLOSH model for the MOM for storm categories $1-5$ are presented in figure 22 for the entire study area and for the northern, central, and southern portions of the study area in figures 23-25. Storm surge footprints are most prevalent in the southern portion of the study area from coastal New Jersey to coastal Virginia (figs. 23-25), where all subregions are broadly impacted except for the western Chesapeake Bay. For the southern portion of the study area there are less than 2 SET stations per 1,000 ha of marsh, except for coastal New Jersey where there are 2.80 SET stations per 1,000 ha of marsh. A higher resolution view of storm surge footprints for each subregion is presented in figures 26-32. In the coastal Maine subregion, SET stations are not located within the storm surge footprints. In the remaining subregions, there is much stronger overlap between SET station locations and storm surge footprints, although there are no SET stations in some prominent storm surge footprints.

\section{Discussion}

During the past two decades, more than 1,100 SET stations have been installed in coastal marshes in the northeastern United States in 96 unique geographic settings. These stations were installed separately and independently by academic researchers; local, state, and Federal government agencies (for example, USGS, NOAA, National Park Service, U.S. Fish and Wildlife Service), and non-government organizations for the

Table 15. Summary of the spatial distribution of surface elevation table-marker horizon (SET-MH) stations, estuarine emergent marsh patches (E2EM), and geomorphic settings among 10 subregions between Maine and Virginia (inclusive).

\begin{tabular}{|c|c|c|c|c|c|c|c|c|}
\hline \multirow[t]{2}{*}{ Subregion } & \multicolumn{2}{|c|}{$\begin{array}{l}\text { Broad geomorphic } \\
\text { settings of all } \\
\text { marsh patches; } \\
\text { percent by count } \\
\text { and (area) }\end{array}$} & \multicolumn{2}{|c|}{$\begin{array}{l}\text { Broad geomorphic } \\
\text { settings of SETs; } \\
\text { percent by count }\end{array}$} & \multicolumn{2}{|c|}{$\begin{array}{l}\text { Broad geomorphic } \\
\text { settings of SETs; } \\
\text { percent of marsh } \\
\text { patches with SETs }\end{array}$} & \multicolumn{2}{|c|}{$\begin{array}{l}\text { Broad geomorphic } \\
\text { settings of SETs; } \\
\text { percent of hexagons } \\
\text { with SETs }\end{array}$} \\
\hline & Estuarine & $\begin{array}{l}\text { Back-barrier } \\
\text { lagoon }\end{array}$ & Estuarine & $\begin{array}{l}\text { Back-barrier } \\
\text { lagoon }\end{array}$ & Estuarine & $\begin{array}{l}\text { Back-barrier } \\
\text { lagoon }\end{array}$ & Estuarine & $\begin{array}{c}\text { Back-barrier } \\
\text { lagoon }\end{array}$ \\
\hline Cape Cod, Casco Bay & $65.3(26.2)$ & $33.6(73.8)$ & 12.2 & 86.2 & 23.8 & 76.2 & 24.0 & 76.0 \\
\hline Southern New England & $52.0(37.7)$ & $47.3(61.8)$ & 62.9 & 29.8 & 63.2 & 31.6 & 70.6 & 29.4 \\
\hline Long Island & $5.5(4.8)$ & $94.4(95.2)$ & 14.3 & 85.7 & 14.8 & 85.2 & 17.4 & 95.7 \\
\hline Coastal New Jersey & $32.7(9.9)$ & $67.3(90.1)$ & 17.0 & 83.0 & 21.1 & 78.9 & 16.7 & 83.3 \\
\hline Western Chesapeake Bay & $100(100)$ & $0(0)$ & 100 & 0 & 100 & 0 & 100 & 0 \\
\hline Coastal Virginia & $28.6(70.9)$ & $71.4(29.1)$ & 0 & 100 & 0 & 100 & 0 & 100 \\
\hline Across region & $82.1(61.4)$ & $17.7(38.6)$ & 46.3 & 52.4 & 45.9 & 53.4 & 48.4 & 53.8 \\
\hline
\end{tabular}


purpose of investigating and monitoring elevation dynamics in coastal wetlands. The SET stations are located in wetlands that are best suited to address specific research questions or monitor the habitat sustainability of important biological resources at a specific wetland. Thus, this existing network of stations represents an opportunistic collection of sampling locations that are not a strategically deployed collection of stations designed to evaluate wetland elevation dynamics on broader regional scales or across a suite of geomorphic settings and environmental stressors. One purpose of this report was to provide a framework that can be used to develop a strategically designed SET sampling network for the northeastern region of the United States. The intended audience consists of policy makers, government resource management agencies, and SET practitioners. The goal is for this information to be used in decision-making regarding where new SET stations are installed in the northeastern United States, filling in gaps in the existing opportunistic network when possible, to better address priority concerns for the region.

To this end, the report provides examples of how a regional inventory of SET station metadata can be used to identify limitations in an opportunistic network, which can inform decisions on future installations. For example, our evaluation of the northeastern region assemblage of stations reveals that the general geographic coverage of SET stations is limited, given the low percentage of marsh patches with stations, the low density of stations (number per 1,000 ha of marsh), and the clumped distribution of stations in 8 of the 10 subregions. Furthermore, each rod SET station covers only $\sim 1.37$ square meters of marsh surface area, leading to a recent

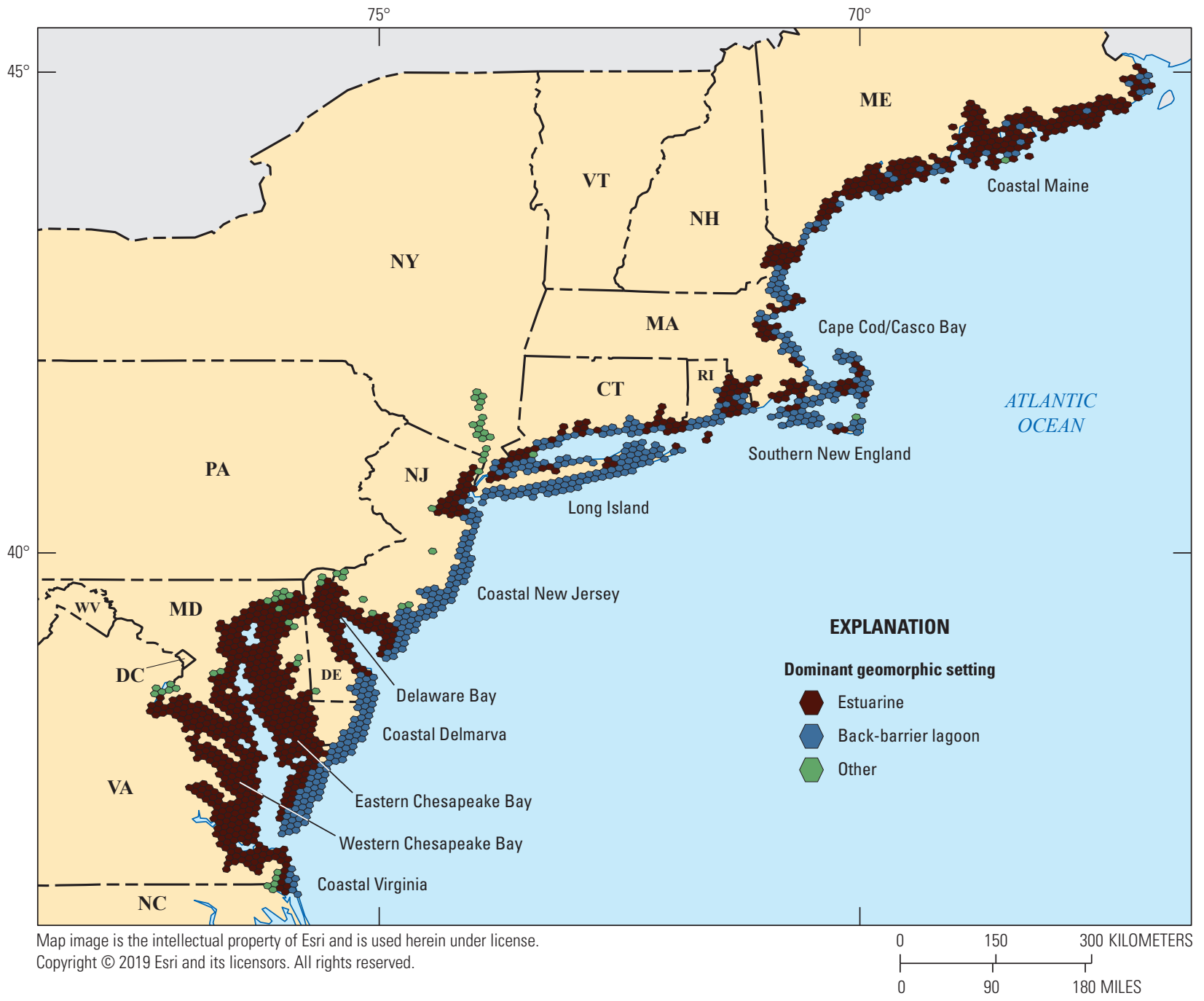

Figure 18. Dominant broad geomorphic setting of marsh patches (estuarine emergent marsh; E2EM) in each hexagon (40 square kilometers) across the study region (Virginia to Maine, inclusive). Note that the hexagon grid is restricted to areas where E2EM is present in the National Wetlands Inventory acquired in 2010. Estuarine category includes estuarine embayment and estuarine brackish marsh. Back-barrier lagoon category includes back-barrier lagoon marsh and estuarine embayment systems within back-barrier lagoons. Other category includes open coast and tidal fresh marsh. 
$\boldsymbol{A}$

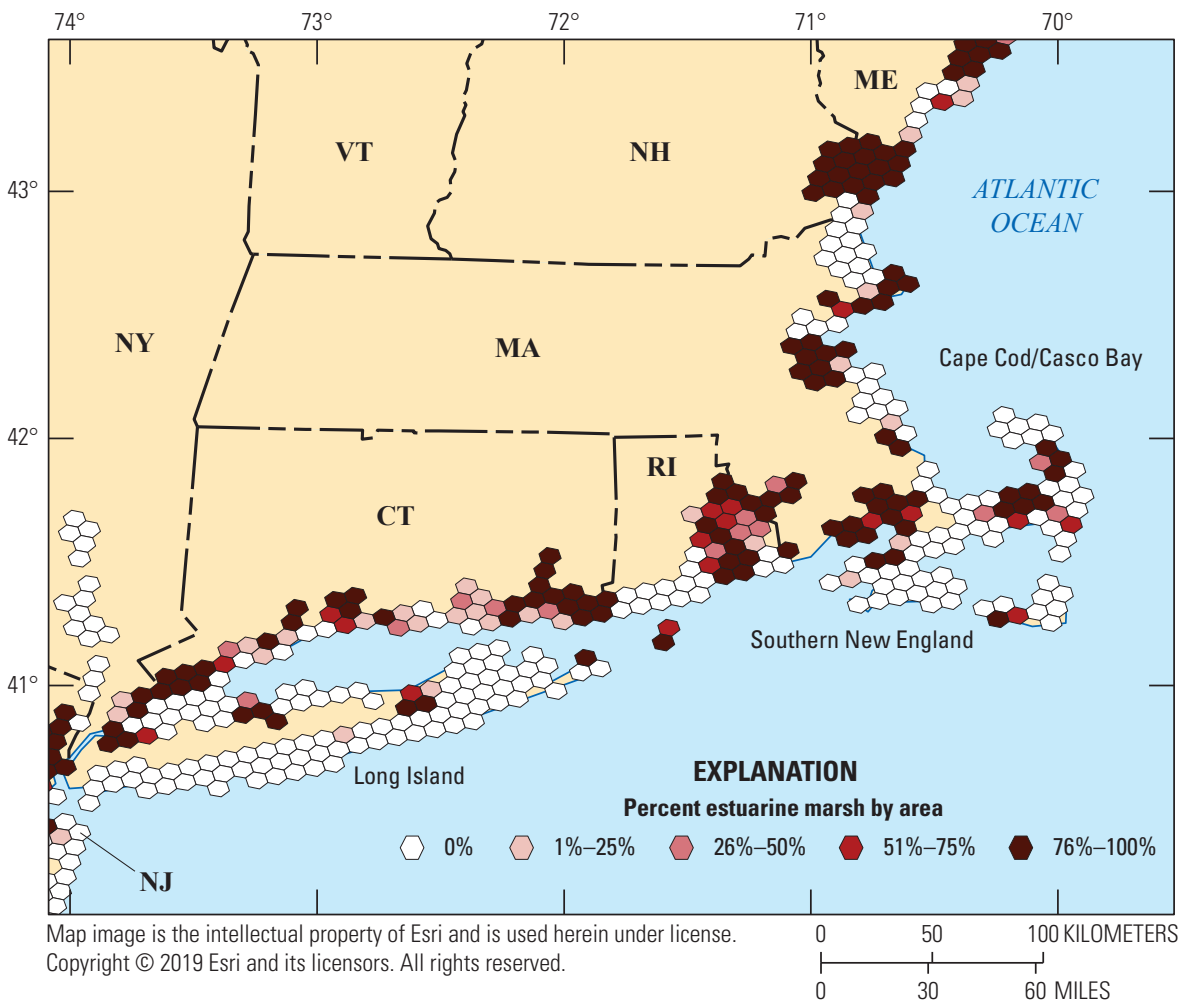

$B$

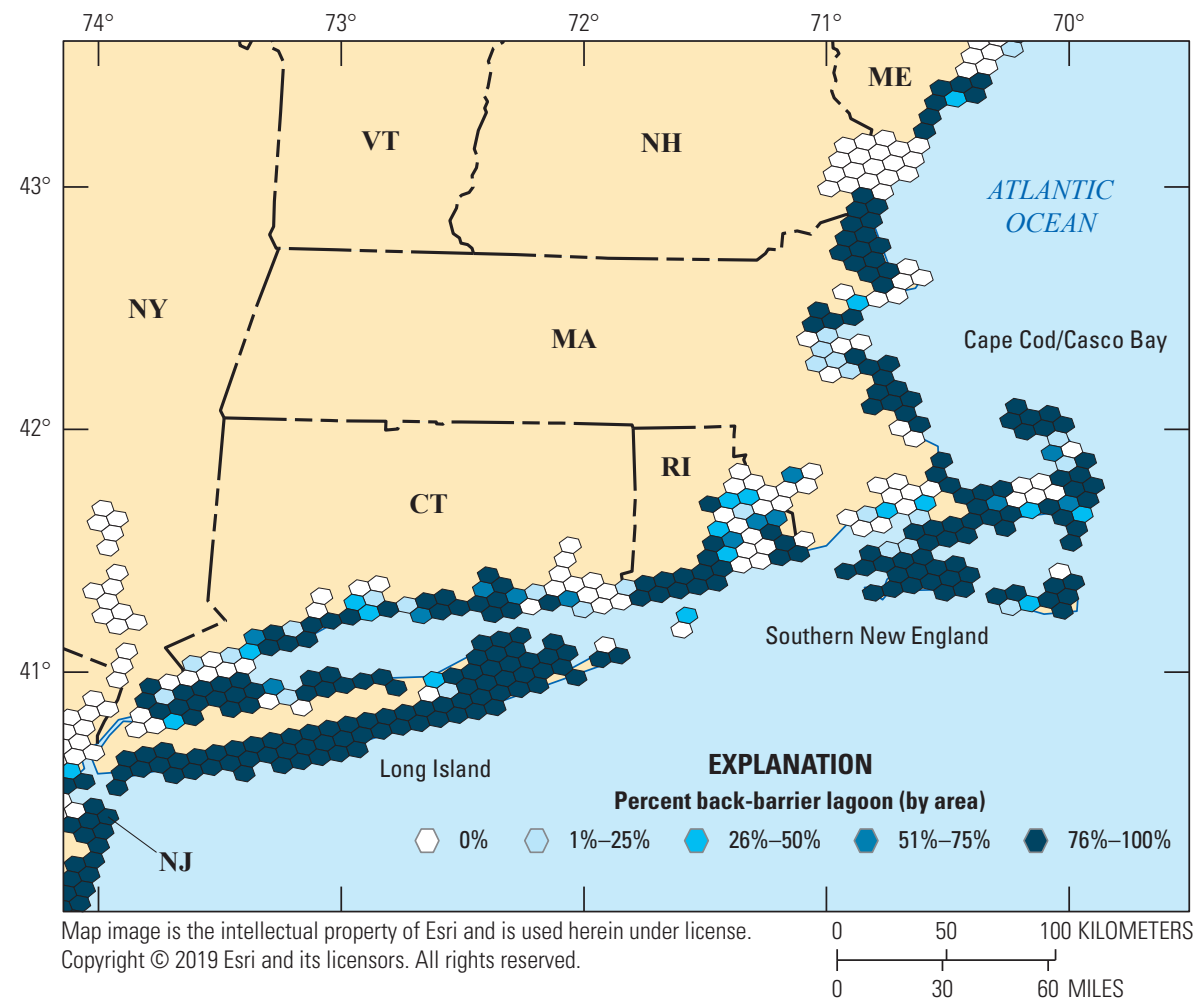

Figure 19. Percent of estuarine emergent marsh patch (E2EM) area by broad geomorphic settings in each hexagon (40 square kilometers) across several subregions with mixed geomorphic settings (Long Island, southern New England, and Cape Cod/Casco Bay), with $A$, percent estuarine marsh, and $B$, percent back-barrier lagoon. Note that the hexagon grid is restricted to areas where E2EM is present in the National Wetlands Inventory acquired in 2010. Estuarine category includes estuarine embayment and estuarine brackish marsh. Back-barrier lagoon category includes back-barrier lagoon marsh and estuarine embayment systems within back-barrier lagoons. 
$\boldsymbol{A}$

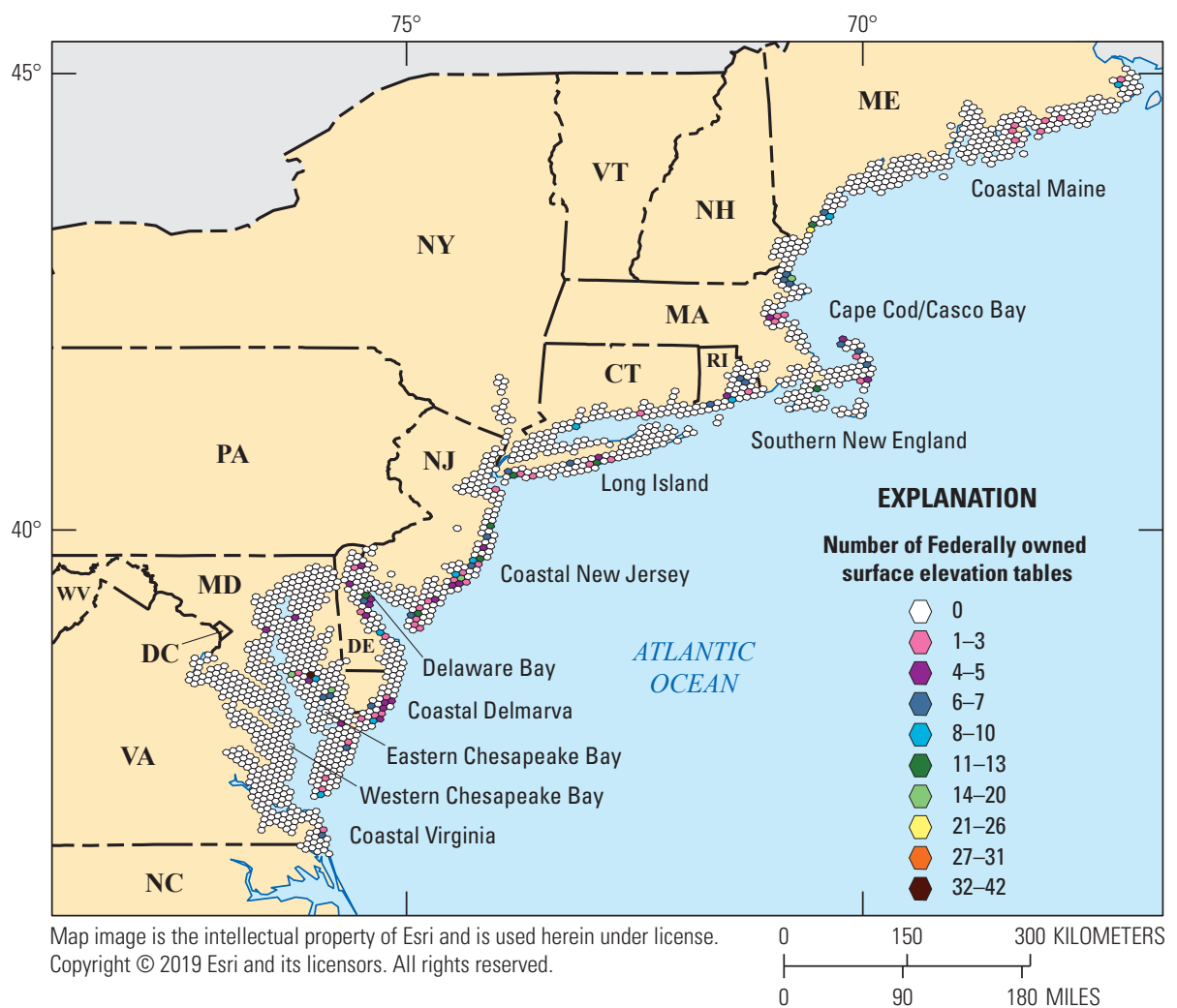

$B$

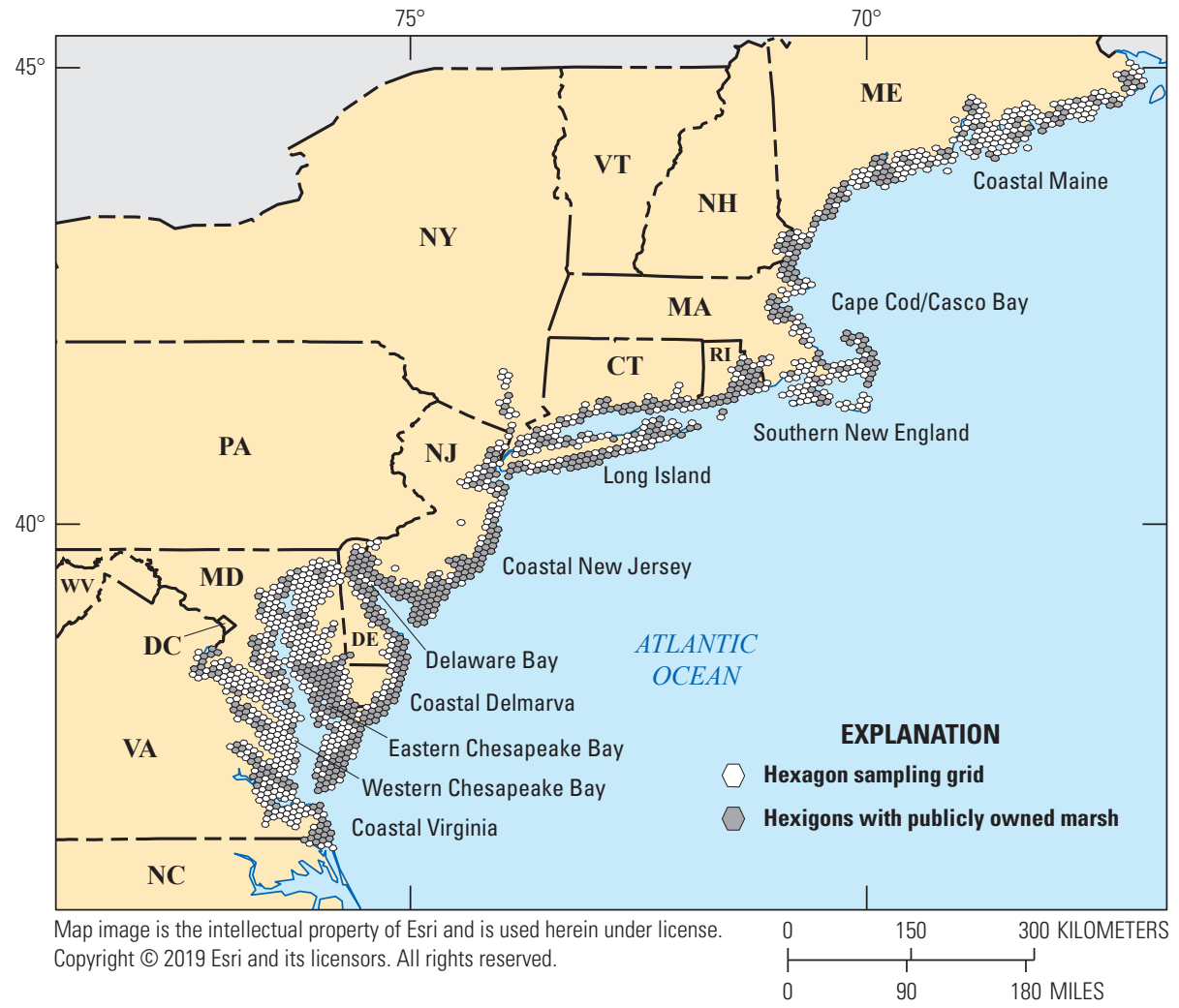

Figure 20. Study region between Maine and Virginia (inclusive) indicating $A$, the number of surface elevation table-marker horizon (SET-MH) stations owned by Federal agencies per hexagon (40 square kilometers), 664 SETs in 107 hexagons; and $B$, hexagons with publicly owned marsh (by states, National Park Service, or U.S. Fish and Wildlife Service). Note that the hexagon grid is restricted to areas where estuarine emergent marsh is present in the National Wetlands Inventory acquired in 2010. 
innovation to expand wetland elevation measures across 1 ha of marsh surface from an SET station using a level (Cain and Hensel, 2017). In addition, coverage of the two dominant geomorphic settings in a subregion is often skewed to one of the two settings, and the distribution of stations in wetlands with a high probability of hurricane strikes and storm surge impacts is often limited and uneven. These analyses can be used to address priority regional concerns such as a broader geographical understanding of the vulnerability of coastal marshes in the region to relative sea-level rise, including a comparison of geomorphic settings, and the impacts of storms on wetland resilience. Such a strategic network can provide data to managers and policymakers that better inform the development of management and adaptation plans for coastal resources in the region.

The priority concerns for the northeastern region will have to be developed by the target audience of this report, namely, the regional policymakers and resource managers charged with maintaining these critical biological resources. During planning for a strategic distribution of SET stations, there are other issues to be addressed before the plan can be implemented, specifically, financial and infrastructural support. Development of a regional monitoring network requires not only financial investment in the SET-MH equipment but also in the personnel to install the stations and collect and manage the data over the long-term (Webb and others, 2013). This typically requires institutional commitment and support; see for an example the Louisiana Coast-wide Reference Monitoring System (https://www.lacoast.gov/crms/Home.aspx). At the local or subregion scale, SET stations can be strategically installed in locations and settings gradually over time, and for a lower initial investment, to fill in the existing gaps in the opportunistic network.

Finally, the analyses of regional storm impacts were limited by the exclusion of a majority of stations where SET data did not meet the criteria needed for the analyses. There

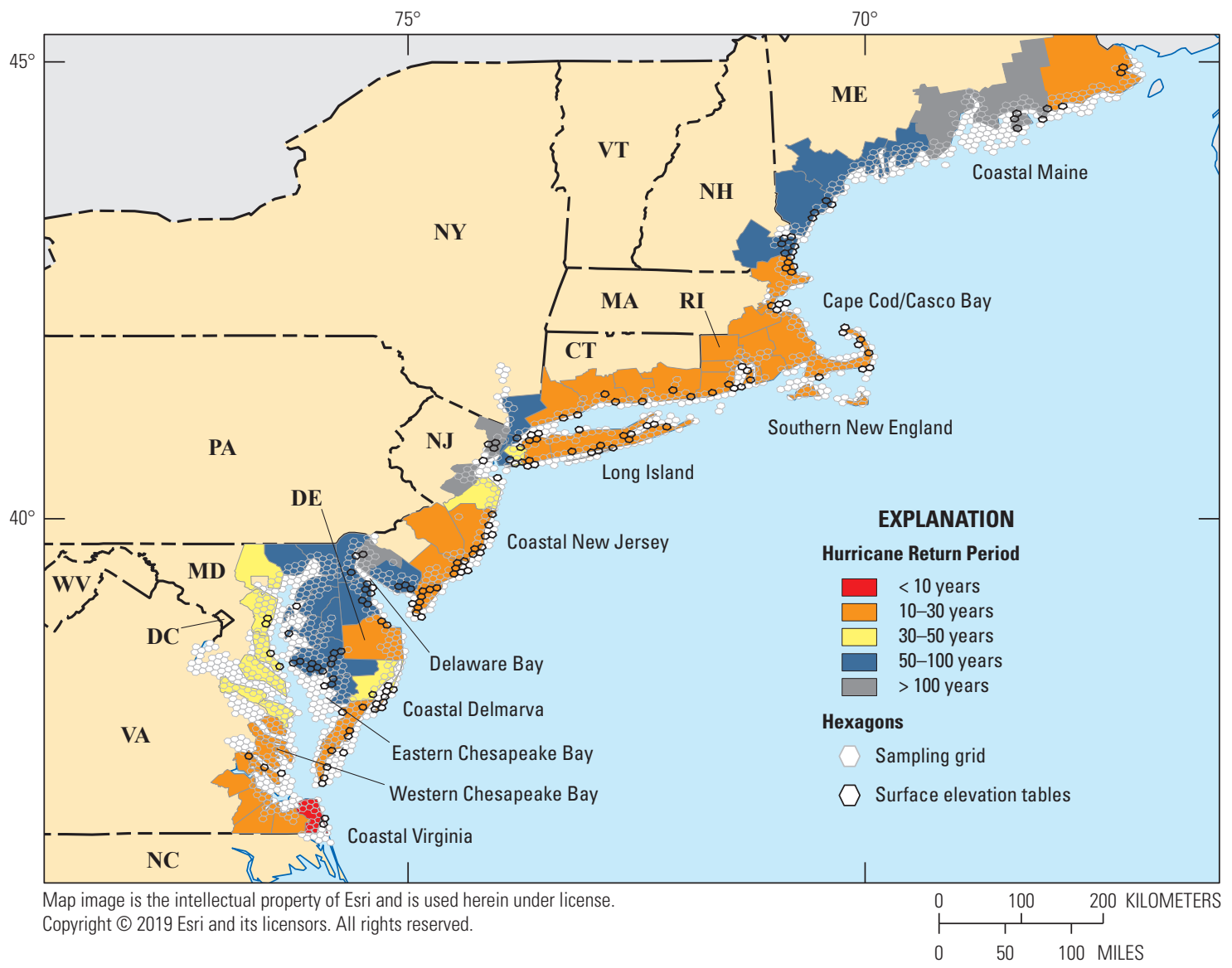

Figure 21. Hurricane return period (based on National Hurricane Center hurricane strike dataset from 1900-2009 for U.S. coastal counties) for the study region (Virginia to Maine, inclusive) with hexagon (40 square kilometers) sampling grid and hexagons with surface elevation table-marker horizon (SET-MH) stations indicated. Note that the hexagon grid is restricted to areas where estuarine emergent marsh is present in the National Wetlands Inventory acquired in 2010; this area includes marsh area along open water that is outside of terrestrial county boundaries. 
are several steps individual data collectors can take to improve the quality of their SET-MH data and its potential for inclusion in future regional data analyses. First, collect data on a regular multi-seasonal basis to develop long-term data records. The single largest reason for data being excluded from our analysis was that data records were less than 3 years duration, largely as a result of stations being installed less than 3 years prior to the storm. Data from these stations will be available for use in future regional assessments so long as regular data collection continues. Furthermore, data collection should occur in multiple seasons to allow better comparisons to poststorm readings (table 3 ) and should be conducted before and after severe storm events. Other data quality factors to consider include diligent quality assessment/quality control checks to minimize data processing time, storing the data in an R-user friendly format, conducting routine elevation surveys to certify the stability of the SET benchmarks, and where regional networks have been established, standardizing data collection of potential covariates (for example, wetland elevation within the tidal frame) by all data holders in the region.

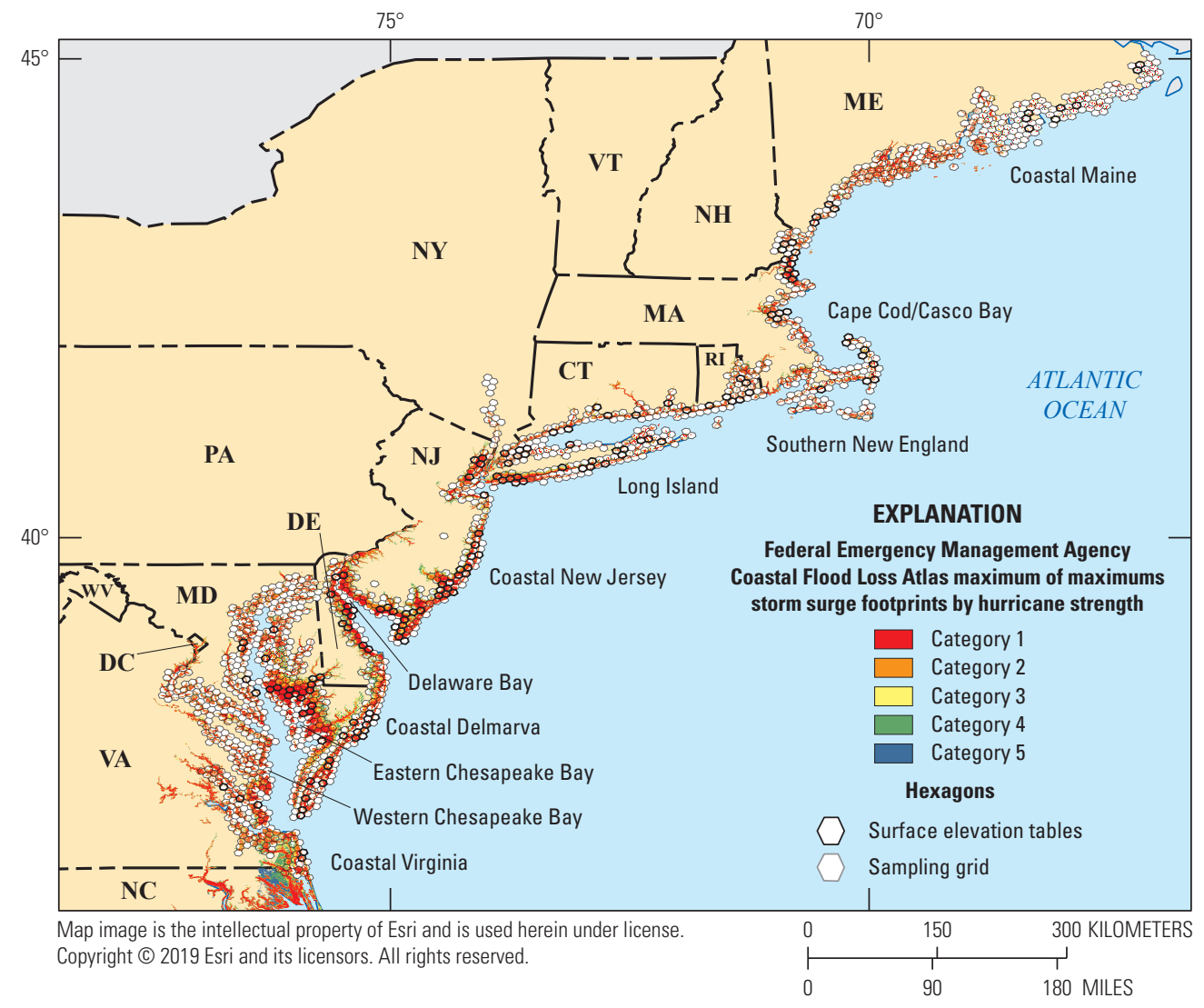

Figure 22. Predicted worst-case scenario storm surge footprints by hurricane storm strength, from the Federal Emergency Management Agency (FEMA) Coastal Flood Loss Atlas SLOSH (Sea, Lake, and Overland Surges from Hurricanes) model maximum of maximums (MOMs) for the study region (Virginia to Maine, inclusive) with hexagon (40 square kilometers) sampling grid and hexagons with surface elevation table-marker horizon (SET-MH) stations indicated. Color coding is cumulative, where red is flooded by hurricanes of category 1 and above, orange by category 2 and above, yellow by category 3 and above, and green by category 4 and above. FEMA SLOSH modeling for category 5 hurricanes not completed for areas north of North Carolina. Note that the hexagon grid is restricted to areas where estuarine emergent marsh is present in the National Wetlands Inventory acquired in 2010; this area includes marsh area along open water that is outside of terrestrial FEMA modeling boundaries, which is assumed to be flooded by all categories. 


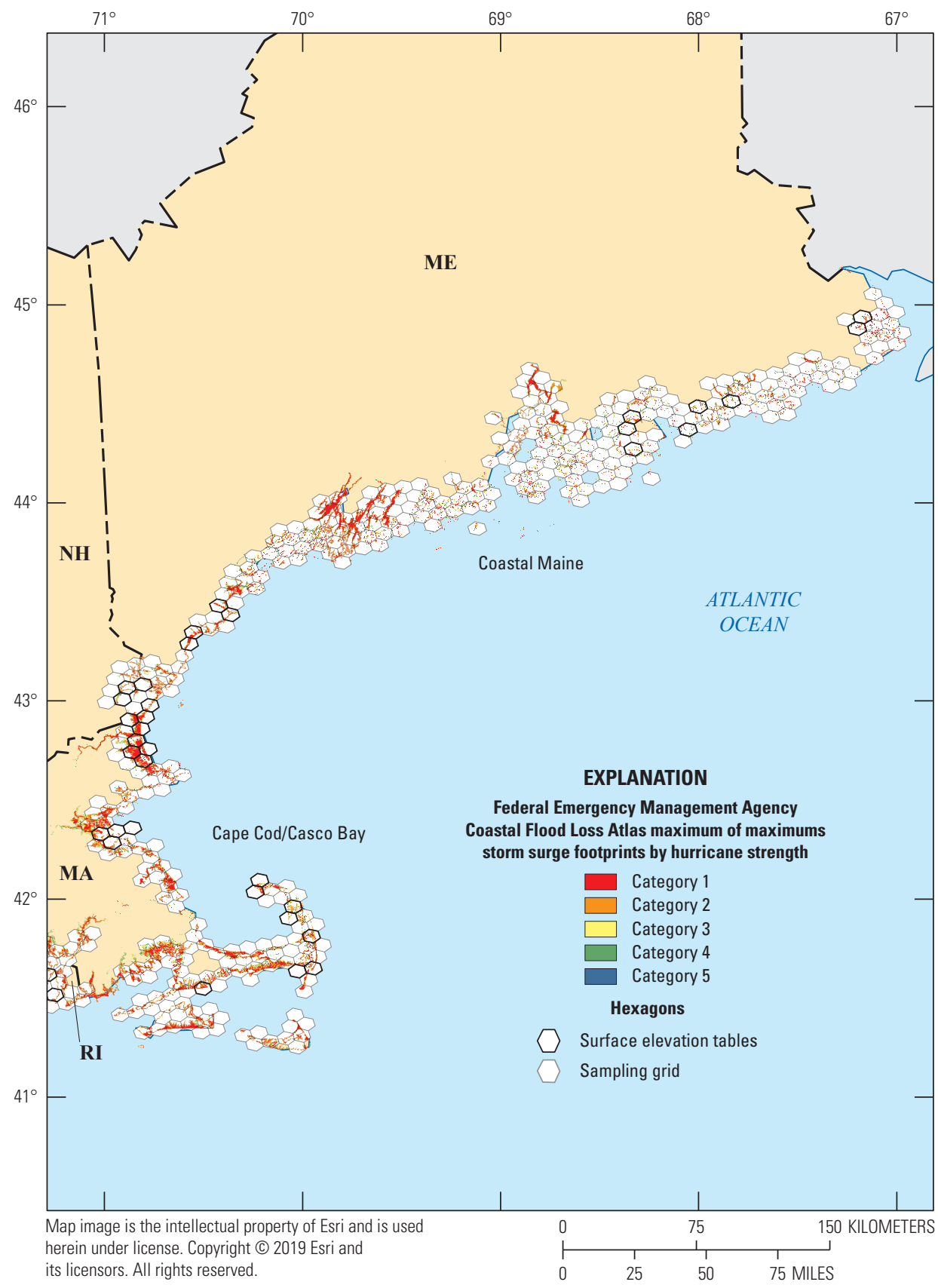

Figure 23. Northern portion of study area predicted worst-case scenario storm surge footprints by hurricane storm strength, from the Federal Emergency Management Agency (FEMA) Coastal Flood Loss Atlas SLOSH (Sea, Lake, and Overland Surges from Hurricanes) model maximum of maximums (MOMs) for Cape Cod/Casco Bay and coastal Maine subregions with hexagon (40 square kilometers) sampling grid and hexagons with surface elevation table-marker horizon (SET-MH) stations indicated. Color coding is cumulative, where red is flooded by hurricanes of category 1 and above, orange by category 2 and above, yellow by category 3 and above, and green by category 4 and above. FEMA SLOSH modeling for category 5 hurricanes not completed for areas north of North Carolina. Note that the hexagon grid is restricted to areas where estuarine emergent marsh is present in the National Wetlands Inventory acquired in 2010; this area includes marsh area along open water that is outside of terrestrial FEMA modeling boundaries, which is assumed to be flooded by all categories. 


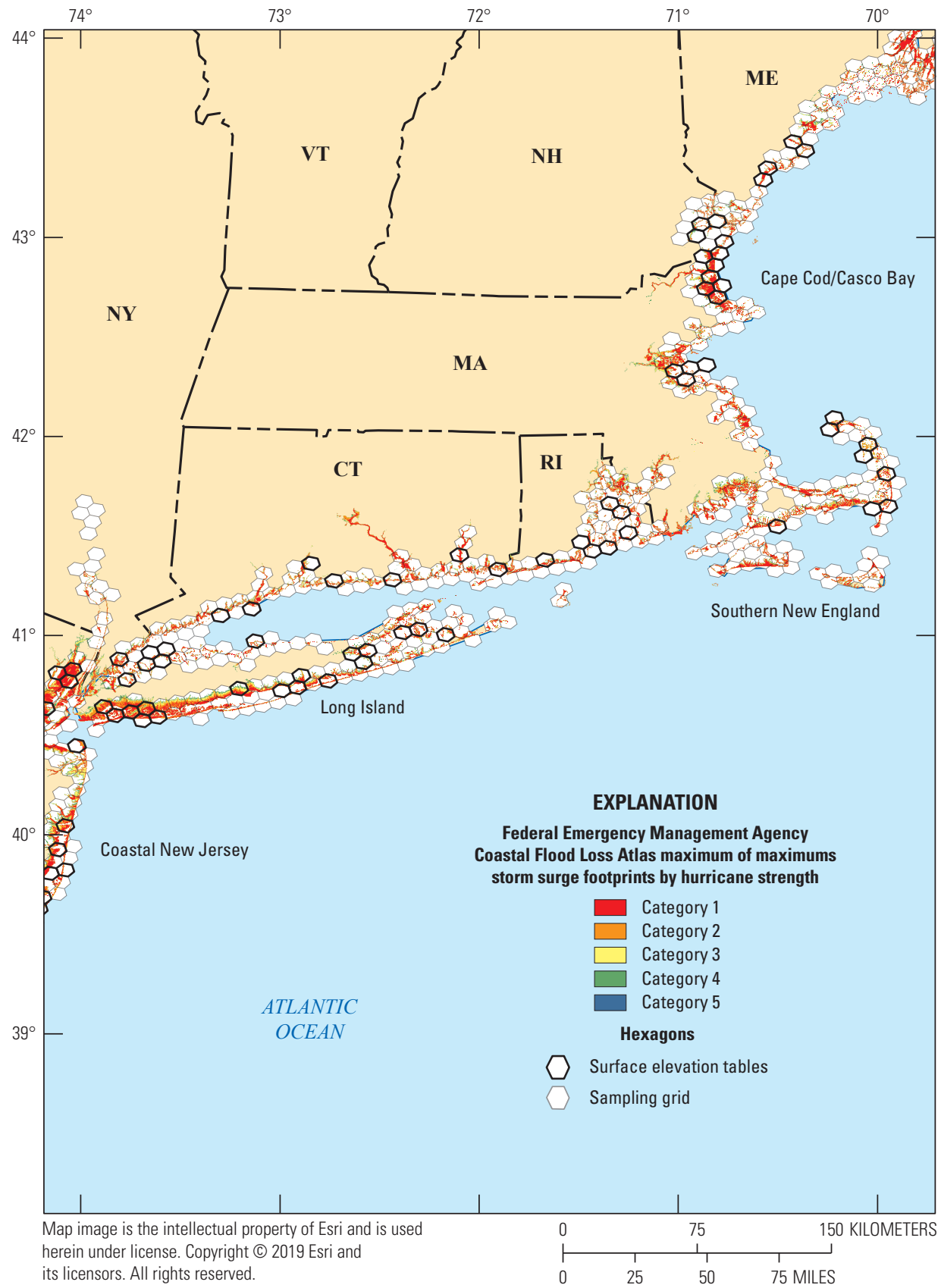

Figure 24. Central portion of study area predicted worst-case scenario storm surge footprints by hurricane storm strength, from the Federal Emergency Management Agency (FEMA) Coastal Flood Loss Atlas SLOSH (Sea, Lake, and Overland Surges from Hurricanes) model maximum of maximums (MOMs) for Cape Cod/Casco Bay, southern New England, Long Island, and part of coastal New Jersey subregions with hexagon (40 square kilometers) sampling grid and hexagons with surface elevation table-marker horizon (SET-MH) stations indicated. Color coding is cumulative, where red is flooded by hurricanes of category 1 and above, orange by category 2 and above, yellow by category 3 and above, and green by category 4 and above. FEMA SLOSH modeling for category 5 hurricanes not completed for areas north of North Carolina. Note that the hexagon grid is restricted to areas where estuarine emergent marsh is present in the National Wetlands Inventory acquired in 2010; this area includes marsh area along open water that is outside of terrestrial FEMA modeling boundaries, which is assumed to be flooded by all categories. 


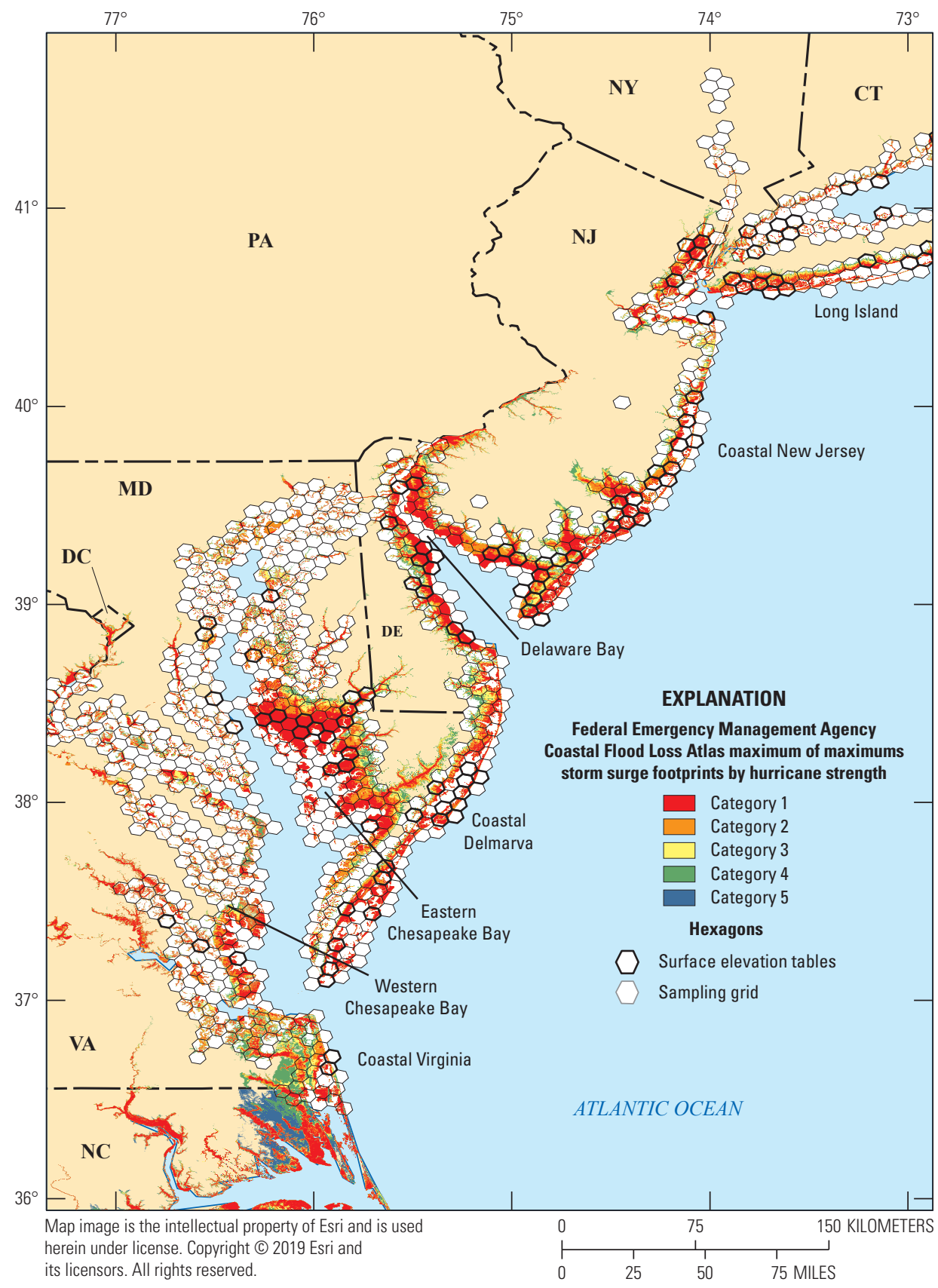

Figure 25. Southern portion of study area predicted worst-case scenario storm surge footprints by hurricane storm strength, from the Federal Emergency Management Agency (FEMA) Coastal Flood Loss Atlas SLOSH (Sea, Lake, and Overland Surges from Hurricanes) model maximum of maximums (MOMs) for coastal Virginia, eastern and western Chesapeake Bay, coastal Delmarva, Delaware Bay, and coastal New Jersey subregions with hexagon (40 square kilometers) sampling grid and hexagons with surface elevation table-marker horizon (SET-MH) stations indicated. Color coding is cumulative, where red is flooded by hurricanes of category 1 and above, orange by category 2 and above, yellow by category 3 and above, and green by category 4 and above. FEMA SLOSH modeling for category 5 hurricanes not completed for areas north of North Carolina. Note that the hexagon grid is restricted to areas where estuarine emergent marsh is present in the National Wetlands Inventory acquired in 2010; this area includes marsh area along open water that is outside of terrestrial FEMA modeling boundaries, which is assumed to be flooded by all categories. 


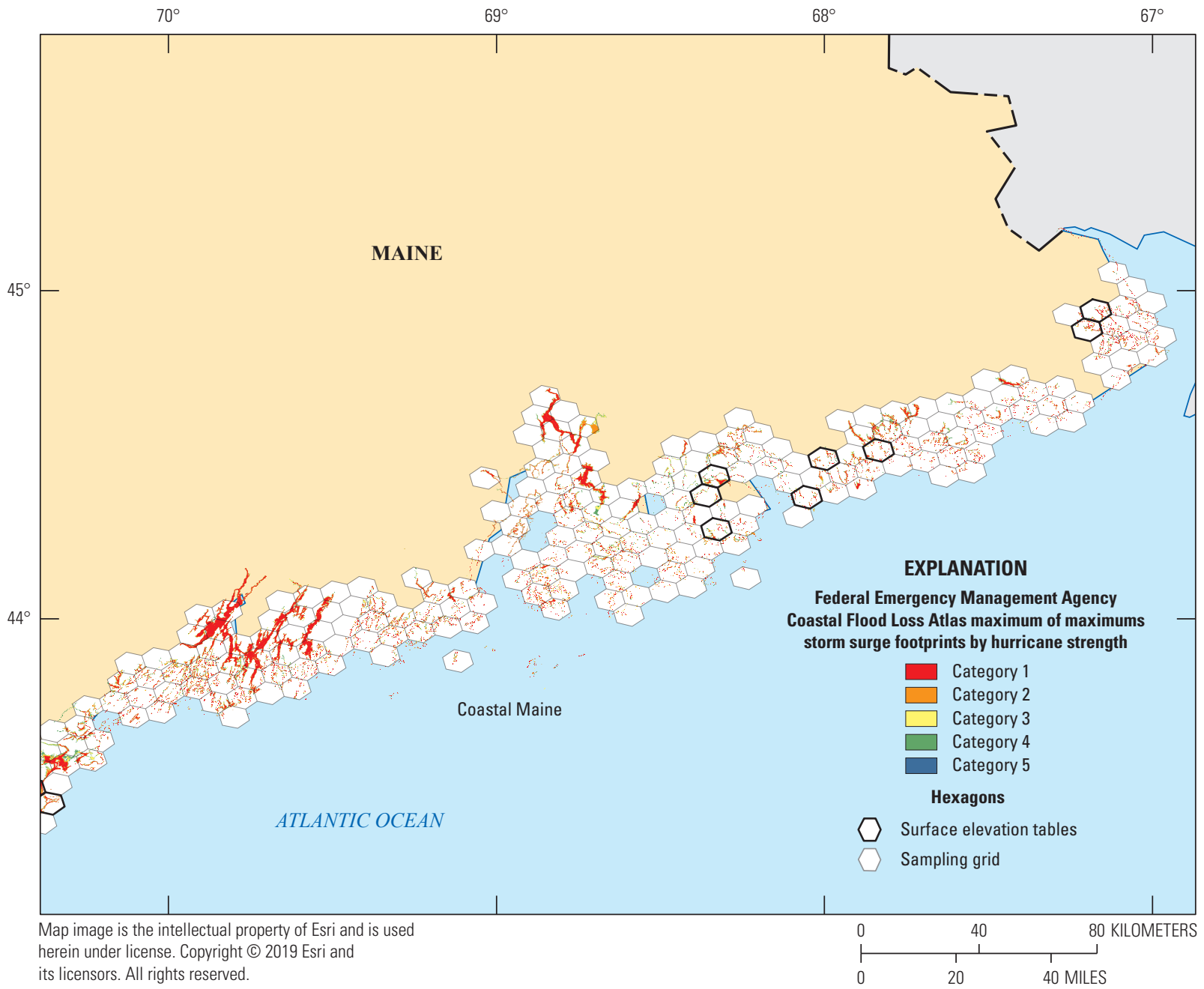

Figure 26. Coastal Maine subregion predicted worst-case scenario storm surge footprints by hurricane storm strength, from the Federal Emergency Management Agency (FEMA) Coastal Flood Loss Atlas SLOSH (Sea, Lake, and Overland Surges from Hurricanes) model maximum of maximums (MOMs) with hexagon (40 square kilometers) sampling grid and hexagons with surface elevation table-marker horizon (SET-MH) stations indicated. Color coding is cumulative, where red is flooded by hurricanes of category 1 and above, orange by category 2 and above, yellow by category 3 and above, and green by category 4 and above. FEMA SLOSH modeling for category 5 hurricanes not completed for areas north of North Carolina. Note that the hexagon grid is restricted to areas where the estuarine emergent marsh is present in the National Wetlands Inventory acquired in 2010; this area includes marsh area along open water that is outside of terrestrial FEMA modeling boundaries, which is assumed to be flooded by all categories. 


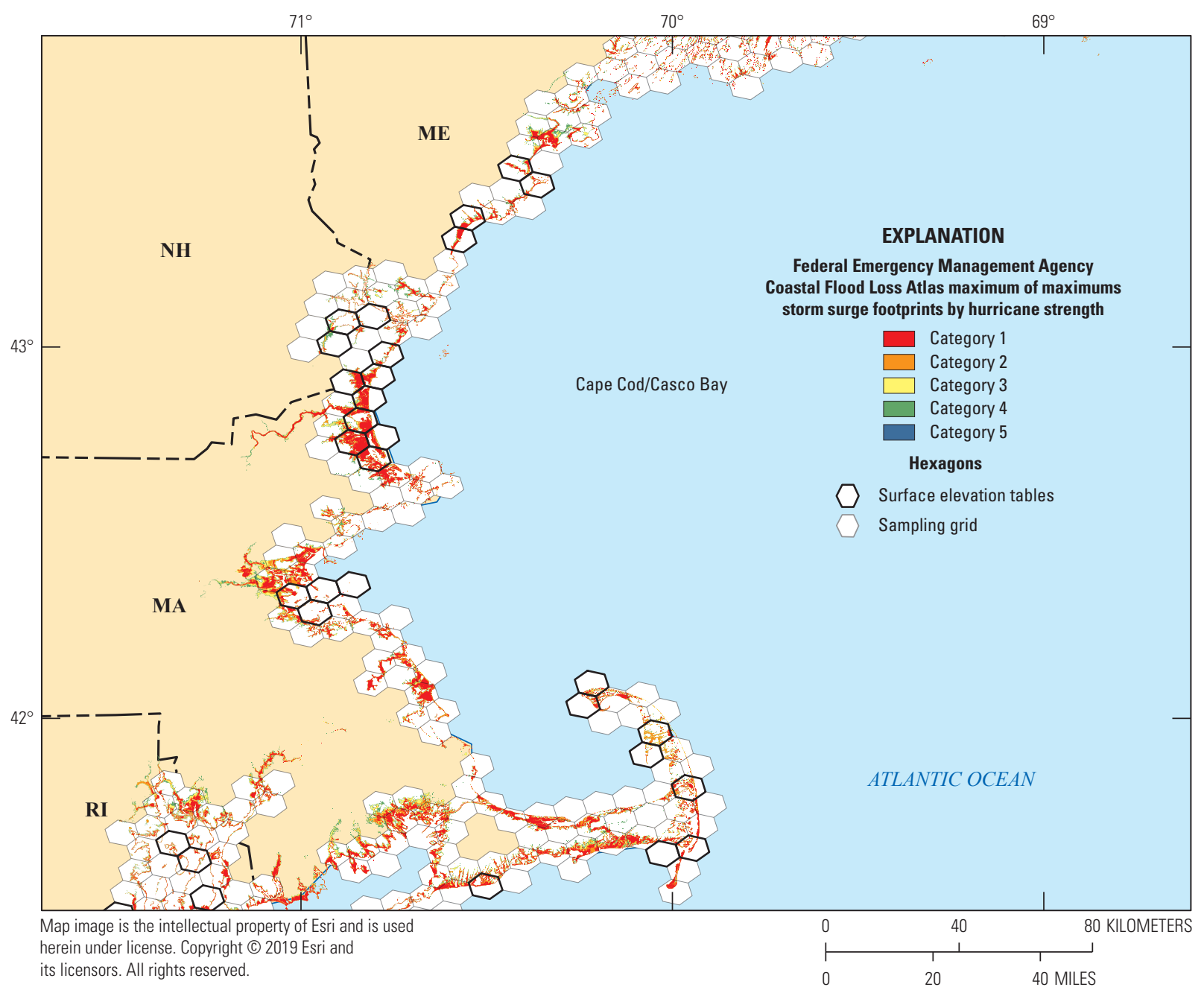

Figure 27. Cape Cod/Casco Bay subregion (and neighboring areas) predicted worst-case scenario storm surge footprints by hurricane storm strength, from the Federal Emergency Management Agency (FEMA) Coastal Flood Loss Atlas SLOSH (Sea, Lake, and Overland Surges from Hurricanes) model maximum of maximums (MOMs) with hexagon (40 square kilometers) sampling grid and hexagons with surface elevation table-marker horizon (SET-MH) stations indicated. Color coding is cumulative, where red is flooded by hurricanes of category 1 and above, orange by category 2 and above, yellow by category 3 and above, and green by category 4 and above. FEMA SLOSH modeling for category 5 hurricanes not completed for areas north of North Carolina. Note that the hexagon grid is restricted to areas where estuarine emergent marsh is present in the National Wetlands Inventory acquired in 2010; this area includes marsh area along open water that is outside of terrestrial FEMA modeling boundaries, which is assumed to be flooded by all categories. 


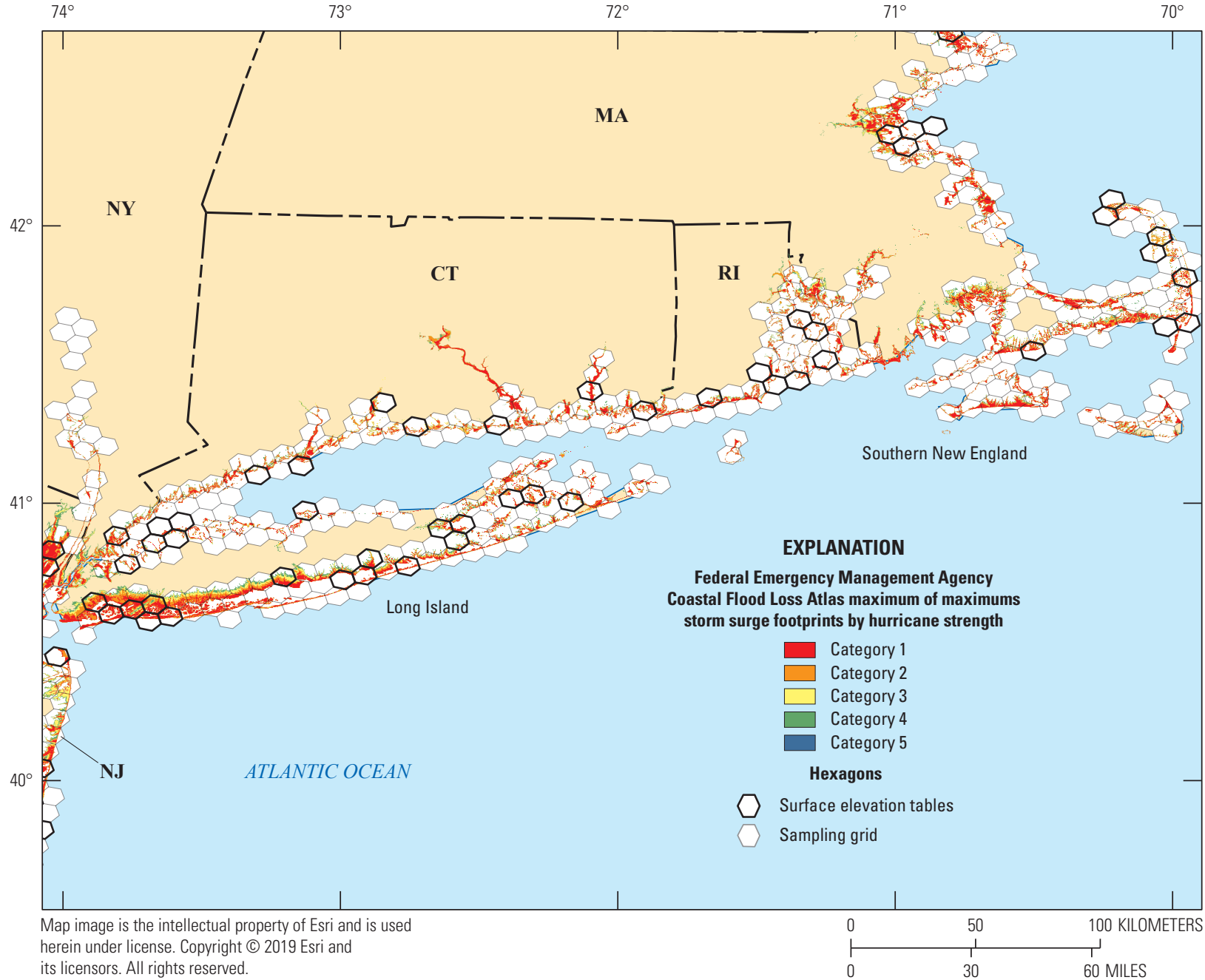

Figure 28. Southern New England subregion (and neighboring areas) predicted worst-case scenario storm surge footprints by hurricane storm strength, from the Federal Emergency Management Agency (FEMA) Coastal Flood Loss Atlas SLOSH (Sea, Lake, and Overland Surges from Hurricanes) model maximum of maximums (MOMs) with hexagon (40 square kilometers) sampling grid and hexagons with surface elevation table-marker horizon (SET-MH) stations indicated. Color coding is cumulative, where red is flooded by hurricanes of category 1 and above, orange by category 2 and above, yellow by category 3 and above, and green by category 4 and above. FEMA SLOSH modeling for category 5 hurricanes not completed for areas north of North Carolina. Note that the hexagon grid is restricted to areas where estuarine emergent marsh is present in the National Wetlands Inventory acquired in 2010; this area includes marsh area along open water that is outside of terrestrial FEMA modeling boundaries, which is assumed to be flooded by all categories. 


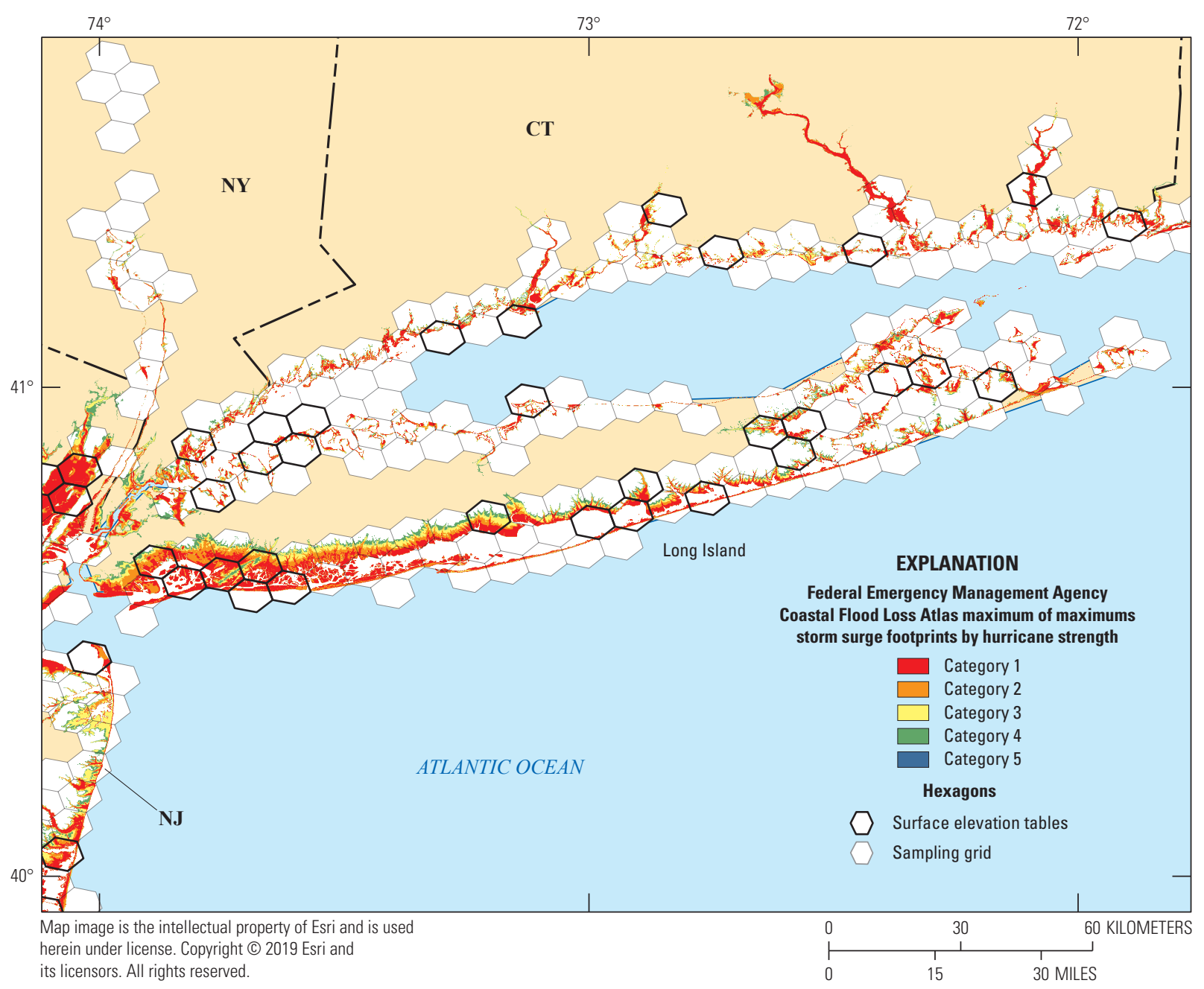

Figure 29. Long Island subregion (and neighboring areas) predicted worst-case scenario storm surge footprints by hurricane storm strength, from the Federal Emergency Management Agency (FEMA) Coastal Flood Loss Atlas SLOSH (Sea, Lake, and Overland Surges from Hurricanes) model maximum of maximums (MOMs) with hexagon (40 square kilometers) sampling grid and hexagons with surface elevation table-marker horizon (SET-MH) stations indicated. Color coding is cumulative, where red is flooded by hurricanes of category 1 and above, orange by category 2 and above, yellow by category 3 and above, and green by category 4 and above. FEMA SLOSH modeling for category 5 hurricanes not completed for areas north of North Carolina. Note that the hexagon grid is restricted to areas where estuarine emergent marsh is present in the National Wetlands Inventory acquired in 2010; this area includes marsh area along open water that is outside of terrestrial FEMA modeling boundaries, which is assumed to be flooded by all categories. 


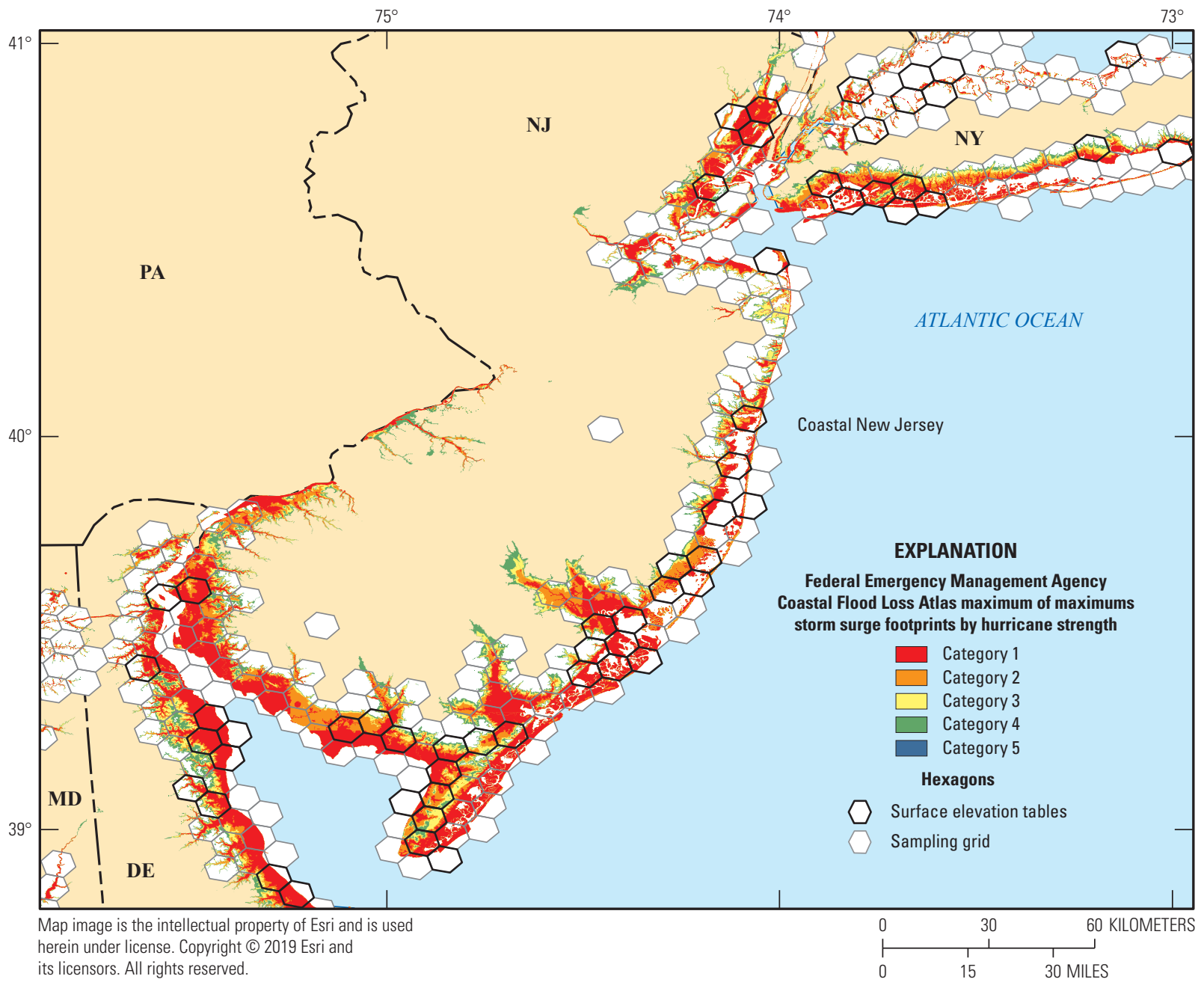

Figure 30. Coastal New Jersey subregion (and neighboring areas) predicted worst-case scenario storm surge footprints by hurricane storm strength, from the Federal Emergency Management Agency (FEMA) Coastal Flood Loss Atlas SLOSH (Sea, Lake, and Overland Surges from Hurricanes) model maximum of maximums (MOMs) with hexagon (40 square kilometers) sampling grid and hexagons with surface elevation table-marker horizon (SET-MH) stations indicated. Color coding is cumulative, where red is flooded by hurricanes of category 1 and above, orange by category 2 and above, yellow by category 3 and above, and green by category 4 and above. FEMA SLOSH modeling for category 5 hurricanes not completed for areas north of North Carolina. Note that the hexagon grid is restricted to areas where estuarine emergent marsh is present in the National Wetlands Inventory acquired in 2010; this area includes marsh area along open water that is outside of terrestrial FEMA modeling boundaries, which is assumed to be flooded by all categories. 


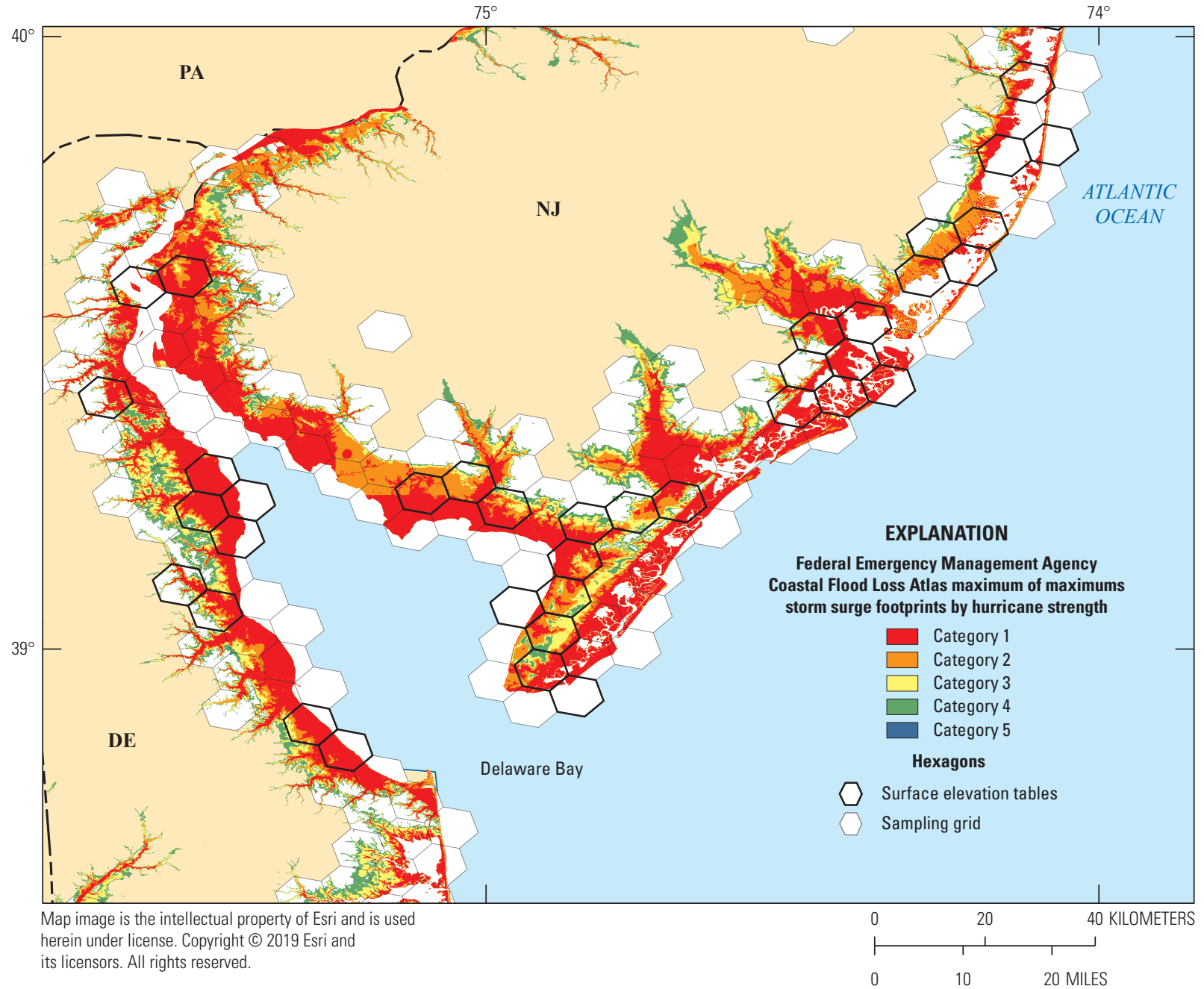

Figure 31. Delaware Bay subregion (and neighboring areas) predicted worst-case scenario storm surge footprints by hurricane storm strength, from the Federal Emergency Management Agency (FEMA) Coastal Flood Loss Atlas SLOSH (Sea, Lake, and Overland Surges from Hurricanes) model maximum of maximums (MOMs) with hexagon (40 square kilometers) sampling grid and hexagons with surface elevation table-marker horizon (SET-MH) stations indicated. Color coding is cumulative, where red is flooded by hurricanes of category 1 and above, orange by category 2 and above, yellow by category 3 and above, and green by category 4 and above. FEMA SLOSH modeling for category 5 hurricanes not completed for areas north of North Carolina. Note that the hexagon grid is restricted to areas where estuarine emergent marsh is present in the National Wetlands Inventory acquired in 2010; this area includes marsh area along open water that is outside of terrestrial FEMA modeling boundaries, which is assumed to be flooded by all categories. 


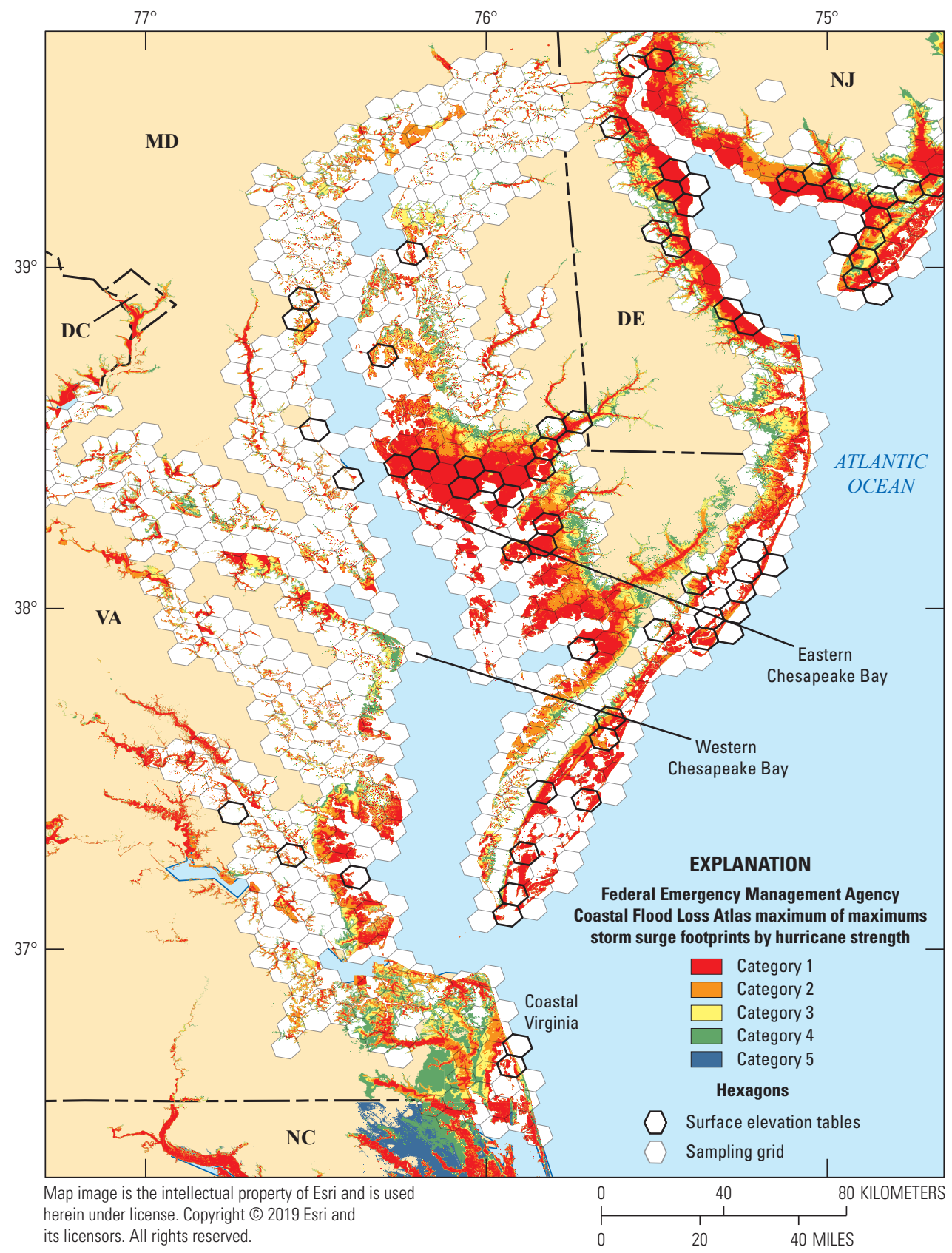

Figure 32. Coastal Virginia and eastern/western Chesapeake Bay subregions (and neighboring areas) predicted worst-case scenario storm surge footprints by hurricane storm strength, from the Federal Emergency Management Agency (FEMA) Coastal Flood Loss Atlas SLOSH (Sea, Lake, and Overland Surges from Hurricanes) model maximum of maximums (MOMs) with hexagon (40 square kilometers) sampling grid and hexagons with surface elevation table-marker horizon (SET-MH) stations indicated. Color coding is cumulative, where red is flooded by hurricanes of category 1 and above, orange by category 2 and above, yellow by category 3 and above, and green by category 4 and above. FEMA SLOSH modeling for category 5 hurricanes not completed for areas north of North Carolina. Note that the hexagon grid is restricted to the area where estuarine emergent marsh is present in the National Wetlands Inventory acquired in 2010; this area includes marsh area along open water that is outside of terrestrial FEMA modeling boundaries, which is assumed to be flooded by all categories. 


\section{Conclusions}

Using data collected from an assemblage of SET-MH stations spread across the northeast U.S. coastline from Virginia to Maine, we evaluated the effects of Hurricane Sandy on marsh elevation trends by comparing prestorm and poststorm data. We hypothesized that the effect of Hurricane Sandy on marsh elevation trends would differ by position relative to landfall (right or left) and distance from landfall in southern New Jersey, as both these variables influence the presence or absence of storm surge as a result of the physical characteristics of tropical cyclones (fig. 4). As expected, storm surge strength and extent were greater to the right of landfall in the northeast quadrant of the storm, compared to the left of landfall. Thus, the interaction of position relative to landfall with distance from landfall significantly influenced marsh elevation trends (fig. 15), indicating significant spatial variation in Hurricane Sandy effects and potential resilience to future storms across the region.

The majority of SET stations had a poststorm deviation from the expected elevation change trend that was within a range commonly observed in prestorm data $(<5 \mathrm{~mm})$. For the SET stations where deviation from the expected trend was greater than $5 \mathrm{~mm}$, position relative to landfall had a significant influence. More marshes located to the left of landfall, where storm surge was less extensive and less deep, had a significant and greater deviation in their elevation trend that was more likely to be positive (elevation gain), compared to marshes located to the right of landfall where the surge was more extensive and deeper. Fewer marshes located to the right of landfall had a significant deviation in their elevation trend, and that trend was more likely to be negative (elevation loss). In addition, positive trends (elevation gain) were lower compared to left of landfall. The cause for this finding apparently is directly related to storm surge impacts on marsh sediment deposition. Other researchers (Gardner and others, 1991, 1992; Quirk, 2016) have shown that 3- to 4-m-deep storm surge results in sediment deposition in habitats inland of coastal marshes but less so in the marshes themselves, and the deep surge water apparently protects the marsh surface from erosive forces related to currents and waves that would affect more shallowly flooded surfaces. Substrate compaction by the storm surge overburden may have contributed to elevation loss in marshes located to the right of landfall, as has occurred in other marshes during previous storms (Cahoon, 2006), but this was not measured because marker horizon data were not available from all sites. In contrast, wind-driven flooding of sediment laden water pushed into the headwaters of rivers and small bays on the east shore of Chesapeake Bay associated with an $\sim 1$-m surge resulted in more prevalent sediment deposition and elevation gain on the marsh surfaces there. Consequently, as a result of Hurricane Sandy, more marshes located left of landfall (for example, Chesapeake Bay region) gained more elevation capital (Cahoon and Guntenspergen, 2010), and hence resilience, than marshes located to the right of landfall.
Even though marsh settings were separated geographically with more back-barrier lagoon settings right of landfall and estuarine marsh left of landfall, estuarine marsh setting did not influence marsh elevation trends or the presence/absence of storm surge (fig. 15). The spatial characteristics of the storm apparently overwhelmed any influence that geomorphic setting had on storm impact.

Lastly, we developed a framework that will enable conversion of the opportunistic assemblage of 965 stations in the northeast United States into a strategic monitoring network designed to address specific climate change impacts and related phenomena identified by land managers and stakeholders. To accomplish this, we evaluated the spatial distribution and density of SET-MH stations in relation to geographic coverage, marsh setting, availability of public land, and historical storm surge footprints and hurricane return intervals in order to identify gaps in our understanding of risk and our ability to assess it. The analyses revealed that the general geographic coverage of SET stations is limited, given the low percentage of marsh patches with stations, low density of stations, and the clumped distribution of stations in 8 of the 10 predefined subregions. Also, spatial coverage of the two dominant geomorphic settings in a subregion is often skewed to one of the settings, and the distribution of stations in wetlands with a high probability of hurricane strikes and storm surge impacts is often limited and uneven. These findings can be used by managers and planners to inform the creation of a strategic monitoring network by providing a guide to future SET station installations at regional and local scales, the results from which can inform management and adaptation efforts for coastal resources in the region. These management concerns will have to be identified and prioritized by the target audience of this report, the local and regional policymakers and resource managers charged with maintaining critical biological resources. Final plan designs will have to incorporate financial and infrastructural support required to collect and manage the data over the long term.

\section{References Cited}

American Littoral Society, 2012, Assessing the impacts of Hurricane Sandy on coastal habitats: Final report to The National Fish and Wildlife Foundation, December 17, 2012, p. 58, accessed January 23, 2013, at https://www.nfwf. org/hurricanesandy/Documents/Hurricane-Sandy-CoastalHabitats.pdf.

Bender, M.A., Knutson, T.R., Tuleya, R.E., Sirutis, J.J., Vecchi, G.A., Garner, S.T., and Held, I.M., 2010, Modeled impact of anthropogenic warming on the frequency of intense Atlantic hurricanes: Science, v. 327, p. 454-458.

Bivand, R., Pebesma, E., and Bubio, V.G., 2013, Applied spatial data analysis with R ( $2 \mathrm{~d}$ ed.): New York, Springer Press, $405 \mathrm{p}$. 
Bivand, R., and Piras, G., 2015, Comparing implementations of estimation methods for spatial econometrics: Journal of Statistical Software, v. 63, no. 18, p. 1-36, accessed November 2016 at http://www.jstatsoft.org/v63/i18/.

Blake, E.S., Kimberlain, T.B., Berg, R.J., Cangialosi, J.P., and Beven, J.L., II, 2013, Tropical cyclone report, Hurricane Sandy (AL182012) 22-29 October 2012: National Oceanic and Atmospheric Administration, National Hurricane Center, $157 \mathrm{p}$.

Blum, L., Christian, R., Brinson, M., and Willis, P., 2017, Surface elevation data for the Upper Phillips Creek Marsh at the Virginia Coast Reserve, 1998: Virginia Coast Reserve Long-Term Ecological Research Project Data Publication knb-lter-vcr.148.23, accessed April 2014 at https://doi. org/10.6073/pasta/427e78ec51022e1ab667c6ce206b9025.

Booth, J.F., Rieder, H.E., and Kushnir, Y., 2016, Comparing hurricane and extratropical storm surge for the Mid-Atlantic and Northeast Coast of the United States for 1979-2013: Environmental Research Letters, v. 11, December 2016 at https://iopscience.iop.org/ article/10.1088/1748-9326/11/9/094004/meta.

Boumans, R.M.J., and Day, J.W., Jr., 1993, High precision measurements of sediment elevation in shallow coastal areas using a sedimentation-erosion table: Estuaries, v. 16, p. $375-380$.

Bourke, P. [2015], Pointline: Paul Bourke web page, accessed September 2015 at http://paulbourke.net/geometry/pointlineplane/pointline.r.

Burnham, K.P., and Anderson, D.R., 2002, Model selection and multimodel inference-A practical information theoretic approach ( $2 \mathrm{~d}$ ed.): New York, Springer, $488 \mathrm{p}$.

Cahoon, D.R., 2006, A review of major storm impacts on coastal wetland elevations: Estuaries and Coasts, v. 29, no. 6, p. 889-898.

Cahoon, D.R., 2015, Estimating relative sea-level rise and submergence potential at a coastal wetland: Estuaries and Coasts, v. 38, p. 1077-1084.

Cahoon, D.R., and Guntenspergen, G.R., 2010, Climate change, sea-level rise, and coastal wetlands: National Wetlands Newsletter, v. 32, no. 1, p. 8-12.

Cahoon, D.R., Hensel, P., Rybczyk, J., McKee, K.L., Proffitt, C.E., and Perez, B.C., 2003, Mass tree mortality leads to mangrove peat collapse at Bay Islands, Honduras after Hurricane Mitch: Journal of Ecology, v. 91, p. 1093-1105.

Cahoon, D.R., Lynch, J.C., Hensel, P., Boumans, R., Perez, B.C., Segura, B., and Day, J.W., 2002a, High-precision measurements of wetland sediment elevation-I. Recent improvements to the sedimentation-erosion table: Journal of Sedimentary Research, v. 72 , no. 5, p. 730-733.
Cahoon, D.R., Lynch, J.C., Perez, B.C., Segura, B., Holland, R.D., Stelly, C., Stephenson, G., and Hensel, P., 2002b, High-precision measurements of wetland sediment elevation-II. The rod surface elevation table: Journal of Sedimentary Research, v. 72, no. 5, p. 734-739.

Cahoon, D.R., Lynch, J.C., Roman, C., Schmit, J.P., and Skidds, D., 2019, Evaluating the relationship among wetland vertical development, elevation capital, sea-level rise and tidal marsh sustainability: Estuaries and Coasts, v. 42, p. $1-15$.

Cahoon, D.R., Reed, D.J., and Day, J.W., 1995a, Estimating shallow subsidence in microtidal salt marshes of the southeastern United States-Kaye and Barghoorn revisited: Marine Geology, v. 128, no. 1-2, p. 1-9.

Cahoon, D.R., Reed, D.J., Day, J.W., Steyer, G.D., Boumans, R.M., Lynch, J.C., McNally, D., and Latif, N., 1995b, The influence of Hurricane Andrew on sediment distribution in Louisiana coastal marshes: Journal of Coastal Research, SI 21, p. 280-294.

Cahoon, D.R., Reed, D.J., Kolker, A., Brinson, M.M., Stevenson, J.C., Riggs, S., Christian, R., Reyes, E., Voss, C., and Kunz, D., 2009, Coastal wetland sustainability, chap. 4 of Titus, J.G. (coordinating lead author), Anderson, K.E., Cahoon, D.R., Gill, S., Thieler, E.R., and Williams, S.J., (lead authors), Coastal sensitivity to sea-level rise-A focus on the mid-Atlantic region: U.S. Environmental Protection Agency, p. 57-72.

Cain, M.R., and Hensel, P.F., 2017, Wetland elevations at subcentimeter precision-Exploring the use of digital barcode leveling for elevation monitoring: Estuaries and Coasts, v. 41 , no. 2 , p. $582-591$.

Callaway, J.C., Cahoon, D.R., and Lynch, J.C., 2013, The surface elevation table-Marker horizon method for measuring wetland accretion and elevation dynamics, chap. 46 of DeLaune, R.D., Reddy, K.R., Richardson, C.J., and Megonigal, J.P., eds., Methods in biogeochemistry of wetlands: Madison, Wis., Soil Science Society of America, SSSA Book Series 10, p. 901-918.

Conway, C.J., and Droege, S., 2006, A unified strategy for monitoring changes in abundance of birds associated with North American tidal marshes, in Greenberg, R., Maldonado, J.E., Droege, S., and McDonald, M.V., eds., Terrestrial vertebrates of tidal marshes-Evolution, ecology, and conservation: Studies in Avian Biology, no. 32, p. 282-297.

Davis, R.E, and Dolan, R., 1993, Nor'easters: American Scientist, v. 81, p. 428-439. 
Dennison, W.C., Saxby, T., and Walsh, B.M., eds., 2012, Responding to major storm impacts - Chesapeake Bay and Delmarva Coastal Bays: Integration \& Application Network, University of Maryland Center for Environmental Science, 16 p., accessed January 23, 2013, at https:// mdcoastalbays.org/files/pdfs_pdf/HurricaneSandyAssessment-Final-1.pdf.

Dowle, M., Srinivasan, A., Short, T., and Lianoglou, S., with contributions from Saporta, R., and Antonyan, E., 2015, data.table-Extension of data.frame (v. 1.9.6): R package, accessed March 2017 at https://CRAN.R-project.org/ package $=$ data.table.

Emanuel, K.A., 2013, Downscaling CMIP5 climate models show increased tropical cyclone activity over the 21 st century: Proceedings of the National Academy of Sciences of the United States of America, v. 110, p. 12219-12224.

Ezer, T., and Atkinson, L.P., 2014, Accelerated flooding along the U.S. east coast - On the impact of sea-level rise, tides, storms, the Gulf Stream, and the North Atlantic Oscillations: Earth's Future, v. 2, p. 362-382.

Federal Emergency Management Agency [2015a], FEMA Modeling Task Force (MOTF) Hurricane Sandy impact analysis: Federal Emergency Management Agency web page, accessed February 29, 2015, at http://www.arcgis. com/home/item.html?id=307dd522499d4a44a33d7296a5d a5ea0.

Federal Emergency Management Agency, 2015b, FEMA Coastal Flood Loss Atlas (v. 3.01): Federal Emergency Management Agency, accessed July 29, 2015, at https:// fema. maps.arcgis.com/home/item.html?id=b4ae0b4278944 7b18c4b919682b848ad.

Folke, C., Carpenter, S., Walker, B., Scheffer, M., Elmqvist, T., Gunderson, L., and Holling, C.S., 2004, Regime shifts, resilience and biodiversity in ecosystem management: Annual Review of Ecology, Evolution, and Systematics, v. 35 , p. $557-581$.

Forbes, C., Rhome, J., Mattocks, C., and Taylor, A., 2014, Predicting the storm surge threat of Hurricane Sandy with the National Weather Service SLOSH Model: Journal of Marine Science and Engineering, v. 2, p. 437-476.

Fox, J., and Weisberg, S., 2011, An R companion to applied regression ( $2 \mathrm{~d}$ ed.): Thousand Oaks, Calif., Sage Publications, $449 \mathrm{p}$.

Gardner, L.R., Michener, W.K., Kjerfve, B., and Karinshak, D.A., 1991, The geomorphic effects of Hurricane Hugo on an undeveloped coastal landscape at North Inlet, South Carolina: Journal of Coastal Research, special issue 8, p. 181-186.
Gardner, L.R., Michener, W.K., Williams, T.M., Blood, E.R., Kjerfve, B., Smock, L.A., Lipscomb, D.J., and Gresham, C., 1992, Disturbance effects of Hurricane Hugo on a pristine coastal landscape - North Inlet, South Carolina, USA: Netherlands Journal of Sea Research, v. 30, p. 249-263.

Grace, J.B., Schoolmaster, Jr., D.R., Guntenspergen, G.R., Little, A.M., Mitchell, B.R., Miller, K.M., and Schweiger, E.W., 2012, Guidelines for a graph-theoretic implementation of structural equation modeling: Ecosphere, v. 3, no. 8 , 44 p., accessed August 2016 at http://dx.doi.org/10.1890/ ES12-00048.1.

Grubel, C., Waldman, J., Lodge, J., and Suszkowski, D., 2012, Rapid assessment of habitat and wildlife losses from Hurricane Sandy in the Hudson Raritan Estuary: Report by the Hudson River Foundation to The National Fish and Wildlife Foundation, December 12, 2012, 22 p. accessed January 23, 2013, at http://www.hudsonriver.org/download/HRF\%20 RAP\%20Final\%20Report\%20-\%20Sent\%2012-21-12.pdf.

Hall, T.M., and Sobel, A.H., 2013, On the impact angle of Hurricane Sandy's New Jersey landfall: Geophysical Research Letters, v. 40, p. 2312-2315.

Hauser, S., Meixler, M.S., and Laba, M., 2015, Quantification of impacts and ecosystem services loss in New Jersey coastal wetlands due to Hurricane Sandy storm surge: Wetlands v. 35, p. 1137-1148.

Horton, R.M., Gornitz, V., Bader, D.A., Ruane, A.C., Goldberg, R., and Rosenzweig, C., 2011, Climate hazard assessment for stakeholder adaptation planning in New York City: Journal of Applied Meteorology and Climatology, v. 50, p. 2247-2266.

Horton, R., Yohe, G., Easterling, W., Kates, R., Ruth, M., Sussman, E., Whelchel, A., Wolfe, D., and Lipschultz, F., 2014, Chapter 16-Northeast, in Melillo, J.M., Richmond, T.C., and Yohe, G.W., eds., Climate change impacts in the United States-The third National climate assessment: U.S. Global Change Research Program, p. 371-395, accessed March 2015 at http://nca2014.globalchange.gov

Kemp, A.C., Hill, T.D., Vane, C.H., Cahil, N., Orton, P.M., Talke, S.A., Parnell, A.C., Sanborn, K., and Hartig, E.K., 2017, Relative sea-level trends in New York City during the past 1500 years: The Holocene, v. 27, no. 8, p. 1169-1186.

Kemp, A.C., and Horton, B.P., 2013, Contribution of relative sea-level rise to historical hurricane flooding in New York City: Journal of Quaternary Science, v. 28, no. 6, p. 537-541.

Knutson, T.R., McBride, J.L., Chan, J., Emanuel, K., Holland, G., Landsea, C., Held, I., Kossin, J.P., Srivastava, A.K., and Sugi, M., 2010, Tropical cyclones and climate change: Nature Geoscience, v. 3, p. 157-163. 
Leonardi, N., Carnacina, I., Donatelli, C., Ganju, N., Plater, A., Schuerch, M., and Temmerman, S., 2018, Dynamic interactions between coastal storms and salt marshes-A review: Geomorphology, v. 301, p. 92-107.

Lin, N., Kopp, R.E., Horton, B.P., and Donnelly, J.P., 2016, Hurricane Sandy's flood frequency increasing from year 1800 to 2100: Proceedings of the National Academy of Sciences, v. 113, no. 43, p. 12071-12075.

Little, C.M., Horton, R.M., Kopp, R.E., Oppenheimer, M., Vecchi, G.A., and Villarini, G., 2015, Joint projections of US East coast sea level and storm surge: Nature Climate Change, v. 5, p. 1114-1120.

Longenecker, III, H.E.G., 2011, Development and applications of the FEMA Region IV Coastal Flood Loss Atlas: ASCE Solutions to Coastal Disasters Conference 2011, June 26-29, 2011, Anchorage, Alaska, p. 650-665.

Longenecker, R., Bowman, J., Olsen, B., Roberts, S., Elphick, C., Castelli, P., and Shriver, W.G., 2018, Short-term resilience of New Jersey tidal marshes to Hurricane Sandy: Wetlands, v. 38 , no. 3 , p. 565-575.

Lynch, J.C., Hensel, P.F., and Cahoon, D.R., 2015, The surface elevation table and marker horizon technique-A protocol for monitoring wetland elevation dynamics: National Park Service, Natural Resources Report NPS/NCBN/NRR2015/1078, $62 \mathrm{p}$.

Mazerolle, M.J., 2016, AICcmodavg-Model selection and multi-model inference based on (Q)AIC(c) (v. 2.0-4): R package, accessed August 2016 at http://CRAN.R-project. org $/$ package $=$ AICcmodavg.

Middleton, B., 2016, Differences in impacts of Hurricane Sandy on freshwater swamps on the Delmarva Peninsula, Mid-Atlantic Coast, USA: Ecological Engineering, v. 87, p. 62-70.

Moher, D., Liberati, A., Tetzlaff, J., and Altman, D.G., 2009, Preferred reporting items for systematic reviews and metaanalyses-The PRISMA statement: PLoS Medicine, v. 6, no. 6, e1000097, accessed September 2015 at https://doi. org/10.1371/journal.pmed.1000097.

Moller, I., Kudella, M., Rupprecht, F., Spencer, T., Paul, M., van Wesenbeeck, B.K., Wolters, G., Jensen, K., Bouma, T.J., Miranda-Lange, M., and Schimmels, S., 2014, Wave attenuation over coastal salt marshes under storm surge conditions: Nature Geoscience v. 7, p. 727-731.

Narayan, S., Beck, M., Wilson, P., Thomas, C., Guerrero, A., Shepard, C., Reguero, B., Franco, G., Ingram, J., and Trespalacios, D., 2017, The value of coastal wetlands for flood damage reduction in the northeastern USA: Nature Scientific Reports, v. 7, accessed December 2017 at https://www. nature.com/articles/s41598-017-09269-z.
National Aeronautics and Space Administration [2013], Hurricane Sandy (Atlantic Ocean), October 28, 2013: National Aeronautics and Space Administration web page, accessed March 3, 2017, at https://www.nasa.gov/mission_pages/hurricanes/archives/2012/h2012_Sandy.html.

National Oceanic and Atmospheric Administration [2010], County by county hurricane strikes (1900-2009): National Oceanic and Atmospheric Administration, National Hurricane Center web page, last updated February 2010, accessed July 29, 2015, at https://www.nhc.noaa.gov/ms-excel/HurricaneStrikes_20100204.xls.

National Oceanic and Atmospheric Administration, 2014, NOAA/National Hurricane Center preliminary best track tropical cyclone tracks [file: al182012_best_track.zip]: National Oceanic and Atmospheric Administration, National Hurricane Center, accessed July 29, 2015, at http://www. nhc.noaa.gov/gis/.

Pebesma, E.J., and Bivand, R.S., 2005, Classes and methods for spatial data in R: R News, v. 5, no. 2, accessed April 2015 at http://cran.r-project.org/doc/Rnews/.

Peduzzi, P., Chatenoux, B., Dao, H., De Bono, A., Herold, C., Kossin, J., Mouton, F., and Nordbeck, O., 2012, Global trends in tropical cyclone risk: Nature Climate Change, v. 2, p. 289-294.

Quirk, T., 2016, Impact of Hurricane Sandy on salt marshes of New Jersey: Estuarine, Coastal and Shelf Science, v. 183, p. 235-248.

R Core Team, 2016, R-A language and environment for statistical computing: R Foundation for Statistical Computing, Vienna, Austria, accessed August 2015 at https://www.Rproject.org/.

Rachlin, J.W., Stalter, R., Kincaid, D., and Warkentine, B.E., 2017, The effect of Superstorm Sandy on salt marsh vascular flora in the New York bight: Journal of the Torrey Botanical Society, v. 144, no. 1, p. 40-46.

Rangoonwala, A., Enwright, N., Ramsey, E., and Spruce, J., 2016, Radar and optical mapping of surge persistence and marsh dieback along the New Jersey Mid-Atlantic coast after Hurricane Sandy: International Journal of Remote Sensing, v., 37, p. 1692-1713.

Reed, A.J., Mann, M.E., Emanuel, K.A., Lin, N., Horton, B.P., Kemp, A.C., and Donnelly, J.P., 2015, Increased threat of tropical cyclones and coastal flooding to New York City during the anthropogenic era: Proceedings of the National Academy of Sciences, v. 112, no. 41, p. 12610-12615.

Reed, D.J., 2002, Sea-level rise and coastal marsh sustainability-Geological and ecological factors in the Mississippi delta plain: Geomorphology, v. 48, p. 233-243. 
Resio, D.T., and Westerink, J.J., 2008, Modeling the physics of storm surges: Physics Today, v. 61, p. 33-38.

Rosseel, Y., 2012, lavaan-An R package for structural equation modeling: Journal of Statistical Software, v. 48, no. 2, p. 1-36, accessed September 2015 at http://www.jstatsoft. org/v48/i02/.

Rupprecht, F., Moller, I., Paul, M., Kudella, M. Spencer, T., van Wesenbeeck, B.K., Wolters, G., Jensen, K., Bouma, T.J., Miranda-Lange, M., and Schimmels, S., 2017, Vegetation-wave interactions in salt marshes under storm surge conditions: Ecological Engineering, v. 100, p. 301-315.

Sallenger, A.H., Doran, K.S., and Howd, P.A., 2012, Hotspot of accelerated sea-level rise on the Atlantic coast of North America: Nature Climate Change, v. 2, p. 884-888.

Sopkin, K.L., Stockdon, H.F., Doran, K.S., Plant, N.G., Morgan, K.L.M., Guy, K.K., and Smith, K.E.L., 2014, Hurricane Sandy - Observations and analysis of coastal change: U.S. Geological Survey Open-File Report 2014-1088, 54 p., accessed July 2015 at http://dx.doi.org/10.3133/ ofr20141088.

Stevens, D.L., and Olsen, A.R., 2004, Spatially balanced sampling of natural resources: Journal of the American Statistical Association, v. 99, p. 262-278.

Stevenson, J.C., Ward, L.G., and Kearney, M.S, 1988, Sediment transport and trapping in marsh system-Implications of tidal flux studies: Marine Geology, v. 80, p. 37-59.

Sweet, W.V., Kopp, R.E., Weaver, C.P., Obeysekera, J., Horton, R.M., Thieler, E.R., and Zervas, C., 2017, Global and regional sea level rise scenarios for the United States: National Oceanic and Atmospheric Administration Technical Report NOS CO-OPS 083, 55 p., + appendices.

Talke, S.A., Orton, P., and Jay, D.A., 2014, Increasing storm tides in New York Harbor, 1844-2013: Geophysical Research Letters, v. 41, p. 3149-3155.

Tebaldi, C., Strauss, B.H., and Zervas, C.E., 2012, Modelling sea level rise impacts on storm surges along US coasts: Environmental Research Letters, v. 7, no. 1, 11 p.

Valle-Levinson, A., Olabarrieta, M., and Valle, A., 2013, Semi-diurnal perturbations to the surge of Hurricane Sandy: Geophysical Research Letters, v. 40, p. 2211-2217.

Wang, H., Chen, Q., Hu, K., Snedden, G.A., Hartig, E.K., Couvillion, B.R., Johnson, C.L., and Orton, P.M., 2017, Numerical modeling of the effects of Hurricane Sandy and potential future hurricanes on spatial patterns of salt marsh morphology in Jamaica Bay, New York City: U.S. Geological Survey Open-File Report 2017-1016, 43 p., accessed March 2018 at https://doi.org/10.3133/ofr20171016.
Webb, E.L., Friess, D.A., Krauss, K.W., Cahoon, D.R., Guntenspergen, G.R., and Phelps, J., 2013, A global standard for monitoring coastal wetland vulnerability to accelerated sealevel rise: Nature Climate Change, v. 3, no. 5, p. 458-465.

Weist, W.A., Correll, M.D., Olsen, B.J., Elphick, C.S., Hodgman, T.P., Curson, D.R., and Shriver, W.G., 2016, Population estimates for tidal marsh birds of high conservation concern in the northeastern USA from a design-based survey: The Condor, v. 118, p. 274-288.

Wickham H., 2007, Reshaping data with the reshape package: Journal of Statistical Software, v. 21, no. 12, accessed March 2017 at http://www.jstatsoft.org/v21/i12/.

Wickham, H., 2014, Tidy data: Journal of Statistical Software, v. 59, no. 10, accessed March 2017 at http://www.jstatsoft. org/V59/i10/.

Woodruff, J.D., Irish, J.L., and Camargo, S.J., 2013, Coastal flooding by tropical cyclones and sea-level rise: Nature, v. 504, p. 44-52.

Zuur, A.F., Ieno, E.N., Walker, N.J., Saveliev, A.A., and Smith, G.M., 2009, Mixed effects models and extensions in ecology with R: New York, Springer, 574 p. 


\section{Glossary}

accretion The accumulation of matter, both mineral and organic, carried by a river or stream. Vertical accretion refers to the buildup of the sediment substrate, whereas lateral accretion refers to horizontal expansion of the sediment substrate.

covariate An observable, continuous secondary variable that may affect the response variable. Covariates are often used in a statistical model to help control variability, so that the response to the primary factors of interest can be discerned. For example, wetland elevation relative to mean high water is a secondary variable that may help determine the effect of vegetation type on elevation change.

elevation change Change in the height of the wetland surface (positive or negative) relative to the base of the SET mark as measured by the surface elevation table (SET).

hurricane strike Refers to a location where a hurricane strike occurs, if the location passes within the hurricane's strike circle, a circle of 125 nautical mile ( $\mathrm{n} \mathrm{mi}$ ) diameter, centered $12.5 \mathrm{n} \mathrm{mi}$ to the right of the hurricane center (looking in the direction of motion). This circle is meant to depict the typical extent of hurricane force winds, which are approximately $75 \mathrm{n} \mathrm{mi}$ to the right of center and $50 \mathrm{n} \mathrm{mi}$ to the left (from http://www.nhc. noaa.gov/aboutgloss.shtml\#i).

indirect hurricane strike Refers to locations that do not experience a direct hit from a hurricane, but do experience hurricane force winds (either sustained or gusts) or tides of at least 4 feet above normal (from http://www. nhc.noaa.gov/aboutgloss.shtml\#i).

inundation The total water level that occurs on normally dry ground as a result of the storm tide, expressed in terms of height above ground level (from Blake and others, 2013).

marker horizon An artificial soil horizon placed on a wetland surface to measure vertical accretion (in other words, the accumulation of material above the marker horizon). Feldspar is a common marker material.

marsh buffer A designated area surrounding marsh polygons; a buffer allows adjacent marsh in close proximity to be combined into a single marsh patch.

marsh patch Discrete spatial areas of marsh defined by marsh polygons (from National Wetlands Inventory, code E2EM); a 50-meter marsh buffer was created around each marsh polygon, and those polygons with intersecting buffers are considered to be part of the same marsh patch. The 50-m buffer connects polygons that are artificially divided by channels or roads.

marsh polygon Geographic boundary surrounding estuarine emergent marsh identified by the National Wetlands Inventory (code E2EM).

marsh resilience The capacity of a marsh system to maintain function, structure, and feedbacks in the face of disturbance (Folke and others, 2004)

sea-level rise, eustatic Vertical rate of increase in local sea level; typically determined from long-term sea-level records.

sea-level rise, relative The combination of eustatic sea-level rise and local vertical land motion (in other words, isostatic land subsidence or uplift and near surface processes including shallow subsidence and shallow expansion).

SET mark The permanent infrastructure established at a surface elevation table-marker horizon (SET-MH) station, from which SET measurements are taken; also colloquially referred to as a SET benchmark in early SET literature. If an SET mark meets National Geodetic Survey bluebook standards, it can be referred to as a bench mark. There are three types of SET marks: pipe SET mark, deep-rod SET mark (deep RSET mark), and shallowrod SET mark (shallow RSET mark).

shallow expansion The upward movement of the wetland surface relative to the base of the SET mark caused by subsurface expansion of the substrate (for example, dilation water storage or enhanced root growth), calculated as the difference between vertical accretion, as measured by a marker horizon, and elevation change, as measured by the SET (in other words, vertical accretion minus elevation). Shallow expansion only applies to the portion of the substrate above the base of the SET mark and not the portion below it. 
shallow subsidence The sinking or downward movement of the wetland surface relative to the base of the SET mark caused by subsurface compaction or soil shrinkage. It is calculated as the difference between vertical accretion, as measured by a marker horizon, and elevation change, as measured by the SET (in other words, vertical accretion minus elevation). Shallow subsidence only applies to the portion of the substrate above the base of the SET mark, and not the portion below it.

storm surge The abnormal rise of water generated by a storm, over and above the predicted astronomical tide, expressed in terms of height above normal tide levels (from Blake and others, 2013)

storm tide The water level owing to the combination of storm surge and astronomical tide, expressed in terms of height above a vertical datum, for example, the North American Vertical Datum of 1988 or Mean Lower Low Water (from Blake and others, 2013). subsidence The sinking or downward movement of a surface relative to a datum.

surface elevation table (SET) A portable mechanical device that provides high-resolution measurements of relative elevation change in wetland sediments or shallow water bottoms relative to the depth of the SET mark to which it is attached. The original SET was designed to attach to a hollow pipe mark. The rod SET (RSET) was designed to attach to either a stainless steel rod mark (deep RSET mark) or a shallow hollow-legged mark (shallow RSET mark).

surface sediment deposition The process of suspended sediment deposition on the wetland surface; which contributes to wetland vertical accretion.

vertical accretion The building up of a wetland surface through the deposition and accumulation of sediments. See accretion. 


\section{Appendixes 1-3}

\section{Figures}

1.1. A, Photographs of the surface elevation table developed in the $1990 \mathrm{~s}$ and, $B$, the rod surface elevation table developed in the 2000s, deployed on their benchmarks and pin heights being measured.

1.2. A, Photograph showing the spatial relation between the rod surface elevation table mark and feldspar marker horizons established on a recent thin-layer sediment deposit designed to restore elevations in this degraded marsh. $B$, Photograph showing a core taken through a marker horizon revealing the visible feldspar layer, from which vertical accretion is measured

1.3. Diagram of a wetland substrate showing the vertical relation between the measurements of elevation change by the rod surface elevation table (vertical land motion or $\mathrm{VLM}_{\mathrm{w}}$ l and vertical accretion (VA) by the marker horizon

\section{Tables}

2.1. Surface elevation table-marker horizon data

3.1. Summary output for best deviation from expected surface elevation change model (model 15e)

3.2. Summary output for the best storm surge submodel (model 3 ) using eligible surface elevation table dataset 



\section{Appendix 1. The Surface Elevation Table-Marker Horizon Method}

An in-depth and detailed description of the surface elevation table-marker horizon (SET-MH) method is provided in the SET-MH protocol by Lynch and others (2015). For anyone wishing to use this method to measure wetland elevation dynamics, it is recommended that you consult this document before commencing. The following text is a brief overview of the SET-MH method derived from the SET-MH protocol.

\section{Surface Elevation Table}

The surface elevation table (SET) is a portable, mechanical device that attaches to a pipe or rod mark driven permanently into the wetland substrate (fig. 1.1) and provides high-precision measurements of relative elevation change in wetland sediments or shallow water bottoms relative to the base of the pipe or rod mark. The measurements are made by lowering nine pins from the SET device to the wetland surface from as many as eight positions around the mark. The SET is attached to the mark in such a way that it reoccupies the same reference plane in space, and each time readings are taken each pin reoccupies the same point on the wetland surface. Hence, the measurements are repeatable, can be made over long periods of time, and are of sufficiently high resolution to compare to long-term sea level trends measured by tide gages (Cahoon, 2015). Detailed designs of the original (pipe) SET are provided in Boumans and Day (1993) and Cahoon and others (2002a); detailed designs of the Rod SET are in Cahoon and others (2002b) and Callaway and others (2013).

\section{Marker Horizon}

A marker horizon is an artificial soil layer placed on the wetland surface that over time becomes buried and from which vertical accretion can be measured (fig. 1.2A). Numerous materials are used as marker horizons (for example, sand, feldspar, brick dust), but the most common is feldspar because it is (1) bright white and easily distinguishable from the sediments, (2) has a higher density than water, and (3) forms a colloidal layer when wet. A core is taken through the horizon, and the thickness of sediment accumulated above the horizon is measured as vertical accretion (fig. 1.2B). Marker horizons are typically established at an SET station within the immediate vicinity of the SET on the date of the initial SET reading (fig. 1.2A).

\section{Shallow Subsurface Processes}

When used in combination, the SET and MH methods provide information on both surface and below ground processes that influence elevation change (fig. 1.3; Cahoon and others, 1995a). The SET measures elevation change $\left(\mathrm{VLM}_{\mathrm{w}}\right)$ over the depth of the mark that includes both surface accretion and erosion combined with subsurface processes of subsidence or expansion (for example, expansion of the root zone by root growth). The $\mathrm{MH}$ measures near-surface vertical accretion (VA). The difference between VA minus VLM $\mathrm{VL}_{\mathrm{w}}$ indicates the amount of shallow subsidence or expansion occurring between the depth of the MH and base of the SET mark (fig. 1.3). Subsurface process influences on elevation change occurring below the base of the mark are not included in the SET-MH measurements. 

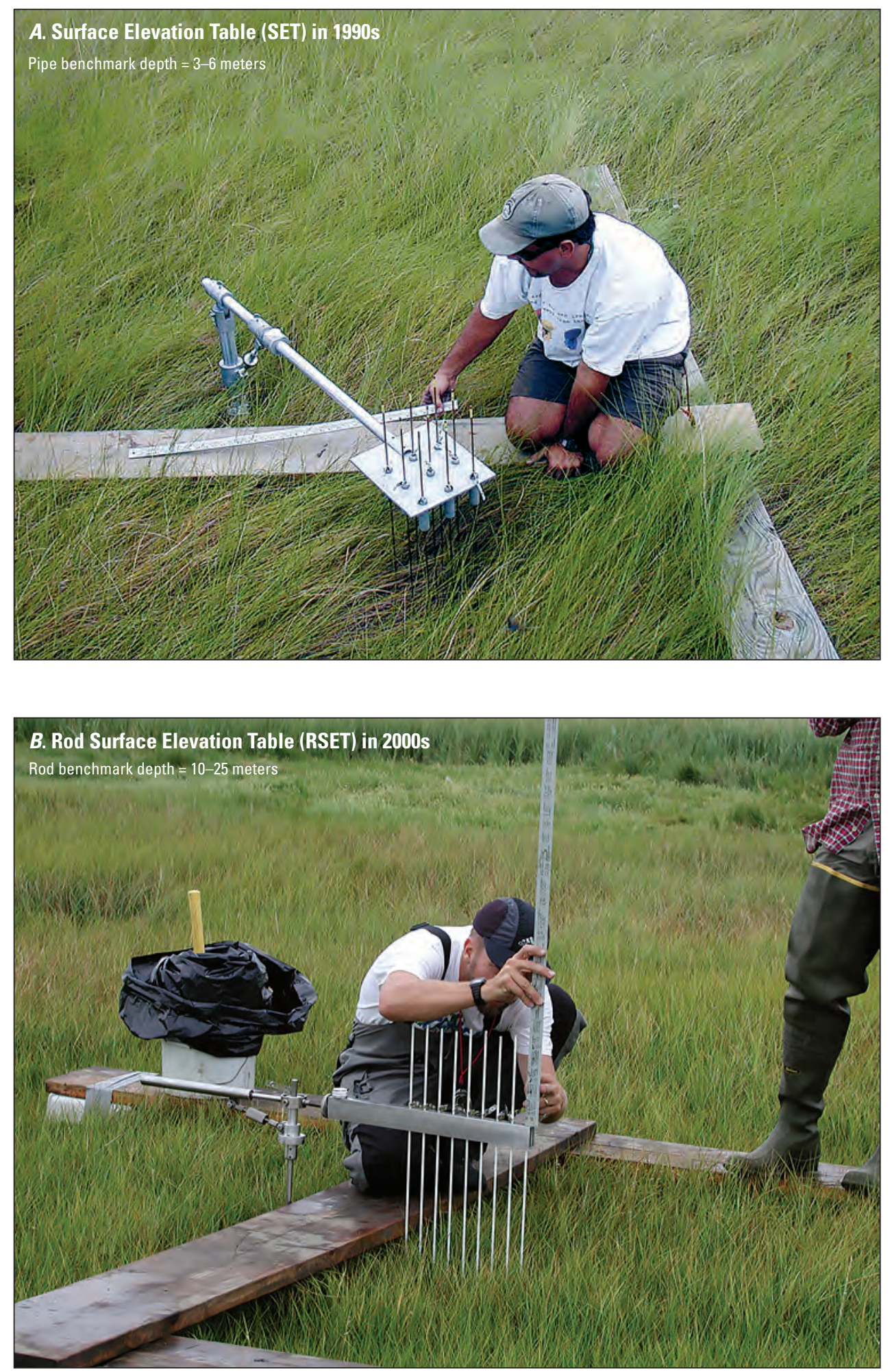

Figure 1.1. A, Photographs of the surface elevation table (SET) developed in the 1990s and, $B$, the rod surface elevation table (RSET) developed in the 2000s, deployed on their benchmarks and pin heights being measured. Photographs by Donald R. Cahoon, U.S. Geological Survey. 

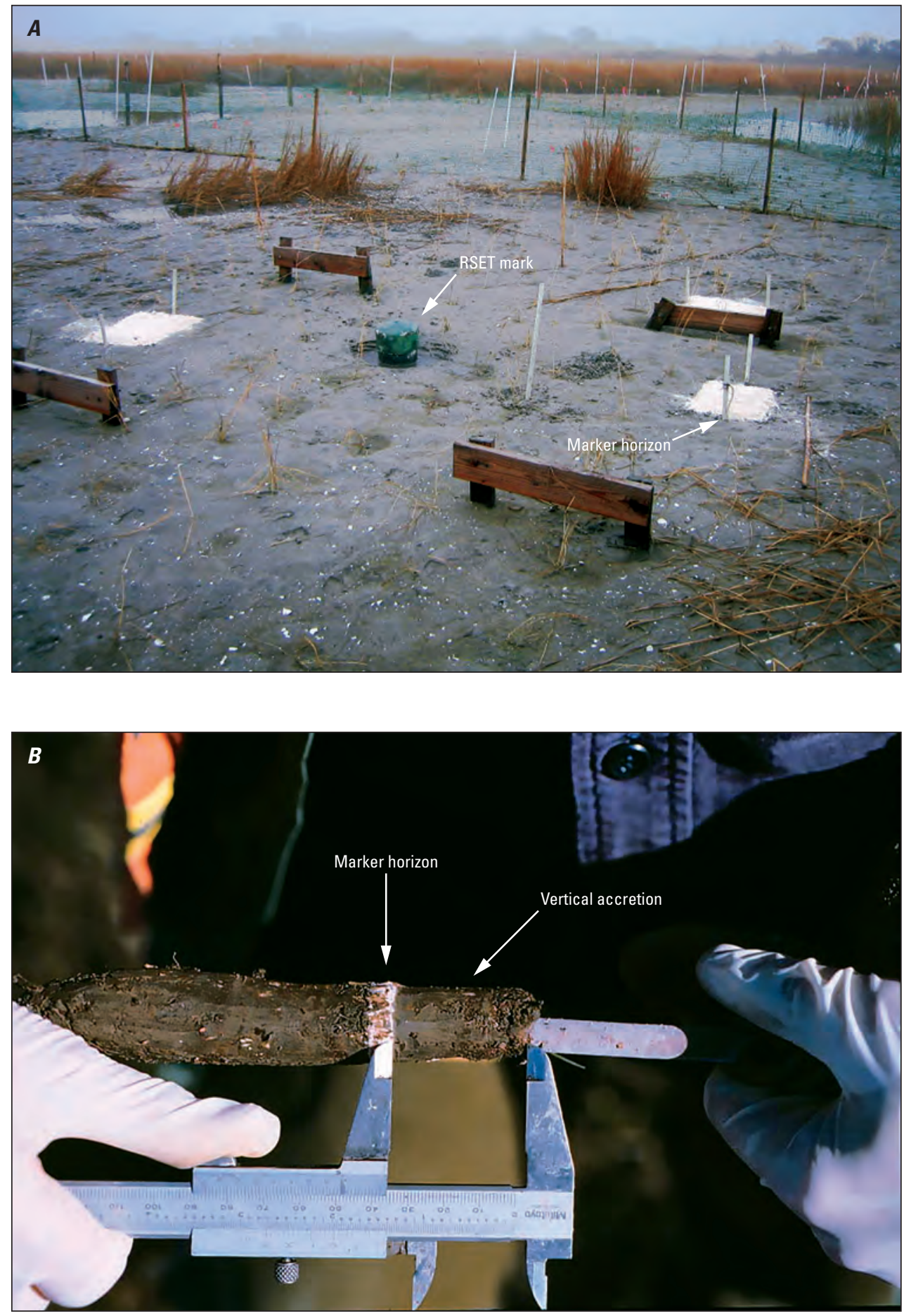

Figure 1.2. A, Photograph showing the spatial relation between the rod surface elevation table (RSET) mark and feldspar marker horizons established on a recent thin-layer sediment deposit designed to restore elevations in this degraded marsh. Photograph by Cahoon and others (2019). Note the RSET benchmark is covered with a cap to protect it during the deposition of dredged material. $B$, Photograph showing a core taken through a marker horizon revealing the visible feldspar layer from which vertical accretion is measured. Photograph by Donald R. Cahoon, U.S. Geological Survey. 


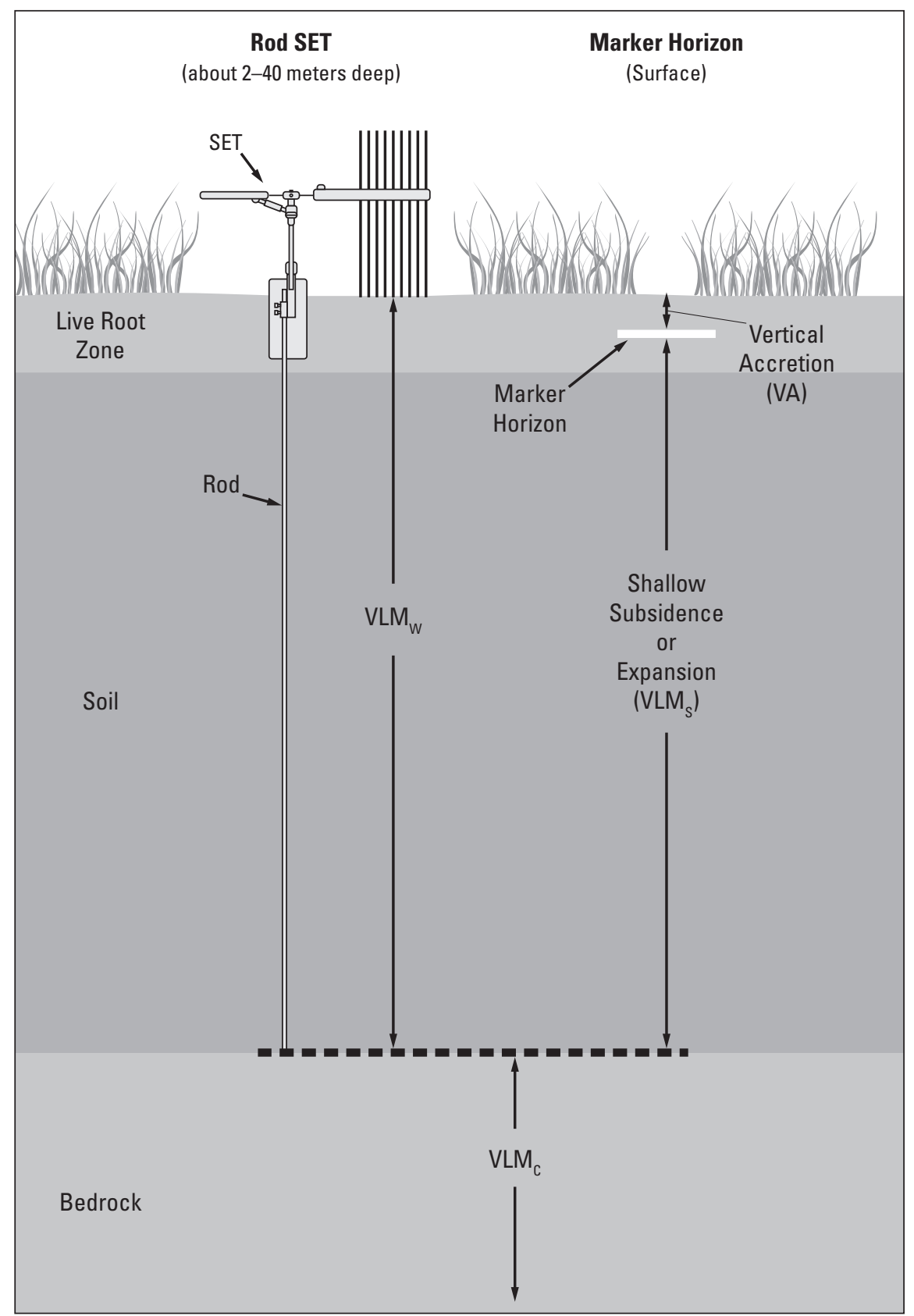

Figure 1.3. Diagram of a wetland substrate showing the vertical relation between the measurements of elevation change by the rod surface elevation table (RSET) (vertical land motion or $\mathrm{VLM}_{\mathrm{w}}$ ) and vertical accretion (VA) by the marker horizon. Shallow subsidence $\left(V_{L} M_{s}\right)$ or expansion $\left(V_{L} M_{e}\right)$ is calculated from a direct comparison of the two rates $\left(V A-V L M_{w}\right)$. Crustal vertical land motion $\left.(V L M)_{c}\right)$ is not measured by the SET-MH method. Figure from Cahoon, 2015. 


\section{Appendix 2. SET-MH Metadata Spreadsheet}

Table 2.1. Surface elevation table-marker horizon (SET-MH) data.

[ME, Maine; VA, Virginia; MA, Massachusetts; CT, Connecticut; NH, New Hampshire; NY, New York; RI, Rhode Island; NJ, New Jersey; DE, Delaware; MD, Maryland; NWR, National Wildlife Refuge; WMA, Wildlife Management Area; NS, National Seashore; LTER, Long Term Ecological Research site; PIE LTER, Plum Island Ecosystems; VCR LTER, Virginia Coast Reserve; NPS, National Park Service; USFWS, U.S. Fish and Wildlife Service; USGS, U.S. Geological Survey; NYC, New York City; TNC, The Nature Conservancy; MERI, Meadowlands Environmental Research Institute; FDU, Fairleigh Dickinson University; SERC; Smithsonian Environmental Research Center; NERR, National Estuarine Research Reserve; LIS, Long Island Sound]

\begin{tabular}{|c|c|c|c|c|c|}
\hline SET_Geographical_Location & Site & State & Sub_Region & Partner & Broad_Geomophic_Setting \\
\hline Acadia National Park, ME & Acadia.Bass.Harbor & ME & 1_Coastal_Maine & NPS & Estuarine Embayment \\
\hline Acadia National Park, ME & Acadia.Bass.Harbor & ME & 1_Coastal_Maine & NPS & Estuarine Embayment \\
\hline Acadia National Park, ME & Acadia.Bass.Harbor & ME & 1_Coastal_Maine & NPS & Estuarine Embayment \\
\hline Acadia National Park, ME & Acadia.Schoolic.Peninsula & ME & 1_Coastal_Maine & NPS & Estuarine Embayment \\
\hline Acadia National Park, ME & Acadia.Schoolic.Peninsula & ME & 1_Coastal_Maine & NPS & Estuarine Embayment \\
\hline Acadia National Park, ME & Acadia.Schoolic.Peninsula & ME & 1_Coastal_Maine & NPS & Estuarine Embayment \\
\hline Acadia National Park, ME & Acadia.Maine.Coast.Heritage & ME & 1_Coastal_Maine & NPS & Estuarine Embayment \\
\hline Acadia National Park, ME & Acadia.Maine.Coast.Heritage & ME & 1_Coastal_Maine & NPS & Estuarine Embayment \\
\hline Acadia National Park, ME & Acadia.Maine.Coast.Heritage & ME & 1_Coastal_Maine & NPS & Estuarine Embayment \\
\hline Acadia National Park, ME & Acadia.Thompson.Island & ME & 1_Coastal_Maine & NPS & Estuarine Embayment \\
\hline Acadia National Park, ME & Acadia.Thompson.Island & ME & 1_Coastal_Maine & NPS & Estuarine Embayment \\
\hline Acadia National Park, ME & Acadia.Thompson.Island & ME & 1_Coastal_Maine & NPS & Estuarine Embayment \\
\hline $\begin{array}{l}\text { PETIT MANAN NATIONAL WILDLIFE } \\
\text { REFUGE }\end{array}$ & Gouldsboro Marsh 3 & ME & 1_Coastal_Maine & USFWS & Estuarine Embayment \\
\hline $\begin{array}{l}\text { PETIT MANAN NATIONAL WILDLIFE } \\
\text { REFUGE }\end{array}$ & Gouldsboro Marsh 2 & ME & 1_Coastal_Maine & USFWS & Estuarine Embayment \\
\hline $\begin{array}{l}\text { PETIT MANAN NATIONAL WILDLIFE } \\
\text { REFUGE }\end{array}$ & Gouldsboro Marsh 1 & ME & 1_Coastal_Maine & USFWS & Estuarine Embayment \\
\hline
\end{tabular}


Table 2.1. Surface elevation table-marker horizon (SET-MH) data.-Continued

\begin{tabular}{|c|c|c|c|c|c|}
\hline SET_Geographical_Location & Site & State & Sub_Region & Partner & Broad_Geomophic_Setting \\
\hline $\begin{array}{l}\text { PETIT MANAN NATIONAL WILDLIFE } \\
\text { REFUGE }\end{array}$ & Sawyers Marsh 3 & ME & 1_Coastal_Maine & USFWS & Estuarine Embayment \\
\hline $\begin{array}{l}\text { PETIT MANAN NATIONAL WILDLIFE } \\
\text { REFUGE }\end{array}$ & Sawyers Marsh 2 & ME & 1_Coastal_Maine & USFWS & Estuarine Embayment \\
\hline $\begin{array}{l}\text { PETIT MANAN NATIONAL WILDLIFE } \\
\text { REFUGE }\end{array}$ & Sawyers Marsh 1 & ME & 1_Coastal_Maine & USFWS & Estuarine Embayment \\
\hline $\begin{array}{l}\text { MOOSEHORN NATIONAL WILDLIFE } \\
\text { REFUGE }\end{array}$ & Hallowell Island & ME & 1_Coastal_Maine & USFWS & Estuarine Embayment \\
\hline $\begin{array}{l}\text { MOOSEHORN NATIONAL WILDLIFE } \\
\text { REFUGE }\end{array}$ & Hallowell Island & ME & 1_Coastal_Maine & USFWS & Estuarine Embayment \\
\hline $\begin{array}{l}\text { MOOSEHORN NATIONAL WILDLIFE } \\
\text { REFUGE }\end{array}$ & Hallowell Island & ME & 1_Coastal_Maine & USFWS & Estuarine Embayment \\
\hline $\begin{array}{l}\text { MOOSEHORN NATIONAL WILDLIFE } \\
\text { REFUGE }\end{array}$ & Hobart St. West & ME & 1_Coastal_Maine & USFWS & Estuarine Embayment \\
\hline $\begin{array}{l}\text { MOOSEHORN NATIONAL WILDLIFE } \\
\text { REFUGE }\end{array}$ & Hobart St. West & ME & 1_Coastal_Maine & USFWS & Estuarine Embayment \\
\hline $\begin{array}{l}\text { MOOSEHORN NATIONAL WILDLIFE } \\
\text { REFUGE }\end{array}$ & Hobart St. West & ME & 1_Coastal_Maine & USFWS & Estuarine Embayment \\
\hline $\begin{array}{l}\text { MOOSEHORN NATIONAL WILDLIFE } \\
\text { REFUGE }\end{array}$ & Hobart St. East & ME & 1_Coastal_Maine & USFWS & Estuarine Embayment \\
\hline $\begin{array}{l}\text { MOOSEHORN NATIONAL WILDLIFE } \\
\text { REFUGE }\end{array}$ & Hobart St. East & ME & 1_Coastal_Maine & USFWS & Estuarine Embayment \\
\hline $\begin{array}{l}\text { MOOSEHORN NATIONAL WILDLIFE } \\
\text { REFUGE }\end{array}$ & Hobart St. East & ME & 1_Coastal_Maine & USFWS & Estuarine Embayment \\
\hline $\begin{array}{l}\text { MOOSEHORN NATIONAL WILDLIFE } \\
\text { REFUGE }\end{array}$ & Ox Cove Rd. Area & ME & 1_Coastal_Maine & USFWS & Estuarine Embayment \\
\hline $\begin{array}{l}\text { MOOSEHORN NATIONAL WILDLIFE } \\
\text { REFUGE }\end{array}$ & Ox Cove Rd. Area & ME & 1_Coastal_Maine & USFWS & Estuarine Embayment \\
\hline $\begin{array}{l}\text { MOOSEHORN NATIONAL WILDLIFE } \\
\text { REFUGE }\end{array}$ & Ox Cove Rd. Area & ME & 1_Coastal_Maine & USFWS & Estuarine Embayment \\
\hline $\begin{array}{l}\text { PETIT MANAN NATIONAL WILDLIFE } \\
\text { REFUGE }\end{array}$ & Sawyers Marsh 4 & ME & 1_Coastal_Maine & USFWS & Estuarine Embayment \\
\hline Back Bay NWR & Long.Island.South & VA & 10_Coastal_Virginia & USFWS & Non-tidal Brackish Marsh \\
\hline Back Bay NWR & Long.Island.South & VA & 10_Coastal_Virginia & USFWS & Non-tidal Brackish Marsh \\
\hline
\end{tabular}


Table 2.1. Surface elevation table-marker horizon (SET-MH) data.-Continued

\begin{tabular}{|c|c|c|c|c|c|}
\hline SET_Geographical_Location & Site & State & Sub_Region & Partner & Broad_Geomophic_Setting \\
\hline Back Bay NWR & Long.Island.South & VA & 10_Coastal_Virginia & USFWS & Non-tidal Brackish Marsh \\
\hline Back Bay NWR & Long.Island.North & VA & 10_Coastal_Virginia & USFWS & Non-tidal Brackish Marsh \\
\hline Back Bay NWR & Long.Island.North & VA & 10_Coastal_Virginia & USFWS & Non-tidal Brackish Marsh \\
\hline Back Bay NWR & Long.Island.North & VA & 10_Coastal_Virginia & USFWS & Non-tidal Brackish Marsh \\
\hline Back Bay NWR & North.Marsh & VA & 10_Coastal_Virginia & USFWS & Non-tidal Brackish Marsh \\
\hline Back Bay NWR & North.Marsh & VA & 10_Coastal_Virginia & USFWS & Non-tidal Brackish Marsh \\
\hline Back Bay NWR & North.Marsh & VA & 10_Coastal_Virginia & USFWS & Non-tidal Brackish Marsh \\
\hline Plum Island Ecosystems LTER & LTE-MP-LPP & MA & 2_CapeCod_CascoBay & $\begin{array}{c}\text { Marine Biological } \\
\text { Lab/PIE LTER }\end{array}$ & Back-barrier Lagoon Marsh \\
\hline Plum Island Ecosystems LTER & LTE-MP-LPA & MA & 2_CapeCod_CascoBay & $\begin{array}{c}\text { Marine Biological } \\
\text { Lab/PIE LTER }\end{array}$ & Back-barrier Lagoon Marsh \\
\hline Plum Island Ecosystems LTER & LTE-MP-LPA & MA & 2_CapeCod_CascoBay & $\begin{array}{c}\text { Marine Biological } \\
\text { Lab/PIE LTER }\end{array}$ & Back-barrier Lagoon Marsh \\
\hline Plum Island Ecosystems LTER & LTE-MP-LPA & MA & 2_CapeCod_CascoBay & $\begin{array}{c}\text { Marine Biological } \\
\text { Lab/PIE LTER }\end{array}$ & Back-barrier Lagoon Marsh \\
\hline Plum Island Ecosystems LTER & LTE-MP-LPP & MA & 2_CapeCod_CascoBay & $\begin{array}{c}\text { Marine Biological } \\
\text { Lab/PIE LTER }\end{array}$ & Back-barrier Lagoon Marsh \\
\hline Plum Island Ecosystems LTER & LTE-MP-LPP & MA & 2_CapeCod_CascoBay & $\begin{array}{c}\text { Marine Biological } \\
\text { Lab/PIE LTER }\end{array}$ & Back-barrier Lagoon Marsh \\
\hline Cape Cod NS, MA & Nauset.Marsh & MA & 2_CapeCod_CascoBay & NPS & Back-barrier Lagoon Marsh \\
\hline Cape Cod NS, MA & Nauset.Marsh & MA & 2_CapeCod_CascoBay & NPS & Back-barrier Lagoon Marsh \\
\hline Cape Cod NS, MA & Nauset.Marsh & MA & 2_CapeCod_CascoBay & NPS & Back-barrier Lagoon Marsh \\
\hline Cape Cod NS, MA & Nauset.Marsh & MA & 2_CapeCod_CascoBay & NPS & Back-barrier Lagoon Marsh \\
\hline Boston Harbor Island, MA & Boston.Harbor.Peddocks.Island & MA & 2_CapeCod_CascoBay & NPS & Back-barrier Lagoon Marsh \\
\hline
\end{tabular}


Table 2.1. Surface elevation table-marker horizon (SET-MH) data.-Continued

\begin{tabular}{|c|c|c|c|c|c|}
\hline SET_Geographical_Location & Site & State & Sub_Region & Partner & Broad_Geomophic_Setting \\
\hline Boston Harbor Island, MA & Boston.Harbor.Peddocks.Island & MA & 2_CapeCod_CascoBay & NPS & Back-barrier Lagoon Marsh \\
\hline Boston Harbor Island, MA & Boston.Harbor.Peddocks.Island & MA & 2_CapeCod_CascoBay & NPS & Back-barrier Lagoon Marsh \\
\hline Boston Harbor Island, MA & Boston.Harbor.Thompson.Island & MA & 2_CapeCod_CascoBay & NPS & Back-barrier Lagoon Marsh \\
\hline Boston Harbor Island, MA & Boston.Harbor.Thompson.Island & MA & 2_CapeCod_CascoBay & NPS & Back-barrier Lagoon Marsh \\
\hline Boston Harbor Island, MA & Boston.Harbor.Thompson.Island & MA & 2_CapeCod_CascoBay & NPS & Back-barrier Lagoon Marsh \\
\hline Boston Harbor Island, MA & Boston.Harbor.Thompson.Island & MA & 2_CapeCod_CascoBay & NPS & Back-barrier Lagoon Marsh \\
\hline Cape Cod NS, MA & Cape Cod NS, MA_N & MA & 2_CapeCod_CascoBay & NPS & Back-barrier Lagoon Marsh \\
\hline Cape Cod NS, MA & Cape Cod NS, MA_N & MA & 2_CapeCod_CascoBay & NPS & Back-barrier Lagoon Marsh \\
\hline Cape Cod NS, MA & Cape Cod NS, MA_N & MA & 2_CapeCod_CascoBay & NPS & Back-barrier Lagoon Marsh \\
\hline Cape Cod NS, MA & Cape Cod NS, MA_GUTSET & MA & 2_CapeCod_CascoBay & NPS & Back-barrier Lagoon Marsh \\
\hline Cape Cod NS, MA & Cape Cod NS, MA_GUTSET & MA & 2_CapeCod_CascoBay & NPS & Back-barrier Lagoon Marsh \\
\hline Cape Cod NS, MA & Cape Cod NS, MA_GUTSET & MA & 2_CapeCod_CascoBay & NPS & Back-barrier Lagoon Marsh \\
\hline Cape Cod NS, MA & Cape Cod NS, MA_PHRAGSET & MA & 2_CapeCod_CascoBay & NPS & Back-barrier Lagoon Marsh \\
\hline Cape Cod NS, MA & Cape Cod NS, MA_PHRAGSET & MA & 2_CapeCod_CascoBay & NPS & Back-barrier Lagoon Marsh \\
\hline Cape Cod NS, MA & Cape Cod NS, MA_PHRAGSET & MA & 2_CapeCod_CascoBay & NPS & Back-barrier Lagoon Marsh \\
\hline Cape Cod NS, MA & Cape Cod NS, MA_HTSET & MA & 2_CapeCod_CascoBay & NPS & Estuarine Brackish Marsh \\
\hline Cape Cod NS, MA & Cape Cod NS, MA_HTSET & MA & 2_CapeCod_CascoBay & NPS & Estuarine Brackish Marsh \\
\hline Cape Cod NS, MA & Cape Cod NS, MA_HTSET & MA & 2_CapeCod_CascoBay & NPS & Estuarine Brackish Marsh \\
\hline
\end{tabular}


Table 2.1. Surface elevation table-marker horizon (SET-MH) data.-Continued

\begin{tabular}{|c|c|c|c|c|c|}
\hline SET_Geographical_Location & Site & State & Sub_Region & Partner & Broad_Geomophic_Setting \\
\hline Cape Cod NS, MA & Cape Cod NS, MA_H & MA & 2_CapeCod_CascoBay & NPS & Back-barrier Lagoon Marsh \\
\hline Cape Cod NS, MA & Cape Cod NS, MA_HHSET & MA & 2_CapeCod_CascoBay & NPS & Back-barrier Lagoon Marsh \\
\hline Cape Cod NS, MA & Cape Cod NS, MA_H & MA & 2_CapeCod_CascoBay & NPS & Back-barrier Lagoon Marsh \\
\hline Cape Cod NS, MA & Cape Cod NS, MA_HHSET & MA & 2_CapeCod_CascoBay & NPS & Back-barrier Lagoon Marsh \\
\hline Cape Cod NS, MA & Cape Cod NS, MA_HHSET & MA & 2_CapeCod_CascoBay & NPS & Back-barrier Lagoon Marsh \\
\hline Cape Cod NS, MA & Cape Cod NS, MA_H & MA & 2_CapeCod_CascoBay & NPS & Back-barrier Lagoon Marsh \\
\hline Cape Cod NS, MA & Cape Cod NS, MA_HHSET & MA & 2_CapeCod_CascoBay & NPS & Back-barrier Lagoon Marsh \\
\hline Cape Cod NS, MA & Cape Cod NS, MA_HHSET & MA & 2_CapeCod_CascoBay & NPS & Back-barrier Lagoon Marsh \\
\hline Cape Cod NS, MA & Cape Cod NS, MA_HHSET & MA & 2_CapeCod_CascoBay & NPS & Back-barrier Lagoon Marsh \\
\hline Cape Cod NS, MA & Cape Cod NS, MA_HHSET & MA & 2_CapeCod_CascoBay & NPS & Back-barrier Lagoon Marsh \\
\hline Cape Cod NS, MA & Cape Cod NS, MA_HHSET & MA & 2_CapeCod_CascoBay & NPS & Back-barrier Lagoon Marsh \\
\hline Cape Cod NS, MA & Cape Cod NS, MA_HHSET & MA & 2_CapeCod_CascoBay & NPS & Back-barrier Lagoon Marsh \\
\hline Boston Harbor Island, MA & Boston.Harbor.Calf.Island & MA & 2_CapeCod_CascoBay & NPS & Open Coast \\
\hline Boston Harbor Island, MA & Boston.Harbor.Calf.Island & MA & 2_CapeCod_CascoBay & NPS & Open Coast \\
\hline Boston Harbor Island, MA & Boston.Harbor.Calf.Island & MA & 2_CapeCod_CascoBay & NPS & Open Coast \\
\hline Plum Island Estuary & MAR-RO-OldLevine-Set1 & MA & 2_CapeCod_CascoBay & PIE LTER & Back-barrier Lagoon Marsh \\
\hline Plum Island Estuary & MAR-RO-NewLevine-Set2 & MA & 2_CapeCod_CascoBay & PIE LTER & Back-barrier Lagoon Marsh \\
\hline Plum Island Estuary & MAR-RO-NewLevine-Set1 & MA & 2_CapeCod_CascoBay & PIE LTER & Back-barrier Lagoon Marsh \\
\hline
\end{tabular}


Table 2.1. Surface elevation table-marker horizon (SET-MH) data.-Continued

\begin{tabular}{|c|c|c|c|c|c|}
\hline SET_Geographical_Location & Site & State & Sub_Region & Partner & Broad_Geomophic_Setting \\
\hline Plum Island Estuary & MAR-RO-NewLevine-Set3 & MA & 2_CapeCod_CascoBay & PIE LTER & Back-barrier Lagoon Marsh \\
\hline Plum Island Estuary & MAR-RO-OldLevine-Set2 & MA & 2_CapeCod_CascoBay & PIE LTER & Back-barrier Lagoon Marsh \\
\hline Plum Island Estuary & MAR-RO-OldLevine-Set3 & MA & 2_CapeCod_CascoBay & PIE LTER & Back-barrier Lagoon Marsh \\
\hline Plum Island Estuary & MAR-RO-InfillPond-Set2 & MA & 2_CapeCod_CascoBay & PIE LTER & Back-barrier Lagoon Marsh \\
\hline Plum Island Estuary & MAR-RO-InfillPond-Set3 & MA & 2_CapeCod_CascoBay & PIE LTER & Back-barrier Lagoon Marsh \\
\hline Plum Island Estuary & MAR-RO-MorrisIsle-Set1 & MA & 2_CapeCod_CascoBay & PIE LTER & Back-barrier Lagoon Marsh \\
\hline Plum Island Estuary & MAR-RO-MorrisIsle-Set2 & MA & 2_CapeCod_CascoBay & PIE LTER & Back-barrier Lagoon Marsh \\
\hline Plum Island Estuary & MAR-RO-MorrisIsle-Set3 & MA & 2_CapeCod_CascoBay & PIE LTER & Back-barrier Lagoon Marsh \\
\hline Plum Island Estuary & MAR-RO-HolyIs-Set 3 & MA & 2_CapeCod_CascoBay & PIE LTER & Back-barrier Lagoon Marsh \\
\hline Plum Island Estuary & MAR-RO-HolyIs-Set 2 & MA & 2_CapeCod_CascoBay & PIE LTER & Back-barrier Lagoon Marsh \\
\hline Plum Island Estuary & MAR-RO-HolyIs-Set 1 & MA & 2_CapeCod_CascoBay & PIE LTER & Back-barrier Lagoon Marsh \\
\hline Plum Island Estuary & MAR-RO-LawsPt-Set2 & MA & 2_CapeCod_CascoBay & PIE LTER & Back-barrier Lagoon Marsh \\
\hline Plum Island Estuary & MAR-RO-LawsPt-Set1 & MA & 2_CapeCod_CascoBay & PIE LTER & Back-barrier Lagoon Marsh \\
\hline Hampton-Seabrook Estuary & Browns Seafood & NH & 2_CapeCod_CascoBay & Academic & Back-barrier Lagoon Marsh \\
\hline Hampton-Seabrook Estuary & Walton Road & $\mathrm{NH}$ & 2_CapeCod_CascoBay & Academic & Back-barrier Lagoon Marsh \\
\hline Hampton-Seabrook Estuary & Hampton & $\mathrm{NH}$ & 2_CapeCod_CascoBay & Academic & Back-barrier Lagoon Marsh \\
\hline Hampton-Seabrook Estuary & Hampton Falls & $\mathrm{NH}$ & 2_CapeCod_CascoBay & Academic & Back-barrier Lagoon Marsh \\
\hline Hampton-Seabrook Estuary & Route 101 & NH & 2_CapeCod_CascoBay & Academic & Back-barrier Lagoon Marsh \\
\hline
\end{tabular}


Table 2.1. Surface elevation table-marker horizon (SET-MH) data.-Continued

\begin{tabular}{|c|c|c|c|c|c|}
\hline SET_Geographical_Location & Site & State & Sub_Region & Partner & Broad_Geomophic_Setting \\
\hline Hampton-Seabrook Estuary & Route 1 & $\mathrm{NH}$ & 2_CapeCod_CascoBay & Academic & Back-barrier Lagoon Marsh \\
\hline Rye Harbor - Awcomin Marsh & Awcomin & $\mathrm{NH}$ & 2_CapeCod_CascoBay & Academic & Back-barrier Lagoon Marsh \\
\hline Rye Harbor - Awcomin Marsh & Awcomin & $\mathrm{NH}$ & 2_CapeCod_CascoBay & Academic & Back-barrier Lagoon Marsh \\
\hline Rye Harbor - Awcomin Marsh & Awcomin & $\mathrm{NH}$ & 2_CapeCod_CascoBay & Academic & Back-barrier Lagoon Marsh \\
\hline Rye Harbor - Awcomin Marsh & Awcomin & $\mathrm{NH}$ & 2_CapeCod_CascoBay & Academic & Back-barrier Lagoon Marsh \\
\hline Plum Island Estuary & Plum Island Estuary_Oak Knoll & MA & 2_CapeCod_CascoBay & Academic & Back-barrier Lagoon Marsh \\
\hline Plum Island Estuary & Plum Island Estuary_Oak Knoll & MA & 2_CapeCod_CascoBay & Academic & Back-barrier Lagoon Marsh \\
\hline Plum Island Estuary & Plum Island Estuary_Oak Knoll & MA & 2_CapeCod_CascoBay & Academic & Back-barrier Lagoon Marsh \\
\hline Plum Island Estuary & Plum Island Estuary_Oak Knoll & MA & 2_CapeCod_CascoBay & Academic & Back-barrier Lagoon Marsh \\
\hline Squamscott River & Squamscott River & $\mathrm{NH}$ & 2_CapeCod_CascoBay & Academic & Estuarine Brackish Marsh \\
\hline Great Bay NERR & Sandy Point NERR & $\mathrm{NH}$ & 2_CapeCod_CascoBay & Academic & Estuarine Embayment \\
\hline Great Bay NERR & Sandy Point NERR & $\mathrm{NH}$ & 2_CapeCod_CascoBay & Academic & Estuarine Embayment \\
\hline Great Bay NERR & Sandy Point NERR & $\mathrm{NH}$ & 2_CapeCod_CascoBay & Academic & Estuarine Embayment \\
\hline Great Bay NERR & Sandy Point NERR & $\mathrm{NH}$ & 2_CapeCod_CascoBay & Academic & Estuarine Embayment \\
\hline Great Bay Farms & Great Bay Farms & $\mathrm{NH}$ & 2_CapeCod_CascoBay & Academic & Estuarine Brackish Marsh \\
\hline Great Bay Farms & Great Bay Farms & $\mathrm{NH}$ & 2_CapeCod_CascoBay & Academic & Estuarine Brackish Marsh \\
\hline Great Bay Farms & Great Bay Farms & $\mathrm{NH}$ & 2_CapeCod_CascoBay & Academic & Estuarine Brackish Marsh \\
\hline Webhannet Marsh & Webhannet Marsh_Mile Rd & ME & 2_CapeCod_CascoBay & Academic & Back-barrier Lagoon Marsh \\
\hline
\end{tabular}


Table 2.1. Surface elevation table-marker horizon (SET-MH) data.-Continued

\begin{tabular}{|c|c|c|c|c|c|}
\hline SET_Geographical_Location & Site & State & Sub_Region & Partner & Broad_Geomophic_Setting \\
\hline Webhannet Marsh & Webhannet Marsh_Mile Rd & ME & 2_CapeCod_CascoBay & Academic & Back-barrier Lagoon Marsh \\
\hline Webhannet Marsh & Webhannet Marsh_Oxcart Lane & ME & 2_CapeCod_CascoBay & Academic & Back-barrier Lagoon Marsh \\
\hline Webhannet Marsh & Webhannet Marsh_Harbor Rd & ME & 2_CapeCod_CascoBay & Academic & Back-barrier Lagoon Marsh \\
\hline Webhannet Marsh & Webhannet Marsh_Harbor Rd & $\mathrm{ME}$ & 2_CapeCod_CascoBay & Academic & Back-barrier Lagoon Marsh \\
\hline Webhannet Marsh & Webhannet Marsh_Harbor Rd & $\mathrm{ME}$ & 2_CapeCod_CascoBay & Academic & Back-barrier Lagoon Marsh \\
\hline Webhannet Marsh & Webhannet Marsh_Harbor Rd & $\mathrm{ME}$ & 2_CapeCod_CascoBay & Academic & Back-barrier Lagoon Marsh \\
\hline Webhannet Marsh & Webhannet Marsh_DIM & ME & 2_CapeCod_CascoBay & Academic & Back-barrier Lagoon Marsh \\
\hline Webhannet Marsh & Webhannet Marsh_DIM & ME & 2_CapeCod_CascoBay & Academic & Back-barrier Lagoon Marsh \\
\hline Webhannet Marsh & Webhannet Marsh_DIM & ME & 2_CapeCod_CascoBay & Academic & Back-barrier Lagoon Marsh \\
\hline Rachel Carson NWR & Rachel Carson NWR_Moody Marsh & ME & 2_CapeCod_CascoBay & USFWS & Back-barrier Lagoon Marsh \\
\hline Rachel Carson NWR & Rachel Carson NWR_Moody Marsh & ME & 2_CapeCod_CascoBay & USFWS & Back-barrier Lagoon Marsh \\
\hline Rachel Carson NWR & Rachel Carson NWR_Granite Point Marsh & $\mathrm{ME}$ & 2_CapeCod_CascoBay & USFWS & Back-barrier Lagoon Marsh \\
\hline Rachel Carson NWR & Rachel Carson NWR_Granite Point Marsh & ME & 2_CapeCod_CascoBay & USFWS & Back-barrier Lagoon Marsh \\
\hline Rachel Carson NWR & Rachel Carson NWR_Granite Point Marsh & ME & 2_CapeCod_CascoBay & USFWS & Back-barrier Lagoon Marsh \\
\hline $\begin{array}{l}\text { MOMOMOY NATIONAL WILDLIFE } \\
\text { REFUGE }\end{array}$ & North Monomoy 03 & MA & 2_CapeCod_CascoBay & USFWS & Back-barrier Lagoon Marsh \\
\hline $\begin{array}{l}\text { MOMOMOY NATIONAL WILDLIFE } \\
\text { REFUGE }\end{array}$ & North Monomoy 02 & MA & 2_CapeCod_CascoBay & USFWS & Back-barrier Lagoon Marsh \\
\hline $\begin{array}{l}\text { MOMOMOY NATIONAL WILDLIFE } \\
\text { REFUGE }\end{array}$ & North Monomoy 01 & MA & 2_CapeCod_CascoBay & USFWS & Back-barrier Lagoon Marsh \\
\hline $\begin{array}{l}\text { MOMOMOY NATIONAL WILDLIFE } \\
\text { REFUGE }\end{array}$ & Morris 01 & MA & 2_CapeCod_CascoBay & USFWS & Back-barrier Lagoon Marsh \\
\hline
\end{tabular}


Table 2.1. Surface elevation table-marker horizon (SET-MH) data.-Continued

\begin{tabular}{|c|c|c|c|c|c|}
\hline SET_Geographical_Location & Site & State & Sub_Region & Partner & Broad_Geomophic_Setting \\
\hline $\begin{array}{l}\text { PARKER RIVER NATIONAL WILDLIFE } \\
\text { REFUGE }\end{array}$ & Cross Farm 02 & MA & 2_CapeCod_CascoBay & USFWS & Back-barrier Lagoon Marsh \\
\hline $\begin{array}{l}\text { PARKER RIVER NATIONAL WILDLIFE } \\
\text { REFUGE }\end{array}$ & Cross Farm 03 & MA & 2_CapeCod_CascoBay & USFWS & Back-barrier Lagoon Marsh \\
\hline $\begin{array}{l}\text { PARKER RIVER NATIONAL WILDLIFE } \\
\text { REFUGE }\end{array}$ & Cross Farm 01 & MA & 2_CapeCod_CascoBay & USFWS & Back-barrier Lagoon Marsh \\
\hline $\begin{array}{l}\text { PARKER RIVER NATIONAL WILDLIFE } \\
\text { REFUGE }\end{array}$ & Grape_Clam_01 & MA & 2_CapeCod_CascoBay & USFWS & Back-barrier Lagoon Marsh \\
\hline $\begin{array}{l}\text { PARKER RIVER NATIONAL WILDLIFE } \\
\text { REFUGE }\end{array}$ & Clam Flats 02 & MA & 2_CapeCod_CascoBay & USFWS & Back-barrier Lagoon Marsh \\
\hline $\begin{array}{l}\text { PARKER RIVER NATIONAL WILDLIFE } \\
\text { REFUGE }\end{array}$ & Clam Flats 01 & MA & 2_CapeCod_CascoBay & USFWS & Back-barrier Lagoon Marsh \\
\hline $\begin{array}{l}\text { PARKER RIVER NATIONAL WILDLIFE } \\
\text { REFUGE }\end{array}$ & Grape 02 & MA & 2_CapeCod_CascoBay & USFWS & Back-barrier Lagoon Marsh \\
\hline $\begin{array}{l}\text { PARKER RIVER NATIONAL WILDLIFE } \\
\text { REFUGE }\end{array}$ & Knobb 03 & MA & 2_CapeCod_CascoBay & USFWS & Back-barrier Lagoon Marsh \\
\hline $\begin{array}{l}\text { PARKER RIVER NATIONAL WILDLIFE } \\
\text { REFUGE }\end{array}$ & Knobb 02 & MA & 2_CapeCod_CascoBay & USFWS & Back-barrier Lagoon Marsh \\
\hline $\begin{array}{l}\text { PARKER RIVER NATIONAL WILDLIFE } \\
\text { REFUGE }\end{array}$ & Knobb 01 & MA & 2_CapeCod_CascoBay & USFWS & Back-barrier Lagoon Marsh \\
\hline $\begin{array}{l}\text { PARKER RIVER NATIONAL WILDLIFE } \\
\text { REFUGE }\end{array}$ & Bill_Forward_2014 & MA & 2_CapeCod_CascoBay & USFWS & Back-barrier Lagoon Marsh \\
\hline $\begin{array}{l}\text { PARKER RIVER NATIONAL WILDLIFE } \\
\text { REFUGE }\end{array}$ & Npool_Impoun 03 & MA & 2_CapeCod_CascoBay & USFWS & Back-barrier Lagoon Marsh \\
\hline $\begin{array}{l}\text { PARKER RIVER NATIONAL WILDLIFE } \\
\text { REFUGE }\end{array}$ & Nelson 02 & MA & 2_CapeCod_CascoBay & USFWS & Back-barrier Lagoon Marsh \\
\hline $\begin{array}{l}\text { PARKER RIVER NATIONAL WILDLIFE } \\
\text { REFUGE }\end{array}$ & Nelson 01 & MA & 2_CapeCod_CascoBay & USFWS & Back-barrier Lagoon Marsh \\
\hline $\begin{array}{l}\text { PARKER RIVER NATIONAL WILDLIFE } \\
\text { REFUGE }\end{array}$ & NP02 & MA & 2_CapeCod_CascoBay & USFWS & Back-barrier Lagoon Marsh \\
\hline $\begin{array}{l}\text { PARKER RIVER NATIONAL WILDLIFE } \\
\text { REFUGE }\end{array}$ & NP03 & MA & 2_CapeCod_CascoBay & USFWS & Back-barrier Lagoon Marsh \\
\hline $\begin{array}{l}\text { PARKER RIVER NATIONAL WILDLIFE } \\
\text { REFUGE }\end{array}$ & Nelson 03 & MA & 2_CapeCod_CascoBay & USFWS & Back-barrier Lagoon Marsh \\
\hline $\begin{array}{l}\text { PARKER RIVER NATIONAL WILDLIFE } \\
\text { REFUGE }\end{array}$ & Npool_Impoun 02 & MA & 2_CapeCod_CascoBay & USFWS & Back-barrier Lagoon Marsh \\
\hline
\end{tabular}


Table 2.1. Surface elevation table-marker horizon (SET-MH) data.-Continued

\begin{tabular}{|c|c|c|c|c|c|}
\hline SET_Geographical_Location & Site & State & Sub_Region & Partner & Broad_Geomophic_Setting \\
\hline $\begin{array}{l}\text { PARKER RIVER NATIONAL WILDLIFE } \\
\text { REFUGE }\end{array}$ & Npool_Impoun 01 & MA & 2_CapeCod_CascoBay & USFWS & Back-barrier Lagoon Marsh \\
\hline $\begin{array}{l}\text { PARKER RIVER NATIONAL WILDLIFE } \\
\text { REFUGE }\end{array}$ & NP01 & MA & 2_CapeCod_CascoBay & USFWS & Back-barrier Lagoon Marsh \\
\hline $\begin{array}{l}\text { PARKER RIVER NATIONAL WILDLIFE } \\
\text { REFUGE }\end{array}$ & Area_B 03 & MA & 2_CapeCod_CascoBay & USFWS & Back-barrier Lagoon Marsh \\
\hline $\begin{array}{l}\text { PARKER RIVER NATIONAL WILDLIFE } \\
\text { REFUGE }\end{array}$ & Area_B 01 & MA & 2_CapeCod_CascoBay & USFWS & Back-barrier Lagoon Marsh \\
\hline $\begin{array}{l}\text { PARKER RIVER NATIONAL WILDLIFE } \\
\text { REFUGE }\end{array}$ & Area_B 02 & MA & 2_CapeCod_CascoBay & USFWS & Back-barrier Lagoon Marsh \\
\hline $\begin{array}{l}\text { PARKER RIVER NATIONAL WILDLIFE } \\
\text { REFUGE }\end{array}$ & AAS01 & MA & 2_CapeCod_CascoBay & USFWS & Back-barrier Lagoon Marsh \\
\hline $\begin{array}{l}\text { PARKER RIVER NATIONAL WILDLIFE } \\
\text { REFUGE }\end{array}$ & After_02 & MA & 2_CapeCod_CascoBay & USFWS & Back-barrier Lagoon Marsh \\
\hline $\begin{array}{l}\text { PARKER RIVER NATIONAL WILDLIFE } \\
\text { REFUGE }\end{array}$ & After_01 & MA & 2_CapeCod_CascoBay & USFWS & Back-barrier Lagoon Marsh \\
\hline $\begin{array}{l}\text { PARKER RIVER NATIONAL WILDLIFE } \\
\text { REFUGE }\end{array}$ & AAS03 & MA & 2_CapeCod_CascoBay & USFWS & Back-barrier Lagoon Marsh \\
\hline $\begin{array}{l}\text { PARKER RIVER NATIONAL WILDLIFE } \\
\text { REFUGE }\end{array}$ & After_03 & MA & 2_CapeCod_CascoBay & USFWS & Back-barrier Lagoon Marsh \\
\hline $\begin{array}{l}\text { PARKER RIVER NATIONAL WILDLIFE } \\
\text { REFUGE }\end{array}$ & AAS02 & MA & 2_CapeCod_CascoBay & USFWS & Back-barrier Lagoon Marsh \\
\hline $\begin{array}{l}\text { PARKER RIVER NATIONAL WILDLIFE } \\
\text { REFUGE }\end{array}$ & SP02 & MA & 2_CapeCod_CascoBay & USFWS & Back-barrier Lagoon Marsh \\
\hline $\begin{array}{l}\text { PARKER RIVER NATIONAL WILDLIFE } \\
\text { REFUGE }\end{array}$ & SP01 & MA & 2_CapeCod_CascoBay & USFWS & Back-barrier Lagoon Marsh \\
\hline $\begin{array}{l}\text { PARKER RIVER NATIONAL WILDLIFE } \\
\text { REFUGE }\end{array}$ & AAN 01 & MA & 2_CapeCod_CascoBay & USFWS & Back-barrier Lagoon Marsh \\
\hline $\begin{array}{l}\text { PARKER RIVER NATIONAL WILDLIFE } \\
\text { REFUGE }\end{array}$ & SP03 & MA & 2_CapeCod_CascoBay & USFWS & Back-barrier Lagoon Marsh \\
\hline $\begin{array}{l}\text { PARKER RIVER NATIONAL WILDLIFE } \\
\text { REFUGE }\end{array}$ & ANN 02 & MA & 2_CapeCod_CascoBay & USFWS & Back-barrier Lagoon Marsh \\
\hline $\begin{array}{l}\text { PARKER RIVER NATIONAL WILDLIFE } \\
\text { REFUGE }\end{array}$ & B2 5-40 & MA & 2_CapeCod_CascoBay & USFWS & Back-barrier Lagoon Marsh \\
\hline $\begin{array}{l}\text { PARKER RIVER NATIONAL WILDLIFE } \\
\text { REFUGE }\end{array}$ & B2 4-120 & MA & 2_CapeCod_CascoBay & USFWS & Back-barrier Lagoon Marsh \\
\hline
\end{tabular}


Table 2.1. Surface elevation table-marker horizon (SET-MH) data.-Continued

\begin{tabular}{|c|c|c|c|c|c|}
\hline SET_Geographical_Location & Site & State & Sub_Region & Partner & Broad_Geomophic_Setting \\
\hline $\begin{array}{l}\text { PARKER RIVER NATIONAL WILDLIFE } \\
\text { REFUGE }\end{array}$ & B2 1-80 & MA & 2_CapeCod_CascoBay & USFWS & Back-barrier Lagoon Marsh \\
\hline $\begin{array}{l}\text { PARKER RIVER NATIONAL WILDLIFE } \\
\text { REFUGE }\end{array}$ & Control 4-120 & MA & 2_CapeCod_CascoBay & USFWS & Back-barrier Lagoon Marsh \\
\hline $\begin{array}{l}\text { PARKER RIVER NATIONAL WILDLIFE } \\
\text { REFUGE }\end{array}$ & Control 3-120 & MA & 2_CapeCod_CascoBay & USFWS & Back-barrier Lagoon Marsh \\
\hline $\begin{array}{l}\text { PARKER RIVER NATIONAL WILDLIFE } \\
\text { REFUGE }\end{array}$ & Control 3-40 & MA & 2_CapeCod_CascoBay & USFWS & Back-barrier Lagoon Marsh \\
\hline $\begin{array}{l}\text { PARKER RIVER NATIONAL WILDLIFE } \\
\text { REFUGE }\end{array}$ & ANN 03 & MA & 2_CapeCod_CascoBay & USFWS & Back-barrier Lagoon Marsh \\
\hline Rachel Carson NWR & Moody Marsh & ME & 2_CapeCod_CascoBay & USFWS & Back-barrier Lagoon Marsh \\
\hline Rachel Carson NWR & Moody Marsh & ME & 2_CapeCod_CascoBay & USFWS & Back-barrier Lagoon Marsh \\
\hline Rachel Carson NWR & Moody Marsh & ME & 2_CapeCod_CascoBay & USFWS & Back-barrier Lagoon Marsh \\
\hline Rachel Carson NWR & Moody Marsh & ME & 2_CapeCod_CascoBay & USFWS & Back-barrier Lagoon Marsh \\
\hline Rachel Carson NWR & Moody Marsh & ME & 2_CapeCod_CascoBay & USFWS & Back-barrier Lagoon Marsh \\
\hline Rachel Carson NWR & Moody Marsh & ME & 2_CapeCod_CascoBay & USFWS & Back-barrier Lagoon Marsh \\
\hline Rachel Carson NWR & Bourne 3 & ME & 2_CapeCod_CascoBay & USFWS & Back-barrier Lagoon Marsh \\
\hline Rachel Carson NWR & Bourne 2 & ME & 2_CapeCod_CascoBay & USFWS & Back-barrier Lagoon Marsh \\
\hline Rachel Carson NWR & Bourne 1 & $\mathrm{ME}$ & 2_CapeCod_CascoBay & USFWS & Back-barrier Lagoon Marsh \\
\hline Rachel Carson NWR & Furbish 3 & ME & 2_CapeCod_CascoBay & USFWS & Back-barrier Lagoon Marsh \\
\hline Rachel Carson NWR & Furbish 2 & ME & 2_CapeCod_CascoBay & USFWS & Back-barrier Lagoon Marsh \\
\hline Rachel Carson NWR & Furbish 1 & $\mathrm{ME}$ & 2_CapeCod_CascoBay & USFWS & Back-barrier Lagoon Marsh \\
\hline Webhannet Marsh & Mile South 3 & $\mathrm{ME}$ & 2_CapeCod_CascoBay & USFWS & Back-barrier Lagoon Marsh \\
\hline
\end{tabular}


Table 2.1. Surface elevation table-marker horizon (SET-MH) data.-Continued

\begin{tabular}{|c|c|c|c|c|c|}
\hline SET_Geographical_Location & Site & State & Sub_Region & Partner & Broad_Geomophic_Setting \\
\hline Webhannet Marsh & Mile South 2 & ME & 2_CapeCod_CascoBay & USFWS & Back-barrier Lagoon Marsh \\
\hline Webhannet Marsh & Mile South 1 & ME & 2_CapeCod_CascoBay & USFWS & Back-barrier Lagoon Marsh \\
\hline Webhannet Marsh & Mile North 3 & ME & 2_CapeCod_CascoBay & USFWS & Back-barrier Lagoon Marsh \\
\hline Webhannet Marsh & Mile North 2 & ME & 2_CapeCod_CascoBay & USFWS & Back-barrier Lagoon Marsh \\
\hline $\begin{array}{l}\text { RACHEL CARSON NATIONAL } \\
\text { WILDLIFE REFUGE }\end{array}$ & Harbor 02 & ME & 2_CapeCod_CascoBay & USFWS & Back-barrier Lagoon Marsh \\
\hline $\begin{array}{l}\text { RACHEL CARSON NATIONAL } \\
\text { WILDLIFE REFUGE }\end{array}$ & Drakes 03 & $\mathrm{ME}$ & 2_CapeCod_CascoBay & USFWS & Back-barrier Lagoon Marsh \\
\hline $\begin{array}{l}\text { RACHEL CARSON NATIONAL } \\
\text { WILDLIFE REFUGE }\end{array}$ & Drakes 02 & ME & 2_CapeCod_CascoBay & USFWS & Back-barrier Lagoon Marsh \\
\hline $\begin{array}{l}\text { RACHEL CARSON NATIONAL } \\
\text { WILDLIFE REFUGE }\end{array}$ & Little River 2 & $\mathrm{ME}$ & 2_CapeCod_CascoBay & USFWS & Back-barrier Lagoon Marsh \\
\hline $\begin{array}{l}\text { RACHEL CARSON NATIONAL } \\
\text { WILDLIFE REFUGE }\end{array}$ & Little River 1 & ME & 2_CapeCod_CascoBay & USFWS & Back-barrier Lagoon Marsh \\
\hline $\begin{array}{l}\text { RACHEL CARSON NATIONAL } \\
\text { WILDLIFE REFUGE }\end{array}$ & Little River 3 & ME & 2_CapeCod_CascoBay & USFWS & Back-barrier Lagoon Marsh \\
\hline Rachel Carson NWR & Mousam Seaward 10 & ME & 2_CapeCod_CascoBay & USFWS & Estuarine Embayment \\
\hline Rachel Carson NWR & Mousam Seaward 9 & ME & 2_CapeCod_CascoBay & USFWS & Estuarine Embayment \\
\hline Rachel Carson NWR & Mousam Seaward 3 & $\mathrm{ME}$ & 2_CapeCod_CascoBay & USFWS & Estuarine Embayment \\
\hline Rachel Carson NWR & Mousam River 5 & ME & 2_CapeCod_CascoBay & USFWS & Estuarine Embayment \\
\hline Rachel Carson NWR & Mousam River 7 & ME & 2_CapeCod_CascoBay & USFWS & Estuarine Embayment \\
\hline Rachel Carson NWR & Mousam River 6 & ME & 2_CapeCod_CascoBay & USFWS & Estuarine Embayment \\
\hline Rachel Carson NWR & Granite Point Marsh & ME & 2_CapeCod_CascoBay & USFWS & Back-barrier Lagoon Marsh \\
\hline Rachel Carson NWR & Granite Point Marsh & ME & 2_CapeCod_CascoBay & USFWS & Back-barrier Lagoon Marsh \\
\hline
\end{tabular}


Table 2.1. Surface elevation table-marker horizon (SET-MH) data.-Continued

\begin{tabular}{|c|c|c|c|c|c|}
\hline SET_Geographical_Location & Site & State & Sub_Region & Partner & Broad_Geomophic_Setting \\
\hline Rachel Carson NWR & Granite Point EU 2 new & ME & 2_CapeCod_CascoBay & USFWS & Back-barrier Lagoon Marsh \\
\hline Rachel Carson NWR & Granite Point Marsh & ME & 2_CapeCod_CascoBay & USFWS & Back-barrier Lagoon Marsh \\
\hline Rachel Carson NWR & Granite Point Marsh & ME & 2_CapeCod_CascoBay & USFWS & Back-barrier Lagoon Marsh \\
\hline Rachel Carson NWR & Granite Point Marsh & ME & 2_CapeCod_CascoBay & USFWS & Back-barrier Lagoon Marsh \\
\hline Rachel Carson NWR & Goosefare Restrict 4 & ME & 2_CapeCod_CascoBay & USFWS & Estuarine Embayment \\
\hline Rachel Carson NWR & Goosefare Restrict 3 & ME & 2_CapeCod_CascoBay & USFWS & Estuarine Embayment \\
\hline Rachel Carson NWR & Goosefare Restrict 1 & ME & 2_CapeCod_CascoBay & USFWS & Estuarine Embayment \\
\hline Rachel Carson NWR & Goosefare 2 & ME & 2_CapeCod_CascoBay & USFWS & Estuarine Embayment \\
\hline Rachel Carson NWR & Goosefare 3 & ME & 2_CapeCod_CascoBay & USFWS & Estuarine Embayment \\
\hline Rachel Carson NWR & Goosefare 1 & ME & 2_CapeCod_CascoBay & USFWS & Estuarine Embayment \\
\hline Rachel Carson NWR & Rachel.Carson & ME & 2_CapeCod_CascoBay & USGS & Back-barrier Lagoon Marsh \\
\hline Rachel Carson NWR & Rachel.Carson & $\mathrm{ME}$ & 2_CapeCod_CascoBay & USGS & Back-barrier Lagoon Marsh \\
\hline Rachel Carson NWR & Rachel.Carson & $\mathrm{ME}$ & 2_CapeCod_CascoBay & USGS & Back-barrier Lagoon Marsh \\
\hline Rachel Carson NWR & Rachel.Carson & ME & 2_CapeCod_CascoBay & USGS & Back-barrier Lagoon Marsh \\
\hline Wells NERR, Maine & WR8 & ME & 2_CapeCod_CascoBay & NERR & Back-barrier Lagoon Marsh \\
\hline Wells NERR, Maine & LR21 & $\mathrm{ME}$ & 2_CapeCod_CascoBay & NERR & Back-barrier Lagoon Marsh \\
\hline Mamacoke Marsh & Mamacoke Marsh_Waterford & CT & 3_Southern_New_England & Academic & Estuarine Embayment \\
\hline Mamacoke Marsh & Mamacoke Marsh_Waterford & CT & 3_Southern_New_England & Academic & Estuarine Embayment \\
\hline
\end{tabular}


Table 2.1. Surface elevation table-marker horizon (SET-MH) data.-Continued

\begin{tabular}{|c|c|c|c|c|c|}
\hline SET_Geographical_Location & Site & State & Sub_Region & Partner & Broad_Geomophic_Setting \\
\hline Mamacoke Marsh & Mamacoke Marsh_Waterford & $\mathrm{CT}$ & 3_Southern_New_England & Academic & Estuarine Embayment \\
\hline Barn Island & Barn Island_Stonington & $\mathrm{CT}$ & 3_Southern_New_England & Academic & Estuarine Embayment \\
\hline Barn Island & Barn Island_Stonington & $\mathrm{CT}$ & 3_Southern_New_England & Academic & Estuarine Embayment \\
\hline Barn Island & Barn Island_Stonington & $\mathrm{CT}$ & 3_Southern_New_England & Academic & Estuarine Embayment \\
\hline Barn Island & Barn Island_Stonington & $\mathrm{CT}$ & 3_Southern_New_England & Academic & Estuarine Embayment \\
\hline Barn Island & Barn Island_Stonington & $\mathrm{CT}$ & 3_Southern_New_England & Academic & Estuarine Embayment \\
\hline Barn Island & Barn Island_Stonington & $\mathrm{CT}$ & 3_Southern_New_England & Academic & Estuarine Embayment \\
\hline Barn Island & Barn Island_Stonington & $\mathrm{CT}$ & 3_Southern_New_England & Academic & Estuarine Embayment \\
\hline Barn Island & Barn Island_Stonington & $\mathrm{CT}$ & 3_Southern_New_England & Academic & Estuarine Embayment \\
\hline Barn Island & Barn Island_Stonington & $\mathrm{CT}$ & 3_Southern_New_England & Academic & Estuarine Embayment \\
\hline $\begin{array}{l}\text { Pelham Bay Park A series (LIS side of Park), } \\
\text { Bronx, NY }\end{array}$ & $\begin{array}{l}\text { Pelham Bay Park A series (LIS side of } \\
\text { Park)_PB }\end{array}$ & NY & 3_Southern_New_England & NYC & Estuarine Embayment \\
\hline $\begin{array}{l}\text { Pelham Bay Park A series (LIS side of Park), } \\
\text { Bronx, NY }\end{array}$ & $\begin{array}{l}\text { Pelham Bay Park A series (LIS side of } \\
\text { Park)_PB }\end{array}$ & NY & 3_Southern_New_England & NYC & Estuarine Embayment \\
\hline $\begin{array}{l}\text { Pelham Bay Park A series (LIS side of Park), } \\
\text { Bronx, NY }\end{array}$ & $\begin{array}{l}\text { Pelham Bay Park A series (LIS side of } \\
\text { Park)_PB }\end{array}$ & NY & 3_Southern_New_England & NYC & Estuarine Embayment \\
\hline $\begin{array}{l}\text { Pelham Bay Park B series (Hutchinson River } \\
\text { side of Park), Bronx, NY }\end{array}$ & $\begin{array}{l}\text { Pelham Bay Park B series (Hutchinson } \\
\text { River side of Park)_PB }\end{array}$ & NY & 3_Southern_New_England & NYC & Estuarine Embayment \\
\hline $\begin{array}{l}\text { Pelham Bay Park B series (Hutchinson River } \\
\text { side of Park), Bronx, NY }\end{array}$ & $\begin{array}{l}\text { Pelham Bay Park B series (Hutchinson } \\
\text { River side of Park)_PB }\end{array}$ & NY & 3_Southern_New_England & NYC & Estuarine Embayment \\
\hline $\begin{array}{l}\text { Pelham Bay Park B series (Hutchinson River } \\
\text { side of Park), Bronx, NY }\end{array}$ & $\begin{array}{l}\text { Pelham Bay Park B series (Hutchinson } \\
\text { River side of Park)_PB }\end{array}$ & NY & 3_Southern_New_England & NYC & Estuarine Embayment \\
\hline Narragansett Bay NERR, Prudence Island RI & Nag & RI & 3_Southern_New_England & NERR & Estuarine Embayment \\
\hline Narragansett Bay NERR, Prudence Island RI & Nag & RI & 3_Southern_New_England & NERR & Estuarine Embayment \\
\hline
\end{tabular}


Table 2.1. Surface elevation table-marker horizon (SET-MH) data.-Continued

\begin{tabular}{|c|c|c|c|c|c|}
\hline SET_Geographical_Location & Site & State & Sub_Region & Partner & Broad_Geomophic_Setting \\
\hline Narragansett Bay NERR, Prudence Island RI & Nag & RI & 3_Southern_New_England & NERR & Estuarine Embayment \\
\hline Narragansett Bay NERR, Prudence Island RI & Nag & RI & 3_Southern_New_England & NERR & Estuarine Embayment \\
\hline Narragansett Bay NERR, Prudence Island RI & Nag & RI & 3_Southern_New_England & NERR & Estuarine Embayment \\
\hline Narragansett Bay NERR, Prudence Island RI & Nag & RI & 3_Southern_New_England & NERR & Estuarine Embayment \\
\hline Narragansett Bay NERR, Prudence Island RI & Coggeshall & RI & 3_Southern_New_England & NERR & Estuarine Embayment \\
\hline Narragansett Bay NERR, Prudence Island RI & Coggeshall & RI & 3_Southern_New_England & NERR & Estuarine Embayment \\
\hline Narragansett Bay NERR, Prudence Island RI & Coggeshall & RI & 3_Southern_New_England & NERR & Estuarine Embayment \\
\hline Narragansett Bay NERR, Prudence Island RI & Coggeshall & RI & 3_Southern_New_England & NERR & Estuarine Embayment \\
\hline Narragansett Bay NERR, Prudence Island RI & Coggeshall & RI & 3_Southern_New_England & NERR & Estuarine Embayment \\
\hline Narragansett Bay NERR, Prudence Island RI & Coggeshall & RI & 3_Southern_New_England & NERR & Estuarine Embayment \\
\hline Sachuest NWR, Middletown RI & Sachuest Point & RI & 3_Southern_New_England & Other & Back-barrier Lagoon Marsh \\
\hline Sachuest NWR, Middletown RI & Sachuest Point & RI & 3_Southern_New_England & Other & Back-barrier Lagoon Marsh \\
\hline Sachuest NWR, Middletown RI & Sachuest Point & RI & 3_Southern_New_England & Other & Back-barrier Lagoon Marsh \\
\hline Gooseneck Cove, Newport RI & Gooseneck Cove & RI & 3_Southern_New_England & Other & Estuarine Embayment \\
\hline Gooseneck Cove, Newport RI & Gooseneck Cove & RI & 3_Southern_New_England & Other & Estuarine Embayment \\
\hline Gooseneck Cove, Newport RI & Gooseneck Cove & RI & 3_Southern_New_England & Other & Estuarine Embayment \\
\hline $\begin{array}{l}\text { Long Island Sound - Sherwood Island State } \\
\text { Park }\end{array}$ & Sherwood & $\mathrm{CT}$ & 3_Southern_New_England & Academic & Estuarine Embayment \\
\hline $\begin{array}{l}\text { Long Island Sound - Sherwood Island State } \\
\text { Park }\end{array}$ & Sherwood & $\mathrm{CT}$ & 3_Southern_New_England & Academic & Estuarine Embayment \\
\hline
\end{tabular}


Table 2.1. Surface elevation table-marker horizon (SET-MH) data.-Continued

\begin{tabular}{|c|c|c|c|c|c|}
\hline SET_Geographical_Location & Site & State & Sub_Region & Partner & Broad_Geomophic_Setting \\
\hline $\begin{array}{l}\text { Long Island Sound - Sherwood Island State } \\
\text { Park }\end{array}$ & Sherwood & $\mathrm{CT}$ & 3_Southern_New_England & Academic & Estuarine Embayment \\
\hline Long Island Sound - Hoadley Creek & Hoadley & $\mathrm{CT}$ & 3_Southern_New_England & Academic & Estuarine Embayment \\
\hline Long Island Sound - Hoadley Creek & Hoadley & $\mathrm{CT}$ & 3_Southern_New_England & Academic & Estuarine Embayment \\
\hline Long Island Sound - Hoadley Creek & Hoadley & $\mathrm{CT}$ & 3_Southern_New_England & Academic & Estuarine Embayment \\
\hline Long Island Sound - Hoadley Creek & Hoadley & $\mathrm{CT}$ & 3_Southern_New_England & Academic & Estuarine Embayment \\
\hline Long Island Sound - Hoadley Creek & Hoadley & $\mathrm{CT}$ & 3_Southern_New_England & Academic & Estuarine Embayment \\
\hline Long Island Sound - Hoadley Creek & Hoadley & $\mathrm{CT}$ & 3_Southern_New_England & Academic & Estuarine Embayment \\
\hline Long Island Sound - Jarvis Creek & Jarvis & $\mathrm{CT}$ & 3_Southern_New_England & Academic & Estuarine Embayment \\
\hline Long Island Sound - Jarvis Creek & Jarvis & $\mathrm{CT}$ & 3_Southern_New_England & Academic & Estuarine Embayment \\
\hline Long Island Sound - Jarvis Creek & Jarvis & $\mathrm{CT}$ & 3_Southern_New_England & Academic & Estuarine Embayment \\
\hline Long Island Sound - Hoadley Creek & $\begin{array}{l}\text { Long Island Sound - Hoadley Creek_ } \\
\text { Hoadley }\end{array}$ & $\mathrm{CT}$ & 3_Southern_New_England & Academic & Estuarine Embayment \\
\hline Long Island Sound - Hoadley Creek & $\begin{array}{l}\text { Long Island Sound - Hoadley Creek_ } \\
\text { Hoadley }\end{array}$ & $\mathrm{CT}$ & 3_Southern_New_England & Academic & Estuarine Embayment \\
\hline Long Island Sound - Hoadley Creek & $\begin{array}{l}\text { Long Island Sound - Hoadley Creek_ } \\
\text { Hoadley }\end{array}$ & $\mathrm{CT}$ & 3_Southern_New_England & Academic & Estuarine Embayment \\
\hline Long Island Sound - Hoadley Creek & $\begin{array}{l}\text { Long Island Sound - Hoadley Creek_ } \\
\text { Hoadley }\end{array}$ & $\mathrm{CT}$ & 3_Southern_New_England & Academic & Estuarine Embayment \\
\hline Long Island Sound - Hoadley Creek & $\begin{array}{l}\text { Long Island Sound - Hoadley Creek } \\
\text { Hoadley }\end{array}$ & $\mathrm{CT}$ & 3_Southern_New_England & Academic & Estuarine Embayment \\
\hline Long Island Sound - Hoadley Creek & $\begin{array}{l}\text { Long Island Sound - Hoadley Creek_ } \\
\text { Hoadley }\end{array}$ & $\mathrm{CT}$ & 3_Southern_New_England & Academic & Estuarine Embayment \\
\hline Long Island Sound - Leetes Island Marsh & $\begin{array}{l}\text { Long Island Sound - Leetes Island Marsh_ } \\
\text { Leetes }\end{array}$ & $\mathrm{CT}$ & 3_Southern_New_England & Academic & \\
\hline Long Island Sound - Leetes Island Marsh & $\begin{array}{l}\text { Long Island Sound - Leetes Island Marsh_ } \\
\text { Leetes }\end{array}$ & $\mathrm{CT}$ & 3_Southern_New_England & Academic & \\
\hline
\end{tabular}


Table 2.1. Surface elevation table-marker horizon (SET-MH) data.-Continued

\begin{tabular}{|c|c|c|c|c|c|}
\hline SET_Geographical_Location & Site & State & Sub_Region & Partner & Broad_Geomophic_Setting \\
\hline Long Island Sound - Leetes Island Marsh & $\begin{array}{l}\text { Long Island Sound - Leetes Island Marsh_ } \\
\text { Leetes }\end{array}$ & $\mathrm{CT}$ & 3_Southern_New_England & Academic & \\
\hline Long Island Sound - Leetes Island Marsh & $\begin{array}{l}\text { Long Island Sound - Leetes Island Marsh_ } \\
\text { Leetes }\end{array}$ & $\mathrm{CT}$ & 3_Southern_New_England & Academic & \\
\hline Long Island Sound - Leetes Island Marsh & $\begin{array}{l}\text { Long Island Sound - Leetes Island Marsh_ } \\
\text { Leetes }\end{array}$ & $\mathrm{CT}$ & 3_Southern_New_England & Academic & \\
\hline Long Island Sound - Leetes Island Marsh & $\begin{array}{l}\text { Long Island Sound - Leetes Island Marsh_ } \\
\text { Leetes }\end{array}$ & $\mathrm{CT}$ & 3_Southern_New_England & Academic & \\
\hline Long Island Sound - Leetes Island Marsh & $\begin{array}{l}\text { Long Island Sound - Leetes Island Marsh_ } \\
\text { Leetes }\end{array}$ & $\mathrm{CT}$ & 3_Southern_New_England & Academic & \\
\hline Long Island Sound - Leetes Island Marsh & $\begin{array}{l}\text { Long Island Sound - Leetes Island Marsh_ } \\
\text { Leetes }\end{array}$ & $\mathrm{CT}$ & 3_Southern_New_England & Academic & \\
\hline Long Island Sound - Leetes Island Marsh & $\begin{array}{l}\text { Long Island Sound - Leetes Island Marsh } \\
\text { Leetes }\end{array}$ & $\mathrm{CT}$ & 3_Southern_New_England & Academic & \\
\hline Long Island Sound - Quinnipiac Estuary & $\begin{array}{l}\text { Long Island Sound - Quinnipiac Estuary_ } \\
\text { Quinnipiac }\end{array}$ & $\mathrm{CT}$ & 3_Southern_New_England & Academic & Estuarine Brackish Marsh \\
\hline Long Island Sound - Quinnipiac Estuary & $\begin{array}{l}\text { Long Island Sound - Quinnipiac Estuary_ } \\
\text { Quinnipiac }\end{array}$ & $\mathrm{CT}$ & 3_Southern_New_England & Academic & Estuarine Brackish Marsh \\
\hline Long Island Sound - Quinnipiac Estuary & $\begin{array}{l}\text { Long Island Sound - Quinnipiac Estuary_ } \\
\text { Quinnipiac }\end{array}$ & $\mathrm{CT}$ & 3_Southern_New_England & Academic & Estuarine Brackish Marsh \\
\hline Long Island Sound - Quinnipiac Estuary & $\begin{array}{l}\text { Long Island Sound - Quinnipiac Estuary_ } \\
\text { Quinnipiac }\end{array}$ & $\mathrm{CT}$ & 3_Southern_New_England & Academic & Estuarine Brackish Marsh \\
\hline Long Island Sound - Quinnipiac Estuary & $\begin{array}{l}\text { Long Island Sound - Quinnipiac Estuary_ } \\
\text { Quinnipiac }\end{array}$ & $\mathrm{CT}$ & 3_Southern_New_England & Academic & Estuarine Brackish Marsh \\
\hline Long Island Sound - Quinnipiac Estuary & $\begin{array}{l}\text { Long Island Sound - Quinnipiac Estuary_ } \\
\text { Quinnipiac }\end{array}$ & $\mathrm{CT}$ & 3_Southern_New_England & Academic & Estuarine Brackish Marsh \\
\hline Long Island Sound - Quinnipiac Estuary & $\begin{array}{l}\text { Long Island Sound - Quinnipiac Estuary_ } \\
\text { Quinnipiac }\end{array}$ & $\mathrm{CT}$ & 3_Southern_New_England & Academic & Estuarine Brackish Marsh \\
\hline Long Island Sound - Quinnipiac Estuary & $\begin{array}{l}\text { Long Island Sound - Quinnipiac Estuary_ } \\
\text { Quinnipiac }\end{array}$ & $\mathrm{CT}$ & 3_Southern_New_England & Academic & Estuarine Brackish Marsh \\
\hline Long Island Sound - Quinnipiac Estuary & $\begin{array}{l}\text { Long Island Sound - Quinnipiac Estuary_ } \\
\text { Quinnipiac }\end{array}$ & $\mathrm{CT}$ & 3_Southern_New_England & Academic & Estuarine Brackish Marsh \\
\hline $\begin{array}{l}\text { STEWART B. MCKINNEY NATIONAL } \\
\text { WILDLIFE REFUGE }\end{array}$ & GMU & $\mathrm{CT}$ & 3_Southern_New_England & USFWS & Back-barrier Lagoon Marsh \\
\hline $\begin{array}{l}\text { STEWART B. MCKINNEY NATIONAL } \\
\text { WILDLIFE REFUGE }\end{array}$ & GMU & $\mathrm{CT}$ & 3_Southern_New_England & USFWS & Back-barrier Lagoon Marsh \\
\hline
\end{tabular}


Table 2.1. Surface elevation table-marker horizon (SET-MH) data.-Continued

\begin{tabular}{|c|c|c|c|c|c|}
\hline SET_Geographical_Location & Site & State & Sub_Region & Partner & Broad_Geomophic_Setting \\
\hline $\begin{array}{l}\text { STEWART B. MCKINNEY NATIONAL } \\
\text { WILDLIFE REFUGE }\end{array}$ & GMU & $\mathrm{CT}$ & 3_Southern_New_England & USFWS & Back-barrier Lagoon Marsh \\
\hline $\begin{array}{l}\text { STEWART B. MCKINNEY NATIONAL } \\
\text { WILDLIFE REFUGE }\end{array}$ & DEP001 & $\mathrm{CT}$ & 3_Southern_New_England & USFWS & Back-barrier Lagoon Marsh \\
\hline $\begin{array}{l}\text { STEWART B. MCKINNEY NATIONAL } \\
\text { WILDLIFE REFUGE }\end{array}$ & SMU & $\mathrm{CT}$ & 3_Southern_New_England & USFWS & Estuarine Embayment \\
\hline $\begin{array}{l}\text { STEWART B. MCKINNEY NATIONAL } \\
\text { WILDLIFE REFUGE }\end{array}$ & SMU & $\mathrm{CT}$ & 3_Southern_New_England & USFWS & Estuarine Embayment \\
\hline $\begin{array}{l}\text { STEWART B. MCKINNEY NATIONAL } \\
\text { WILDLIFE REFUGE }\end{array}$ & SMU & $\mathrm{CT}$ & 3_Southern_New_England & USFWS & Estuarine Embayment \\
\hline $\begin{array}{l}\text { NINIGRET NATIONAL WILDLIFE } \\
\text { REFUGE }\end{array}$ & NIN & RI & 3_Southern_New_England & USFWS & Back-barrier Lagoon Marsh \\
\hline $\begin{array}{l}\text { NINIGRET NATIONAL WILDLIFE } \\
\text { REFUGE }\end{array}$ & NIN & RI & 3_Southern_New_England & USFWS & Back-barrier Lagoon Marsh \\
\hline $\begin{array}{l}\text { NINIGRET NATIONAL WILDLIFE } \\
\text { REFUGE }\end{array}$ & NIN & RI & 3_Southern_New_England & USFWS & Back-barrier Lagoon Marsh \\
\hline $\begin{array}{l}\text { NINIGRET NATIONAL WILDLIFE } \\
\text { REFUGE }\end{array}$ & Ninigret North & RI & 3_Southern_New_England & USFWS & Back-barrier Lagoon Marsh \\
\hline $\begin{array}{l}\text { NINIGRET NATIONAL WILDLIFE } \\
\text { REFUGE }\end{array}$ & Ninigret North & RI & 3_Southern_New_England & USFWS & Back-barrier Lagoon Marsh \\
\hline $\begin{array}{l}\text { NINIGRET NATIONAL WILDLIFE } \\
\text { REFUGE }\end{array}$ & Ninigret North & RI & 3_Southern_New_England & USFWS & Back-barrier Lagoon Marsh \\
\hline $\begin{array}{l}\text { JOHN H. CHAFEE NATIONAL WILDLIFE } \\
\text { REFUGE }\end{array}$ & SD & RI & 3_Southern_New_England & USFWS & Estuarine Embayment \\
\hline $\begin{array}{l}\text { JOHN H. CHAFEE NATIONAL WILDLIFE } \\
\text { REFUGE }\end{array}$ & SD & RI & 3_Southern_New_England & USFWS & Estuarine Embayment \\
\hline $\begin{array}{l}\text { JOHN H. CHAFEE NATIONAL WILDLIFE } \\
\text { REFUGE }\end{array}$ & JHC & RI & 3_Southern_New_England & USFWS & Estuarine Embayment \\
\hline $\begin{array}{l}\text { JOHN H. CHAFEE NATIONAL WILDLIFE } \\
\text { REFUGE }\end{array}$ & $\mathrm{JHC}$ & RI & 3_Southern_New_England & USFWS & Estuarine Embayment \\
\hline $\begin{array}{l}\text { JOHN H. CHAFEE NATIONAL WILDLIFE } \\
\text { REFUGE }\end{array}$ & JHC & RI & 3_Southern_New_England & USFWS & Estuarine Embayment \\
\hline $\begin{array}{l}\text { JOHN H. CHAFEE NATIONAL WILDLIFE } \\
\text { REFUGE }\end{array}$ & $\mathrm{JHC}$ & RI & 3_Southern_New_England & USFWS & Estuarine Embayment \\
\hline $\begin{array}{l}\text { JOHN H. CHAFEE NATIONAL WILDLIFE } \\
\text { REFUGE }\end{array}$ & Chafee & RI & 3_Southern_New_England & USFWS & Estuarine Embayment \\
\hline
\end{tabular}


Table 2.1. Surface elevation table-marker horizon (SET-MH) data.-Continued

\begin{tabular}{|c|c|c|c|c|c|}
\hline SET_Geographical_Location & Site & State & Sub_Region & Partner & Broad_Geomophic_Setting \\
\hline $\begin{array}{l}\text { JOHN H. CHAFEE NATIONAL WILDLIFE } \\
\text { REFUGE }\end{array}$ & Chafee & RI & 3_Southern_New_England & USFWS & Estuarine Embayment \\
\hline $\begin{array}{l}\text { JOHN H. CHAFEE NATIONAL WILDLIFE } \\
\text { REFUGE }\end{array}$ & Chafee & RI & 3_Southern_New_England & USFWS & Estuarine Embayment \\
\hline $\begin{array}{l}\text { JOHN H. CHAFEE NATIONAL WILDLIFE } \\
\text { REFUGE }\end{array}$ & $\mathrm{JHC}$ & RI & 3_Southern_New_England & USFWS & Estuarine Embayment \\
\hline $\begin{array}{l}\text { JOHN H. CHAFEE NATIONAL WILDLIFE } \\
\text { REFUGE }\end{array}$ & $\mathrm{JHC}$ & RI & 3_Southern_New_England & USFWS & Estuarine Embayment \\
\hline $\begin{array}{l}\text { JOHN H. CHAFEE NATIONAL WILDLIFE } \\
\text { REFUGE }\end{array}$ & $\mathrm{JHC}$ & RI & 3_Southern_New_England & USFWS & Estuarine Embayment \\
\hline $\begin{array}{l}\text { JOHN H. CHAFEE NATIONAL WILDLIFE } \\
\text { REFUGE }\end{array}$ & $\mathrm{MB}$ & RI & 3_Southern_New_England & USFWS & Estuarine Embayment \\
\hline $\begin{array}{l}\text { JOHN H. CHAFEE NATIONAL WILDLIFE } \\
\text { REFUGE }\end{array}$ & $\mathrm{MB}$ & RI & 3_Southern_New_England & USFWS & Estuarine Embayment \\
\hline $\begin{array}{l}\text { JOHN H. CHAFEE NATIONAL WILDLIFE } \\
\text { REFUGE }\end{array}$ & MB & RI & 3_Southern_New_England & USFWS & Estuarine Embayment \\
\hline $\begin{array}{l}\text { SACHUEST POINT NATIONAL } \\
\text { WILDLIFE REFUGE }\end{array}$ & SPT & RI & 3_Southern_New_England & USFWS & Back-barrier Lagoon Marsh \\
\hline $\begin{array}{l}\text { SACHUEST POINT NATIONAL } \\
\text { WILDLIFE REFUGE }\end{array}$ & SPT & RI & 3_Southern_New_England & USFWS & Back-barrier Lagoon Marsh \\
\hline $\begin{array}{l}\text { SACHUEST POINT NATIONAL } \\
\text { WILDLIFE REFUGE }\end{array}$ & SPT & RI & 3_Southern_New_England & USFWS & Back-barrier Lagoon Marsh \\
\hline $\begin{array}{l}\text { MOMOMOY NATIONAL WILDLIFE } \\
\text { REFUGE }\end{array}$ & Minimoy & MA & 3_Southern_New_England & USFWS & Back-barrier Lagoon Marsh \\
\hline $\begin{array}{l}\text { MOMOMOY NATIONAL WILDLIFE } \\
\text { REFUGE }\end{array}$ & Minimoy & MA & 3_Southern_New_England & USFWS & Back-barrier Lagoon Marsh \\
\hline Great Meadows & Great Meadows_Stratford & $\mathrm{CT}$ & 3_Southern_New_England & USFWS & Back-barrier Lagoon Marsh \\
\hline Great Meadows & Great Meadows_Stratford & $\mathrm{CT}$ & 3_Southern_New_England & USFWS & Back-barrier Lagoon Marsh \\
\hline Great Meadows & Great Meadows_Stratford & $\mathrm{CT}$ & 3_Southern_New_England & USFWS & Back-barrier Lagoon Marsh \\
\hline Great Meadows, NWR & Great.Meadows & $\mathrm{CT}$ & 3_Southern_New_England & USGS & Back-barrier Lagoon Marsh \\
\hline Great Meadows, NWR & Great.Meadows & $\mathrm{CT}$ & 3_Southern_New_England & USGS & Back-barrier Lagoon Marsh \\
\hline
\end{tabular}


Table 2.1. Surface elevation table-marker horizon (SET-MH) data.-Continued

\begin{tabular}{|c|c|c|c|c|c|}
\hline SET_Geographical_Location & Site & State & Sub_Region & Partner & Broad_Geomophic_Setting \\
\hline Great Meadows, NWR & Great.Meadows & $\mathrm{CT}$ & 3_Southern_New_England & USGS & Back-barrier Lagoon Marsh \\
\hline Great Meadows, NWR & Great.Meadows & CT & 3_Southern_New_England & USGS & Back-barrier Lagoon Marsh \\
\hline Waquoit Bay NERR & Waquoit Bay NERR_Section1 & MA & 3_Southern_New_England & NERR & Back-barrier Lagoon Marsh \\
\hline Waquoit Bay NERR & Waquoit Bay NERR_Section1 & MA & 3_Southern_New_England & NERR & Back-barrier Lagoon Marsh \\
\hline Waquoit Bay NERR & Waquoit Bay NERR_Section1 & MA & 3_Southern_New_England & NERR & Back-barrier Lagoon Marsh \\
\hline Waquoit Bay NERR & Waquoit Bay NERR_Section1 & MA & 3_Southern_New_England & NERR & Back-barrier Lagoon Marsh \\
\hline Waquoit Bay NERR & Waquoit Bay NERR_Section3 & MA & 3_Southern_New_England & NERR & Back-barrier Lagoon Marsh \\
\hline Waquoit Bay NERR & Waquoit Bay NERR_Section3 & MA & 3_Southern_New_England & NERR & Back-barrier Lagoon Marsh \\
\hline Waquoit Bay NERR & Waquoit Bay NERR_Section3 & MA & 3_Southern_New_England & NERR & Back-barrier Lagoon Marsh \\
\hline Waquoit Bay NERR & Waquoit Bay NERR_Section2 & MA & 3_Southern_New_England & NERR & Back-barrier Lagoon Marsh \\
\hline Waquoit Bay NERR & Waquoit Bay NERR_Section2 & MA & 3_Southern_New_England & NERR & Back-barrier Lagoon Marsh \\
\hline Waquoit Bay NERR & Waquoit Bay NERR_Section2 & MA & 3_Southern_New_England & NERR & Back-barrier Lagoon Marsh \\
\hline Waquoit Bay NERR & Waquoit Bay NERR_Section3 & MA & 3_Southern_New_England & NERR & Back-barrier Lagoon Marsh \\
\hline Waquoit Bay NERR & Waquoit Bay NERR_Section2 & MA & 3_Southern_New_England & NERR & Back-barrier Lagoon Marsh \\
\hline Idlewild Park, Queens, NY & Idlewild Park, Queens, NY_IP & NY & 4_Long_Island & NYC & Estuarine Embayment \\
\hline Idlewild Park, Queens, NY & Idlewild Park, Queens, NY_IP & NY & 4_Long_Island & NYC & Estuarine Embayment \\
\hline Idlewild Park, Queens, NY & Idlewild Park, Queens, NY_IP & NY & 4_Long_Island & NYC & Estuarine Embayment \\
\hline Spring Creek Park, Queens, NY & Spring Creek Park, Queens, NY_SC & NY & 4_Long_Island & NYC & Estuarine Embayment \\
\hline
\end{tabular}


Table 2.1. Surface elevation table-marker horizon (SET-MH) data.-Continued

\begin{tabular}{|c|c|c|c|c|c|}
\hline SET_Geographical_Location & Site & State & Sub_Region & Partner & Broad_Geomophic_Setting \\
\hline Spring Creek Park, Queens, NY & Spring Creek Park, Queens, NY_SC & NY & 4_Long_Island & NYC & Estuarine Embayment \\
\hline Spring Creek Park, Queens, NY & Spring Creek Park, Queens, NY_SC & NY & 4_Long_Island & NYC & Estuarine Embayment \\
\hline Udall's Cove Park Preserve, Queens, NY & $\begin{array}{l}\text { Udall's Cove Park Preserve, Queens, } \\
\text { NY_UC }\end{array}$ & NY & 4_Long_Island & NYC & Estuarine Embayment \\
\hline Udall's Cove Park Preserve, Queens, NY & $\begin{array}{l}\text { Udall's Cove Park Preserve, Queens, } \\
\text { NY_UC }\end{array}$ & NY & 4_Long_Island & NYC & Estuarine Embayment \\
\hline Udall's Cove Park Preserve, Queens, NY & $\begin{array}{l}\text { Udall's Cove Park Preserve, Queens, } \\
\text { NY_UC }\end{array}$ & NY & 4_Long_Island & NYC & Estuarine Embayment \\
\hline Jamaica Bay, NY & GATE.Big.Egg.Spray & NY & 4_Long_Island & NPS & Back-barrier Lagoon Marsh \\
\hline Jamaica Bay, NY & GATE.Big.Egg.Spray & NY & 4_Long_Island & NPS & Back-barrier Lagoon Marsh \\
\hline Jamaica Bay, NY & GATE.JOCO.REF & NY & 4_Long_Island & NPS & Back-barrier Lagoon Marsh \\
\hline Jamaica Bay, NY & GATE.JOCO.REF & NY & 4_Long_Island & NPS & Back-barrier Lagoon Marsh \\
\hline Jamaica Bay, NY & GATE.JOCO.REF & NY & 4_Long_Island & NPS & Back-barrier Lagoon Marsh \\
\hline Jamaica Bay, NY & GATE.JOCO & NY & 4_Long_Island & NPS & Back-barrier Lagoon Marsh \\
\hline Jamaica Bay, NY & GATE.JOCO & NY & 4_Long_Island & NPS & Back-barrier Lagoon Marsh \\
\hline Jamaica Bay, NY & GATE.JOCO & NY & 4_Long_Island & NPS & Back-barrier Lagoon Marsh \\
\hline Jamaica Bay, NY & GATE.Black.Bank & NY & 4_Long_Island & NPS & Back-barrier Lagoon Marsh \\
\hline Jamaica Bay, NY & GATE.Elders.East & NY & 4_Long_Island & NPS & Back-barrier Lagoon Marsh \\
\hline Jamaica Bay, NY & GATE.Elders.East & NY & 4_Long_Island & NPS & Back-barrier Lagoon Marsh \\
\hline Fire Island NS, NY & FIIS.Watch.Hill & NY & 4_Long_Island & NPS & Back-barrier Lagoon Marsh \\
\hline Fire Island NS, NY & FIIS.Watch.Hill & NY & 4_Long_Island & NPS & Back-barrier Lagoon Marsh \\
\hline
\end{tabular}


Table 2.1. Surface elevation table-marker horizon (SET-MH) data.-Continued

\begin{tabular}{|c|c|c|c|c|c|}
\hline SET_Geographical_Location & Site & State & Sub_Region & Partner & Broad_Geomophic_Setting \\
\hline Fire Island NS, NY & FIIS.Watch.Hill & NY & 4_Long_Island & NPS & Back-barrier Lagoon Marsh \\
\hline Fire Island NS, NY & FIIS.Hospital.Point & NY & 4_Long_Island & NPS & Back-barrier Lagoon Marsh \\
\hline Fire Island NS, NY & FIIS.Hospital.Point & NY & 4_Long_Island & NPS & Back-barrier Lagoon Marsh \\
\hline Fire Island NS, NY & FIIS.Hospital.Point & NY & 4_Long_Island & NPS & Back-barrier Lagoon Marsh \\
\hline Fire Island NS, NY & FIIS.Great.Gun & NY & 4_Long_Island & NPS & Back-barrier Lagoon Marsh \\
\hline Fire Island NS, NY & FIIS.Great.Gun & NY & 4_Long_Island & NPS & Back-barrier Lagoon Marsh \\
\hline Jamaica Bay, NY & GATE.Big.Egg.Reference & NY & 4_Long_Island & NPS & Back-barrier Lagoon Marsh \\
\hline Jamaica Bay, NY & GATE.Big.Egg.Spray & NY & 4_Long_Island & NPS & Back-barrier Lagoon Marsh \\
\hline Jamaica Bay, NY & GATE.Big.Egg.Reference & NY & 4_Long_Island & NPS & Back-barrier Lagoon Marsh \\
\hline Jamaica Bay, NY & GATE.Big.Egg.Reference & NY & 4_Long_Island & NPS & Back-barrier Lagoon Marsh \\
\hline Jamaica Bay, NY & GATE.Black.Bank & NY & 4_Long_Island & NPS & Back-barrier Lagoon Marsh \\
\hline Jamaica Bay, NY & GATE.Black.Bank & NY & 4_Long_Island & NPS & Back-barrier Lagoon Marsh \\
\hline Jamaica Bay, NY & GATE.Elders.East.NF & NY & 4_Long_Island & NPS & Back-barrier Lagoon Marsh \\
\hline Jamaica Bay, NY & GATE.Elders.East.NF & NY & 4_Long_Island & NPS & Back-barrier Lagoon Marsh \\
\hline Jamaica Bay, NY & GATE.Elders.East.NF & NY & 4_Long_Island & NPS & Back-barrier Lagoon Marsh \\
\hline Jamaica Bay, NY & GATE.Elders.East & NY & 4_Long_Island & NPS & Back-barrier Lagoon Marsh \\
\hline Fire Island NS, NY & FIIS.Great.Gun & NY & 4_Long_Island & NPS & Back-barrier Lagoon Marsh \\
\hline East Creek-Sands Point, NY & $\mathrm{EC}$ & NY & 4_Long_Island & NYS & Back-barrier Lagoon Marsh \\
\hline
\end{tabular}


Table 2.1. Surface elevation table-marker horizon (SET-MH) data.-Continued

\begin{tabular}{|c|c|c|c|c|c|}
\hline SET_Geographical_Location & Site & State & Sub_Region & Partner & Broad_Geomophic_Setting \\
\hline East Creek-Sands Point, NY & $\mathrm{EC}$ & NY & 4_Long_Island & NYS & Back-barrier Lagoon Marsh \\
\hline East Creek-Sands Point, NY & $\mathrm{EC}$ & NY & 4_Long_Island & NYS & Back-barrier Lagoon Marsh \\
\hline West Pond-Glen Cove, NY & WP & NY & 4_Long_Island & NYS & Back-barrier Lagoon Marsh \\
\hline West Pond-Glen Cove, NY & WP & NY & 4_Long_Island & NYS & Back-barrier Lagoon Marsh \\
\hline West Pond-Glen Cove, NY & WP & NY & 4_Long_Island & NYS & Back-barrier Lagoon Marsh \\
\hline Frost Creek-Lattingtown, NY & $\mathrm{FC}$ & NY & 4_Long_Island & NYS & Back-barrier Lagoon Marsh \\
\hline Frost Creek-Lattingtown, NY & $\mathrm{FC}$ & NY & 4_Long_Island & NYS & Back-barrier Lagoon Marsh \\
\hline Frost Creek-Lattingtown, NY & $\mathrm{FC}$ & NY & 4_Long_Island & NYS & Back-barrier Lagoon Marsh \\
\hline Flax Pond-Old Field, NY & FP & NY & 4_Long_Island & NYS & Back-barrier Lagoon Marsh \\
\hline Flax Pond-Old Field, NY & FP & NY & 4_Long_Island & NYS & Back-barrier Lagoon Marsh \\
\hline Flax Pond-Old Field, NY & FP & NY & 4_Long_Island & NYS & Back-barrier Lagoon Marsh \\
\hline Long Island, New York & Bass.Creek & NY & 4_Long_Island & TNC & Back-barrier Lagoon Marsh \\
\hline Long Island, New York & Bass.Creek & NY & 4_Long_Island & TNC & Back-barrier Lagoon Marsh \\
\hline Long Island, New York & Bass.Creek & NY & 4_Long_Island & TNC & Back-barrier Lagoon Marsh \\
\hline Long Island, New York & Lawrence.Marsh & NY & 4_Long_Island & $\mathrm{TNC}$ & Back-barrier Lagoon Marsh \\
\hline Long Island, New York & Lawrence.Marsh & NY & 4_Long_Island & $\mathrm{TNC}$ & Back-barrier Lagoon Marsh \\
\hline Long Island, New York & Lawrence.Marsh & NY & 4_Long_Island & TNC & Back-barrier Lagoon Marsh \\
\hline Long Island, New York & North.Greensedge.West.Hempstead & NY & 4_Long_Island & $\mathrm{TNC}$ & Back-barrier Lagoon Marsh \\
\hline
\end{tabular}


Table 2.1. Surface elevation table-marker horizon (SET-MH) data.-Continued

\begin{tabular}{|c|c|c|c|c|c|}
\hline SET_Geographical_Location & Site & State & Sub_Region & Partner & Broad_Geomophic_Setting \\
\hline Long Island, New York & North.Greensedge.West.Hempstead & NY & 4_Long_Island & $\mathrm{TNC}$ & Back-barrier Lagoon Marsh \\
\hline Long Island, New York & North.Greensedge.West.Hempstead & NY & 4_Long_Island & $\mathrm{TNC}$ & Back-barrier Lagoon Marsh \\
\hline Long Island, New York & Pine.Neck & NY & 4_Long_Island & $\mathrm{TNC}$ & Back-barrier Lagoon Marsh \\
\hline Long Island, New York & Pine.Neck & NY & 4_Long_Island & $\mathrm{TNC}$ & Back-barrier Lagoon Marsh \\
\hline Long Island, New York & Pine.Neck & NY & 4_Long_Island & $\mathrm{TNC}$ & Back-barrier Lagoon Marsh \\
\hline Long Island, New York & Pine.Neck & NY & 4_Long_Island & $\mathrm{TNC}$ & Back-barrier Lagoon Marsh \\
\hline Long Island, New York & Pine.Neck & NY & 4_Long_Island & $\mathrm{TNC}$ & Back-barrier Lagoon Marsh \\
\hline Long Island, New York & Pine.Neck & NY & 4_Long_Island & $\mathrm{TNC}$ & Back-barrier Lagoon Marsh \\
\hline Long Island, New York & Hubbard.Creek & NY & 4_Long_Island & $\mathrm{TNC}$ & Back-barrier Lagoon Marsh \\
\hline Long Island, New York & Hubbard.Creek & NY & 4_Long_Island & $\mathrm{TNC}$ & Back-barrier Lagoon Marsh \\
\hline Long Island, New York & Hubbard.Creek & NY & 4_Long_Island & $\mathrm{TNC}$ & Back-barrier Lagoon Marsh \\
\hline Long Island, New York & Indian.Island & NY & 4_Long_Island & TNC & Estuarine Embayment \\
\hline Long Island, New York & Indian.Island & NY & 4_Long_Island & $\mathrm{TNC}$ & Estuarine Embayment \\
\hline Long Island, New York & Indian.Island & NY & 4_Long_Island & $\mathrm{TNC}$ & Estuarine Embayment \\
\hline Long Island, New York & Indian.Island & NY & 4_Long_Island & $\mathrm{TNC}$ & Estuarine Embayment \\
\hline Long Island, New York & Indian.Island & NY & 4_Long_Island & TNC & Estuarine Embayment \\
\hline Long Island, New York & Indian.Island & NY & 4_Long_Island & $\mathrm{TNC}$ & Estuarine Embayment \\
\hline Long Island, New York & Accabonac.Harbor & NY & 4_Long_Island & $\mathrm{TNC}$ & Back-barrier Lagoon Marsh \\
\hline
\end{tabular}


Table 2.1. Surface elevation table-marker horizon (SET-MH) data.-Continued

\begin{tabular}{|c|c|c|c|c|c|}
\hline SET_Geographical_Location & Site & State & Sub_Region & Partner & Broad_Geomophic_Setting \\
\hline Long Island, New York & Accabonac.Harbor & NY & 4_Long_Island & $\mathrm{TNC}$ & Back-barrier Lagoon Marsh \\
\hline Long Island, New York & Accabonac.Harbor & NY & 4_Long_Island & TNC & Back-barrier Lagoon Marsh \\
\hline Long Island, New York & Mashomack.Point & NY & 4_Long_Island & $\mathrm{TNC}$ & Back-barrier Lagoon Marsh \\
\hline Long Island, New York & Mashomack.Point & NY & 4_Long_Island & $\mathrm{TNC}$ & Back-barrier Lagoon Marsh \\
\hline Long Island, New York & Mashomack.Point & NY & 4_Long_Island & $\mathrm{TNC}$ & Back-barrier Lagoon Marsh \\
\hline Long Island, New York & Cedar.Beach & NY & 4_Long_Island & $\mathrm{TNC}$ & Back-barrier Lagoon Marsh \\
\hline Long Island, New York & Cedar.Beach & NY & 4_Long_Island & $\mathrm{TNC}$ & Back-barrier Lagoon Marsh \\
\hline Long Island, New York & Cedar.Beach & NY & 4_Long_Island & $\mathrm{TNC}$ & Back-barrier Lagoon Marsh \\
\hline $\begin{array}{l}\text { SEATUCK NATIONAL WILDLIFE } \\
\text { REFUGE }\end{array}$ & Lido Beach & NY & 4_Long_Island & USFWS & Back-barrier Lagoon Marsh \\
\hline $\begin{array}{l}\text { SEATUCK NATIONAL WILDLIFE } \\
\text { REFUGE }\end{array}$ & Lido Beach & NY & 4_Long_Island & USFWS & Back-barrier Lagoon Marsh \\
\hline $\begin{array}{l}\text { SEATUCK NATIONAL WILDLIFE } \\
\text { REFUGE }\end{array}$ & Lido Beach & NY & 4_Long_Island & USFWS & Back-barrier Lagoon Marsh \\
\hline $\begin{array}{l}\text { SEATUCK NATIONAL WILDLIFE } \\
\text { REFUGE }\end{array}$ & Seatuck & NY & 4_Long_Island & USFWS & Back-barrier Lagoon Marsh \\
\hline $\begin{array}{l}\text { SEATUCK NATIONAL WILDLIFE } \\
\text { REFUGE }\end{array}$ & Seatuck & NY & 4_Long_Island & USFWS & Back-barrier Lagoon Marsh \\
\hline $\begin{array}{l}\text { SEATUCK NATIONAL WILDLIFE } \\
\text { REFUGE }\end{array}$ & Seatuck & NY & 4_Long_Island & USFWS & Back-barrier Lagoon Marsh \\
\hline $\begin{array}{l}\text { SEATUCK NATIONAL WILDLIFE } \\
\text { REFUGE }\end{array}$ & Seatuck & NY & 4_Long_Island & USFWS & Back-barrier Lagoon Marsh \\
\hline $\begin{array}{l}\text { SEATUCK NATIONAL WILDLIFE } \\
\text { REFUGE }\end{array}$ & Seatuck & NY & 4_Long_Island & USFWS & Back-barrier Lagoon Marsh \\
\hline $\begin{array}{l}\text { SEATUCK NATIONAL WILDLIFE } \\
\text { REFUGE }\end{array}$ & Seatuck & NY & 4_Long_Island & USFWS & Back-barrier Lagoon Marsh \\
\hline Wertheim NWR, NY & WWU & NY & 4_Long_Island & USFWS & Back-barrier Lagoon Marsh \\
\hline
\end{tabular}


Table 2.1. Surface elevation table-marker horizon (SET-MH) data.-Continued

\begin{tabular}{|c|c|c|c|c|c|}
\hline SET_Geographical_Location & Site & State & Sub_Region & Partner & Broad_Geomophic_Setting \\
\hline Wertheim NWR, NY & WWU & NY & 4_Long_Island & USFWS & Back-barrier Lagoon Marsh \\
\hline Wertheim NWR, NY & WWU & NY & 4_Long_Island & USFWS & Back-barrier Lagoon Marsh \\
\hline Smith Point, NY & Smith.Point & NY & 4_Long_Island & USFWS & Back-barrier Lagoon Marsh \\
\hline Smith Point, NY & Smith.Point & NY & 4_Long_Island & USFWS & Back-barrier Lagoon Marsh \\
\hline Smith Point, NY & Smith.Point & NY & 4_Long_Island & USFWS & Back-barrier Lagoon Marsh \\
\hline Wertheim NWR, NY & WEU & NY & 4_Long_Island & USFWS & Back-barrier Lagoon Marsh \\
\hline Wertheim NWR, NY & WEU & NY & 4_Long_Island & USFWS & Back-barrier Lagoon Marsh \\
\hline Wertheim NWR, NY & WEU & NY & 4_Long_Island & USFWS & Back-barrier Lagoon Marsh \\
\hline Wertheim NWR, NY & WNU & NY & 4_Long_Island & USFWS & Back-barrier Lagoon Marsh \\
\hline Wertheim NWR, NY & WNU & NY & 4_Long_Island & USFWS & Back-barrier Lagoon Marsh \\
\hline Wertheim NWR, NY & WNU & NY & 4_Long_Island & USFWS & Back-barrier Lagoon Marsh \\
\hline Absecon, New Jersey & Absecon, New Jersey_Absecon & NJ & 5_Coastal_New_Jersey & USGS & Back-barrier Lagoon Marsh \\
\hline Absecon, New Jersey & Absecon, New Jersey_Absecon & NJ & 5_Coastal_New_Jersey & USGS & Back-barrier Lagoon Marsh \\
\hline Absecon, New Jersey & Absecon, New Jersey_Absecon & NJ & 5_Coastal_New_Jersey & USGS & Back-barrier Lagoon Marsh \\
\hline Absecon, New Jersey & Absecon, New Jersey_Fish Island South & $\mathrm{NJ}$ & 5_Coastal_New_Jersey & USGS & Back-barrier Lagoon Marsh \\
\hline Absecon, New Jersey & Absecon, New Jersey_Middle Island & NJ & 5_Coastal_New_Jersey & USGS & Back-barrier Lagoon Marsh \\
\hline Absecon, New Jersey & Absecon, New Jersey_Fish Island North & NJ & 5_Coastal_New_Jersey & USGS & Back-barrier Lagoon Marsh \\
\hline $\begin{array}{l}\text { Forsythe NWR- West Creek, NJ (Barnegat } \\
\text { Bay) }\end{array}$ & West Creek & NJ & 5_Coastal_New_Jersey & Other & Back-barrier Lagoon Marsh \\
\hline
\end{tabular}


Table 2.1. Surface elevation table-marker horizon (SET-MH) data.-Continued

\begin{tabular}{|c|c|c|c|c|c|}
\hline SET_Geographical_Location & Site & State & Sub_Region & Partner & Broad_Geomophic_Setting \\
\hline $\begin{array}{l}\text { Forsythe NWR- West Creek, NJ (Barnegat } \\
\text { Bay) }\end{array}$ & West Creek & NJ & 5_Coastal_New_Jersey & Other & Back-barrier Lagoon Marsh \\
\hline $\begin{array}{l}\text { Forsythe NWR- West Creek, NJ (Barnegat } \\
\text { Bay) }\end{array}$ & West Creek & NJ & 5_Coastal_New_Jersey & Other & Back-barrier Lagoon Marsh \\
\hline Island Beach State Park, NJ (Barnegat Bay) & Island Beach State Park & NJ & 5_Coastal_New_Jersey & Other & Back-barrier Lagoon Marsh \\
\hline Island Beach State Park, NJ (Barnegat Bay) & Island Beach State Park & NJ & 5_Coastal_New_Jersey & Other & Back-barrier Lagoon Marsh \\
\hline Island Beach State Park, NJ (Barnegat Bay) & Island Beach State Park & NJ & 5_Coastal_New_Jersey & Other & Back-barrier Lagoon Marsh \\
\hline $\begin{array}{l}\text { Forsythe NWR- Mantoloking, NJ (Barnegat } \\
\text { Bay) }\end{array}$ & Reedy Creek & NJ & 5_Coastal_New_Jersey & Other & Back-barrier Lagoon Marsh \\
\hline $\begin{array}{l}\text { Forsythe NWR- Mantoloking, NJ (Barnegat } \\
\text { Bay) }\end{array}$ & Reedy Creek & NJ & 5_Coastal_New_Jersey & Other & Back-barrier Lagoon Marsh \\
\hline $\begin{array}{l}\text { Forsythe NWR- Mantoloking, NJ (Barnegat } \\
\text { Bay) }\end{array}$ & Reedy Creek & NJ & 5_Coastal_New_Jersey & Other & Back-barrier Lagoon Marsh \\
\hline Saw Mill Creek Marsh, Staten Island, NY & Saw Mill Creek, Staten Island, NY_SM & NY & 5_Coastal_New_Jersey & NYC & Estuarine Embayment \\
\hline Saw Mill Creek Marsh, Staten Island, NY & Saw Mill Creek, Staten Island, NY_SM & NY & 5_Coastal_New_Jersey & NYC & Estuarine Embayment \\
\hline Saw Mill Creek Marsh, Staten Island, NY & Saw Mill Creek, Staten Island, NY_SM & NY & 5_Coastal_New_Jersey & NYC & Estuarine Embayment \\
\hline NJ Meadowlands & WS.1 & NJ & 5_Coastal_New_Jersey & MERI & Estuarine Brackish Marsh \\
\hline NJ Meadowlands & WS.2 & NJ & 5_Coastal_New_Jersey & MERI & Estuarine Brackish Marsh \\
\hline NJ Meadowlands & WS.3 & NJ & 5_Coastal_New_Jersey & MERI & Estuarine Brackish Marsh \\
\hline NJ Meadowlands & EDS.1 & NJ & 5_Coastal_New_Jersey & MERI & Estuarine Brackish Marsh \\
\hline NJ Meadowlands & EDS.3 & NJ & 5_Coastal_New_Jersey & MERI & Estuarine Brackish Marsh \\
\hline NJ Meadowlands & EDS.2 & NJ & 5_Coastal_New_Jersey & MERI & Estuarine Brackish Marsh \\
\hline NJ Meadowlands & RB.4 & NJ & 5_Coastal_New_Jersey & MERI/FDU & Estuarine Brackish Marsh \\
\hline
\end{tabular}


Table 2.1. Surface elevation table-marker horizon (SET-MH) data.-Continued

\begin{tabular}{|c|c|c|c|c|c|}
\hline SET_Geographical_Location & Site & State & Sub_Region & Partner & Broad_Geomophic_Setting \\
\hline NJ Meadowlands & RB.6 & NJ & 5_Coastal_New_Jersey & MERI/FDU & Estuarine Brackish Marsh \\
\hline NJ Meadowlands & RB.5 & NJ & 5_Coastal_New_Jersey & MERI/FDU & Estuarine Brackish Marsh \\
\hline NJ Meadowlands & RB.1 & NJ & 5_Coastal_New_Jersey & MERI/FDU & Estuarine Brackish Marsh \\
\hline NJ Meadowlands & RB.2 & NJ & 5_Coastal_New_Jersey & MERI/FDU & Estuarine Brackish Marsh \\
\hline NJ Meadowlands & RB.3 & NJ & 5_Coastal_New_Jersey & MERI/FDU & Estuarine Brackish Marsh \\
\hline NJ Meadowlands & SM.1 & NJ & 5_Coastal_New_Jersey & MERI/FDU & Estuarine Brackish Marsh \\
\hline NJ Meadowlands & SM.2 & NJ & 5_Coastal_New_Jersey & MERI/FDU & Estuarine Brackish Marsh \\
\hline NJ Meadowlands & SM.3 & NJ & 5_Coastal_New_Jersey & MERI/FDU & Estuarine Brackish Marsh \\
\hline NJ Meadowlands & LR.1 & $\mathrm{NJ}$ & 5_Coastal_New_Jersey & MERI/FDU & Estuarine Brackish Marsh \\
\hline NJ Meadowlands & LR.2 & NJ & 5_Coastal_New_Jersey & MERI/FDU & Estuarine Brackish Marsh \\
\hline NJ Meadowlands & LR.3 & NJ & 5_Coastal_New_Jersey & MERI/FDU & Estuarine Brackish Marsh \\
\hline NJ Meadowlands & SHS.1 & NJ & 5_Coastal_New_Jersey & MERI/FDU & Estuarine Brackish Marsh \\
\hline NJ Meadowlands & SHS.2 & NJ & 5_Coastal_New_Jersey & MERI/FDU & Estuarine Brackish Marsh \\
\hline NJ Meadowlands & SHS.3 & NJ & 5_Coastal_New_Jersey & MERI/FDU & Estuarine Brackish Marsh \\
\hline Sandy Hook NJ & GATE.Sandy.Hook & $\mathrm{NJ}$ & 5_Coastal_New_Jersey & NPS & Back-barrier Lagoon Marsh \\
\hline Sandy Hook NJ & GATE.Sandy.Hook & NJ & 5_Coastal_New_Jersey & NPS & Back-barrier Lagoon Marsh \\
\hline Sandy Hook NJ & GATE.Sandy.Hook & NJ & 5_Coastal_New_Jersey & NPS & Back-barrier Lagoon Marsh \\
\hline $\begin{array}{l}\text { CAPE MAY NATIONAL WILDLIFE } \\
\text { REFUGE }\end{array}$ & TMBU02 & NJ & 5_Coastal_New_Jersey & USFWS & Back-barrier Lagoon Marsh \\
\hline
\end{tabular}


Table 2.1. Surface elevation table-marker horizon (SET-MH) data.-Continued

\begin{tabular}{|c|c|c|c|c|c|}
\hline SET_Geographical_Location & Site & State & Sub_Region & Partner & Broad_Geomophic_Setting \\
\hline $\begin{array}{l}\text { CAPE MAY NATIONAL WILDLIFE } \\
\text { REFUGE }\end{array}$ & TMBU01 & NJ & 5_Coastal_New_Jersey & USFWS & Back-barrier Lagoon Marsh \\
\hline $\begin{array}{l}\text { CAPE MAY NATIONAL WILDLIFE } \\
\text { REFUGE }\end{array}$ & TMBU03 & NJ & 5_Coastal_New_Jersey & USFWS & Back-barrier Lagoon Marsh \\
\hline $\begin{array}{l}\text { CAPE MAY NATIONAL WILDLIFE } \\
\text { REFUGE }\end{array}$ & Cedar Headwaters01 & NJ & 5_Coastal_New_Jersey & USFWS & Back-barrier Lagoon Marsh \\
\hline $\begin{array}{l}\text { CAPE MAY NATIONAL WILDLIFE } \\
\text { REFUGE }\end{array}$ & Cedar Headwaters02 & NJ & 5_Coastal_New_Jersey & USFWS & Back-barrier Lagoon Marsh \\
\hline $\begin{array}{l}\text { CAPE MAY NATIONAL WILDLIFE } \\
\text { REFUGE }\end{array}$ & Cedar Headwaters03 & NJ & 5_Coastal_New_Jersey & USFWS & Back-barrier Lagoon Marsh \\
\hline $\begin{array}{l}\text { CAPE MAY NATIONAL WILDLIFE } \\
\text { REFUGE }\end{array}$ & Cedar Swamp01 & NJ & 5_Coastal_New_Jersey & USFWS & Back-barrier Lagoon Marsh \\
\hline $\begin{array}{l}\text { CAPE MAY NATIONAL WILDLIFE } \\
\text { REFUGE }\end{array}$ & Cedar Swamp02 & NJ & 5_Coastal_New_Jersey & USFWS & Back-barrier Lagoon Marsh \\
\hline $\begin{array}{l}\text { CAPE MAY NATIONAL WILDLIFE } \\
\text { REFUGE }\end{array}$ & Cedar Swamp03 & NJ & 5_Coastal_New_Jersey & USFWS & Back-barrier Lagoon Marsh \\
\hline $\begin{array}{l}\text { EDWIN B. FORSYTHE NATIONAL } \\
\text { WILDLIFE REFUGE }\end{array}$ & Reeds Bay/Hamm Cove SET 03 & NJ & 5_Coastal_New_Jersey & USFWS & Back-barrier Lagoon Marsh \\
\hline $\begin{array}{l}\text { EDWIN B. FORSYTHE NATIONAL } \\
\text { WILDLIFE REFUGE }\end{array}$ & Wildlife Drive 03 & NJ & 5_Coastal_New_Jersey & USFWS & Back-barrier Lagoon Marsh \\
\hline $\begin{array}{l}\text { EDWIN B. FORSYTHE NATIONAL } \\
\text { WILDLIFE REFUGE }\end{array}$ & EAST POOL & NJ & 5_Coastal_New_Jersey & USFWS & Back-barrier Lagoon Marsh \\
\hline $\begin{array}{l}\text { EDWIN B. FORSYTHE NATIONAL } \\
\text { WILDLIFE REFUGE }\end{array}$ & East Pool 02 & NJ & 5_Coastal_New_Jersey & USFWS & Back-barrier Lagoon Marsh \\
\hline $\begin{array}{l}\text { EDWIN B. FORSYTHE NATIONAL } \\
\text { WILDLIFE REFUGE }\end{array}$ & East Pool 01 & NJ & 5_Coastal_New_Jersey & USFWS & Back-barrier Lagoon Marsh \\
\hline $\begin{array}{l}\text { EDWIN B. FORSYTHE NATIONAL } \\
\text { WILDLIFE REFUGE }\end{array}$ & Wildlife Drive 02 & NJ & 5_Coastal_New_Jersey & USFWS & Back-barrier Lagoon Marsh \\
\hline $\begin{array}{l}\text { EDWIN B. FORSYTHE NATIONAL } \\
\text { WILDLIFE REFUGE }\end{array}$ & Galloway South 02 & NJ & 5_Coastal_New_Jersey & USFWS & Back-barrier Lagoon Marsh \\
\hline $\begin{array}{l}\text { EDWIN B. FORSYTHE NATIONAL } \\
\text { WILDLIFE REFUGE }\end{array}$ & Galloway South 01 & NJ & 5_Coastal_New_Jersey & USFWS & Back-barrier Lagoon Marsh \\
\hline $\begin{array}{l}\text { EDWIN B. FORSYTHE NATIONAL } \\
\text { WILDLIFE REFUGE }\end{array}$ & Galloway South 03 & NJ & 5_Coastal_New_Jersey & USFWS & Back-barrier Lagoon Marsh \\
\hline $\begin{array}{l}\text { EDWIN B. FORSYTHE NATIONAL } \\
\text { WILDLIFE REFUGE }\end{array}$ & Wildlife Drive 01 & NJ & 5_Coastal_New_Jersey & USFWS & Back-barrier Lagoon Marsh \\
\hline
\end{tabular}


Table 2.1. Surface elevation table-marker horizon (SET-MH) data.-Continued

\begin{tabular}{|c|c|c|c|c|c|}
\hline SET_Geographical_Location & Site & State & Sub_Region & Partner & Broad_Geomophic_Setting \\
\hline $\begin{array}{l}\text { EDWIN B. FORSYTHE NATIONAL } \\
\text { WILDLIFE REFUGE }\end{array}$ & Galloway North 02 & NJ & 5_Coastal_New_Jersey & USFWS & Back-barrier Lagoon Marsh \\
\hline $\begin{array}{l}\text { EDWIN B. FORSYTHE NATIONAL } \\
\text { WILDLIFE REFUGE }\end{array}$ & Wildlife Drive 04 & NJ & 5_Coastal_New_Jersey & USFWS & Back-barrier Lagoon Marsh \\
\hline $\begin{array}{l}\text { EDWIN B. FORSYTHE NATIONAL } \\
\text { WILDLIFE REFUGE }\end{array}$ & Galloway North 03 & NJ & 5_Coastal_New_Jersey & USFWS & Back-barrier Lagoon Marsh \\
\hline $\begin{array}{l}\text { EDWIN B. FORSYTHE NATIONAL } \\
\text { WILDLIFE REFUGE }\end{array}$ & Galloway North 01 & NJ & 5_Coastal_New_Jersey & USFWS & Back-barrier Lagoon Marsh \\
\hline $\begin{array}{l}\text { EDWIN B. FORSYTHE NATIONAL } \\
\text { WILDLIFE REFUGE }\end{array}$ & Reeds Bay SET 02 & NJ & 5_Coastal_New_Jersey & USFWS & Back-barrier Lagoon Marsh \\
\hline $\begin{array}{l}\text { EDWIN B. FORSYTHE NATIONAL } \\
\text { WILDLIFE REFUGE }\end{array}$ & Reeds Bay/Hamm Cove SET 01 & NJ & 5_Coastal_New_Jersey & USFWS & Back-barrier Lagoon Marsh \\
\hline $\begin{array}{l}\text { EDWIN B. FORSYTHE NATIONAL } \\
\text { WILDLIFE REFUGE }\end{array}$ & Oyster Creek SET 03 & NJ & 5_Coastal_New_Jersey & USFWS & Back-barrier Lagoon Marsh \\
\hline $\begin{array}{l}\text { EDWIN B. FORSYTHE NATIONAL } \\
\text { WILDLIFE REFUGE }\end{array}$ & Oyster Creek SET 02 & NJ & 5_Coastal_New_Jersey & USFWS & Back-barrier Lagoon Marsh \\
\hline $\begin{array}{l}\text { EDWIN B. FORSYTHE NATIONAL } \\
\text { WILDLIFE REFUGE }\end{array}$ & Oyster Creek SET 01 & $\mathrm{NJ}$ & 5_Coastal_New_Jersey & USFWS & Back-barrier Lagoon Marsh \\
\hline $\begin{array}{l}\text { EDWIN B. FORSYTHE NATIONAL } \\
\text { WILDLIFE REFUGE }\end{array}$ & Motts/Mullica SET 01 & NJ & 5_Coastal_New_Jersey & USFWS & Back-barrier Lagoon Marsh \\
\hline $\begin{array}{l}\text { EDWIN B. FORSYTHE NATIONAL } \\
\text { WILDLIFE REFUGE }\end{array}$ & Motts/Mullica SET 02 & NJ & 5_Coastal_New_Jersey & USFWS & Back-barrier Lagoon Marsh \\
\hline $\begin{array}{l}\text { EDWIN B. FORSYTHE NATIONAL } \\
\text { WILDLIFE REFUGE }\end{array}$ & Motts/Mullica SET 03 & NJ & 5_Coastal_New_Jersey & USFWS & Back-barrier Lagoon Marsh \\
\hline $\begin{array}{l}\text { EDWIN B. FORSYTHE NATIONAL } \\
\text { WILDLIFE REFUGE }\end{array}$ & Motts/Mull. Wild SET 01 & NJ & 5_Coastal_New_Jersey & USFWS & Back-barrier Lagoon Marsh \\
\hline $\begin{array}{l}\text { EDWIN B. FORSYTHE NATIONAL } \\
\text { WILDLIFE REFUGE }\end{array}$ & Nacote Crk. Treat SET 02 & NJ & 5_Coastal_New_Jersey & USFWS & Back-barrier Lagoon Marsh \\
\hline $\begin{array}{l}\text { EDWIN B. FORSYTHE NATIONAL } \\
\text { WILDLIFE REFUGE }\end{array}$ & Nacote Crk. Treat SET 03 & NJ & 5_Coastal_New_Jersey & USFWS & Back-barrier Lagoon Marsh \\
\hline $\begin{array}{l}\text { EDWIN B. FORSYTHE NATIONAL } \\
\text { WILDLIFE REFUGE }\end{array}$ & Motts/Mull. Wild SET 03 & NJ & 5_Coastal_New_Jersey & USFWS & Back-barrier Lagoon Marsh \\
\hline $\begin{array}{l}\text { EDWIN B. FORSYTHE NATIONAL } \\
\text { WILDLIFE REFUGE }\end{array}$ & Motts/Mull. Wild SET 02 & NJ & 5_Coastal_New_Jersey & USFWS & Back-barrier Lagoon Marsh \\
\hline $\begin{array}{l}\text { EDWIN B. FORSYTHE NATIONAL } \\
\text { WILDLIFE REFUGE }\end{array}$ & Nacote Crk. Treat SET 01 & NJ & 5_Coastal_New_Jersey & USFWS & Back-barrier Lagoon Marsh \\
\hline
\end{tabular}


Table 2.1. Surface elevation table-marker horizon (SET-MH) data.-Continued

\begin{tabular}{|c|c|c|c|c|c|}
\hline SET_Geographical_Location & Site & State & Sub_Region & Partner & Broad_Geomophic_Setting \\
\hline $\begin{array}{l}\text { EDWIN B. FORSYTHE NATIONAL } \\
\text { WILDLIFE REFUGE }\end{array}$ & Parkertown SET 02 & NJ & 5_Coastal_New_Jersey & USFWS & Back-barrier Lagoon Marsh \\
\hline $\begin{array}{l}\text { EDWIN B. FORSYTHE NATIONAL } \\
\text { WILDLIFE REFUGE }\end{array}$ & West Creek & NJ & 5_Coastal_New_Jersey & USFWS & Back-barrier Lagoon Marsh \\
\hline $\begin{array}{l}\text { EDWIN B. FORSYTHE NATIONAL } \\
\text { WILDLIFE REFUGE }\end{array}$ & West Creek & $\mathrm{NJ}$ & 5_Coastal_New_Jersey & USFWS & Back-barrier Lagoon Marsh \\
\hline $\begin{array}{l}\text { EDWIN B. FORSYTHE NATIONAL } \\
\text { WILDLIFE REFUGE }\end{array}$ & West Creek & NJ & 5_Coastal_New_Jersey & USFWS & Back-barrier Lagoon Marsh \\
\hline $\begin{array}{l}\text { EDWIN B. FORSYTHE NATIONAL } \\
\text { WILDLIFE REFUGE }\end{array}$ & Parkertown SET 01 & NJ & 5_Coastal_New_Jersey & USFWS & Back-barrier Lagoon Marsh \\
\hline $\begin{array}{l}\text { EDWIN B. FORSYTHE NATIONAL } \\
\text { WILDLIFE REFUGE }\end{array}$ & Dinner 02 & NJ & 5_Coastal_New_Jersey & USFWS & Back-barrier Lagoon Marsh \\
\hline $\begin{array}{l}\text { EDWIN B. FORSYTHE NATIONAL } \\
\text { WILDLIFE REFUGE }\end{array}$ & Dinner 03 & NJ & 5_Coastal_New_Jersey & USFWS & Back-barrier Lagoon Marsh \\
\hline $\begin{array}{l}\text { EDWIN B. FORSYTHE NATIONAL } \\
\text { WILDLIFE REFUGE }\end{array}$ & Mill Crk-Cedar Run SET Purple* & NJ & 5_Coastal_New_Jersey & USFWS & Back-barrier Lagoon Marsh \\
\hline $\begin{array}{l}\text { EDWIN B. FORSYTHE NATIONAL } \\
\text { WILDLIFE REFUGE }\end{array}$ & Mill Crk-Cedar Run SET Yellow* & NJ & 5_Coastal_New_Jersey & USFWS & Back-barrier Lagoon Marsh \\
\hline $\begin{array}{l}\text { EDWIN B. FORSYTHE NATIONAL } \\
\text { WILDLIFE REFUGE }\end{array}$ & Mill Crk-Cedar Run SET Green * & NJ & 5_Coastal_New_Jersey & USFWS & Back-barrier Lagoon Marsh \\
\hline $\begin{array}{l}\text { EDWIN B. FORSYTHE NATIONAL } \\
\text { WILDLIFE REFUGE }\end{array}$ & Mill Crk-Cedar Run SET Purple* & NJ & 5_Coastal_New_Jersey & USFWS & Back-barrier Lagoon Marsh \\
\hline $\begin{array}{l}\text { EDWIN B. FORSYTHE NATIONAL } \\
\text { WILDLIFE REFUGE }\end{array}$ & Mill Crk-Cedar Run SET Purple* & NJ & 5_Coastal_New_Jersey & USFWS & Back-barrier Lagoon Marsh \\
\hline $\begin{array}{l}\text { EDWIN B. FORSYTHE NATIONAL } \\
\text { WILDLIFE REFUGE }\end{array}$ & Cedar Run Dock SET 02 & NJ & 5_Coastal_New_Jersey & USFWS & Back-barrier Lagoon Marsh \\
\hline $\begin{array}{l}\text { EDWIN B. FORSYTHE NATIONAL } \\
\text { WILDLIFE REFUGE }\end{array}$ & Mill Crk-Cedar Run SET Green * & NJ & 5_Coastal_New_Jersey & USFWS & Back-barrier Lagoon Marsh \\
\hline $\begin{array}{l}\text { EDWIN B. FORSYTHE NATIONAL } \\
\text { WILDLIFE REFUGE }\end{array}$ & Mill Crk-Cedar Run SET Yellow* & NJ & 5_Coastal_New_Jersey & USFWS & Back-barrier Lagoon Marsh \\
\hline $\begin{array}{l}\text { EDWIN B. FORSYTHE NATIONAL } \\
\text { WILDLIFE REFUGE }\end{array}$ & Mill Crk-Cedar Run SET Green * & NJ & 5_Coastal_New_Jersey & USFWS & Back-barrier Lagoon Marsh \\
\hline $\begin{array}{l}\text { EDWIN B. FORSYTHE NATIONAL } \\
\text { WILDLIFE REFUGE }\end{array}$ & Cedar Run 01 & NJ & 5_Coastal_New_Jersey & USFWS & Back-barrier Lagoon Marsh \\
\hline $\begin{array}{l}\text { EDWIN B. FORSYTHE NATIONAL } \\
\text { WILDLIFE REFUGE }\end{array}$ & Cedar Run 02 & NJ & 5_Coastal_New_Jersey & USFWS & Back-barrier Lagoon Marsh \\
\hline
\end{tabular}


Table 2.1. Surface elevation table-marker horizon (SET-MH) data.-Continued

\begin{tabular}{|c|c|c|c|c|c|}
\hline SET_Geographical_Location & Site & State & Sub_Region & Partner & Broad_Geomophic_Setting \\
\hline $\begin{array}{l}\text { EDWIN B. FORSYTHE NATIONAL } \\
\text { WILDLIFE REFUGE }\end{array}$ & Cedar Run 03 & NJ & 5_Coastal_New_Jersey & USFWS & Back-barrier Lagoon Marsh \\
\hline $\begin{array}{l}\text { EDWIN B. FORSYTHE NATIONAL } \\
\text { WILDLIFE REFUGE }\end{array}$ & AT\&T 03 & NJ & 5_Coastal_New_Jersey & USFWS & Back-barrier Lagoon Marsh \\
\hline $\begin{array}{l}\text { EDWIN B. FORSYTHE NATIONAL } \\
\text { WILDLIFE REFUGE }\end{array}$ & AT\&T 02 & NJ & 5_Coastal_New_Jersey & USFWS & Back-barrier Lagoon Marsh \\
\hline $\begin{array}{l}\text { EDWIN B. FORSYTHE NATIONAL } \\
\text { WILDLIFE REFUGE }\end{array}$ & AT\&T (New) SET 03 & NJ & 5_Coastal_New_Jersey & USFWS & Back-barrier Lagoon Marsh \\
\hline $\begin{array}{l}\text { EDWIN B. FORSYTHE NATIONAL } \\
\text { WILDLIFE REFUGE }\end{array}$ & AT\&T (New) SET 02 & NJ & 5_Coastal_New_Jersey & USFWS & Back-barrier Lagoon Marsh \\
\hline $\begin{array}{l}\text { EDWIN B. FORSYTHE NATIONAL } \\
\text { WILDLIFE REFUGE }\end{array}$ & AT\&T 01 & NJ & 5_Coastal_New_Jersey & USFWS & Back-barrier Lagoon Marsh \\
\hline $\begin{array}{l}\text { EDWIN B. FORSYTHE NATIONAL } \\
\text { WILDLIFE REFUGE }\end{array}$ & AT\&T (New) SET 01 & NJ & 5_Coastal_New_Jersey & USFWS & Back-barrier Lagoon Marsh \\
\hline $\begin{array}{l}\text { EDWIN B. FORSYTHE NATIONAL } \\
\text { WILDLIFE REFUGE }\end{array}$ & Forked River 05 & NJ & 5_Coastal_New_Jersey & USFWS & Back-barrier Lagoon Marsh \\
\hline $\begin{array}{l}\text { EDWIN B. FORSYTHE NATIONAL } \\
\text { WILDLIFE REFUGE }\end{array}$ & Forked River 03 & NJ & 5_Coastal_New_Jersey & USFWS & Back-barrier Lagoon Marsh \\
\hline $\begin{array}{l}\text { EDWIN B. FORSYTHE NATIONAL } \\
\text { WILDLIFE REFUGE }\end{array}$ & Forked River 06 & NJ & 5_Coastal_New_Jersey & USFWS & Back-barrier Lagoon Marsh \\
\hline $\begin{array}{l}\text { EDWIN B. FORSYTHE NATIONAL } \\
\text { WILDLIFE REFUGE }\end{array}$ & Forked River 04 & NJ & 5_Coastal_New_Jersey & USFWS & Back-barrier Lagoon Marsh \\
\hline $\begin{array}{l}\text { EDWIN B. FORSYTHE NATIONAL } \\
\text { WILDLIFE REFUGE }\end{array}$ & Ocean Gate 01 & NJ & 5_Coastal_New_Jersey & USFWS & Back-barrier Lagoon Marsh \\
\hline $\begin{array}{l}\text { EDWIN B. FORSYTHE NATIONAL } \\
\text { WILDLIFE REFUGE }\end{array}$ & Ocean Gate 03 & NJ & 5_Coastal_New_Jersey & USFWS & Back-barrier Lagoon Marsh \\
\hline $\begin{array}{l}\text { EDWIN B. FORSYTHE NATIONAL } \\
\text { WILDLIFE REFUGE }\end{array}$ & Ocean Gate 02 & NJ & 5_Coastal_New_Jersey & USFWS & Back-barrier Lagoon Marsh \\
\hline $\begin{array}{l}\text { EDWIN B. FORSYTHE NATIONAL } \\
\text { WILDLIFE REFUGE }\end{array}$ & Good Luck Point 02 & NJ & 5_Coastal_New_Jersey & USFWS & Back-barrier Lagoon Marsh \\
\hline $\begin{array}{l}\text { EDWIN B. FORSYTHE NATIONAL } \\
\text { WILDLIFE REFUGE }\end{array}$ & Good Luck Point 03 & NJ & 5_Coastal_New_Jersey & USFWS & Back-barrier Lagoon Marsh \\
\hline $\begin{array}{l}\text { EDWIN B. FORSYTHE NATIONAL } \\
\text { WILDLIFE REFUGE }\end{array}$ & Good Luck Point 01 & NJ & 5_Coastal_New_Jersey & USFWS & Back-barrier Lagoon Marsh \\
\hline $\begin{array}{l}\text { EDWIN B. FORSYTHE NATIONAL } \\
\text { WILDLIFE REFUGE }\end{array}$ & Mandolay 03 & NJ & 5_Coastal_New_Jersey & USFWS & Back-barrier Lagoon Marsh \\
\hline
\end{tabular}


Table 2.1. Surface elevation table-marker horizon (SET-MH) data.-Continued

\begin{tabular}{|c|c|c|c|c|c|}
\hline SET_Geographical_Location & Site & State & Sub_Region & Partner & Broad_Geomophic_Setting \\
\hline $\begin{array}{l}\text { EDWIN B. FORSYTHE NATIONAL } \\
\text { WILDLIFE REFUGE }\end{array}$ & Mandolay 01 & NJ & 5_Coastal_New_Jersey & USFWS & Back-barrier Lagoon Marsh \\
\hline $\begin{array}{l}\text { EDWIN B. FORSYTHE NATIONAL } \\
\text { WILDLIFE REFUGE }\end{array}$ & Mandolay 02 & NJ & 5_Coastal_New_Jersey & USFWS & Back-barrier Lagoon Marsh \\
\hline $\begin{array}{l}\text { EDWIN B. FORSYTHE NATIONAL } \\
\text { WILDLIFE REFUGE }\end{array}$ & Reedy Creek & NJ & 5_Coastal_New_Jersey & USFWS & Back-barrier Lagoon Marsh \\
\hline $\begin{array}{l}\text { EDWIN B. FORSYTHE NATIONAL } \\
\text { WILDLIFE REFUGE }\end{array}$ & Reedy Creek & NJ & 5_Coastal_New_Jersey & USFWS & Back-barrier Lagoon Marsh \\
\hline $\begin{array}{l}\text { EDWIN B. FORSYTHE NATIONAL } \\
\text { WILDLIFE REFUGE }\end{array}$ & Reedy Creek & NJ & 5_Coastal_New_Jersey & USFWS & Back-barrier Lagoon Marsh \\
\hline $\begin{array}{l}\text { EDWIN B. FORSYTHE NATIONAL } \\
\text { WILDLIFE REFUGE }\end{array}$ & Metedeconk & NJ & 5_Coastal_New_Jersey & USFWS & Back-barrier Lagoon Marsh \\
\hline $\begin{array}{l}\text { EDWIN B. FORSYTHE NATIONAL } \\
\text { WILDLIFE REFUGE }\end{array}$ & Metedeconk & NJ & 5_Coastal_New_Jersey & USFWS & Back-barrier Lagoon Marsh \\
\hline $\begin{array}{l}\text { EDWIN B. FORSYTHE NATIONAL } \\
\text { WILDLIFE REFUGE }\end{array}$ & Metedeconk & NJ & 5_Coastal_New_Jersey & USFWS & Back-barrier Lagoon Marsh \\
\hline $\begin{array}{l}\text { EDWIN B. FORSYTHE NATIONAL } \\
\text { WILDLIFE REFUGE }\end{array}$ & Metedeconk & NJ & 5_Coastal_New_Jersey & USFWS & Back-barrier Lagoon Marsh \\
\hline $\begin{array}{l}\text { EDWIN B. FORSYTHE NATIONAL } \\
\text { WILDLIFE REFUGE }\end{array}$ & Metedeconk & NJ & 5_Coastal_New_Jersey & USFWS & Back-barrier Lagoon Marsh \\
\hline $\begin{array}{l}\text { EDWIN B. FORSYTHE NATIONAL } \\
\text { WILDLIFE REFUGE }\end{array}$ & Metedeconk & NJ & 5_Coastal_New_Jersey & USFWS & Back-barrier Lagoon Marsh \\
\hline Forsythe, New Jersey & Little.Beach & NJ & 5_Coastal_New_Jersey & USFWS & \\
\hline Forsythe, New Jersey & Little.Beach & NJ & 5_Coastal_New_Jersey & USFWS & \\
\hline Forsythe, New Jersey & Little.Beach & NJ & 5_Coastal_New_Jersey & USFWS & \\
\hline Forsythe, New Jersey & Little.Beach & NJ & 5_Coastal_New_Jersey & USFWS & \\
\hline Forsythe, New Jersey & Little.Beach & NJ & 5_Coastal_New_Jersey & USFWS & \\
\hline Forsythe, New Jersey & Little.Beach & NJ & 5_Coastal_New_Jersey & USFWS & \\
\hline Forsythe NWR & ATT & NJ & 5_Coastal_New_Jersey & USFWS & \\
\hline
\end{tabular}


Table 2.1. Surface elevation table-marker horizon (SET-MH) data.-Continued

\begin{tabular}{|c|c|c|c|c|c|}
\hline SET_Geographical_Location & Site & State & Sub_Region & Partner & Broad_Geomophic_Setting \\
\hline Forsythe NWR & ATT & NJ & 5_Coastal_New_Jersey & USFWS & \\
\hline Forsythe NWR & ATT & $\mathrm{NJ}$ & 5_Coastal_New_Jersey & USFWS & \\
\hline Forsythe NWR & ATT & NJ & 5_Coastal_New_Jersey & USFWS & \\
\hline Forsythe NWR & ATT & NJ & 5_Coastal_New_Jersey & USFWS & \\
\hline Forsythe NWR & ATT & NJ & 5_Coastal_New_Jersey & USFWS & \\
\hline $\begin{array}{l}\text { EDWIN B. FORSYTHE NATIONAL } \\
\text { WILDLIFE REFUGE }\end{array}$ & Horse Point & NJ & 5_Coastal_New_Jersey & & Back-barrier Lagoon Marsh \\
\hline $\begin{array}{l}\text { EDWIN B. FORSYTHE NATIONAL } \\
\text { WILDLIFE REFUGE }\end{array}$ & Horse Point & NJ & 5_Coastal_New_Jersey & & Back-barrier Lagoon Marsh \\
\hline $\begin{array}{l}\text { EDWIN B. FORSYTHE NATIONAL } \\
\text { WILDLIFE REFUGE }\end{array}$ & Horse Point & NJ & 5_Coastal_New_Jersey & & Back-barrier Lagoon Marsh \\
\hline Delaware NERR (St Jones Component) & Impoundment & $\mathrm{DE}$ & 6_Delaware_Bay & NERR & \\
\hline Delaware NERR (St Jones Component) & Boardwalk & $\mathrm{DE}$ & 6_Delaware_Bay & NERR & \\
\hline Delaware NERR (St Jones Component) & Wildcat & $\mathrm{DE}$ & 6_Delaware_Bay & NERR & \\
\hline Delaware NERR (St Jones Component) & Upstream Isaacs Branch & $\mathrm{DE}$ & 6_Delaware_Bay & NERR & \\
\hline $\begin{array}{l}\text { Delaware NERR (Blackbird Creek } \\
\text { Component) }\end{array}$ & Blackbird Landing Road & $\mathrm{DE}$ & 6_Delaware_Bay & NERR & \\
\hline $\begin{array}{l}\text { Delaware NERR (Blackbird Creek } \\
\text { Component) }\end{array}$ & Delon & $\mathrm{DE}$ & 6_Delaware_Bay & NERR & \\
\hline $\begin{array}{l}\text { Delaware NERR (Blackbird Creek } \\
\text { Component) }\end{array}$ & Eagle's Nest & DE & 6_Delaware_Bay & NERR & \\
\hline $\begin{array}{l}\text { Delaware NERR (Blackbird Creek } \\
\text { Component) }\end{array}$ & Beaver Branch & $\mathrm{DE}$ & 6_Delaware_Bay & NERR & \\
\hline Delaware NERR (St Jones Component) & Reserve.Ditch & $\mathrm{DE}$ & 6_Delaware_Bay & NERR & \\
\hline Delaware NERR (St Jones Component) & Trail & $\mathrm{DE}$ & 6_Delaware_Bay & NERR & \\
\hline
\end{tabular}


Table 2.1. Surface elevation table-marker horizon (SET-MH) data.-Continued

\begin{tabular}{|c|c|c|c|c|c|}
\hline SET_Geographical_Location & Site & State & Sub_Region & Partner & Broad_Geomophic_Setting \\
\hline Dennis, NJ (Delaware Bay) & Dennis Creek & NJ & 6_Delaware_Bay & Other & Estuarine Embayment \\
\hline Dennis, NJ (Delaware Bay) & Dennis Creek & NJ & 6_Delaware_Bay & Other & Estuarine Embayment \\
\hline Dennis, NJ (Delaware Bay) & Dennis Creek & NJ & 6_Delaware_Bay & Other & Estuarine Embayment \\
\hline Downe, NJ (Delaware Bay) & Dividing Creek & NJ & 6_Delaware_Bay & Other & Estuarine Embayment \\
\hline Downe, NJ (Delaware Bay) & Dividing Creek & NJ & 6_Delaware_Bay & Other & Estuarine Embayment \\
\hline Downe, NJ (Delaware Bay) & Dividing Creek & NJ & 6_Delaware_Bay & Other & Estuarine Embayment \\
\hline Bivalve, NJ (Delaware Bay) & Maurice River & NJ & 6_Delaware_Bay & Other & Estuarine Embayment \\
\hline Bivalve, NJ (Delaware Bay) & Maurice River & NJ & 6_Delaware_Bay & Other & Estuarine Embayment \\
\hline Bivalve, NJ (Delaware Bay) & Maurice River & NJ & 6_Delaware_Bay & Other & Estuarine Embayment \\
\hline $\begin{array}{l}\text { PRIME HOOK NATIONAL WILDLIFE } \\
\text { REFUGE }\end{array}$ & SET_IV_03 & $\mathrm{DE}$ & 6_Delaware_Bay & USFWS & Estuarine Embayment \\
\hline $\begin{array}{l}\text { PRIME HOOK NATIONAL WILDLIFE } \\
\text { REFUGE }\end{array}$ & SET_IV_02 & $\mathrm{DE}$ & 6_Delaware_Bay & USFWS & Estuarine Embayment \\
\hline $\begin{array}{l}\text { PRIME HOOK NATIONAL WILDLIFE } \\
\text { REFUGE }\end{array}$ & SET_IV_01 & $\mathrm{DE}$ & 6_Delaware_Bay & USFWS & Estuarine Embayment \\
\hline $\begin{array}{l}\text { PRIME HOOK NATIONAL WILDLIFE } \\
\text { REFUGE }\end{array}$ & PH2-6 (Deep) & $\mathrm{DE}$ & 6_Delaware_Bay & USFWS & Estuarine Embayment \\
\hline $\begin{array}{l}\text { PRIME HOOK NATIONAL WILDLIFE } \\
\text { REFUGE }\end{array}$ & PH2-5 (Deep) & $\mathrm{DE}$ & 6_Delaware_Bay & USFWS & Estuarine Embayment \\
\hline $\begin{array}{l}\text { PRIME HOOK NATIONAL WILDLIFE } \\
\text { REFUGE }\end{array}$ & PH2-4 (Deep) & $\mathrm{DE}$ & 6_Delaware_Bay & USFWS & Estuarine Embayment \\
\hline $\begin{array}{l}\text { PRIME HOOK NATIONAL WILDLIFE } \\
\text { REFUGE }\end{array}$ & PH2-3 (Deep) & $\mathrm{DE}$ & 6_Delaware_Bay & USFWS & Estuarine Embayment \\
\hline $\begin{array}{l}\text { PRIME HOOK NATIONAL WILDLIFE } \\
\text { REFUGE }\end{array}$ & PH2-2 (Deep) & $\mathrm{DE}$ & 6_Delaware_Bay & USFWS & Estuarine Embayment \\
\hline $\begin{array}{l}\text { PRIME HOOK NATIONAL WILDLIFE } \\
\text { REFUGE }\end{array}$ & PH2-1 (Deep) & $\mathrm{DE}$ & 6_Delaware_Bay & USFWS & Estuarine Embayment \\
\hline
\end{tabular}


Table 2.1. Surface elevation table-marker horizon (SET-MH) data.-Continued

\begin{tabular}{|c|c|c|c|c|c|}
\hline SET_Geographical_Location & Site & State & Sub_Region & Partner & Broad_Geomophic_Setting \\
\hline $\begin{array}{l}\text { PRIME HOOK NATIONAL WILDLIFE } \\
\text { REFUGE }\end{array}$ & Set 2 (Deep) & $\mathrm{DE}$ & 6_Delaware_Bay & USFWS & Estuarine Embayment \\
\hline $\begin{array}{l}\text { PRIME HOOK NATIONAL WILDLIFE } \\
\text { REFUGE }\end{array}$ & Set 1 (Deep) & $\mathrm{DE}$ & 6_Delaware_Bay & USFWS & Estuarine Embayment \\
\hline $\begin{array}{l}\text { CAPE MAY NATIONAL WILDLIFE } \\
\text { REFUGE }\end{array}$ & Sunray03 & NJ & 6_Delaware_Bay & USFWS & Estuarine Embayment \\
\hline $\begin{array}{l}\text { CAPE MAY NATIONAL WILDLIFE } \\
\text { REFUGE }\end{array}$ & Sunray02 & NJ & 6_Delaware_Bay & USFWS & Estuarine Embayment \\
\hline $\begin{array}{l}\text { CAPE MAY NATIONAL WILDLIFE } \\
\text { REFUGE }\end{array}$ & Sunray01 & NJ & 6_Delaware_Bay & USFWS & Estuarine Embayment \\
\hline $\begin{array}{l}\text { CAPE MAY NATIONAL WILDLIFE } \\
\text { REFUGE }\end{array}$ & Delhaven03 & NJ & 6_Delaware_Bay & USFWS & Estuarine Embayment \\
\hline $\begin{array}{l}\text { CAPE MAY NATIONAL WILDLIFE } \\
\text { REFUGE }\end{array}$ & Delhaven02 & NJ & 6_Delaware_Bay & USFWS & Estuarine Embayment \\
\hline $\begin{array}{l}\text { CAPE MAY NATIONAL WILDLIFE } \\
\text { REFUGE }\end{array}$ & Delhaven01 & NJ & 6_Delaware_Bay & USFWS & Estuarine Embayment \\
\hline $\begin{array}{l}\text { CAPE MAY NATIONAL WILDLIFE } \\
\text { REFUGE }\end{array}$ & Green Creek 03 & NJ & 6_Delaware_Bay & USFWS & Estuarine Embayment \\
\hline $\begin{array}{l}\text { CAPE MAY NATIONAL WILDLIFE } \\
\text { REFUGE }\end{array}$ & Green Creek 01 & NJ & 6_Delaware_Bay & USFWS & Estuarine Embayment \\
\hline $\begin{array}{l}\text { CAPE MAY NATIONAL WILDLIFE } \\
\text { REFUGE }\end{array}$ & Green Creek 02 & NJ & 6_Delaware_Bay & USFWS & Estuarine Embayment \\
\hline $\begin{array}{l}\text { CAPE MAY NATIONAL WILDLIFE } \\
\text { REFUGE }\end{array}$ & Dias Headwaters 03 & NJ & 6_Delaware_Bay & USFWS & Estuarine Embayment \\
\hline $\begin{array}{l}\text { CAPE MAY NATIONAL WILDLIFE } \\
\text { REFUGE }\end{array}$ & Dias Headwaters 02 & NJ & 6_Delaware_Bay & USFWS & Estuarine Embayment \\
\hline $\begin{array}{l}\text { CAPE MAY NATIONAL WILDLIFE } \\
\text { REFUGE }\end{array}$ & Dias Headwaters 01 & NJ & 6_Delaware_Bay & USFWS & Estuarine Embayment \\
\hline $\begin{array}{l}\text { CAPE MAY NATIONAL WILDLIFE } \\
\text { REFUGE }\end{array}$ & Dias Creek01 & NJ & 6_Delaware_Bay & USFWS & Estuarine Embayment \\
\hline $\begin{array}{l}\text { CAPE MAY NATIONAL WILDLIFE } \\
\text { REFUGE }\end{array}$ & Dias Creek02 & NJ & 6_Delaware_Bay & USFWS & Estuarine Embayment \\
\hline $\begin{array}{l}\text { CAPE MAY NATIONAL WILDLIFE } \\
\text { REFUGE }\end{array}$ & Dias Creek03 & NJ & 6_Delaware_Bay & USFWS & Estuarine Embayment \\
\hline $\begin{array}{l}\text { CAPE MAY NATIONAL WILDLIFE } \\
\text { REFUGE }\end{array}$ & Bidwells Headwaters03 & NJ & 6_Delaware_Bay & USFWS & Estuarine Embayment \\
\hline
\end{tabular}


Table 2.1. Surface elevation table-marker horizon (SET-MH) data.-Continued

\begin{tabular}{|c|c|c|c|c|c|}
\hline SET_Geographical_Location & Site & State & Sub_Region & Partner & Broad_Geomophic_Setting \\
\hline $\begin{array}{l}\text { CAPE MAY NATIONAL WILDLIFE } \\
\text { REFUGE }\end{array}$ & Reeds Beach01 & NJ & 6_Delaware_Bay & USFWS & Estuarine Embayment \\
\hline $\begin{array}{l}\text { CAPE MAY NATIONAL WILDLIFE } \\
\text { REFUGE }\end{array}$ & Bidwells Headwaters02 & NJ & 6_Delaware_Bay & USFWS & Estuarine Embayment \\
\hline $\begin{array}{l}\text { CAPE MAY NATIONAL WILDLIFE } \\
\text { REFUGE }\end{array}$ & Reeds Beach02 & NJ & 6_Delaware_Bay & USFWS & Estuarine Embayment \\
\hline $\begin{array}{l}\text { CAPE MAY NATIONAL WILDLIFE } \\
\text { REFUGE }\end{array}$ & Reeds Beach04 & NJ & 6_Delaware_Bay & USFWS & Estuarine Embayment \\
\hline $\begin{array}{l}\text { CAPE MAY NATIONAL WILDLIFE } \\
\text { REFUGE }\end{array}$ & Bidwells Headwaters01 & NJ & 6_Delaware_Bay & USFWS & Estuarine Embayment \\
\hline $\begin{array}{l}\text { CAPE MAY NATIONAL WILDLIFE } \\
\text { REFUGE }\end{array}$ & Reeds Beach03 & NJ & 6_Delaware_Bay & USFWS & Estuarine Embayment \\
\hline $\begin{array}{l}\text { BOMBAY HOOK NATIONAL WILDLIFE } \\
\text { REFUGE }\end{array}$ & SET03_AF & $\mathrm{DE}$ & 6_Delaware_Bay & USFWS & Estuarine Embayment \\
\hline $\begin{array}{l}\text { BOMBAY HOOK NATIONAL WILDLIFE } \\
\text { REFUGE }\end{array}$ & SET03_KELL & $\mathrm{DE}$ & 6_Delaware_Bay & USFWS & Estuarine Embayment \\
\hline $\begin{array}{l}\text { BOMBAY HOOK NATIONAL WILDLIFE } \\
\text { REFUGE }\end{array}$ & SET02_AF & $\mathrm{DE}$ & 6_Delaware_Bay & USFWS & Estuarine Embayment \\
\hline $\begin{array}{l}\text { BOMBAY HOOK NATIONAL WILDLIFE } \\
\text { REFUGE }\end{array}$ & SET01_AF & $\mathrm{DE}$ & 6_Delaware_Bay & USFWS & Estuarine Embayment \\
\hline $\begin{array}{l}\text { BOMBAY HOOK NATIONAL WILDLIFE } \\
\text { REFUGE }\end{array}$ & SB03 & $\mathrm{DE}$ & 6_Delaware_Bay & USFWS & Estuarine Embayment \\
\hline $\begin{array}{l}\text { BOMBAY HOOK NATIONAL WILDLIFE } \\
\text { REFUGE }\end{array}$ & SET02_KELL & $\mathrm{DE}$ & 6_Delaware_Bay & USFWS & Estuarine Embayment \\
\hline $\begin{array}{l}\text { BOMBAY HOOK NATIONAL WILDLIFE } \\
\text { REFUGE }\end{array}$ & SB02 & $\mathrm{DE}$ & 6_Delaware_Bay & USFWS & Estuarine Embayment \\
\hline $\begin{array}{l}\text { BOMBAY HOOK NATIONAL WILDLIFE } \\
\text { REFUGE }\end{array}$ & SET01_KELL & $\mathrm{DE}$ & 6_Delaware_Bay & USFWS & Estuarine Embayment \\
\hline $\begin{array}{l}\text { BOMBAY HOOK NATIONAL WILDLIFE } \\
\text { REFUGE }\end{array}$ & SB01 & $\mathrm{DE}$ & 6_Delaware_Bay & USFWS & Estuarine Embayment \\
\hline $\begin{array}{l}\text { BOMBAY HOOK NATIONAL WILDLIFE } \\
\text { REFUGE }\end{array}$ & SET03_Kent & $\mathrm{DE}$ & 6_Delaware_Bay & USFWS & Estuarine Embayment \\
\hline $\begin{array}{l}\text { BOMBAY HOOK NATIONAL WILDLIFE } \\
\text { REFUGE }\end{array}$ & SET01_Kent & $\mathrm{DE}$ & 6_Delaware_Bay & USFWS & Estuarine Embayment \\
\hline $\begin{array}{l}\text { BOMBAY HOOK NATIONAL WILDLIFE } \\
\text { REFUGE }\end{array}$ & SET02_Kent & DE & 6_Delaware_Bay & USFWS & Estuarine Embayment \\
\hline
\end{tabular}


Table 2.1. Surface elevation table-marker horizon (SET-MH) data.-Continued

\begin{tabular}{|c|c|c|c|c|c|}
\hline SET_Geographical_Location & Site & State & Sub_Region & Partner & Broad_Geomophic_Setting \\
\hline $\begin{array}{l}\text { BOMBAY HOOK NATIONAL WILDLIFE } \\
\text { REFUGE }\end{array}$ & Set03-BHIS & $\mathrm{DE}$ & 6_Delaware_Bay & USFWS & Estuarine Embayment \\
\hline $\begin{array}{l}\text { BOMBAY HOOK NATIONAL WILDLIFE } \\
\text { REFUGE }\end{array}$ & SET02_GI & $\mathrm{DE}$ & 6_Delaware_Bay & USFWS & Estuarine Embayment \\
\hline $\begin{array}{l}\text { BOMBAY HOOK NATIONAL WILDLIFE } \\
\text { REFUGE }\end{array}$ & SET01_GI & $\mathrm{DE}$ & 6_Delaware_Bay & USFWS & Estuarine Embayment \\
\hline $\begin{array}{l}\text { BOMBAY HOOK NATIONAL WILDLIFE } \\
\text { REFUGE }\end{array}$ & Set01-BHIS & $\mathrm{DE}$ & 6_Delaware_Bay & USFWS & Estuarine Embayment \\
\hline $\begin{array}{l}\text { BOMBAY HOOK NATIONAL WILDLIFE } \\
\text { REFUGE }\end{array}$ & SET03_GI & $\mathrm{DE}$ & 6_Delaware_Bay & USFWS & Estuarine Embayment \\
\hline $\begin{array}{l}\text { BOMBAY HOOK NATIONAL WILDLIFE } \\
\text { REFUGE }\end{array}$ & Set02-BHIS & $\mathrm{DE}$ & 6_Delaware_Bay & USFWS & Estuarine Embayment \\
\hline $\begin{array}{l}\text { BOMBAY HOOK NATIONAL WILDLIFE } \\
\text { REFUGE }\end{array}$ & SET01_BHIN & $\mathrm{DE}$ & 6_Delaware_Bay & USFWS & Estuarine Embayment \\
\hline $\begin{array}{l}\text { BOMBAY HOOK NATIONAL WILDLIFE } \\
\text { REFUGE }\end{array}$ & SET02_BHIN_Redo & $\mathrm{DE}$ & 6_Delaware_Bay & USFWS & Estuarine Embayment \\
\hline $\begin{array}{l}\text { BOMBAY HOOK NATIONAL WILDLIFE } \\
\text { REFUGE }\end{array}$ & Set01_LTHB & $\mathrm{DE}$ & 6_Delaware_Bay & USFWS & Estuarine Embayment \\
\hline $\begin{array}{l}\text { BOMBAY HOOK NATIONAL WILDLIFE } \\
\text { REFUGE }\end{array}$ & SET03_BHIN & $\mathrm{DE}$ & 6_Delaware_Bay & USFWS & Estuarine Embayment \\
\hline $\begin{array}{l}\text { BOMBAY HOOK NATIONAL WILDLIFE } \\
\text { REFUGE }\end{array}$ & SET03_LTHB & $\mathrm{DE}$ & 6_Delaware_Bay & USFWS & Estuarine Embayment \\
\hline $\begin{array}{l}\text { BOMBAY HOOK NATIONAL WILDLIFE } \\
\text { REFUGE }\end{array}$ & SET02_LTHB & $\mathrm{DE}$ & 6_Delaware_Bay & USFWS & Estuarine Embayment \\
\hline $\begin{array}{l}\text { BOMBAY HOOK NATIONAL WILDLIFE } \\
\text { REFUGE }\end{array}$ & SET04_LTHB & $\mathrm{DE}$ & 6_Delaware_Bay & USFWS & Estuarine Embayment \\
\hline $\begin{array}{l}\text { SUPAWNA MEADOWS NATIONAL } \\
\text { WILDLIFE REFUGE }\end{array}$ & Bald02 & NJ & 6_Delaware_Bay & USFWS & Estuarine Embayment \\
\hline $\begin{array}{l}\text { SUPAWNA MEADOWS NATIONAL } \\
\text { WILDLIFE REFUGE }\end{array}$ & Bald03 & NJ & 6_Delaware_Bay & USFWS & Estuarine Embayment \\
\hline $\begin{array}{l}\text { SUPAWNA MEADOWS NATIONAL } \\
\text { WILDLIFE REFUGE }\end{array}$ & Bald01 & NJ & 6_Delaware_Bay & USFWS & Estuarine Embayment \\
\hline $\begin{array}{l}\text { SUPAWNA MEADOWS NATIONAL } \\
\text { WILDLIFE REFUGE }\end{array}$ & Mud01 & NJ & 6_Delaware_Bay & USFWS & Estuarine Embayment \\
\hline $\begin{array}{l}\text { SUPAWNA MEADOWS NATIONAL } \\
\text { WILDLIFE REFUGE }\end{array}$ & Mud03 & NJ & 6_Delaware_Bay & USFWS & Estuarine Embayment \\
\hline
\end{tabular}


Table 2.1. Surface elevation table-marker horizon (SET-MH) data.-Continued

\begin{tabular}{|c|c|c|c|c|c|}
\hline SET_Geographical_Location & Site & State & Sub_Region & Partner & Broad_Geomophic_Setting \\
\hline $\begin{array}{l}\text { SUPAWNA MEADOWS NATIONAL } \\
\text { WILDLIFE REFUGE }\end{array}$ & Mud02 & NJ & 6_Delaware_Bay & USFWS & Estuarine Embayment \\
\hline $\begin{array}{l}\text { PRIME HOOK NATIONAL WILDLIFE } \\
\text { REFUGE }\end{array}$ & Set 3 (Deep) & $\mathrm{DE}$ & 6_Delaware_Bay & USFWS & Estuarine Embayment \\
\hline Bombay Hook NWR & Bombay.Hook & $\mathrm{DE}$ & 6_Delaware_Bay & USGS & Estuarine Embayment \\
\hline Bombay Hook NWR & Bombay.Hook & $\mathrm{DE}$ & 6_Delaware_Bay & USGS & Estuarine Embayment \\
\hline Bombay Hook NWR & Bombay.Hook & $\mathrm{DE}$ & 6_Delaware_Bay & USGS & Estuarine Embayment \\
\hline Bombay Hook NWR & Bombay.Hook & $\mathrm{DE}$ & 6_Delaware_Bay & USGS & Estuarine Embayment \\
\hline EA Vaughn & EA Vaughn_EAV1-ditched & $\mathrm{MD}$ & 7_Coastal_Delmarva & NERR & Back-barrier Lagoon Marsh \\
\hline EA Vaughn & EA Vaughn_EAV1-ditched & MD & 7_Coastal_Delmarva & NERR & Back-barrier Lagoon Marsh \\
\hline EA Vaughn & EA Vaughn_EAV1-ditched & MD & 7_Coastal_Delmarva & NERR & Back-barrier Lagoon Marsh \\
\hline EA Vaughn & EA Vaughn_EA V2-unditched & MD & 7_Coastal_Delmarva & NERR & Back-barrier Lagoon Marsh \\
\hline EA Vaughn & EA Vaughn_EA V2-unditched & MD & 7_Coastal_Delmarva & NERR & Back-barrier Lagoon Marsh \\
\hline EA Vaughn & EA Vaughn_EA V2-unditched & MD & 7_Coastal_Delmarva & NERR & Back-barrier Lagoon Marsh \\
\hline Assateague Island, MD & ASIS.Marsh.5 & MD & 7_Coastal_Delmarva & NPS & Back-barrier Lagoon Marsh \\
\hline Assateague Island, MD & ASIS.Marsh.5 & MD & 7_Coastal_Delmarva & NPS & Back-barrier Lagoon Marsh \\
\hline Assateague Island, MD & ASIS.Marsh.5 & MD & 7_Coastal_Delmarva & NPS & Back-barrier Lagoon Marsh \\
\hline Assateague Island, MD & ASIS.Marsh.5 & MD & 7_Coastal_Delmarva & NPS & Back-barrier Lagoon Marsh \\
\hline Assateague Island, MD & ASIS.Marsh. 8 & MD & 7_Coastal_Delmarva & NPS & Back-barrier Lagoon Marsh \\
\hline Assateague Island, MD & ASIS.Marsh. 8 & MD & 7_Coastal_Delmarva & NPS & Back-barrier Lagoon Marsh \\
\hline
\end{tabular}


Table 2.1. Surface elevation table-marker horizon (SET-MH) data.-Continued

\begin{tabular}{|c|c|c|c|c|c|}
\hline SET_Geographical_Location & Site & State & Sub_Region & Partner & Broad_Geomophic_Setting \\
\hline Assateague Island, MD & ASIS.Marsh.8 & MD & 7_Coastal_Delmarva & NPS & Back-barrier Lagoon Marsh \\
\hline Assateague Island, MD & ASIS.Marsh. 8 & MD & 7_Coastal_Delmarva & NPS & Back-barrier Lagoon Marsh \\
\hline Assateague Island, MD & ASIS.Marsh.6 & MD & 7_Coastal_Delmarva & NPS & Back-barrier Lagoon Marsh \\
\hline Assateague Island, MD & ASIS.Marsh.6 & MD & 7_Coastal_Delmarva & NPS & Back-barrier Lagoon Marsh \\
\hline Assateague Island, MD & ASIS.Marsh.6 & MD & 7_Coastal_Delmarva & NPS & Back-barrier Lagoon Marsh \\
\hline Assateague Island, MD & ASIS.Marsh.6 & MD & 7_Coastal_Delmarva & NPS & Back-barrier Lagoon Marsh \\
\hline Assateague Island, MD & ASIS.Marsh.11 & MD & 7_Coastal_Delmarva & NPS & Back-barrier Lagoon Marsh \\
\hline Assateague Island, MD & ASIS.Marsh.11 & MD & 7_Coastal_Delmarva & NPS & Back-barrier Lagoon Marsh \\
\hline Assateague Island, MD & ASIS.Marsh.11 & MD & 7_Coastal_Delmarva & NPS & Back-barrier Lagoon Marsh \\
\hline Assateague Island, MD & ASIS.Marsh.11 & MD & 7_Coastal_Delmarva & NPS & Back-barrier Lagoon Marsh \\
\hline $\begin{array}{l}\text { FISHERMAN ISLAND NATIONAL } \\
\text { WILDLIFE REFUGE }\end{array}$ & FIE Plot 1 & VA & 7_Coastal_Delmarva & USFWS & Back-barrier Lagoon Marsh \\
\hline $\begin{array}{l}\text { FISHERMAN ISLAND NATIONAL } \\
\text { WILDLIFE REFUGE }\end{array}$ & FIE Plot 2 & VA & 7_Coastal_Delmarva & USFWS & Back-barrier Lagoon Marsh \\
\hline $\begin{array}{l}\text { FISHERMAN ISLAND NATIONAL } \\
\text { WILDLIFE REFUGE }\end{array}$ & FIE Plot 3 & VA & 7_Coastal_Delmarva & USFWS & Back-barrier Lagoon Marsh \\
\hline $\begin{array}{l}\text { FISHERMAN ISLAND NATIONAL } \\
\text { WILDLIFE REFUGE }\end{array}$ & FIW Plot 1 & VA & 7_Coastal_Delmarva & USFWS & Back-barrier Lagoon Marsh \\
\hline $\begin{array}{l}\text { FISHERMAN ISLAND NATIONAL } \\
\text { WILDLIFE REFUGE }\end{array}$ & FIW Plot 2 & VA & 7_Coastal_Delmarva & USFWS & Back-barrier Lagoon Marsh \\
\hline $\begin{array}{l}\text { FISHERMAN ISLAND NATIONAL } \\
\text { WILDLIFE REFUGE }\end{array}$ & FIW Plot 3 & VA & 7_Coastal_Delmarva & USFWS & Back-barrier Lagoon Marsh \\
\hline $\begin{array}{l}\text { EASTERN SHORE OF VIRGINIA } \\
\text { NATIONAL WILDLIFE REFUGE }\end{array}$ & ESV Plot 3 & VA & 7_Coastal_Delmarva & USFWS & Back-barrier Lagoon Marsh \\
\hline $\begin{array}{l}\text { EASTERN SHORE OF VIRGINIA } \\
\text { NATIONAL WILDLIFE REFUGE }\end{array}$ & ESV Plot 1 & VA & 7_Coastal_Delmarva & USFWS & Back-barrier Lagoon Marsh \\
\hline
\end{tabular}


Table 2.1. Surface elevation table-marker horizon (SET-MH) data.-Continued

\begin{tabular}{|c|c|c|c|c|c|}
\hline SET_Geographical_Location & Site & State & Sub_Region & Partner & Broad_Geomophic_Setting \\
\hline $\begin{array}{l}\text { EASTERN SHORE OF VIRGINIA } \\
\text { NATIONAL WILDLIFE REFUGE }\end{array}$ & ESV Plot 2 & VA & 7_Coastal_Delmarva & USFWS & Back-barrier Lagoon Marsh \\
\hline $\begin{array}{l}\text { EASTERN SHORE OF VIRGINIA } \\
\text { NATIONAL WILDLIFE REFUGE }\end{array}$ & Bull Plot 3 & VA & 7_Coastal_Delmarva & USFWS & Back-barrier Lagoon Marsh \\
\hline $\begin{array}{l}\text { EASTERN SHORE OF VIRGINIA } \\
\text { NATIONAL WILDLIFE REFUGE }\end{array}$ & Bull Plot 2 & VA & 7_Coastal_Delmarva & USFWS & Back-barrier Lagoon Marsh \\
\hline $\begin{array}{l}\text { EASTERN SHORE OF VIRGINIA } \\
\text { NATIONAL WILDLIFE REFUGE }\end{array}$ & Bull Plot 1 & VA & 7_Coastal_Delmarva & USFWS & Back-barrier Lagoon Marsh \\
\hline $\begin{array}{l}\text { CHINCOTEAGUE NATIONAL WILDLIFE } \\
\text { REFUGE }\end{array}$ & Cedar 03 & VA & 7_Coastal_Delmarva & USFWS & Back-barrier Lagoon Marsh \\
\hline $\begin{array}{l}\text { CHINCOTEAGUE NATIONAL WILDLIFE } \\
\text { REFUGE }\end{array}$ & Cedar 02 & VA & 7_Coastal_Delmarva & USFWS & Back-barrier Lagoon Marsh \\
\hline $\begin{array}{l}\text { CHINCOTEAGUE NATIONAL WILDLIFE } \\
\text { REFUGE }\end{array}$ & Cedar 01 & VA & 7_Coastal_Delmarva & USFWS & Back-barrier Lagoon Marsh \\
\hline $\begin{array}{l}\text { CHINCOTEAGUE NATIONAL WILDLIFE } \\
\text { REFUGE }\end{array}$ & BDM3 & VA & 7_Coastal_Delmarva & USFWS & Back-barrier Lagoon Marsh \\
\hline $\begin{array}{l}\text { CHINCOTEAGUE NATIONAL WILDLIFE } \\
\text { REFUGE }\end{array}$ & BDM2 & VA & 7_Coastal_Delmarva & USFWS & Back-barrier Lagoon Marsh \\
\hline $\begin{array}{l}\text { CHINCOTEAGUE NATIONAL WILDLIFE } \\
\text { REFUGE }\end{array}$ & BDM1 & VA & 7_Coastal_Delmarva & USFWS & Back-barrier Lagoon Marsh \\
\hline $\begin{array}{l}\text { CHINCOTEAGUE NATIONAL WILDLIFE } \\
\text { REFUGE }\end{array}$ & APool01 & VA & 7_Coastal_Delmarva & USFWS & Back-barrier Lagoon Marsh \\
\hline $\begin{array}{l}\text { CHINCOTEAGUE NATIONAL WILDLIFE } \\
\text { REFUGE }\end{array}$ & APool02 & VA & 7_Coastal_Delmarva & USFWS & Back-barrier Lagoon Marsh \\
\hline $\begin{array}{l}\text { CHINCOTEAGUE NATIONAL WILDLIFE } \\
\text { REFUGE }\end{array}$ & APool03 & VA & 7_Coastal_Delmarva & USFWS & Back-barrier Lagoon Marsh \\
\hline $\begin{array}{l}\text { WALLOPS ISLAND NATIONAL } \\
\text { WILDLIFE REFUGE }\end{array}$ & Wall 01 & VA & 7_Coastal_Delmarva & USFWS & Back-barrier Lagoon Marsh \\
\hline $\begin{array}{l}\text { WALLOPS ISLAND NATIONAL } \\
\text { WILDLIFE REFUGE }\end{array}$ & Wall 02 & VA & 7_Coastal_Delmarva & USFWS & Back-barrier Lagoon Marsh \\
\hline $\begin{array}{l}\text { WALLOPS ISLAND NATIONAL } \\
\text { WILDLIFE REFUGE }\end{array}$ & Wall 03 & VA & 7_Coastal_Delmarva & USFWS & Back-barrier Lagoon Marsh \\
\hline $\begin{array}{l}\text { CHINCOTEAGUE NATIONAL WILDLIFE } \\
\text { REFUGE }\end{array}$ & SPSM01 & VA & 7_Coastal_Delmarva & USFWS & Back-barrier Lagoon Marsh \\
\hline $\begin{array}{l}\text { CHINCOTEAGUE NATIONAL WILDLIFE } \\
\text { REFUGE }\end{array}$ & SPImp03 & VA & 7_Coastal_Delmarva & USFWS & Back-barrier Lagoon Marsh \\
\hline
\end{tabular}


Table 2.1. Surface elevation table-marker horizon (SET-MH) data.-Continued

\begin{tabular}{|c|c|c|c|c|c|}
\hline SET_Geographical_Location & Site & State & Sub_Region & Partner & Broad_Geomophic_Setting \\
\hline $\begin{array}{l}\text { CHINCOTEAGUE NATIONAL WILDLIFE } \\
\text { REFUGE }\end{array}$ & SPImp01 & VA & 7_Coastal_Delmarva & USFWS & Back-barrier Lagoon Marsh \\
\hline $\begin{array}{l}\text { CHINCOTEAGUE NATIONAL WILDLIFE } \\
\text { REFUGE }\end{array}$ & SPSM02 & VA & 7_Coastal_Delmarva & USFWS & Back-barrier Lagoon Marsh \\
\hline $\begin{array}{l}\text { CHINCOTEAGUE NATIONAL WILDLIFE } \\
\text { REFUGE }\end{array}$ & SPImp02 & VA & 7_Coastal_Delmarva & USFWS & Back-barrier Lagoon Marsh \\
\hline $\begin{array}{l}\text { CHINCOTEAGUE NATIONAL WILDLIFE } \\
\text { REFUGE }\end{array}$ & SPSM03 & VA & 7_Coastal_Delmarva & USFWS & Back-barrier Lagoon Marsh \\
\hline $\begin{array}{l}\text { CHINCOTEAGUE NATIONAL WILDLIFE } \\
\text { REFUGE }\end{array}$ & Wild 02 & VA & 7_Coastal_Delmarva & USFWS & Back-barrier Lagoon Marsh \\
\hline $\begin{array}{l}\text { CHINCOTEAGUE NATIONAL WILDLIFE } \\
\text { REFUGE }\end{array}$ & Wild 01 & VA & 7_Coastal_Delmarva & USFWS & Back-barrier Lagoon Marsh \\
\hline $\begin{array}{l}\text { CHINCOTEAGUE NATIONAL WILDLIFE } \\
\text { REFUGE }\end{array}$ & Wild 03 & VA & 7_Coastal_Delmarva & USFWS & Back-barrier Lagoon Marsh \\
\hline $\begin{array}{l}\text { CHINCOTEAGUE NATIONAL WILDLIFE } \\
\text { REFUGE }\end{array}$ & RPSM02 & VA & 7_Coastal_Delmarva & USFWS & Back-barrier Lagoon Marsh \\
\hline $\begin{array}{l}\text { CHINCOTEAGUE NATIONAL WILDLIFE } \\
\text { REFUGE }\end{array}$ & RPSM01 & VA & 7_Coastal_Delmarva & USFWS & Back-barrier Lagoon Marsh \\
\hline $\begin{array}{l}\text { CHINCOTEAGUE NATIONAL WILDLIFE } \\
\text { REFUGE }\end{array}$ & RPSM03 & VA & 7_Coastal_Delmarva & USFWS & Back-barrier Lagoon Marsh \\
\hline Watchapreague,VA & Watchapreague,VA_Mockhorn West & VA & 7_Coastal_Delmarva & USGS & Back-barrier Lagoon Marsh \\
\hline Watchapreague, VA & Watchapreague,VA_Mockhorn East & VA & 7_Coastal_Delmarva & USGS & Back-barrier Lagoon Marsh \\
\hline Watchapreague,VA & Watchapreague,VA_Curlew Bay & VA & 7_Coastal_Delmarva & USGS & Back-barrier Lagoon Marsh \\
\hline Watchapreague, VA & Watchapreague,VA_Curlew Bay & VA & 7_Coastal_Delmarva & USGS & Back-barrier Lagoon Marsh \\
\hline Watchapreague,VA & Watchapreague,VA_Curlew Bay & VA & 7_Coastal_Delmarva & USGS & Back-barrier Lagoon Marsh \\
\hline Watchapreague,VA & Watchapreague,VA_Curlew Bay & VA & 7_Coastal_Delmarva & USGS & Back-barrier Lagoon Marsh \\
\hline Watchapreague, VA & Watchapreague,VA_Gates Bay & VA & 7_Coastal_Delmarva & USGS & Back-barrier Lagoon Marsh \\
\hline Watchapreague,VA & Watchapreague,VA_Gates Bay & VA & 7_Coastal_Delmarva & USGS & Back-barrier Lagoon Marsh \\
\hline
\end{tabular}


Table 2.1. Surface elevation table-marker horizon (SET-MH) data.-Continued

\begin{tabular}{|c|c|c|c|c|c|}
\hline SET_Geographical_Location & Site & State & Sub_Region & Partner & Broad_Geomophic_Setting \\
\hline VCR - LTER & tidal.creek & VA & 7_Coastal_Delmarva & VCR-LTER & Back-barrier Lagoon Marsh \\
\hline VCR - LTER & low & VA & 7_Coastal_Delmarva & VCR-LTER & Back-barrier Lagoon Marsh \\
\hline VCR - LTER & mid & VA & 7_Coastal_Delmarva & VCR-LTER & Back-barrier Lagoon Marsh \\
\hline VCR - LTER & low & VA & 7_Coastal_Delmarva & VCR-LTER & Back-barrier Lagoon Marsh \\
\hline VCR - LTER & mid & VA & 7_Coastal_Delmarva & VCR-LTER & Back-barrier Lagoon Marsh \\
\hline VCR - LTER & low & VA & 7_Coastal_Delmarva & VCR-LTER & Back-barrier Lagoon Marsh \\
\hline VCR - LTER & $\operatorname{mid}$ & VA & 7_Coastal_Delmarva & VCR-LTER & Back-barrier Lagoon Marsh \\
\hline VCR - LTER & hig & VA & 7_Coastal_Delmarva & VCR-LTER & Back-barrier Lagoon Marsh \\
\hline VCR - LTER & hig & VA & 7_Coastal_Delmarva & VCR-LTER & Back-barrier Lagoon Marsh \\
\hline VCR - LTER & hig & VA & 7_Coastal_Delmarva & VCR-LTER & Back-barrier Lagoon Marsh \\
\hline VCR - LTER & VCR - LTER_FowlingPoint & VA & 7_Coastal_Delmarva & VCR-LTER & Back-barrier Lagoon Marsh \\
\hline VCR - LTER & VCR - LTER_FowlingPoint & VA & 7_Coastal_Delmarva & VCR-LTER & Back-barrier Lagoon Marsh \\
\hline VCR - LTER & VCR - LTER_FowlingPoint & VA & 7_Coastal_Delmarva & VCR-LTER & Back-barrier Lagoon Marsh \\
\hline VCR - LTER & VCR - LTER_FowlingPoint & VA & 7_Coastal_Delmarva & VCR-LTER & Back-barrier Lagoon Marsh \\
\hline VCR - LTER & VCR - LTER_FowlingPoint & VA & 7_Coastal_Delmarva & VCR-LTER & Back-barrier Lagoon Marsh \\
\hline VCR - LTER & VCR - LTER_FowlingPoint & VA & 7_Coastal_Delmarva & VCR-LTER & Back-barrier Lagoon Marsh \\
\hline VCR - LTER & tidal.creek & VA & 7_Coastal_Delmarva & VCR-LTER & Back-barrier Lagoon Marsh \\
\hline VCR - LTER & tidal.creek & VA & 7_Coastal_Delmarva & VCR-LTER & Back-barrier Lagoon Marsh \\
\hline
\end{tabular}


Table 2.1. Surface elevation table-marker horizon (SET-MH) data.-Continued

\begin{tabular}{|c|c|c|c|c|c|}
\hline SET_Geographical_Location & Site & State & Sub_Region & Partner & Broad_Geomophic_Setting \\
\hline VCR - LTER & tidal.creek & VA & 7_Coastal_Delmarva & VCR-LTER & Back-barrier Lagoon Marsh \\
\hline VCR - LTER & tidal.creek & VA & 7_Coastal_Delmarva & VCR-LTER & Back-barrier Lagoon Marsh \\
\hline VCR - LTER & VCR - LTER_ChimneyPole & VA & 7_Coastal_Delmarva & VCR-LTER & Back-barrier Lagoon Marsh \\
\hline VCR - LTER & VCR - LTER_ChimneyPole & VA & 7_Coastal_Delmarva & VCR-LTER & Back-barrier Lagoon Marsh \\
\hline VCR - LTER & VCR - LTER_ChimneyPole & VA & 7_Coastal_Delmarva & VCR-LTER & Back-barrier Lagoon Marsh \\
\hline VCR - LTER & VCR - LTER_ChimneyPole & VA & 7_Coastal_Delmarva & VCR-LTER & Back-barrier Lagoon Marsh \\
\hline Nanticoke River & Nanticoke River_1 & MD & 8_Eastern_Chesapeake_Bay & Academic Institution & Estuarine Embayment \\
\hline Nanticoke River & Nanticoke River_1 & MD & 8_Eastern_Chesapeake_Bay & Academic Institution & Estuarine Embayment \\
\hline Nanticoke River & Nanticoke River_1 & MD & 8_Eastern_Chesapeake_Bay & Academic Institution & Estuarine Embayment \\
\hline Nanticoke River & Nanticoke River_2 & MD & 8_Eastern_Chesapeake_Bay & Academic Institution & Estuarine Brackish Marsh \\
\hline Nanticoke River & Nanticoke River_2 & MD & 8_Eastern_Chesapeake_Bay & Academic Institution & Estuarine Brackish Marsh \\
\hline Nanticoke River & Nanticoke River_2 & MD & 8_Eastern_Chesapeake_Bay & Academic Institution & Estuarine Brackish Marsh \\
\hline Nanticoke River & Nanticoke River_3 & MD & 8_Eastern_Chesapeake_Bay & Academic Institution & Estuarine Brackish Marsh \\
\hline Nanticoke River & Nanticoke River_3 & MD & 8_Eastern_Chesapeake_Bay & Academic Institution & Estuarine Brackish Marsh \\
\hline Nanticoke River & Nanticoke River_3 & MD & 8_Eastern_Chesapeake_Bay & Academic Institution & Estuarine Brackish Marsh \\
\hline Nanticoke River & Nanticoke River_4 & MD & 8_Eastern_Chesapeake_Bay & Academic Institution & Estuarine Embayment \\
\hline Nanticoke River & Nanticoke River_4 & MD & 8_Eastern_Chesapeake_Bay & Academic Institution & Estuarine Embayment \\
\hline Nanticoke River & Nanticoke River_4 & MD & 8_Eastern_Chesapeake_Bay & Academic Institution & Estuarine Embayment \\
\hline
\end{tabular}


Table 2.1. Surface elevation table-marker horizon (SET-MH) data.-Continued

\begin{tabular}{|c|c|c|c|c|c|}
\hline SET_Geographical_Location & Site & State & Sub_Region & Partner & Broad_Geomophic_Setting \\
\hline Monie Bay, MD & MCMST2L & MD & 8_Eastern_Chesapeake_Bay & NERR & Estuarine Embayment \\
\hline Monie Bay, MD & MCMST2H & MD & 8_Eastern_Chesapeake_Bay & NERR & Estuarine Embayment \\
\hline Monie Bay, MD & MCMST1L & MD & 8_Eastern_Chesapeake_Bay & NERR & Estuarine Embayment \\
\hline Monie Bay, MD & MCMST3L & MD & 8_Eastern_Chesapeake_Bay & NERR & Estuarine Embayment \\
\hline Monie Bay, MD & MCMST3H & MD & 8_Eastern_Chesapeake_Bay & NERR & Estuarine Embayment \\
\hline Monie Bay, MD & MCMST1H & MD & 8_Eastern_Chesapeake_Bay & NERR & Estuarine Embayment \\
\hline Monie Bay, MD & MCHST3L & MD & 8_Eastern_Chesapeake_Bay & NERR & Estuarine Embayment \\
\hline Monie Bay, MD & MCHST1H & MD & 8_Eastern_Chesapeake_Bay & NERR & Estuarine Embayment \\
\hline Monie Bay, MD & MCHST3H & MD & 8_Eastern_Chesapeake_Bay & NERR & Estuarine Embayment \\
\hline Monie Bay, MD & MCHST1L & MD & 8_Eastern_Chesapeake_Bay & NERR & Estuarine Embayment \\
\hline Monie Bay, MD & MCHST2L & MD & 8_Eastern_Chesapeake_Bay & NERR & Estuarine Embayment \\
\hline Monie Bay, MD & MCHST2H & MD & 8_Eastern_Chesapeake_Bay & NERR & Estuarine Embayment \\
\hline Deal Island WMA & Deal Island WMA_Deal2-unditched & MD & 8_Eastern_Chesapeake_Bay & NERR & Estuarine Brackish Marsh \\
\hline Deal Island WMA & Deal Island WMA_Deal2-unditched & MD & 8_Eastern_Chesapeake_Bay & NERR & Estuarine Brackish Marsh \\
\hline Deal Island WMA & Deal Island WMA_Deal2-unditched & MD & 8_Eastern_Chesapeake_Bay & NERR & Estuarine Brackish Marsh \\
\hline Deal Island WMA & Deal Island WMA_Deal1-ditched & MD & 8_Eastern_Chesapeake_Bay & NERR & Estuarine Brackish Marsh \\
\hline Deal Island WMA & Deal Island WMA_Deal1-ditched & MD & 8_Eastern_Chesapeake_Bay & NERR & Estuarine Brackish Marsh \\
\hline Deal Island WMA & Deal Island WMA_Deal1-ditched & MD & 8_Eastern_Chesapeake_Bay & NERR & Estuarine Brackish Marsh \\
\hline
\end{tabular}


Table 2.1. Surface elevation table-marker horizon (SET-MH) data.-Continued

\begin{tabular}{|c|c|c|c|c|c|}
\hline SET_Geographical_Location & Site & State & Sub_Region & Partner & Broad_Geomophic_Setting \\
\hline Deal Island WMA & Deal Island WMA_Deal4-ditched & MD & 8_Eastern_Chesapeake_Bay & NERR & Estuarine Brackish Marsh \\
\hline Deal Island WMA & Deal Island WMA_Deal4-ditched & MD & 8_Eastern_Chesapeake_Bay & NERR & Estuarine Brackish Marsh \\
\hline Deal Island WMA & Deal Island WMA_Deal4-ditched & MD & 8_Eastern_Chesapeake_Bay & NERR & Estuarine Brackish Marsh \\
\hline Deal Island WMA & Deal Island WMA_Deal3-unditched & MD & 8_Eastern_Chesapeake_Bay & NERR & Estuarine Brackish Marsh \\
\hline Deal Island WMA & Deal Island WMA_Deal3-unditched & MD & 8_Eastern_Chesapeake_Bay & NERR & Estuarine Brackish Marsh \\
\hline Deal Island WMA & Deal Island WMA_Deal3-unditched & MD & 8_Eastern_Chesapeake_Bay & NERR & Estuarine Brackish Marsh \\
\hline Monie Bay, MD & Monie Bay, MD_Monie Creek-unditched & MD & 8_Eastern_Chesapeake_Bay & NERR & Estuarine Brackish Marsh \\
\hline Monie Bay, MD & Monie Bay, MD_Monie Creek-unditched & MD & 8_Eastern_Chesapeake_Bay & NERR & Estuarine Brackish Marsh \\
\hline Monie Bay, MD & Monie Bay, MD_Monie Creek-unditched & MD & 8_Eastern_Chesapeake_Bay & NERR & Estuarine Brackish Marsh \\
\hline Saxis WMA & Saxis & VA & 8_Eastern_Chesapeake_Bay & USGS & Estuarine Embayment \\
\hline Saxis WMA & Saxis & VA & 8_Eastern_Chesapeake_Bay & USGS & Estuarine Embayment \\
\hline Saxis WMA & Saxis & VA & 8_Eastern_Chesapeake_Bay & USGS & Estuarine Embayment \\
\hline Saxis WMA & Saxis & VA & 8_Eastern_Chesapeake_Bay & USGS & Estuarine Embayment \\
\hline Audubon Property- Farm Creek Wetlands & Audubon.Property.Fishing.Bay & MD & 8_Eastern_Chesapeake_Bay & USGS & Estuarine Embayment \\
\hline Audubon Property- Farm Creek Wetlands & Audubon.Property.Fishing.Bay & MD & 8_Eastern_Chesapeake_Bay & USGS & Estuarine Embayment \\
\hline Fishing Bay WMA & Fishing.Bay.8A & MD & 8_Eastern_Chesapeake_Bay & USGS & Estuarine Embayment \\
\hline Fishing Bay WMA & Fishing.Bay.8A & MD & 8_Eastern_Chesapeake_Bay & USGS & Estuarine Embayment \\
\hline Fishing Bay WMA & Fishing.Bay.8A & MD & 8_Eastern_Chesapeake_Bay & USGS & Estuarine Embayment \\
\hline
\end{tabular}


Table 2.1. Surface elevation table-marker horizon (SET-MH) data.-Continued

\begin{tabular}{|c|c|c|c|c|c|}
\hline SET_Geographical_Location & Site & State & Sub_Region & Partner & Broad_Geomophic_Setting \\
\hline Fishing Bay WMA & Fishing.Bay.8A & MD & 8_Eastern_Chesapeake_Bay & USGS & Estuarine Embayment \\
\hline Fishing Bay WMA & Fishing.Bay.8D & MD & 8_Eastern_Chesapeake_Bay & USGS & Estuarine Embayment \\
\hline Fishing Bay WMA & Fishing.Bay.8D & MD & 8_Eastern_Chesapeake_Bay & USGS & Estuarine Embayment \\
\hline Fishing Bay WMA & Fishing.Bay.8D & MD & 8_Eastern_Chesapeake_Bay & USGS & Estuarine Embayment \\
\hline Fishing Bay WMA & Fishing.Bay.8D & MD & 8_Eastern_Chesapeake_Bay & USGS & Estuarine Embayment \\
\hline Blackwater NWR & BWB_Unit3A & MD & 8_Eastern_Chesapeake_Bay & USGS & Estuarine Brackish Marsh \\
\hline Blackwater NWR & BWB_Unit3A & MD & 8_Eastern_Chesapeake_Bay & USGS & Estuarine Brackish Marsh \\
\hline Blackwater NWR & BWB_Unit3A & MD & 8_Eastern_Chesapeake_Bay & USGS & Estuarine Brackish Marsh \\
\hline Blackwater NWR & BWB_Unit3D & MD & 8_Eastern_Chesapeake_Bay & USGS & Estuarine Brackish Marsh \\
\hline Blackwater NWR & BWB_Unit3D & MD & 8_Eastern_Chesapeake_Bay & USGS & Estuarine Brackish Marsh \\
\hline Blackwater NWR & BWB_Unit3B & MD & 8_Eastern_Chesapeake_Bay & USGS & Estuarine Brackish Marsh \\
\hline Blackwater NWR & BWB_Unit3B & MD & 8_Eastern_Chesapeake_Bay & USGS & Estuarine Brackish Marsh \\
\hline Blackwater NWR & BWB_Unit3B & MD & 8_Eastern_Chesapeake_Bay & USGS & Estuarine Brackish Marsh \\
\hline Blackwater NWR & BWB_Unit3C & MD & 8_Eastern_Chesapeake_Bay & USGS & Estuarine Brackish Marsh \\
\hline Blackwater NWR & BWB_Unit3C & MD & 8_Eastern_Chesapeake_Bay & USGS & Estuarine Brackish Marsh \\
\hline Blackwater NWR & BWB_Unit3C & MD & 8_Eastern_Chesapeake_Bay & USGS & Estuarine Brackish Marsh \\
\hline Blackwater NWR & Blackwater.7A & MD & 8_Eastern_Chesapeake_Bay & USGS & Estuarine Brackish Marsh \\
\hline Blackwater NWR & Blackwater.7A & MD & 8 Eastern Chesapeake Bay & USGS & Estuarine Brackish Marsh \\
\hline
\end{tabular}


Table 2.1. Surface elevation table-marker horizon (SET-MH) data.-Continued

\begin{tabular}{|c|c|c|c|c|c|}
\hline SET_Geographical_Location & Site & State & Sub_Region & Partner & Broad_Geomophic_Setting \\
\hline Blackwater NWR & Blackwater.7A & MD & 8_Eastern_Chesapeake_Bay & USGS & Estuarine Brackish Marsh \\
\hline Blackwater NWR & Blackwater.7A & MD & 8_Eastern_Chesapeake_Bay & USGS & Estuarine Brackish Marsh \\
\hline Blackwater NWR & Blackwater.A31 & MD & 8_Eastern_Chesapeake_Bay & USGS & Estuarine Brackish Marsh \\
\hline Blackwater NWR & Blackwater.A31 & $\mathrm{MD}$ & 8_Eastern_Chesapeake_Bay & USGS & Estuarine Brackish Marsh \\
\hline Blackwater NWR & Blackwater.A31 & MD & 8_Eastern_Chesapeake_Bay & USGS & Estuarine Brackish Marsh \\
\hline Blackwater NWR & Blackwater.A31 & MD & 8_Eastern_Chesapeake_Bay & USGS & Estuarine Brackish Marsh \\
\hline Blackwater NWR & Blackwater.A31 & MD & 8_Eastern_Chesapeake_Bay & USGS & Estuarine Brackish Marsh \\
\hline Blackwater NWR & Blackwater.7D & MD & 8_Eastern_Chesapeake_Bay & USGS & Estuarine Brackish Marsh \\
\hline Blackwater NWR & BWB_Unit2B & MD & 8_Eastern_Chesapeake_Bay & USGS & Estuarine Brackish Marsh \\
\hline Blackwater NWR & BWB_Unit2B & MD & 8_Eastern_Chesapeake_Bay & USGS & Estuarine Brackish Marsh \\
\hline Blackwater NWR & BWB_Unit2B & MD & 8_Eastern_Chesapeake_Bay & USGS & Estuarine Brackish Marsh \\
\hline Blackwater NWR & Blackwater.7D & MD & 8_Eastern_Chesapeake_Bay & USGS & Estuarine Brackish Marsh \\
\hline Blackwater NWR & Blackwater.7D & MD & 8_Eastern_Chesapeake_Bay & USGS & Estuarine Brackish Marsh \\
\hline Blackwater NWR & Blackwater.7D & MD & 8_Eastern_Chesapeake_Bay & USGS & Estuarine Brackish Marsh \\
\hline Blackwater NWR & BWB_Unit2D & MD & 8_Eastern_Chesapeake_Bay & USGS & Estuarine Brackish Marsh \\
\hline Blackwater NWR & BWB_Unit2D & MD & 8_Eastern_Chesapeake_Bay & USGS & Estuarine Brackish Marsh \\
\hline Blackwater NWR & BWB_Unit2D & MD & 8_Eastern_Chesapeake_Bay & USGS & Estuarine Brackish Marsh \\
\hline Blackwater NWR & BWB_Unit2A & MD & 8_Eastern_Chesapeake_Bay & USGS & Estuarine Brackish Marsh \\
\hline
\end{tabular}


Table 2.1. Surface elevation table-marker horizon (SET-MH) data.-Continued

\begin{tabular}{|c|c|c|c|c|c|}
\hline SET_Geographical_Location & Site & State & Sub_Region & Partner & Broad_Geomophic_Setting \\
\hline Blackwater NWR & BWB_Unit2A & MD & 8_Eastern_Chesapeake_Bay & USGS & Estuarine Brackish Marsh \\
\hline Blackwater NWR & BWB_Unit2A & MD & 8_Eastern_Chesapeake_Bay & USGS & Estuarine Brackish Marsh \\
\hline Blackwater NWR & BWB_Unit2C & MD & 8_Eastern_Chesapeake_Bay & USGS & Estuarine Brackish Marsh \\
\hline Blackwater NWR & BWB_Unit2C & MD & 8_Eastern_Chesapeake_Bay & USGS & Estuarine Brackish Marsh \\
\hline Blackwater NWR & BWB_Unit2C & MD & 8_Eastern_Chesapeake_Bay & USGS & Estuarine Brackish Marsh \\
\hline Blackwater NWR & Blackwater.A10 & MD & 8_Eastern_Chesapeake_Bay & USGS & Estuarine Brackish Marsh \\
\hline Blackwater NWR & Blackwater.A10 & MD & 8_Eastern_Chesapeake_Bay & USGS & Estuarine Brackish Marsh \\
\hline Blackwater NWR & Blackwater.A10 & MD & 8_Eastern_Chesapeake_Bay & USGS & Estuarine Brackish Marsh \\
\hline Blackwater NWR & Blackwater.A10 & MD & 8_Eastern_Chesapeake_Bay & USGS & Estuarine Brackish Marsh \\
\hline Blackwater NWR & BWB_Unit1D & MD & 8_Eastern_Chesapeake_Bay & USGS & Estuarine Brackish Marsh \\
\hline Blackwater NWR & BWB_Unit1D & MD & 8_Eastern_Chesapeake_Bay & USGS & Estuarine Brackish Marsh \\
\hline Blackwater NWR & BWB_Unit1D & MD & 8_Eastern_Chesapeake_Bay & USGS & Estuarine Brackish Marsh \\
\hline Blackwater NWR & BWB_Unit1C & MD & 8_Eastern_Chesapeake_Bay & USGS & Estuarine Brackish Marsh \\
\hline Blackwater NWR & BWB_Unit1C & MD & 8_Eastern_Chesapeake_Bay & USGS & Estuarine Brackish Marsh \\
\hline Blackwater NWR & BWB_Unit1C & MD & 8_Eastern_Chesapeake_Bay & USGS & Estuarine Brackish Marsh \\
\hline Blackwater NWR & Blackwater.A33 & MD & 8_Eastern_Chesapeake_Bay & USGS & Estuarine Brackish Marsh \\
\hline Blackwater NWR & BWB_Unit1B & MD & 8_Eastern_Chesapeake_Bay & USGS & Estuarine Brackish Marsh \\
\hline Blackwater NWR & BWB Unit1B & MD & 8 Eastern Chesapeake Bay & USGS & Estuarine Brackish Marsh \\
\hline
\end{tabular}


Table 2.1. Surface elevation table-marker horizon (SET-MH) data.-Continued

\begin{tabular}{|c|c|c|c|c|c|}
\hline SET_Geographical_Location & Site & State & Sub_Region & Partner & Broad_Geomophic_Setting \\
\hline Blackwater NWR & Blackwater.A33 & MD & 8_Eastern_Chesapeake_Bay & USGS & Estuarine Brackish Marsh \\
\hline Blackwater NWR & BWB_Unit1B & MD & 8_Eastern_Chesapeake_Bay & USGS & Estuarine Brackish Marsh \\
\hline Blackwater NWR & BWB_Unit1A & MD & 8_Eastern_Chesapeake_Bay & USGS & Estuarine Brackish Marsh \\
\hline Blackwater NWR & BWB_Unit1A & MD & 8_Eastern_Chesapeake_Bay & USGS & Estuarine Brackish Marsh \\
\hline Blackwater NWR & BWB_Unit1A & MD & 8_Eastern_Chesapeake_Bay & USGS & Estuarine Brackish Marsh \\
\hline Blackwater NWR & Blackwater.A33 & MD & 8_Eastern_Chesapeake_Bay & USGS & Estuarine Brackish Marsh \\
\hline Blackwater NWR & Blackwater.A33 & MD & 8_Eastern_Chesapeake_Bay & USGS & Estuarine Brackish Marsh \\
\hline Blackwater NWR & Blackwater.A33 & MD & 8_Eastern_Chesapeake_Bay & USGS & Estuarine Brackish Marsh \\
\hline Eastern Neck, NWR & Eastern.Neck & MD & 8_Eastern_Chesapeake_Bay & USGS & Estuarine Embayment \\
\hline Eastern Neck, NWR & Eastern.Neck & MD & 8_Eastern_Chesapeake_Bay & USGS & Estuarine Embayment \\
\hline Eastern Neck, NWR & Eastern.Neck & $\mathrm{MD}$ & 8_Eastern_Chesapeake_Bay & USGS & Estuarine Embayment \\
\hline Eastern Neck, NWR & Eastern.Neck & MD & 8_Eastern_Chesapeake_Bay & USGS & Estuarine Embayment \\
\hline Blackwater NWR & BWB_Unit3D & MD & 8_Eastern_Chesapeake_Bay & USGS & Estuarine Brackish Marsh \\
\hline Blackwater NWR & Blackwater.A33 & MD & 8_Eastern_Chesapeake_Bay & USGS & Estuarine Brackish Marsh \\
\hline Blackwater NWR & Blackwater.A33 & MD & 8_Eastern_Chesapeake_Bay & USGS & Estuarine Brackish Marsh \\
\hline Goodwin Island & $\begin{array}{l}\text { Goodwin Island_Middle Island - Water } \\
\text { Quality Station }\end{array}$ & VA & 9_Western_Chesapeake_Bay & NERR & Estuarine Embayment \\
\hline Goodwin Island & Main Island - Reference Site Transect & VA & 9_Western_Chesapeake_Bay & NERR & Estuarine Embayment \\
\hline Goodwin Island & Main Island - Reference Site Transect & VA & 9_Western_Chesapeake_Bay & NERR & Estuarine Embayment \\
\hline
\end{tabular}


Table 2.1. Surface elevation table-marker horizon (SET-MH) data.-Continued

\begin{tabular}{|c|c|c|c|c|c|}
\hline SET_Geographical_Location & Site & State & Sub_Region & Partner & Broad_Geomophic_Setting \\
\hline Goodwin Island & $\begin{array}{l}\text { Goodwin Island_Main Island - Thorofare } \\
\text { Transect }\end{array}$ & VA & 9_Western_Chesapeake_Bay & NERR & Estuarine Embayment \\
\hline Goodwin Island & $\begin{array}{l}\text { Goodwin Island_Main Island - Thorofare } \\
\text { Transect }\end{array}$ & VA & 9_Western_Chesapeake_Bay & NERR & Estuarine Embayment \\
\hline Goodwin Island & Goodwin Island_Middle Island Transect & VA & 9_Western_Chesapeake_Bay & NERR & Estuarine Embayment \\
\hline Goodwin Island & Goodwin Island_Middle Island Transect & VA & 9_Western_Chesapeake_Bay & NERR & Estuarine Embayment \\
\hline Goodwin Island & Goodwin Island_Middle Island Transect & VA & 9_Western_Chesapeake_Bay & NERR & Estuarine Embayment \\
\hline Goodwin Island & $\begin{array}{l}\text { Goodwin Island_Main Island - North } \\
\text { Transect }\end{array}$ & VA & 9_Western_Chesapeake_Bay & NERR & Estuarine Embayment \\
\hline Goodwin Island & $\begin{array}{l}\text { Goodwin Island_Main Island - North } \\
\text { Transect }\end{array}$ & VA & 9_Western_Chesapeake_Bay & NERR & Estuarine Embayment \\
\hline Catlett Island & Catlett Island_Inner Site & VA & 9_Western_Chesapeake_Bay & NERR & Estuarine Embayment \\
\hline Catlett Island & Catlett Island_Inner Site & VA & 9_Western_Chesapeake_Bay & NERR & Estuarine Embayment \\
\hline Taskinas Creek & Taskinas Creek_Reference Site Transect & VA & 9_Western_Chesapeake_Bay & NERR & Estuarine Brackish Marsh \\
\hline Catlett Island & Catlett Island_Outer Site & VA & 9_Western_Chesapeake_Bay & NERR & Estuarine Embayment \\
\hline Catlett Island & Catlett Island_Outer Site & VA & 9_Western_Chesapeake_Bay & NERR & Estuarine Embayment \\
\hline Taskinas Creek & Taskinas Creek_Reference Site Transect & VA & 9_Western_Chesapeake_Bay & NERR & Estuarine Brackish Marsh \\
\hline Smithsonian Environmental Research Center & SERC & MD & 9_Western_Chesapeake_Bay & SERC & Estuarine Embayment \\
\hline Smithsonian Environmental Research Center & SERC & MD & 9_Western_Chesapeake_Bay & SERC & Estuarine Embayment \\
\hline Smithsonian Environmental Research Center & SERC & MD & 9_Western_Chesapeake_Bay & SERC & Estuarine Embayment \\
\hline Smithsonian Environmental Research Center & SERC & MD & 9_Western_Chesapeake_Bay & SERC & Estuarine Embayment \\
\hline Smithsonian Environmental Research Center & SERC & MD & 9_Western_Chesapeake_Bay & SERC & Estuarine Embayment \\
\hline
\end{tabular}


Table 2.1. Surface elevation table-marker horizon (SET-MH) data.-Continued

\begin{tabular}{|c|c|c|c|c|c|}
\hline SET_Geographical_Location & Site & State & Sub_Region & Partner & Broad_Geomophic_Setting \\
\hline Smithsonian Environmental Research Center & SERC & MD & 9_Western_Chesapeake_Bay & SERC & Estuarine Embayment \\
\hline Smithsonian Environmental Research Center & SERC & MD & 9_Western_Chesapeake_Bay & SERC & Estuarine Embayment \\
\hline Smithsonian Environmental Research Center & SERC & MD & 9_Western_Chesapeake_Bay & SERC & Estuarine Embayment \\
\hline Smithsonian Environmental Research Center & SERC & MD & 9_Western_Chesapeake_Bay & SERC & Estuarine Embayment \\
\hline Smithsonian Environmental Research Center & SERC & MD & 9_Western_Chesapeake_Bay & SERC & Estuarine Embayment \\
\hline Smithsonian Environmental Research Center & SERC & MD & 9_Western_Chesapeake_Bay & SERC & Estuarine Embayment \\
\hline Smithsonian Environmental Research Center & SERC & MD & 9_Western_Chesapeake_Bay & SERC & Estuarine Embayment \\
\hline Smithsonian Environmental Research Center & SERC & MD & 9_Western_Chesapeake_Bay & SERC & Estuarine Embayment \\
\hline Smithsonian Environmental Research Center & SERC & MD & 9_Western_Chesapeake_Bay & SERC & Estuarine Embayment \\
\hline Smithsonian Environmental Research Center & SERC & MD & 9_Western_Chesapeake_Bay & SERC & Estuarine Embayment \\
\hline Smithsonian Environmental Research Center & SERC & MD & 9_Western_Chesapeake_Bay & SERC & Estuarine Embayment \\
\hline Smithsonian Environmental Research Center & SERC & MD & 9_Western_Chesapeake_Bay & SERC & Estuarine Embayment \\
\hline Smithsonian Environmental Research Center & SERC & MD & 9_Western_Chesapeake_Bay & SERC & Estuarine Embayment \\
\hline Smithsonian Environmental Research Center & SERC & MD & 9_Western_Chesapeake_Bay & SERC & Estuarine Embayment \\
\hline Smithsonian Environmental Research Center & SERC & MD & 9_Western_Chesapeake_Bay & SERC & Estuarine Embayment \\
\hline Smithsonian Environmental Research Center & SERC & MD & 9_Western_Chesapeake_Bay & SERC & Estuarine Embayment \\
\hline Smithsonian Environmental Research Center & SERC & MD & 9_Western_Chesapeake_Bay & SERC & Estuarine Embayment \\
\hline Smithsonian Environmental Research Center & SERC & MD & 9_Western_Chesapeake_Bay & SERC & Estuarine Embayment \\
\hline
\end{tabular}


Table 2.1. Surface elevation table-marker horizon (SET-MH) data.-Continued

\begin{tabular}{|c|c|c|c|c|c|}
\hline SET_Geographical_Location & Site & State & Sub_Region & Partner & Broad_Geomophic_Setting \\
\hline Smithsonian Environmental Research Center & SERC & MD & 9_Western_Chesapeake_Bay & SERC & Estuarine Embayment \\
\hline Smithsonian Environmental Research Center & SERC & MD & 9_Western_Chesapeake_Bay & SERC & Estuarine Embayment \\
\hline Smithsonian Environmental Research Center & SERC & MD & 9_Western_Chesapeake_Bay & SERC & Estuarine Embayment \\
\hline Smithsonian Environmental Research Center & SERC & MD & 9_Western_Chesapeake_Bay & SERC & Estuarine Embayment \\
\hline Smithsonian Environmental Research Center & SERC & MD & 9_Western_Chesapeake_Bay & SERC & Estuarine Embayment \\
\hline Smithsonian Environmental Research Center & SERC & MD & 9_Western_Chesapeake_Bay & SERC & Estuarine Embayment \\
\hline Smithsonian Environmental Research Center & SERC & MD & 9_Western_Chesapeake_Bay & SERC & Estuarine Embayment \\
\hline Smithsonian Environmental Research Center & SERC & MD & 9_Western_Chesapeake_Bay & SERC & Estuarine Embayment \\
\hline Smithsonian Environmental Research Center & SERC & MD & 9_Western_Chesapeake_Bay & SERC & Estuarine Embayment \\
\hline Smithsonian Environmental Research Center & SERC & MD & 9_Western_Chesapeake_Bay & SERC & Estuarine Embayment \\
\hline Smithsonian Environmental Research Center & SERC & MD & 9_Western_Chesapeake_Bay & SERC & Estuarine Embayment \\
\hline Smithsonian Environmental Research Center & SERC & MD & 9_Western_Chesapeake_Bay & SERC & Estuarine Embayment \\
\hline Smithsonian Environmental Research Center & SERC & MD & 9_Western_Chesapeake_Bay & SERC & Estuarine Embayment \\
\hline Smithsonian Environmental Research Center & SERC & MD & 9_Western_Chesapeake_Bay & SERC & Estuarine Embayment \\
\hline Smithsonian Environmental Research Center & SERC & MD & 9_Western_Chesapeake_Bay & SERC & Estuarine Embayment \\
\hline Smithsonian Environmental Research Center & SERC & MD & 9_Western_Chesapeake_Bay & SERC & Estuarine Embayment \\
\hline Smithsonian Environmental Research Center & SERC & MD & 9_Western_Chesapeake_Bay & SERC & Estuarine Embayment \\
\hline Smithsonian Environmental Research Center & SERC & MD & 9_Western_Chesapeake_Bay & SERC & Estuarine Embayment \\
\hline
\end{tabular}


Table 2.1. Surface elevation table-marker horizon (SET-MH) data.-Continued

\begin{tabular}{|c|c|c|c|c|c|}
\hline SET_Geographical_Location & Site & State & Sub_Region & Partner & Broad_Geomophic_Setting \\
\hline Smithsonian Environmental Research Center & SERC & MD & 9_Western_Chesapeake_Bay & SERC & Estuarine Embayment \\
\hline Western Shore, Cove Point & Western Shore, Cove Point_Cove Point & MD & 9_Western_Chesapeake_Bay & Academic Institution & Estuarine Embayment \\
\hline Western Shore, Cove Point & Western Shore, Cove Point_Cove Point & MD & 9_Western_Chesapeake_Bay & Academic Institution & Estuarine Embayment \\
\hline Western Shore, Parkers Creek & $\begin{array}{l}\text { Western Shore, Parkers Creek_Parkers } \\
\text { Creek }\end{array}$ & MD & 9_Western_Chesapeake_Bay & Academic Institution & Estuarine Embayment \\
\hline Western Shore, Parkers Creek & $\begin{array}{l}\text { Western Shore, Parkers Creek_Parkers } \\
\text { Creek }\end{array}$ & MD & 9_Western_Chesapeake_Bay & Academic Institution & Estuarine Embayment \\
\hline Western Shore, Parkers Creek & $\begin{array}{l}\text { Western Shore, Parkers Creek_Parkers } \\
\text { Creek }\end{array}$ & MD & 9_Western_Chesapeake_Bay & Academic Institution & Estuarine Embayment \\
\hline Western Shore, Parkers Creek & $\begin{array}{l}\text { Western Shore, Parkers Creek_Parkers } \\
\text { Creek }\end{array}$ & MD & 9_Western_Chesapeake_Bay & Academic Institution & Estuarine Embayment \\
\hline SERC, MD & Hog.Island.SERC & MD & 9_Western_Chesapeake_Bay & USGS & Estuarine Embayment \\
\hline SERC, MD & Hog.Island.SERC & MD & 9_Western_Chesapeake_Bay & USGS & Estuarine Embayment \\
\hline SERC, MD & Hog.Island.SERC & MD & 9_Western_Chesapeake_Bay & USGS & Estuarine Embayment \\
\hline SERC, MD & Hog.Island.SERC & MD & 9_Western_Chesapeake_Bay & USGS & Estuarine Embayment \\
\hline
\end{tabular}




\section{Appendix 3. Best Model Summaries}

Model summaries for the deviation from expected surface elevation model and storm surge submodel using the eligible surface elevation table (SET) data (table 3.1 and table 3.2, respectively).

Table 3.1. Summary output for best deviation from expected surface elevation change model (model 15e). Adjusted values for reduced effective sample size (170) in parentheses when differs from unadjusted values ( $n=223)$.

$[<$, less than $]$

\begin{tabular}{|c|c|c|c|c|}
\hline \multicolumn{5}{|c|}{ Residuals } \\
\hline Minimum & 1st quarter & Median & 3rd quarter & Maximum \\
\hline-47.03 & -4.28 & -1.65 & 4.06 & 55.90 \\
\hline Intercept & -23.90 & $4.18(4.77)$ & $-5.73(-5.00)$ & $<0.0001$ \\
\hline Distance & 186.16 & $33.41(38.26)$ & $5.57(4.87)$ & $<0.0001$ \\
\hline Position & 22.39 & $6.17(7.07)$ & $3.63(3.17)$ & $<0.001(<0.005)$ \\
\hline Distance $\times$ Position & -103.66 & $31.91(36.55)$ & $-3.25(-2.84)$ & $<0.005(<0.01)$ \\
\hline
\end{tabular}

Residual standard error: 12.04 on 118 degrees of freedom

Multiple R-squared: 0.16

Adjusted R-squared: 0.14

F-statistic: 10.33 on 54 and $218 \mathrm{DF}$, p-value: $<0.0001$

Table 3.2. Summary output for the best storm surge submodel (model 3) using eligible surface elevation table (SET) dataset. Adjusted values for reduced effective sample size (156) in parentheses when differs from unadjusted values ( $n=223$ ).

$[<$, less than $]$

\begin{tabular}{|c|c|c|c|c|}
\hline \multicolumn{5}{|c|}{ Residuals } \\
\hline Minimum & 1st quarter & Median & 3rd quarter & Maximum \\
\hline-2.18 & 0.00 & 0.01 & 0.33 & 2.68 \\
\hline Intercept & 24.41 & $4.56(5.45)$ & $5.36(4.48)$ & $<0.0001$ \\
\hline Distance & -54.53 & $9.83(11.75)$ & $-5.55(-4.64)$ & $<0.0001$ \\
\hline
\end{tabular}

Null deviance: 232.288 on 222 degrees of freedom

Residual deviance: 89.249 on 220 degrees of freedom

Akaike's Information Criteria: 95.249 

For additional information, contact:

Director, Patuxent Wildlife Research Center

U.S. Geological Survey

12311 Beech Forest Road

Laurel, MD 20708

or visit our website at:

https://www.usgs.gov/centers/pwrc

Publishing support provided by the West Trenton Publishing Service Center 

a.1. 1.5. A. 1.5 a

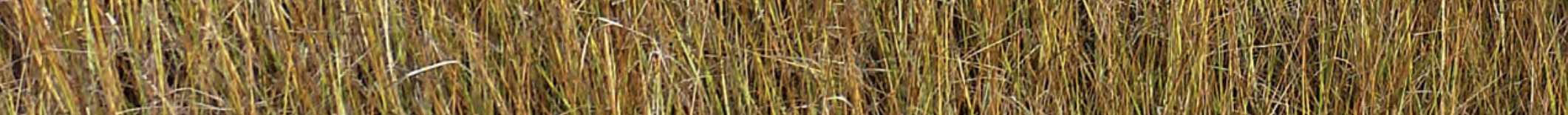

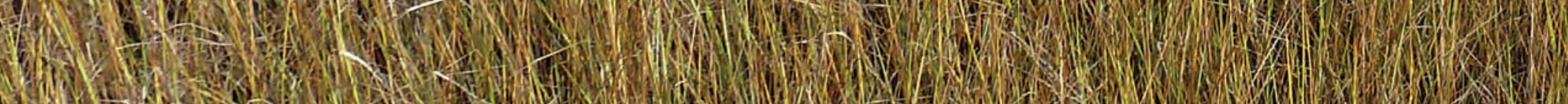

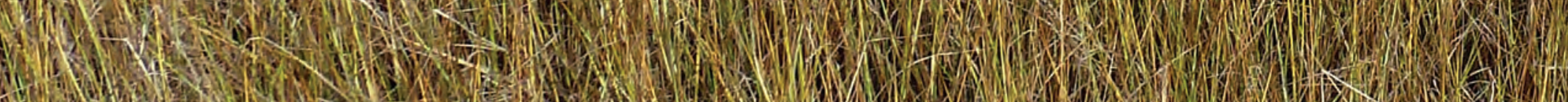
4 . No

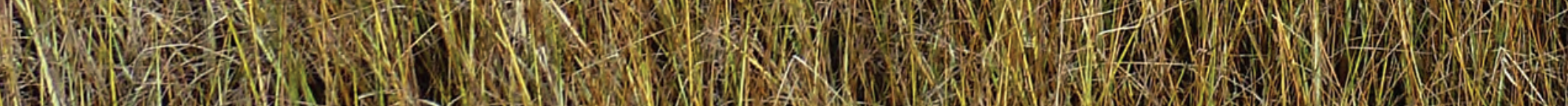

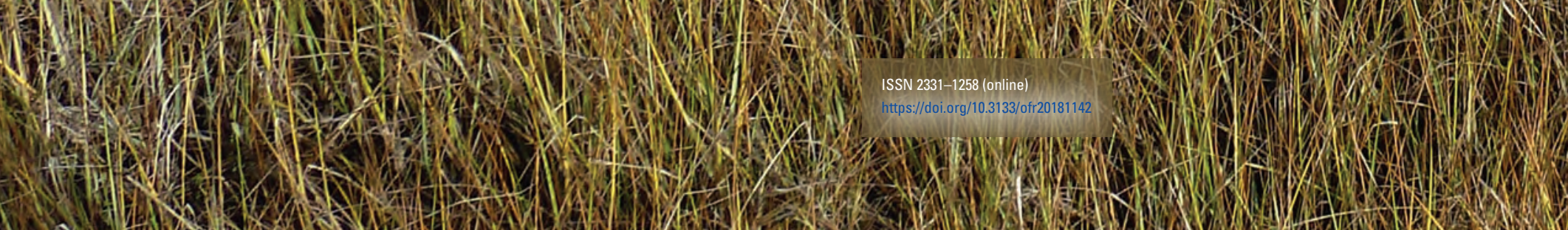

